\title{
ИНТРАМЕДУЛЛЯРНЫЕ ИМПЛАНТАТЫ ПРИ ЛЕЧЕНИИ ПЕРЕЛОМОВ ДЛИННЫХ ТРУБЧАТЫХ КОСТЕЙ И ИХ ПОСЛЕДСТВИЙ
}

\author{
Под редакцией д.м.н., профессора А.В.Попкова
}

Подготовлено при финансовой поддержке Российского научного фонда (проект №16-1500176) 
Попков А.В. Интрамедуллярные имплантаты при лечении переломов длинных трубчатых костей и их последствий. -, Deutschland : Palmarium Academic Publishing, 2016. - 225c.

Монография существенно дополняет сведения о возможности стимуляции репаративной регенерации тканей в травматологии, о реальном сокращении сроков консолидации перелома и реабилитации пациентов на основе остеоинтеграции имплантата с биоактивным покрытием. Подробно описан ряд новых медицинских технологий, раскрыты морфологические особенности репаративной регенерации кости при моделировании переломов диафиза длинных костей экспериментального животного и биомеханическая составляющая комбинированного остеосинтеза.

Предназначена прежде всего для травматологов-ортопедов, но может представлять интерес для инженеров-химиков, биомехаников, морфологов. 


\section{АВТОРСКИЙ КОЛЛЕКТИВ}

Попков Арнольд Васильевич - главный научный сотрудник Федерального государственного бюджетного учреждения «Российский научный центр «Восстановительная травматология и ортопедия» имени академика Г.А. Илизарова» Министерства здравоохранения Российской Федерации, доктор медицинских наук, профессор, травматолог-ортопед высшей категории. прошел путь от младшего научного сотрудника до заместителя директора по научной работе. С 1971 г. занимается проблемой удлинения и исправления деформаций верхних и нижних конечностей. В область постоянных интересов входят вопросы репаративной регенерации тканей, механизмы ее регуляции и ускорения, а также разработка и внедрение в практику травматологии и ортопедии нанотехнологий. Автор 13 монографий, более 300 научных публикаций, 38 изобретений. Под его руководством защищено 16 диссертаций.

Попков Дмитрий Арнольдович - доктор медицинских наук, заведующий научноклинической лабораторией «Коррекция деформаций и удлинение конечностей» Федерального государственного бюджетного учреждения «Российский научный центр «Восстановительная травматология и ортопедия» имени академика Г.А. Илизарова» Министерства здравоохранения и социального развития Российской Федерации, автор более 100 научных публикаций, 4 монографий, 18 патентов, касающихся решения многочисленных проблем ортопедического лечения патологии костно-мышечной системы у детей. Более четырех лет успешно работал врачом-ортопедом в детском ортопедическом центре г. Нанси (Франция), что позволило творчески объединить достижения отечественной ортопедии и стандарты западноевропейской медицины в формировании нового направления тканевой инженерии в травматологии и ортопедии.

Лунева Светлана Николаевна - доктор биологических наук, профессор, зав. научной лабораторией биохимии Федерального государственного бюджетного учреждения «Российский научный центр «Восстановительная травматология и ортопедия» имени академика Г.А. Илизарова» Министерства здравоохранения Российской Федерации. Автор 198 статей, 1 монографии, 26 патентов. Под ее руководством защищено 17 кандидатских и 3 докторских диссертации.

Шигарев Виниамин Максимович - кандидат медицинских наук, сотрудник Федерального государственного бюджетного учреждения «Российский научный центр «Восстановительная травматология и ортопедия» имени академика Г.А.Илизарова» Минздрава России, травматолог-ортопед высшей категории. Автор 18 изобретений и 25 рационализаторских предложений. Награжден знаком «Изобретатель СССР». Автор 108 научных публикаций. Научные исследования посвящены оптимизации лечебного процесса при лечении переломов костей в условиях чрескостного остеосинтеза аппаратом Илизарова.

Кононович Наталья Андреевна -ведущий научный сотрудник лаборатории коррекции деформаций и удлинения конечностей ФГБУ «Российский научный центр «Восстановительная травматология и ортопедия» имени академика Г.А. Илизарова» Министерства здравоохранения и социального развития Российской Федерации. Кандидат ветеринарных наук. Научная деятельность посвящена разработке моделей различных патологических состояний опорно-двигательного аппарата и способов их коррекции; изучению особенностей дистракционного остеогенеза при удлинении конечностей и замещении дефектов длинных костей в разных биомеханических условиях; поиску оптимальных условий, обеспечивающих благоприятное течение репаративных процессов в тканях поврежденного сегмента конечности. Автор 140 печатных работ и 6 патентов РФ.

Горбач Елена Николаевна - кандидат биологических наук по специальности «гистология, цитология, клеточная биология», ведущий научный сотрудник лаборатории морфологии сотрудник Федерального государственного бюджетного учреждения 
«Российский научный центр «Восстановительная травматология и ортопедия» имени академика Г.А.Илизарова» Минздрава России.

Автор 158 опубликованных печатных работ, 12 патентов на полезные модели и изобретения, трех монографий. Основное научное направление - изучение особенностей морфогенеза соединительных и опорных тканей в различных биомеханических условиях. Твердохлебов Сергей Иванович - кандидат физико-математических наук, работает в Национальном исследовательском Томском политехническом университете, доцент кафедры теоретической и экспериментальной физики. Область научно-практических интересов: покрытия, тонкие плёнки, медицинское материаловедение, матриксы для биоинженерии тканей, внедрение новых материалов и технологий в медицинскую практику: автор 14 патентов, 3 монографий, 55 статей

Больбасов Евгений Николаевич - инженер исследователь
кафедры Экспериментальной физики в Национальном исследовательском Томском политехническом университете. Область научных интересов - биоматериалы, композиты, поверхность матриксов для биоинженерии тканей, внедрение новых материалов и технологий в медицинскую практику. Автор 30 статей и 4 патентов.

Шестериков Евгений Викторович - канд. техн. наук, ведущий инженер в Федеральном государственном автономном образовательном учреждении высшего образования «Национальный исследовательский Томский политехнический университет». Область научных интересов - биоматериалы, композиты, внедрение новых материалов и технологий в медицинскую практику. Автор 20 статей и 2 патентов.

Коробейников Анатолий Анатольевич - врач травматолог-ортопед 1 категории, зав. отделением областной детской больницы «Красного креста» Курганской области. Область научных интересов - интрамедуллярный остеосинтез при переломах длинных трубчатых костей у детей.

Шелепов Алексей Викторович - врач травматолог-ортопед 1 категории, работает в травматологическом отделении политравмы городской больницы №2 г. Кургана. Область научных интересов - сочетанная травма, комбинированный остеосинтез длинных трубчатых костей при переломах плеча.

Мингазов Эдуард Рифович - врач травматолог-ортопед, после окончания Башкирского Государственного медицинского университета аспирант Федерального государственного бюджетного учреждения «Российский научный центр «Восстановительная травматология и ортопедия» имени академика Г.А. Илизарова» Министерства здравоохранения Российской Федерации. Область научных интересов - лечение детей с несовершенным остеогенезом, биомеханическое обоснование новых методов остеосинтеза. 


\section{ОГЛАВЛЕНИЕ}

СПИСОК АББРЕВИАТУР

ПРЕДИСЛОВИЕ 8

Глава 1 Современные аспекты проблемы лечения переломов длинных

трубчатых костей (Шигарев В.М., Попков А.В., Лунева С.Н.) 10

1.1. К Классификация переломов конечностей

1.1.1. Классификация диафизарных переломов костей конечности

1.2. Оперативные методы фиксации костей при переломах

1.3. Значение костного мозга в репаративном остеогенезе

1.4. Динамика восстановительных процессов при повреждениях конечности

Глава 2. Биосовместимые имплантаты в травматологии

(Попков Д.А., Твердохлебов С.И., Больбасов Е.Н., Шестериков Е.Н.)

2.1. Механизмы консолидации переломов

2.2. Методы нанесения кальций-фосфатных покрытий

2.2.1. Гибридный метод формирования биокомпозитов на поверхности

металлических имплантатов на основе микродугового оксидирования

2.2.2. Гибридный метод формирования многослойных покрытий на основе PVD технологий

2.2.3. Сигнето-электрическое полимерное покрытие металлических имплантатов

2.3. Тенденции развития биоимплантологии

Глава 3. Интрамедуллярное армирование - метод стимуляции репаративного остеогенеза

(Попков А.В., Горбач Е.Н., Кононович Н.А., Попков Д.А., Мингазов Э. Р., Больбасов Е.Н. )

3.1. Концепция остеогенеза на поверхности интрамедуллярного имплантата

3.2. Механические свойства покрытия

3.3. Морфологические особенности костеобразования вокруг интрамедуллярных имплантатов.

Глава 4. Интрамедуллярное армирование при лечении переломов длинных трубчатых костей

(Попков А.В.,Коробейников А.А., Попков Д.А., Шигарев В.М., Шелепов А.В.)

4.1. Общие принципы интрамедуллярного остеосинтеза

4.2. Остеосинтез диафизарных переломов бедренной кости

4.3. Остеосинтез чрезвертельных переломов бедренной кости

4.4 Остеосинтез диафизарных переломов костей голени

4.5. Остеосинтез диафизарных переломов плечевой кости

4.6. Остеосинтез диафизарных переломов костей предплечья 
Глава 5. Интрамедуллярное армирование при замедленной консолидации, ложных суставах и дефектах длинных трубчатых костей

(Попков А.В., Попков Д.А)

5.1. Общие принципы интрамедуллярного остеосинтеза

5.2. Монолокальный комбинированный компрессионный остеосинтез

5.3. Билокальный комбинированный компрессионно-дистракционный остеосинтез

5.4. Билокальный последовательный дистракционно-компрессионный остеосинтез с интрамедуллярным армированием

ЗАКЛЮЧЕНИЕ 198

СПИСОК ОСНОВНОЙ ЛИТЕРАТУРЫ 203 


\section{СПИСОК АББРЕВИАТУР}

ВМР - морфогенетический белок

$\mathrm{CaP}$ - кальций-фосфат (кальций-фосфатный, -ая, -ое, -ые)

FGF - фактор роста фибробластов

IGF - инсулиноподобный фактор роста

АВФ - аппарат внешней фиксации

АОС - антиоксидантная система

БФК - бифазная керамика

ВНСММ - вещества низкой и средней молекулярной массы

ВНСММ эр - вещества низкой и средней молекулярной массы в эритроцитах

ВНСММп - вещества низкой и средней молекулярной массы в плазме крови

ВСКП - высокоскоростное кислородное пламя

ГА - гидроксиапатит (гидроксиапатитовый, -ая, -ое, -ые)

ГАГ - гликозаминогликаны (сГАГ - сульфатированные гликозаминогликаны)

ГИМ - гемопоэзиндуцирующее микроокружение

ГИП - горячее изостатическое прессование

ДКМ - деминерализованный костный матрикс

ДТПА - диэтилентриаминпентауксусная кислота

ИЛО - импульсное лазерное осаждение

ИО - индекс остеосинтеза

ИТЖ - имитированная телесная жидкость

ИФ - индекс фиксации

КГА - карбонатсодержащий гидроксиапатит

КМП - костный морфогенетический протеин

$\mathrm{KOK}_{\phi}$ - колониеобразующая клетка фибробластов

КФ - кальцийфосфаты, кальцийфосфатные материалы

МП - минеральная плотность

МСМ - молекули средней массы

ОКФ - октакальцийфосфат

ОППИ - осаждение с помощью пучка ионов

ОЭН - осаждение электростатическим напылением

ПММА - полиметилметакрилат

ПОЛ - перикисное окисление липидов

ПХО - первичная хирургическая обработка

РФП - радиофармпрепарат

СГА - сфероидальный гидроксиапатит

СЭМ - сканирующая электронная микроскопия

ТКФ - трикальцийфосфат

ФДМ - функционально дифференцированный материал

ФДП - функционально дифференцированное покрытие

ФОП - физическое осаждение из пара

ХОП - химическое осаждение из пара

ЧО - чрескостный остеосинтез

ЭИ - эндогенная интоксикация

ЭОП - электронно-оптический преобразователь

ЭТС - эндогенные токсические субстанции 


\section{ПРЕДИСЛОВИЕ}

Ежегодно от травм в России страдает более 12 миллионов человек и в разных регионах показатели травматизма варьируют от 76 до 90 (на 1000 населения). Особое место среди причин травм занимает дорожно-транспортный травматизм, который с каждым годом приобретает все большее социальное и экономическое значение в связи с высокими показателями смертности (до 30000 в год), инвалидности и временной нетрудоспособности. Инвалидизация после травм в России в последние годы увеличилась с 46,7 до 56,9 \% (более 50 \% приходится на переломы костей конечностей). При этом полная реабилитация инвалидов снизилась с 20,9 до 15,4 \%. Эти цифры свидетельствуют прежде всего о несостоятельности общепринятых методов лечения и реабилитации, в которой нуждаются до 98 \% инвалидов после травм [Попова Л.А., 1993].

Экономическая составляющая траматизма определяется сроками временной нетрудоспособности при переломах костей, которые остаются неизменными более 100 лет несмотря на развитие хирургии, анестезиологии, технологии остеосинтеза. Поэтому мировая наука наряду с изучением оптимальных условий для репаративной регенерации ищет способы стимуляции восстановительных процессов в поврежденных тканях. Чаще всего для этого предлагают аутотрансплантаты костной ткани и различные биоактивные изделия из декальцинированной кости, биокомпозиционных матриксов, рекомбинантных костных морфогенетических белков, а также из керамики; расширяются экспериментальные исследования с использованием клеточных технологий [Баринов С.М., 2010; Миронов С.П. и др., 2010]. Однако до настоящего времени полученные результаты либо далеки от клинического применения, либо мало что изменили в процессе репаративной регенерации, а, следовательно, сроках лечения.

В настоящей работе предпринята попытка обобщить с точки зрения практикующего травматолога-ортопеда результаты исследований и разработок биоактивных имплантатов, имеющих перспективу клинического использования. Поскольку к основным критериям качества материалов для имплантатов наряду с биологической совместимостью относится

также близость механических свойств, то в книге представлены биомеханические 
исследования, отражающие изменения параметров остеосинтеза при управлении ростом массы костной ткани.

Большая часть монографии отдана изложению клинического материала и новым технологиям стимуляции репаративного остеогенеза, которые наиболее широко используются в клинике ФГБУ «Российский научный центр «Восстановительная травматология и ортопедия» имени академика Г.А. Илизарова» (г. Курган). Подробно разработаны клинические технологии для лечения переломов длинных трубчатых костей, посттравматических ложных суставов и дефектов, для оперативного удлинения конечностей. Использование методов стимуляции, основанных на интрамедуллярном внедрении имплантатов с керамическим наногидроксиапатитовым покрытием, позволило гарантировать положительный результат лечения и реальное сокращение сроков остеосинтеза при переломах костей, в 2-4 раза. Простота, доступность и экономическая целесообразность использования на самых ранних этапах медицинской эвакуации (районная больница) особенно важны в период перехода Российской федерации на систему обязательного медицинского страхования. Новые технологии легко вписываются в объем базовой травматологической помощи и, помощи, осуществляемой по срочным показаниям и в плановом порядке при восстановительном лечении последствий и осложнений травмы, финансируемой из фондов ОМС.

Авторы выражают признательность всем сотрудникам ФГБУ «РНЦ «ВТО» им. акад. Г.А. Илизарова», прежде всего организационно-методического отдела Смирновой И.Л. и Борзуновой О.Б., и Национального исследовательского Томского политехнического университета за деятельное участие в подготовке книги. 


\section{ГЛАВА 1 \\ СОВРЕМЕННЫЕ АСПЕКТЫ ПРОБЛЕМЫ ЛЕЧЕНИЯ ПЕРЕЛОМОВ ДЛИННЫХ ТРУБЧАТЫХ КОСТЕЙ}

Травматизм, совокупность травм у определённых групп населения за определённый период времени; важный показатель влияния социальных условий жизни на состояние здоровья населения. При изучении травматизма учитываются вновь возникшие травмы. В XX в. травматизм занял третье после опухолевых и сердечнососудистых заболеваний место в структуре смертности в экономически развитых странах. Уровень травматизма в Российской Федерации в среднем за последние 30 лет достиг $872 \pm 6,3$ случая на 10 тысяч человек и не имеет тенденции к снижению показателей [Кувакин В.И., 2013; Тихилов Р.М. с соавт., 2012]. Ежегодно в Российской Федерации свыше 13 миллионов человек получают травмы, среди которых 20-25\% - с политравмой, летальность при которой достигает 30\%. Тяжесть перенесенных травм, в первую очередь, предопределяет срывы восстановительных процессов, приводит к стойкой утрате трудоспособности и снижению качества жизни пострадавших. В Российской Федерации последствия травм среди причин первичной инвалидности, занимают третье место после онкологических и сердечно-сосудистых заболеваний (Ахметьянов Р.Ф., 2005; Купкенов Д.Э., 2010; Татарников М.А., 2006), а у граждан трудоспособного возраста выходят на первое место, имея при этом в последние годы тенденцию к устойчивому росту (Андреева T.М., 2010; Татарников М.А., 2006; Ханапияев У.Б., 2000).

В целом среди инвалидов после травм более 50\% составляют люди моложе 45 лет. Различают травматизм производственный (промышленный и сельскохозяйственный) и непроизводственный (бытовой, транспортный, спортивный и др.).

Сама по себе травма - это нарушение нормального состояния ткани или органа. Повреждение или нарушение целостности ткани. В нашем случае - это повреждение кости, мышцы, кожи и пр.

Кость - это прежде всего опорная ткань, которая призвана сохранить форму тела, выдержать гравитационную нагрузку и обеспечить передвижение как отдельных частей тела, так и всего организма в пространстве. Поэтому травматизм неразрывно связан с проблемой лечения, с перечнем способов лечения, сроком лечения и исходами этого лечения.

При неудачном стечении обстоятельств лечение заканчивается инвалидностью, т.к. не все методы лечения достигают положительного результата. Инвалидизация 
работающих в возрасте до 45 лет в большей степени обусловлена тяжестью полученных повреждений и качеством оказания медицинской помощи.

Тяжесть полученных повреждений определяет возникновение различных осложнений и последствий травм, ведущих к инвалидизации. Чаще всего это нарушения со стороны центральной нервной системы и периферических нервных стволов $(31,7 \%)$, несросшиеся переломы костей $(21.3 \%)$, ложные суставы $(8,8 \%)$ и др.

Несомненно, что дефекты лечебной и диагностической помощи напрямую определяют первичную инвалидизацию: дефекты диагностики отмечены у 15,6\%, тактические ошибки - у 21,6\%, ошибки консервативного лечения - 18,5\%, оперативного лечения - 12,0\%, физио-функционального - у 12,0\% [Росков Р.В., Андриевская А.О., Смирнов А.В.,2009].

Наибольшую группу инвалидов среди пострадавших от травм составляют больные с переломами конечностей - 67,9\%. Из этого контингента $30 \%$ лечились только консервативно, а 70\% - оперативно. При лечении последних наиболее часто использовались следующие виды остеосинтеза: чрескостный остеосинтез различными аппаратами внешней фиксации - 36,8\%; внутрикостный - 26,3\%; накостный остеосинтез $13.2 \%$; остеосинтез винтами - 10,5\%; остеосинтез диафиксирующими спицами - 10,5\%.

И.В.Шведовченко с соавторами на IX съезде травматологов-ортопедов России отметил ряд причин инвалидности после травм: тяжесть патологии 95,2\%, низкое качество диспансеризации 65,5\%, позднее выявление инвалидизирующего заболевания и травмы 51,2\%, недостатки амбулаторного лечения 33,3\%, недостатки стационарного лечения больных и инвалидов 14,6\% [Шведовченко И.В. с соавт., 2010].

\section{1. Классификация переломов конечностей}

Переломом называется полное или частичное нарушение целости кости, возникающие под влиянием травмирующего агента или при изменениях в костной ткани вследствие болезни (остеомиелит, туберкулез, злокачественные опухоли). В зависимости от локализации перелома в пределах трубчатой кости переломы делятся на эпифизарные, метафизарные и диафизарные. Наиболее частыми являются диафизарные, реже бывают эпифизарные и метафизарные. Эпифизарные переломы (внутрисуставные) являются наиболее тяжелыми, они ведут к смещениям суставных концов костей и вывихам, вследствие чего нарушается конфигурация сустава.

Метафизарные переломы (околосуставные) в результате сцепления одного отломка с другим, чаще бывают без смещения и называются вколоченными. 
Переломы диафизарного отдела кости могут быть одинарные, когда имеется два отломка, двойные (имеется три отломка - верхний, средний и нижний). В зависимости от направления линии излома к длинной оси кости различают переломы:

а) поперечные, если плоскость перелома идёт поперечно, образуя прямой угол с осью диафиза кости. Эти переломы чаще возникают в результате прямой травмы, особенно у детей;

б) при косых переломах, как правило, плоскость излома идёт не под прямым углом, а под косым;

в) винтообразные или спиральные переломы диагносцируют, если механизм травмы связан со скручиванием кости вокруг своей оси. Поверхность перелома идёт спирально, образуя на одном отломке заострённый край, а на другом - соответствующую впадину;

г) нередко при переломах образуются осколки, такой перелом получил название оскольчатого, а по количеству осколков переломы называются однооскольчатые и многооскольчатые.

Любой перелом характеризуется тем, что положение костных отломков может значительно отличаться в результате их смещения. Под смещением отломков понимается любое отклонение образовавшихся фрагментов кости от того положения, которое они занимали до повреждения.

Существует несколько видов смещения отломков: по ширине, по длине, под углом, ротационное или торсионное (по периферии), когда периферический отдел конечности повёрнут вокруг собственной оси кнутри или кнаружи (Рис.1.1).

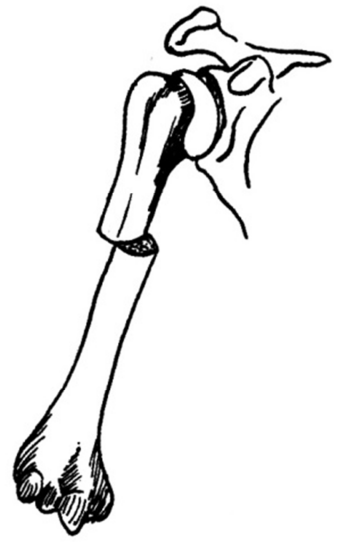

a

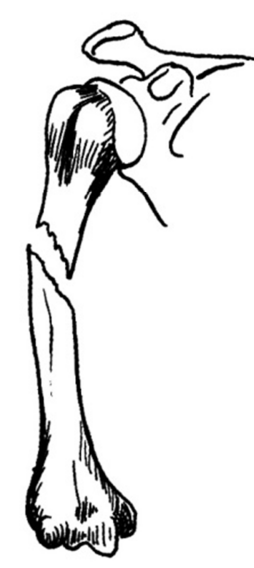

6

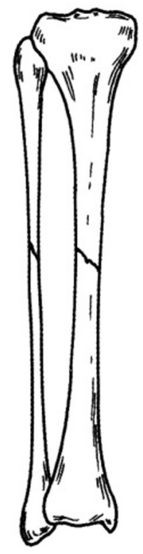

B

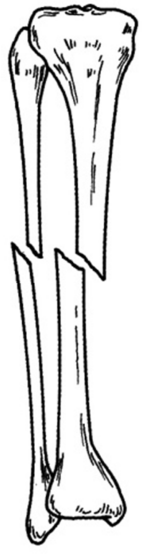

$\Gamma$

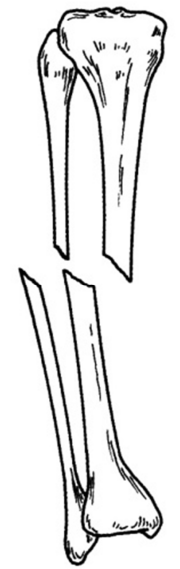

д

Рис. 1.1. Некоторые виды смещения отломков: а - перелом диафиза плечевой кости со смещением по ширине; б - перелом диафиза плечевой кости со смещением под углом; в - косой перелом диафизов большеберцовой и малоберцовой костей без смещения; г - перелом диафизов большеберцовой и малоберцовой костей с частичным смещением отломков по ширине, когда контакт между отломками еще сохранен; д - перелом диафизов большеберцовой и малоберцовой костей с полным смещением отломков. 
Учитывая многообразие переломов, их возникновение, характер излома, локализацию, смещение костных отломков, а также другие характеристики, необходима систематизация этих данных в виде классификации переломов. Она позволит выработать оптимальную тактику лечения, изучить отдалённые результаты и выработать необходимые рекомендации.

Одной из востребованных классификаций переломов является универсальная классификация AO/ASIF, предложенная швейцарской ассоциацией травматологовортопедов. Она весьма детализирована и кроме основных сегментов скелета рассматривает позвоночник, таз, кисть и стопу. Наиболее приемлемой классификацией при диафизарных переломах длинных костей мы считаем классификацию, предложенную Ключевским В.В. (2004г.).

\subsection{1. Классификация диафизарных переломов костей конечности}

Переломы диафиза плечевой кости. Переломы диафиза плечевой кости могут быть поперечными, косыми и винтообразными (Рис.1.2). Они также бывают оскольчатыми и двойными (множественными). Смещение отломков зависит от механизма повреждения и от тяги мышц. Если линия перелома находится выше прикрепления дельтовидной мышцы, центральный отломок под действием мышц, прикрепляющихся к большому бугру, отводится и ротируется кнаружи, а дистальный приводится к туловищу, ротируется кнутри и смещается кверху. При переломе в средней трети, ниже прикрепления дельтовидной мышцы, под ее действием центральный отломок отводится, а дистальный подтягивается кверху. Между отломками возникает угловая деформация с углом, открытым кнутри. При переломах плечевой кости в средней и нижней третях необходимо обратить внимание на состояние лучевого нерва, который на этом уровне соприкасается с костью и может быть травмирован отломками.

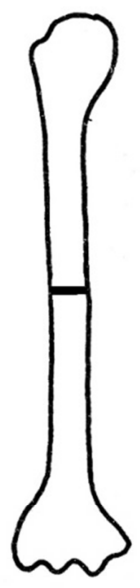

a

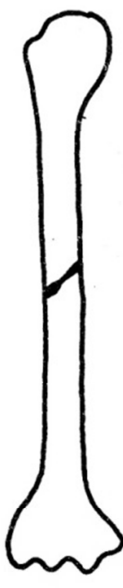

6

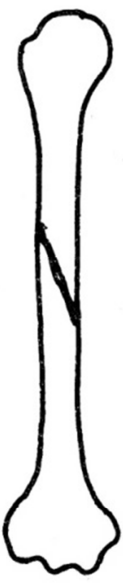

B

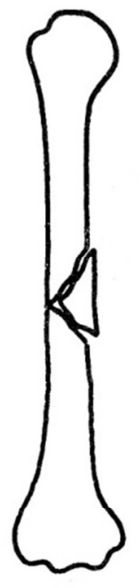

$\Gamma$

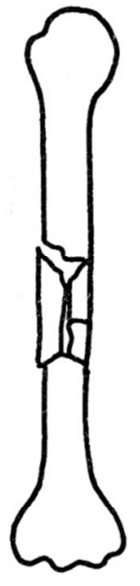

д

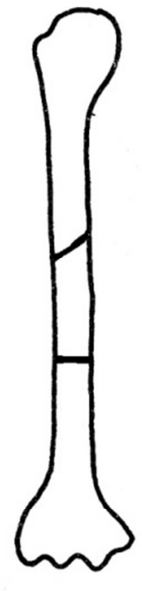

e

Рис. 1.2. Переломы диафиза плечевой кости: а) поперечный; б) косой; в) винтообразный; г) оскольчатый; д) многоооскольчатый; е) двойной. 
Переломы диафизарного отдела костей предплечья. Среди диафизарных переломов костей предплечья наблюдаются: изолированный перелом одной кости (Рис.1.3), перелом обеих костей, перелом локтевой кости с одновременным вывихом головки лучевой кости (перелом Монтеджа), перелом лучевой кости на границе средней и нижней трети с одновременным вывихом дистального конца локтевой кости (перелом Галеацци).

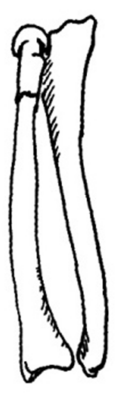

a

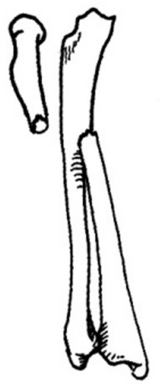

6

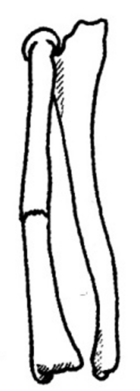

B

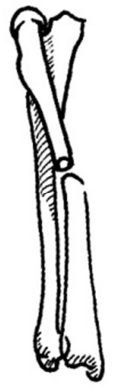

$\Gamma$

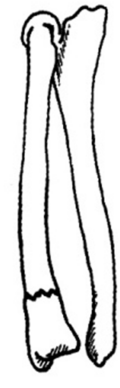

Д

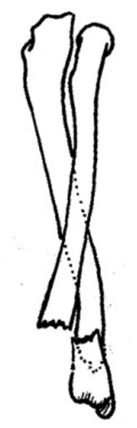

e

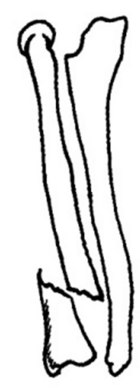

ж

Рис. 1.3. Некоторые виды переломов диафиза лучевой кости: а- перелом верхней трети диафиза лучевой кости без смещения; б - перелом верхней трети диафиза лучевой кости со смещением; в - перелом средней трети диафиза лучевой кости без смещения; г - перелом средней трети диафиза лучевой кости со смещением; д - перелом нижней трети диафиза лучевой кости без смещения; е - перелом нижней трети диафиза лучевой кости со смещением; ж - перелом Галеацци.

Чаще на уровне диафиза бывают переломы обеих костей предплечья (Рис.1.4), причем обе кости обычно ломаются на одном уровне. Эти переломы могут быть простыми (поперечные, косые, винтообразные), оскольчатыми и многооскольчатыми.

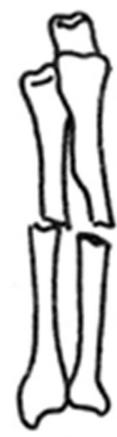

a

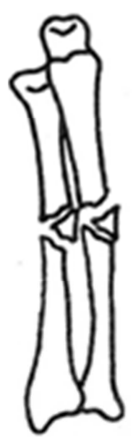

6

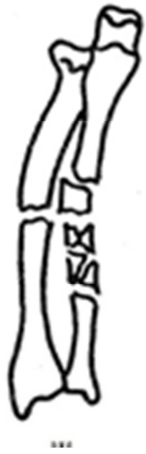

B

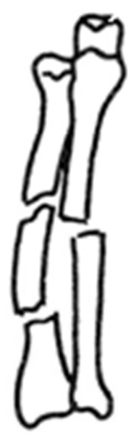

$\Gamma$

Рис. 1.4. Переломы в области диафиза костей предплечья: а - поперечный перелом обеих костей предплечья на уровне средней трети; б - оскольчатый перелом обеих костей предплечья; в - поперечный перелом лучевой кости и многооскольчатый перелом локтевой; г - двойной перелом лучевой и поперечный перелом локтевой кости.

При переломах костей предплечья нарушаются как пронация, так и супинация кисти. Как правило, серьезно страдает ротационная функция предплечья при переломе 
лучевой кости, т.к. она принимает активное участие в пронации и супинации. Переломы только одной локтевой кости встречаются реже, чем лучевой, при этом возникает смещение только по длине и ширине. Эти переломы меньше влияют на функцию предплечья.

Переломы диафиза бедренной кости. Бедренная кость - самая крупная и наиболее прочная кость скелета человека. Её анатомическая конструкция достаточно сложна. Три уровня переломов диафиза бедра имеют свои характерные особенности и требуют специфического подхода в лечебной тактике в зависимости от уровня повреждения.

При переломах верхней трети бедренной кости наблюдается характерное смещение проксимального отломка кпереди и кнаружи с наружной ротацией в результате ретракции ягодичных мышц. Переломы средней трети бедра характеризуются разнообразием смещения костных отломков. Они большей частью определяются особенностью механизма травмы и могут иметь все виды смещений: по длине, ширине, под углом и по периферии. При переломах в нижней трети бедренной кости, дистальный отломок под действием тяги икроножной мышцы смещается кзади. Он может сдавливать сосудистонервный пучок и вызывать ишемию конечности. Переломы диафиза бедренной кости по направлению линии излома могут быть поперечными, косыми, винтообразными (Рис.1.5ав). Все они могут быть оскольчатыми, многооскольчатыми и фрагментарными (Рис.1.5гe).

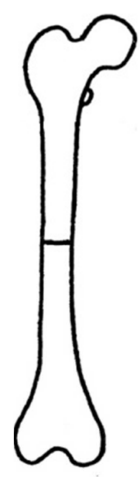

a

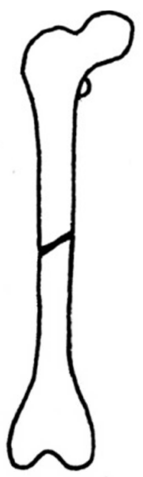

6

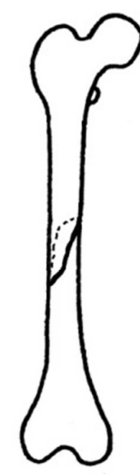

в

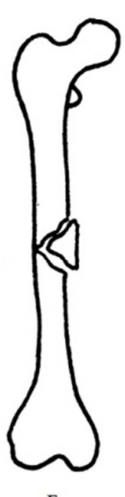

г

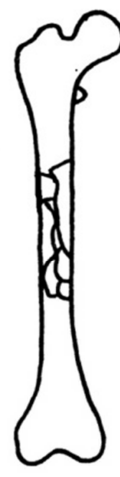

д

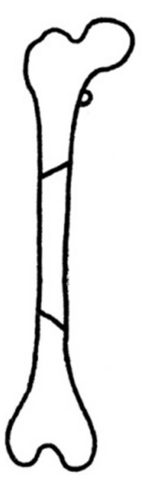

e

Рис. 1.5. Диафизарные переломы бедренной кости: а) поперечный; б) косой; в) винтообразный (спиральный); г) оскольчатый; д) многооскольчатый; е) двойной (множественный).

Переломы диафизарного отдела костей голени. В клинической практике, среди всех переломов длинных костей, наиболее часто встречаются диафизарные переломы голени. Механизм травмы, ведущей к возникновению переломов голени разнообразен и часто соответствует характеру этих переломов. При прямом ударе возникают поперечные и крупнооскольчатые (бамперные) переломы. При резком развороте корпуса, при фиксированном положении одного из концов кости, в результате скручивания, возникает 
винтообразный (спиральный) перелом. Величина площади перелома при винтообразных и косых переломах кости, а также при многооскольчатых переломах способствует интерпозиции мягкими тканями и костными отломками. Репозиция отломков усложняется не только характером перелома, но и особенностью смещений. В верхней трети проксимальный отломок в результате тяги четырехглавой мышцы смещается кпереди. В средней или нижней трети, где чаще происходят винтообразные переломы, смещение происходит по оси, при этом малоберцовая кость иногда ломается непосредственно у головки, что может вызвать повреждение малоберцового нерва, который располагается на этом уровне. При большой кинетической энергии травмирующего агента, которая может превышать прочность костной ткани человеческого скелета, могут наблюдаться двойные и тройные переломы диафизарного отдела голени (Рис.1.6).

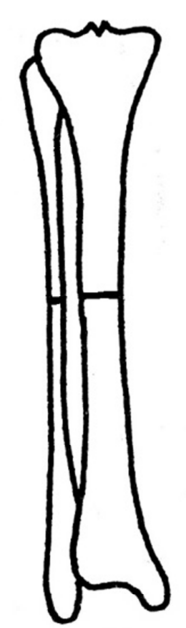

a

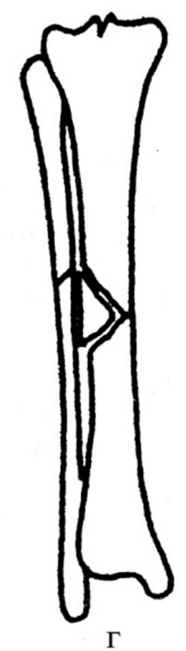

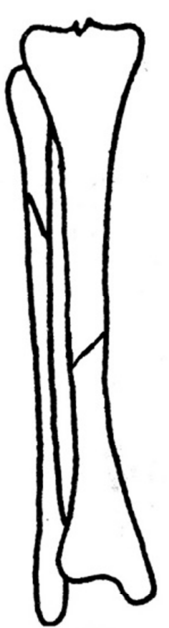

6

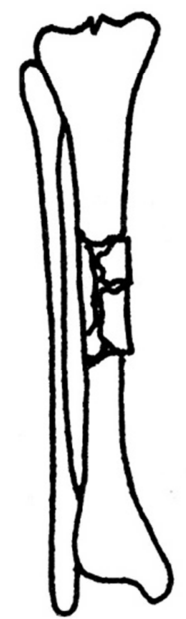

Д

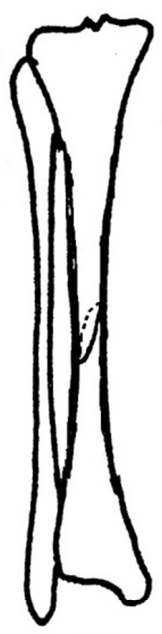

B

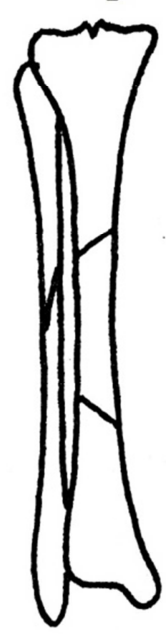

e

Рис. 1.6. Переломы диафизарного отдела голени: а) поперечный; б) косой; в) винтообразный; г) оскольчатый; д) многооскольчатый; е) двойной.

Как мы убедились в основе многих причин инвалидизации пациентов после травм лежат врачебные ошибки при диагностики заболевания и тактические ошибки в выборе 
метода лечения. Преодолеть подобные причины осложнений переломов призваны тщательное исследование пациента, знания механизмов травмы и оптимальный выбор используемой классификации повреждений.

Переломы, как изолированные, так и в составе политравмы, могут привести к тяжелым осложнениям, часто зависящим не столько от перелома, сколько от сопутствующих повреждений мягких тканей. Tscherne (1983) считал, что тяжесть травмы в основном зависит от степени повреждения мягких тканей. Как при закрытых, так и при открытых переломах (Таблица 1.1). В основу ганноверской классификации тяжести повреждений мягких тканей положены именно принципы Tscherne J.

Таблица 1.1. Ганноверская классификация тяжести повреждения мягких тканей [Oestern H. J.,Tscherne H., 1983]

\begin{tabular}{|c|l|}
\hline Степень & \multicolumn{1}{|c|}{ Описание } \\
\hline 0 & $\begin{array}{l}\text { Повреждение мягких тканей отсутствует, непрямой механизм травмы, простая } \\
\text { модель перелома. }\end{array}$ \\
\hline I & $\begin{array}{l}\text { Поверхностная рана кожи, ушиб мягких тканей за счет внутреннего сдавления } \\
\text { костными отломками }\end{array}$ \\
\hline II & $\begin{array}{l}\text { Выраженное загрязнение мягких тканей, ушиб кожных покровов за счет } \\
\text { прямого механизма травмы, угроза развития подфасциального } \\
\text { гипертензионного синдрома, сложная модель перелома. }\end{array}$ \\
\hline III & $\begin{array}{l}\text { Тяжелый ушиб мягких тканей с некрозом кожи, мионекрозом, скальпированная } \\
\text { рана, острые проявления подфасциального гипертензионнного синдрома, } \\
\text { модель оскольчатого перелома }\end{array}$ \\
\hline
\end{tabular}

Систематизация открытых переломов по степени тяжести было предложено достаточно много, но чаще всего популярностью пользуется классификация R.B. Gustilo (Таблица 1.2 ).

Таблица 1.2. Классификация открытых переломов [Gustilo R.B. et al., 1984].

\begin{tabular}{|c|l|}
\hline Степень & \multicolumn{1}{|c|}{ Описание } \\
\hline I & $\begin{array}{l}\text { Чистая рана менее 1 см, сквозное ранение, отсутствие или небольшое загрязнение } \\
\text { раны, простая модель перелома }\end{array}$ \\
\hline II & $\begin{array}{l}\text { Скальпированная рана кожи менее 1 см, отсутствие следов ушиба в окружности } \\
\text { раны, жизнеспособная мышечная ткань, умеренная неустойчивость по сравнению } \\
\text { с тяжелым переломом }\end{array}$ \\
\hline III & Обширные повреждения мягких тканей, загрязненная рана, скелетированная \\
\hline
\end{tabular}




\begin{tabular}{|c|l|}
\hline & $\begin{array}{l}\text { кость, заметная неустойчивость из-за раздробленного перелома или } \\
\text { сегментарного дефекта кости }\end{array}$ \\
\hline IIIA & Сломанная кость практически полностью закрыта мягкими тканями \\
\hline IIIB & Скелетированная кость с повреждением надкостницы \\
\hline IIIC & $\begin{array}{l}\text { Любой открытый перелом, сопровождающийся повреждением артериального } \\
\text { сосуда с необходимостью его реконструкции }\end{array}$ \\
\hline
\end{tabular}

\section{2. Оперативные методы фиксации костей при переломах}

В данной работе мы не касаемся методов консервативного лечения переломов костей. С середины XX столетия развиваются в основном способы оперативной фиксации костных отломков методами накостного остеосинтеза, внутрикостного остеосинтеза и чрескостного остеосинтеза аппаратами внешней фиксации (АВФ). Несомненно, прежде чем остановиться на том или ином методе оперативного остеосинтеза травматолог должен оценить общее состояние пациента, влияние тяжести травмы и предстоящего оперативного вмешательства, возраста и состояния костей у пострадавшего. Последнее является определяющим для выбора вида остеосинтеза, поэтому следует иметь представление о строении кости как на органном, так и на тканевом, и даже на клеточном уровне.

С гистологической точки зрения у человека существуют два основных типа костной ткани: грубоволокнистая (ретикулофиброзная) и пластинчатая. В пластинчатой костной ткани коллагеновые волокна располагаются параллельными слоями (костные пластинки) и легко различимы при поляризационной микроскопии. Пластинчатая костная ткань образует компактное и губчатое вещество костей скелета. Например, в длинных костях компактное костное вещество формирует диафиз кости и покрывает ее метафиз, окружая костномозговую полость, в которой содержатся, губчатое вещество кости, костный мозг и жировая ткань.

Соответственно анатомо-функциональному строению в каждой трубчатой кости различаются следующие части (Рис.1.7): 


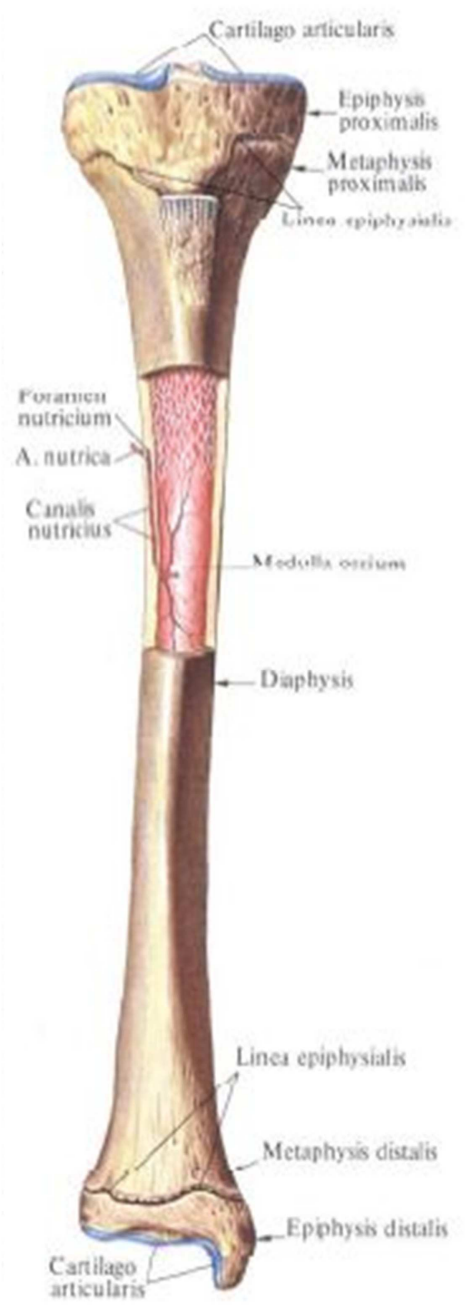

Рис. 1.7. Анатомическое строение длинной трубчатой кости на примере большеберцовой.

1. Тело кости, диафиз, представляющий собой костную трубку, содержащую у взрослых желтый костный мозг и выполняющую преимущественно функции опоры, защиты и движения (рычаги). Стенка трубки состоит из плотного компактного вещества, substantia compacta, в котором костные пластинки расположены очень близко друг к другу и образуют плотную массу. Компактное вещество диафиза разделяется на два слоя соответственно окостенению двоякого рода: 1) наружный, кортикальный, слой, возникающий путем перихондрального окостенения из надхрящницы или надкостницы, откуда и получает питающие его кровеносные сосуды; 2) внутренний слой, возникающий путем эндохондрального окостенения и получающий питание от сосудов костного мозга.

Концы диафиза, прилегающие к эпифизарному хрящу, называются метафизами. Они развиваются вместе с диафизом, но участвуют в росте костей в длину и состоят из губчатого вещества, substantia spongiosa. В ячейках «костной губки» находится красный костный мозг.

2. Суставные концы каждой трубчатой кости, расположенные по другую сторону эпифизарного хряща, - эпифизы. Они также состоят из губчатого вещества, содержащего 
красный костный мозг, но развиваются, в отличие от метафизов, эндохондрально из самостоятельной точки окостенения, закладывающейся в центре хряща эпифиза; снаружи у них имеется суставная поверхность, участвующая в образовании сустава.

3. Расположенные вблизи эпифиза костные выступы - апофизы, к которым прикрепляются мышцы и связки. Апофизы окостеневают эндохондрально из самостоятельно заложенных в их хряще точек окостенения и построены из губчатого вещества.

Костный скелет выполняет в целом ряд функций, имеющих механическое и биологическое значение. Механическая функция скелета проявляется в осуществлении опороспособности, движения и защиты. Биологическая функция костной системы определяется ее участием в процессах кроветворения и обмена веществ.

С точки зрения механики кость - это композитный материал, состоящий из минерала, коллагена, неколлагеновых протеинов, других органических веществ и воды. Это одна из ряда минерализованных тканей позвоночных, которая использует в качестве минерала некоторые разновидности фосфата кальция (гидроксиапатит), единичная ячейка которого содержит $\mathrm{Ca}_{10}\left(\mathrm{PO}_{4}\right)_{6}(\mathrm{OH})_{2}$. Форма кристаллов гидроксиапатита (ГА) до настоящего времени вызывает споры у исследователей. Однако все они единодушны в том, что поперечные размеры кристалла обычно составляют 40 нм, но иногда не превышают 5 нм. Продольные размеры менее стабильны - длина составляет по меньшей мере 50 нм, и считается, что кристаллы могут расти именно в этом направлении, пока не достигнут нескольких сотен нанометров [Ziv V., Weiner S., 1994].

Костная система принимает непосредственное участие в обмене веществ: минеральном, белковом, обмене микроэлементами. В скелете сосредоточено около $99 \%$ тканевого кальция, 87 \% фосфора, 58 \% магния и др. Минеральная часть кости представляет собой систему с огромной поверхностью, находящуюся в постоянном контакте с окружающей тканевой жидкостью. Благодаря малым размерам кристаллов гидроксиапатита и особенностям его строения происходит быстрый обмен ионов. Органический материал кости на 90 \% массы состоит из коллагена типа 1. Другие органические материалы - это различные неколлагеновые протеины и гликопротеины. Функция этих органических соединений составляет предмет интенсивных исследований. Некоторые из них играют огромную роль в процессе репаративной регенерации и ремоделирования кости; например, костный морфогенетический протеин участвует в инициировании и управлении минерализацией, а гликопротеин необходим для определения мест ядрообразования апатита. 
Компактное вещество - это основная гистологическая структура, если рассматривать механические возможности кости, ее прочностные свойства. Состоит из остеонов, или гаверсовых систем. Остеоны на поперечном срезе (рис. 1.8) имеют форму круга или овала и содержат кровеносные сосуды. Последние окружены концентрически ориентированными костными пластинками и в основном располагаются в продольном направлении, редкие ответвления соединяют их с соседними гаверсовыми системами. Остеоциты располагаются концентрически вокруг центрального канала параллельно пластинкам и связаны тонкими канальцами, содержащими отростки цитоплазмы остеоцитов. Между остеонами видны области пластинчатой костной ткани с неправильным строением - интерстициальные пластинки. Это остатки ранее сформированных гаверсовых систем, разрушенных в процессе реконструкции, непрерывно протекающем в кортикальном слое кости.

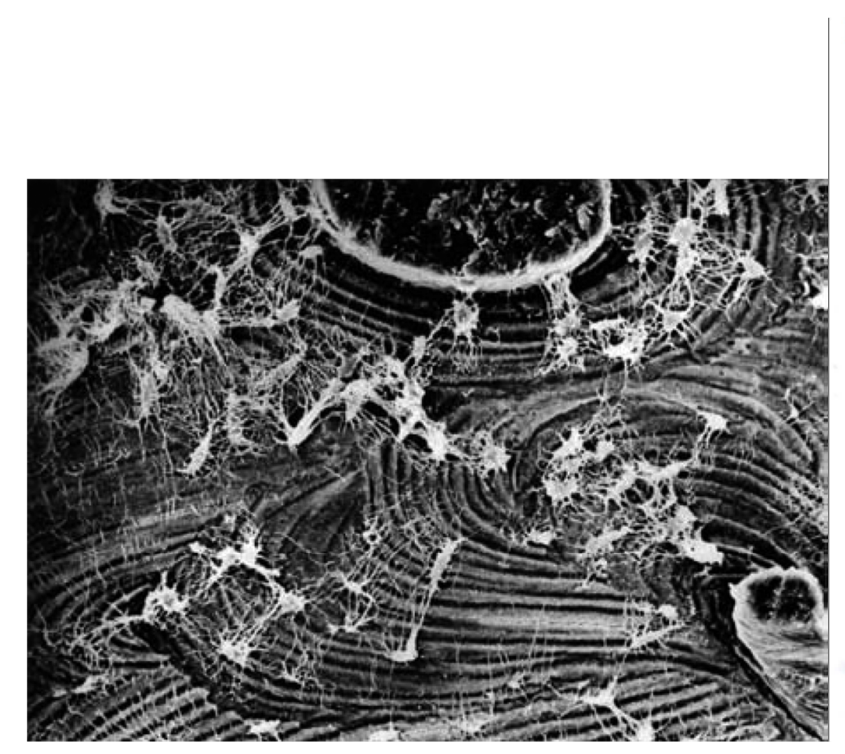

a

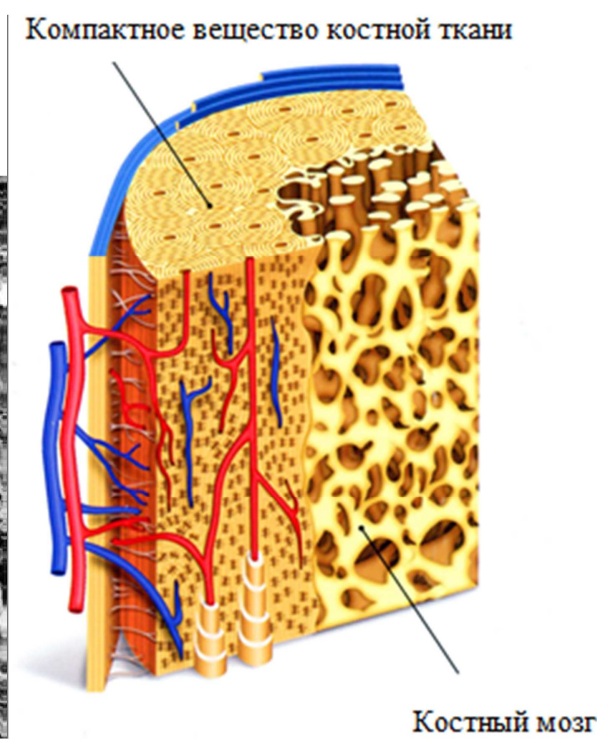

B

Рис. 1.8. Гаверсова система компактного вещества кости: а - сканирующая электронная микрофотография поперечного среза. Ширина поля зрения около 200 мкм [Currey J.D., 2002]; в - схема строения диафизарной части длинной трубчатой кости.

Губчатое вещество состоит из ряда взаимосвязанных костных трабекул, каждая из которых имеет большое количество отверстий и перегородок (рис. 1.9). Кость не образует замкнутых ячеек, поэтому непосредственно связана с костным мозгом. 


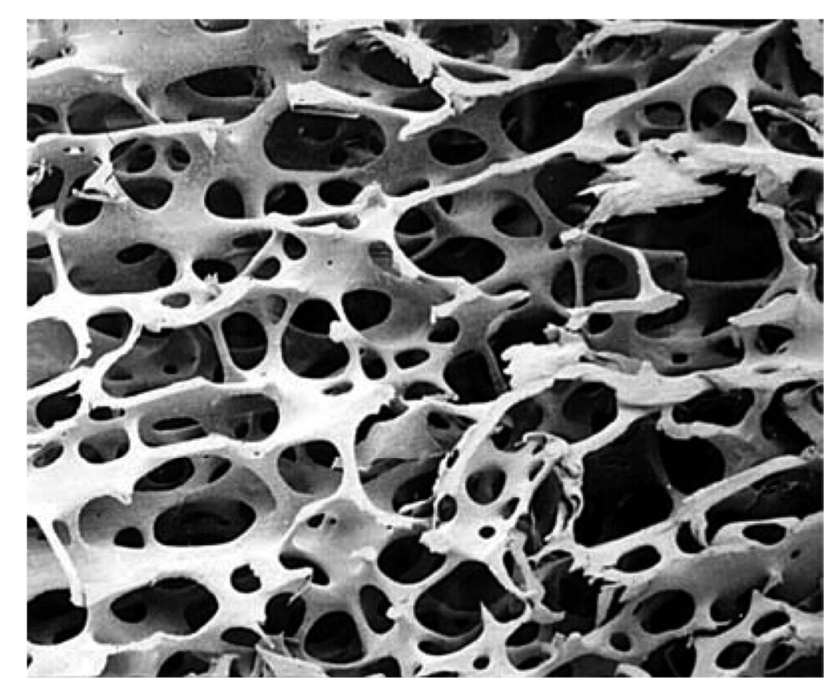

Рис. 1.9. Губчатое вещество кости: кость и промежутки (заполненные при жизни костным мозгом) взаимосвязаны.

С точки зрения биологической активности губчатое вещество с его огромной площадью поверхности, с популяциями клеток на этой поверхности, обильным кровоснабжением и непосредственным контактом с костным мозгом отличает относительно более высокий уровень обменных процессов. С другой стороны, такое строение обеспечивает механическую прочность кости при относительно небольшой массе. Тем не менее, по-видимому, оно имеет несколько пониженное содержание минерала, следовательно, модуль Юнга и прочность также ниже, чем у обычной кости [Guo X.E., Goldstein S.A., 1997; Bayrakter H.H. et al., 2004]. Однако различие в механических свойствах между компактным и губчатым веществом определяется гораздо бо́льшим количеством последнего на единицу объема, чем механическими свойствами материала самой губчатой кости. Поскольку оптическая плотность губчатой кости обычно около 10-20\%, это подразумевает, что при сравнении с компактной ее жесткость и прочность около 1-4 \%. Любые различия в свойствах материала несущественны по сравнению с различиями в оптической плотности [Day J.S. et al., 2004]. Также важен характер расположения костных трабекул. Если они ориентированы преимущественно в одном направлении, кость будет жестче и прочнее именно в этом направлении, чем под большими углами к ней.

Хирургия переломов костей. Механические, прочностные свойства компактного и губчатого вещества костей, как правило, определяют выбор тактики лечения перелома и метод остеосинтез. Хирургия переломов всегда была похожа на ремесло, но именно этой части хирургии в большей степени принадлежит стремление к восстановлению биологического и физиологического равновесия вслед за повреждением. Как нигде в другой области медицины успех в лечении переломов зависит от качества и количества первичного материала костной ткани, ее кровоснабжения и регенераторных потенциалов. 
Хирургия костей создавалась и эволюционировала в содружестве с биологией, имплантологией, металловедением, а также в условиях жестких и непредсказуемых законов биомеханики.

Бельгиец Lambotte считается «отцом» современной внутренней фиксации, принципы которой продолжил развивать его соотечественник Danis, который утверждал, что жесткая фиксация должна приводить к первичному сращению без формирования костной мозоли [W. R. Smith, P. F. Stahel, S. J. Morgan, P. G. Trafton ,2013]. В 1958 г. группой швейцарских хирургов была основана международная ассоциация по проблемам остеосинтеза (AO/ASIF). Несколько раньше в России появился надежный аппарат внешней фиксации (аппарат Илизарова), на основе которого развились технологии закрытой репозиции и надежной фиксации костных фрагментов: снизилась травматичность оперативного вмешательства, практически не повреждался костный мозг, впервые появилась возможность функциональной нагрузки с первого дня после операции. Нужно отметить, что и развитие внутреннего (погружного) остеосинтеза, особенно в настоящее время старается утверждать концепцию стабильной фиксации, бережного отношения к мягким тканям, ранней активизации и функциональной реабилитации [Helfet D.L. et al., 2003; Perren S.M., Matter P., 2003]. Фиксаторы для погружного остеосинтеза изготавливают из биологически и химически инертных материалов - специальных сплавов, содержащих никель, кобальт, хром или титан. Имплантация в ткани фиксаторов из указанных материалов практически не вызывает развития металлоза (поглощения клетками соединительной ткани микрочастиц металла), который наблюдается при использовании погружных фиксаторов из нержавеющей стали. После сращения перелома металлические фиксаторы удаляют.

Противопоказаниями к погружному остеосинтезу являются открытые переломы костей конечностей с большой зоной повреждения или загрязнением мягких тканей, местный или общий инфекционный процесс, общее тяжелое состояние, тяжелые сопутствующие заболевания внутренних органов, выраженный остеопороз, декомпенсированная сосудистая недостаточность конечностей.

Наружный чрескостный остеосинтез в мировой практике имеет меньше противопоказаний: алкоголизм, эпилепсия, психические заболевания, декомпенсированная лимфовенозная недостаточность конечностей.

При погружном остеосинтезе осложнения связаны с неправильным выбором методики выполнения, длины, ширины и толщины фиксатора. В этих случаях кость может раскалываться, сохраняется подвижность отломков после их скрепления, что препятствует образованию костной мозоли. К осложнениям относят поломку фиксатора, его миграцию 
в мягкие ткани. Тяжелыми осложнениями погружного остеосинтеза, особенно открытого, являются поверхностное или глубокое нагноение раны, остеомиелит, некроз кожных краев раны.

Профилактика осложнений заключается в соблюдении всех требований методики выполнения остеосинтеза с учетом состояния костной ткани и индивидуальных особенностей строения кости.

Накостный остеосинтез. XX век стал решающим в развитии философии накостного остеосинтеза. В рамках развития философии AO/ASIF создан большой набор различных пластин для разных участков костей и оригинальный инструментарий. Большое значение придается прочности самого фиксатора, т.к. до консолидации отломков он принимает нагрузку на себя. В тех случаях, когда фиксатор не обладает достаточной прочностью, пластичностью и другими механическими свойствами, под влиянием нагрузки он деформируется или ломается.
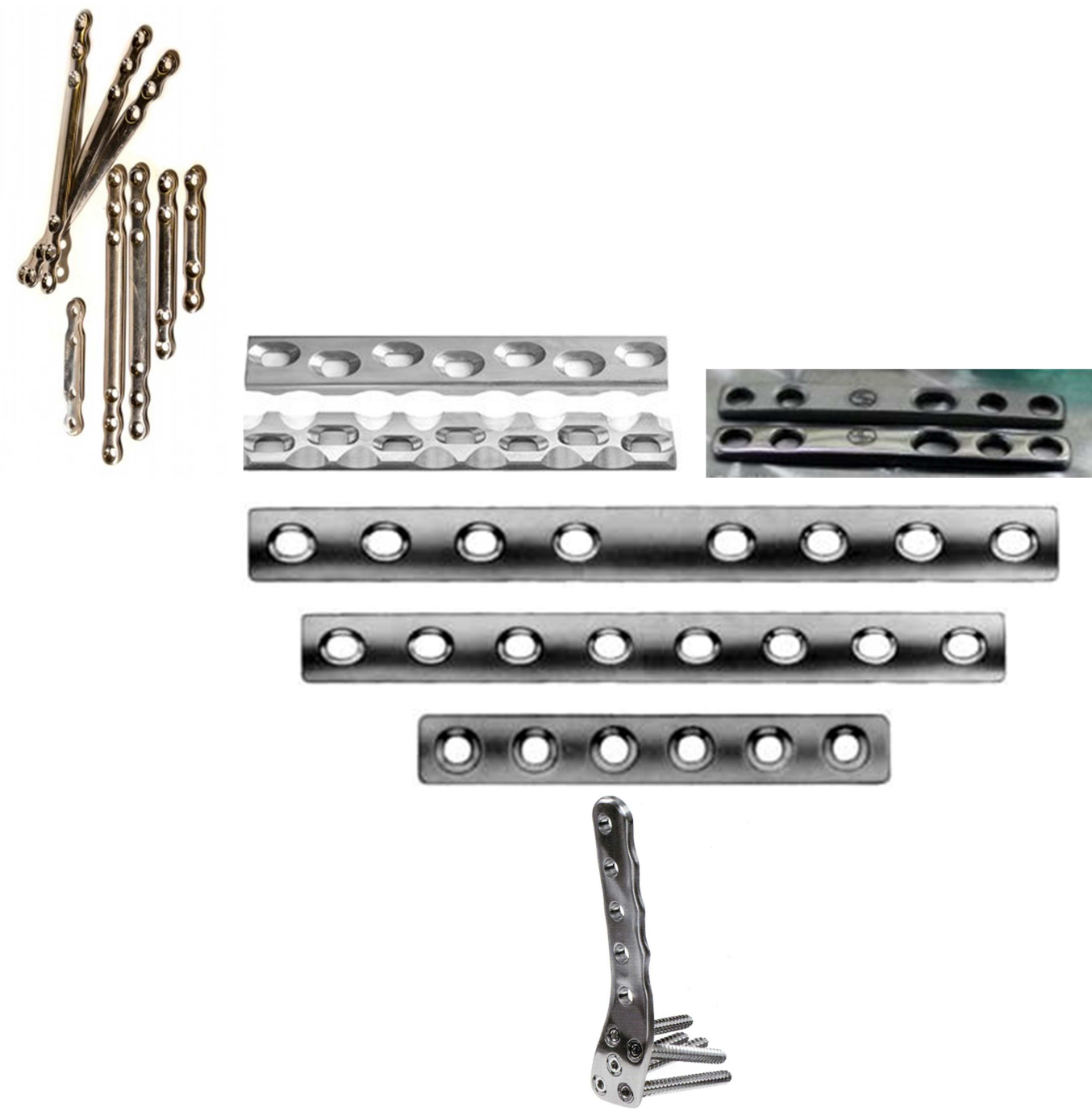

Рис. 1.10. Накостные имплантаты разного вида

Для накостного остеосинтеза используют различные виды пластин. Пластины фиксируют к кости посредством кортикальных и спонгиозных винтов. По 
биомеханическим условиям, которые создаются в зоне перелома, все пластины можно подразделить на нейтрализующие (шунтирующие) и динамически компрессирующие. Широкое распространение получили пластины с боковыми ушками, через отверстия в которых проводят винты под углом к продольной оси кости. Они получили название деторсионных, т.к. предотвращают ротационное смещение отломков.

При применении шунтирующих пластин основная часть нагрузки приходится на фиксатор. Это приводит к ряду негативных последствий: остеопорозу в ненагружаемой зоне кости, снижению эффективности остеорепарации в зоне перелома, а также к повышению риска перелома пластины и винтов. Динамически компрессирующие пластины позволяют распределить нагрузку между фиксатором и костью и избежать этих недостатков. Установка пластин в нейтрализующем (шунтирующем) режиме оправдана только при оскольчатых и многооскольчатых переломах, когда осуществление компрессии приведет к смещению отломков, а также при некоторых внутрисуставных переломах.

По способу соединения винта с пластиной выделяют: 1) пластины с круглыми отверстиями; 2) пластины с овальными отверстиями; 3) динамически компрессирующие пластины; 4) пластины с угловой стабильностью винта (рис. 1.10).

Пластины с круглыми отверстиями являются шунтирующими и в настоящее время, как правило, их применение для остеосинтеза переломов диафиза длинных костей не оправдано.

Пластины с овальными отверстиями позволяют интраоперационно добиться эффекта одномоментной межотломковой компрессии только за счет применения дополнительных устройств (контракторов), что усложняет технологию остеосинтеза и требует увеличения размеров оперативного доступа. Поэтому в настоящее время наиболее часто применяют пластины с динамической компрессией. Конфигурация отверстий пластин с динамической компрессией такова, что на заключительном этапе введения винта в кость его головка «соскальзывает» в направлении к середине пластины. Учитывая, что все отверстия расположены симметрично относительно середины фиксатора, при правильной его центрации над зоной перелома происходит сближение отломков.

При установке пластин неизбежным негативным моментом является давление имплантата на надкостницу, что приводит к нарушению в ней кровообращения, развитию атрофии кости, раннего остеопороза и замедлению процесса консолидации. Для минимизации давления фиксатора на кость были предложены пластины с ограниченным контактом, имеющие на своей прилежащей к кости поверхности сферические вырезки, значительно уменьшающие площадь соприкосновения с надкостницей. Важным этапом 
развития накостного остеосинтеза явилось создание пластин с угловой стабильностью винтов, предполагающих жесткую их фиксацию в отверстиях пластины посредством резьбы. Для большей адаптации пластины к форме кости, а также повышения прочности остеосинтеза, их изготавливают в следующих вариантах: прямые, полу-, треть- и четвертьтрубчатые (по степени изгиба плоскости пластины вдоль оси фиксатора); кроме того, пластины могут быть узкими (при однорядном расположении отверстий) и широкими (при двухрядном расположении отверстий).

Если линия или зона перелома (например, при многооскольчатых переломах) имеет большую протяженность, то для снижения травматичности оперативного вмешательства иногда прибегают к «туннельному» остеосинтезу. При этом способе остеосинтеза хирургические доступы выполняют выше и ниже места повреждения кости, а пластину проводят закрыто в толще мягких тканей. Винты в них проводят через специальный направитель по троакарам.

Для остеосинтеза отломков при около- и внутрисуставных переломах существуют специальные пластины, позволяющие эффективно прикреплять их к эпифизарным концам костей. Концевые части этих пластин изготавливают в виде опорных площадок фигурной формы с отверстиями, через которые проводят компрессирующие винты, клинки различной формы и т.д.

Мобилизацию больного начинают с первых дней после остеосинтеза. Через 6-8 нед после остеосинтеза диафиза большеберцовой кости пластиной возможна частичная нагрузка конечности. Полную нагрузку разрешают после появления клинических и рентгенологических признаков консолидации перелома, обычно через 12 нед. После накостного остеосинтеза могут наблюдаться ранние (гематома, некроз кожи, инфекция) и поздние (перелом пластины, замедленное сращение перелома, ложный сустав) осложнения. Удаление имплантатов рекомендуют производить через 18-24 мес.

Хочется еще раз отметить, что накостная пластина обычно обладает достаточной жесткостью, но ее форма только частично приспособлена к криволинейной геометрии поверхности трубчатой кости, а внутренняя, прилегающая к кости, поверхность пластины не конгруэнтна криволинейной геометрии наружной поверхности диафиза большеберцовой или бедренной кости, отдельно взятого индивидуума (пациента). Пластина учитывает лишь общие особенности геометрии поверхности трубчатой кости. Наружная поверхность диафиза большеберцовой или бедренной кости, в любом поперечном сечении, не имеет форму правильной геометрической фигуры, в частности форму круга или треугольника. Форма наружной поверхности диафиза большеберцовой или бедренной кости в поперечном сечении, изменяется вдоль продольной оси кости. 
Продольная ось диафиза большеберцовой или бедренной кости, не обязательно является прямолинейной. Наружная поверхность диафиза большеберцовой или бедренной кости, это сложная поверхность, имеющая криволинейную форму в поперечных и продольных сечениях кости. Поэтому внутренняя поверхностью пластины при установке на трубчатую кость (бедренная, большеберцовая, малоберцовая, плечевая, локтевая, лучевая) образует пятна контакта (малой площади) или давления на надкостницу, которая участвует в кровоснабжении поверхностных слоев кости, является источником костеобразования, принимает участие в образовании костной мозоли при переломах. Такой контакт разрушает надкостницу, давление на надкостницу со стороны пластины приводит к некрозу и нарушает периостальное кровоснабжение и репаративный остеогенез. При этом снижается жесткость фиксации пластины на поверхности кости, и не обеспечивается стабильность остеосинтеза. Предлагаемые рынком накостные пластины не обладают остеоиндуктивной способностью, не имеет биоактивного слоя.

Для решения всех перечисленных задач могут подойти пластины, разработанные в ходе выполнения гранта Российского научного фонда (проект № 16-15-00176). Пластина достаточно тонкая, чтобы быть установленной поднадкостнично), Имплантат выполнен из сплавленного, путем выборочной послойной плавки, металлического порошка, в форме продолговатой пластины с отверстиями, геометрическая форма внутренней поверхности конгруэнтна наружной поверхности сопрягаемой кости, построена на основе трехмерной математической модели кости, и покрыта остеоиндуктивным слоем, отверстия расположены равномерно по площади имплантата в виде сетки (Рис.1.11).

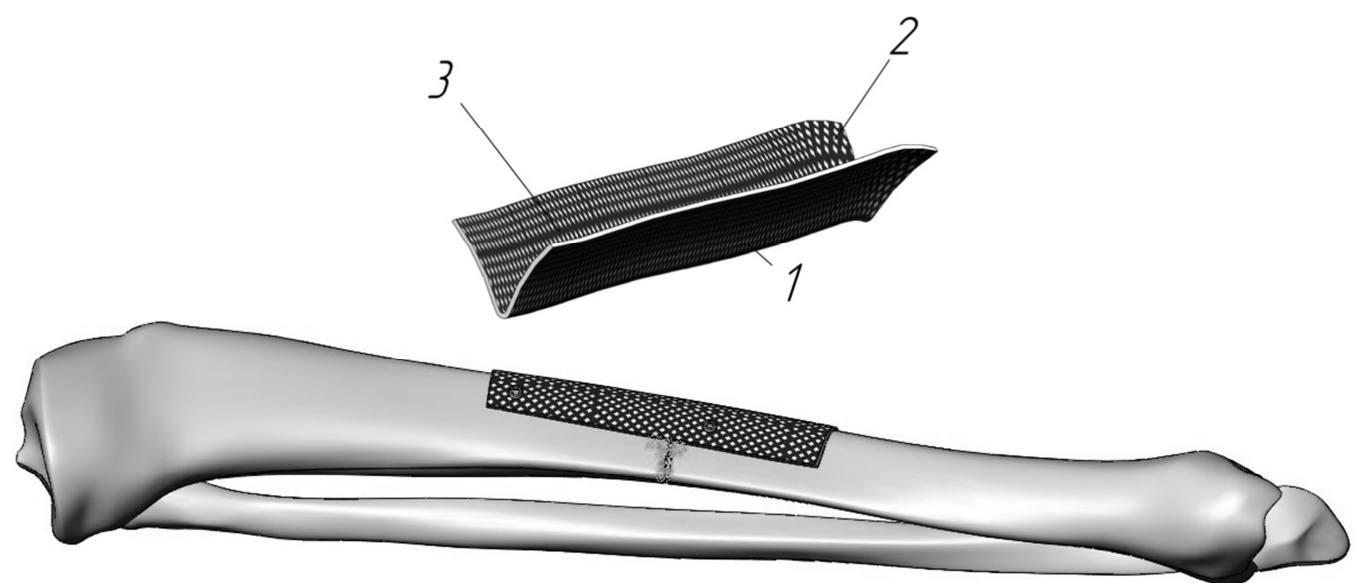

Рис.1.11. Схема накостного остеосинтеза при переломах диафиза большеберцовой кости пластиной, выполненной по аддитивной технологии (заявка на полезную модель №2016109513 от 16 марта 2016г ):1наружная поверхность имплантата, 2 - сквозные поры накостного имплантата, 3 - внутренняя поверхность имплантата.

Соответствие геометрической формы внутренней поверхности имплантата геометрической форме наружной поверхности сопрягаемой сломанной кости обеспечивает плотное прилегание имплантата, уменьшает подвижность отломков кости, увеличивает площадь контакта и имплантата с костью, обеспечивая равномерное 
распределение нагрузки на кость и снижение еe травматизации, обеспечивает улучшенный контакт остеоиндуктивного слоя с костью. Идивидуализация внутренней поверхности имплантата и наружной поверхности кости предусмотрена аддитивной технологией лазерного спекания титанового порошка в соответствии с компьютерного моделирования поверхности кости после КТ поврежденной и контрлатеральной конечности пациента. Внутренняя структура имплантата, выполненная в виде пересекающихся стропил (балок), образует в промежутках между стропилами, сквозные отверстия поперечным размер которых от 1 до 1,5 мм. Остеоиндуктивный слой может быть выполнен, например, но, не ограничиваясь, на основе гидроксиапатита, а сквозные поры в материале имплантата диаметром 300-500 мкм быстро восстанавливают кровоснабжение кости со стороны надкостницы.

Предусмотрено, что внутренняя поверхность пластины (поверхность имплантата прилегающая к кости) пористая. Предпочтительно поры сквозные, размер пор от 300 до 500 микрометров. Сквозные поры стимулируют остеоиндуктивные и остеокондуктивные процессы, способствуют восстановлению кровоснабжения кости со стороны надкостницы.

Внутрикостный остеосинтез. Для внутрикостного остеосинтеза используют полые или сплошные стержни (штифты), которые могут иметь различный профиль поперечного сечения - круглый, четырехгранный, овальный, трехгранный, полусферический, U-образный, желобоватый.

G. Kuntscher был первым, кто создал теорию внутрикостного остеосинтеза. С момента его первого сообщения на Берлинском обществе хирургов в 1940 г. прошло 75 лет. Основным итогом исследований Kuntscher в биологии и механике интрамедуллярного остеосинтеза явилось заключение о том, что все вредные для костной мозоли силы растяжения могут быть полностью устранены введением гвоздя; костные отломки, нанизанные на гвоздь, испытывают под воздействием естественной мышечной сократимости постоянную компрессию.

Отечественные ученые - Я.Дубров (1947), Ф.Богданов (1946), Н.Еланский (1953), А.Беркутов (1958) внесли свой вклад в развитие интрамедуллярного остеосинтеза, предложили свои варианты интромедуллярного гвоздя, которые имели один недостаток они были тонкие и прямые. И.И. Соколов в своей работе «Внутрикостная фиксация металлическим стержнем при переломах трубчатых костей» (1957) говорит о явном преимуществе интрамедуллярного остеосинтеза, особенно в ранние сроки после травмы, но отмечает, что «сравнительное изучение рентгенограмм с открытыми и закрытыми переломами бедра и голени, однотипными по характеру и локализации и леченными с помощью внутрикостного остеосинтеза или консервативным способом показывает, что в 
том и другом случае мозолеобразование протекает одинаково как по времени, так и по качеству» [Сергеев С.В.,2015].

В конце 80-х годов В.П. Охотский и А.Г. Сувалян предлагают в лечении переломов и ложных суставов длинных костей использовать «массивные» штифты с рассверливанием костномозгового канала [Кожахметов О.А., 2014].

Новым направлением исторического развития интрамедуллярного остеосинтеза является применение анатомически предизогнутых гвоздей с блокированием. Первичная стабильность остеосинтеза достигается не «массивностью» штифта, не трехточковой фиксацией в костном канале, не эластичностью формы, а блокированием гвоздя через технологические отверстия блокирующими винтами (рис.1.12).
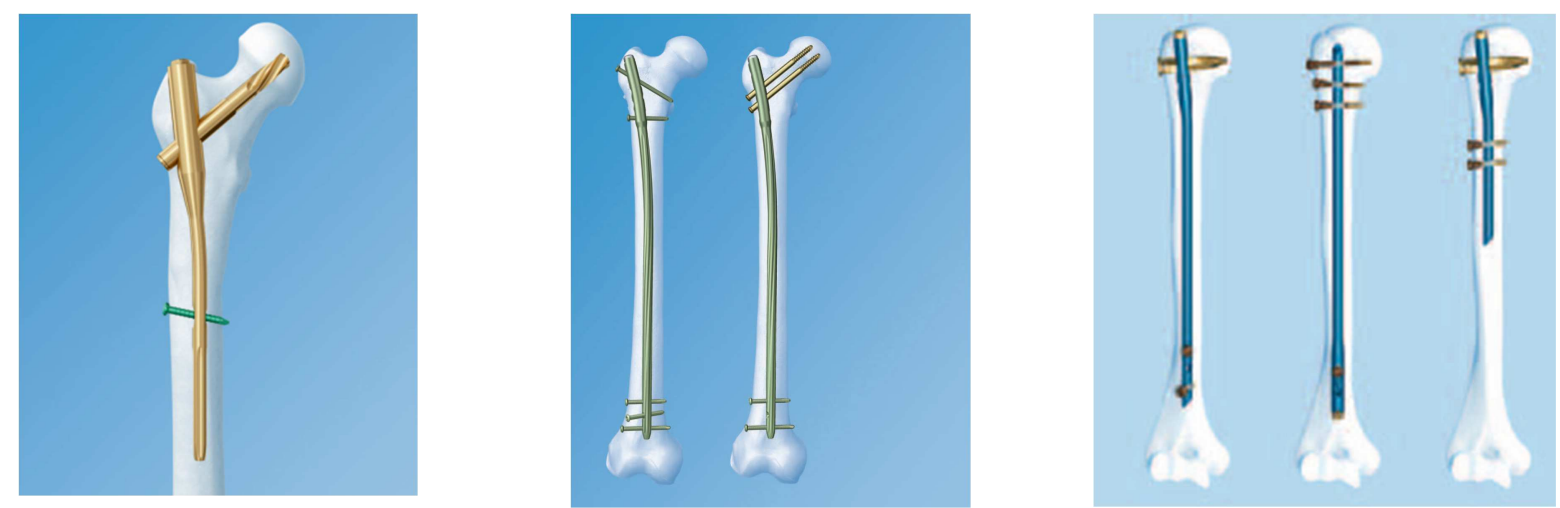

Рис. 1.12. Некоторые примеры интрамедуллярного остеосинтеза.

Эта техника препятствует потере репозиции и возникновению ротационной нестабильности. Блокирование вдали от перелома сохраняет периостальное кровоснабжение, делает свободной конечность от внешней иммобилизации. В зависимости от формы проксимального или дистального блокирования, положение сегмента (кость-гвоздь) может быть статическим или динамическим. Выбор статического или динамического блокирования зависит от характера перелома. При переломах типа А (по системе $\mathrm{AO}$ ) возможно первичное динамическое блокирование. Переломы типа В и С характеризуются первичной нестабильностью, поэтому сегмент должен находиться в статическом положении до формирования костной мозоли. В дальнейшем сегмент может быть освобожден полностью или оставлен в положении динамического блокирования для функциональной перестройки костной мозоли.

Итогом третьего периода развития интрамедуллярного остеосинтеза стало создание системы Grosse-Kempf. Рождение нового гвоздя явилось завершающим этапом разработки инструментария, дизайна гвоздя, его диаметра и эластичности (наличие разъема по длине гвоздя), обоснование рабочей длины гвоздя (длина гвоздя вне расположения отверстий для блокирующих винтов), выбора оптимального диаметра блокирующих винтов[Practise of Intramedullary Locked Nails, 2002]. Для рассверливания костномозгового канала были 
созданы гибкие римеры, рабочие головки которых прецизионно увеличивали внутренний диаметр канала, не меняя его анатомической формы. В итоге достигалась плотная посадка предизогнутого гвоздя (1500 мм). В последующем, механические тесты на скручивание, сгибание и компрессию показали, что солидный, т.е. полнотелый гвоздь, обладает большей устойчивостью ко всем видам разрушения. Однако кость не должна находиться в условиях фиксации с повышенной ригидностью имплантатом (риск развития ее атрофии), поэтому полый гвоздь является фиксатором с наиболее оптимальными механическими свойствами.

Философия интрамедуллярного остеосинтеза построена на закрытой технике остеосинтеза, применении блокируемых гвоздей с рассверливанием костномозгового канала для их плотной первичной установки, блокировании биомеханического сегмента «кость-гвоздь» в положении статического или динамического поведения в зависимости от морфологии перелома и ранней осевой нагрузки конечности. Хотя понятие закрытой техники остеосинтеза должно подвергаться значительному сомнению - рассверливание костномозгового канала, интрамедуллярный штифт по всей длине диафиза и блокирующие винты не уменьшают травматичности оперативного вмешательства.

Классификация переломов по системе АО в большинстве случаев позволяет характеризовать не только стабильность поврежденного сегмента, но и построить прогноз течения репаративных процессов. Странно, но именно простые переломы типа А1-2 иногда доставляют больше хлопот, чем переломы типа В и С. Так например, при переломе бедренной кости (A1) в нижней трети возникают трудности в центрированном введении гвоздя (синдром «раструба»). Возникающая варусная деформация требует введения транскортикальных винтов для выравнивания оси и центрального расположения гвоздя. При переломах плечевой кости, не испытывающей осевой нагрузки, заживление перелома типа А3 нередко затягивается, так как поперечная линия перелома кости полностью нарушает «гаверсово» кровоснабжение, восстановление которого происходит медленно и не всегда полноценно.

Выбор параметров имплантата и метода его введения является весьма существенной задачей. При антеградном остеосинтезе бедренной кости промах в длине гвоздя в какой-то мере простителен, но абсолютно недопустим при ретроградном введении. Выстоящий за пределами мыщелковой ямки дистальный конец гвоздя вызовет конфликт с надколенником. При остеосинтезе большеберцовой кости длина имплантата принципиальна, так как избыточно длинный гвоздь будет мешать функции разгибания голени в коленном суставе; короткий гвоздь не справится с фиксацией перелома, блокирующие винты будут находиться в зоне перелома, тем самым, препятствуя 
заживлению кости. Критическим является выбор длины имплантата для плечевой кости. Антеградный остеосинтез имеет недостаток в «путевом» повреждении вращательной «манжеты» плеча, поэтому в случае выстояния конца гвоздя impingement syndrome и контрактура плеча имеют еще более выраженное развитие. При ретроградном остеосинтезе плечевой кости следует избегать насильственного введения гвоздя из-за риска надмыщелкового перелома.

Послеоперационная реабилитация основана на трех этапах: ранний послеоперационный (до 3 недель), ближайший или промежуточный (до 3-6 месяцев) и отдаленный или заключительный (до 12 месяцев и более).

Задачами первых двух этапов реабилитации является дозированная нагрузка на конечность и полное восстановление движений в окружающих перелом суставах. При появлении костной мозоли и отсутствии болей в месте перелома разрешается увеличение осевой нагрузки и по мере укрепления костной мозоли переход на полную нагрузку. При переломах плечевой кости, осевая нагрузка которой возможна только при содействии контракции мышц, изометрическое сокращение мышц плечевого пояса играет существенное значение. Однако следует помнить, что более всего вредным для заживления переломов верхней конечности является попытка ротационных движений до появления костной мозоли. В период промежуточного этапа иногда необходимо осуществить динамизацию сегмента путем удаления статических винтов.

Таким образом, интрамедуллярный остеосинтез является сложной и высокотехнологичной операцией. Как любой вид остеосинтеза интрамедуллярный остеосинтез не лишен недостатков и не гарантирует сращение переломов во всех случаях Необходимо помнить и об отрицательном воздействии подобного остеосинтеза. Проведение внутрикостного остеосинтеза, например, при переломах диафиза бедра может значительно утяжелить общее состояние пациента. Научные исследования показали, что подобная оперативная манипуляция может оказать возддействия на мембрану циркулирующих в крови нейтрофилов, вызывая изменения поверхностных рецепторов, что известно как «пусковой механизм» или активация. Активизированные нейтрофилы резко увеличивают продукцию цитокинов и других провоспалительных медиаторов. Что ведет к повышению проницаемости мембраны эпителиальных клеток с развитием синдрома системного ответа на воспаление и поступлением жидкости в альвеолы. Ряд других общих закономерностей включает активацию процессов возбуждения и торможения при передаче нервных импульсов в ЦНС, а также приводит к перестойке маханизмов коагуляции и иммунного ответа. Все эти процессы являются частью «вторичного ответа»- феномена, при котором повреждающее воздействие первичной 
травмы («первичный ответ») усиливается за счет последующих повреждений, вызываемых вторичным ответом. Вторичный ответ могут спровоцировать затянувшаяся операция, сопровождающаяся кровопотерей, или введение в костномозговой канал бедренной кости стержней при внутрикостном остеосинтезе [W. R. Smith et al., 2013].

Чрескостный остеосинтез аппаратами внешней фиксации. Со второй половины $\mathrm{XX}$ века метод внешней фиксации стал широко применяться в практике ортопедов и травматологов благодаря совершенствованию конструкций аппаратов, созданию более прочных материалов с антикоррозийными свойствами [Девятов, А.А. 1990.]. В 1951 г. Г.А. Илизаров предложил аппарат для чрескостного остеосинтеза (ЧО), отличающийся от других расширенными возможностями по закрытой репозиции костных фрагментов и малой травматичностью. Благодаря крестообразному расположению спиц, фиксируемых в кольцевых металлических опорах, конструкция обеспечивает жесткость и одинаково прочную фиксацию костных отломков в двух взаимно перпендикулярных плоскостях, позволяя обходиться без вспомогательных средств иммобилизации и с первых дней после операции начинать активное функциональное лечение с нагрузкой на конечность [Илизаров, Г.А.,1963; 1983; Каплунов, О.А. 2002]. В настоящее время насчитывают более 300 аппаратов внешней фиксации, которые известны чаще по именам авторов, которые их разработали: О.Н. Гудушаури (1954), М.В. Волков и О.В. Оганесян (1972), В.К. Калнбернз (1974), В.М. Демьянов (1975), С.С. Ткаченко (1975) и многие другие [Немков В.А., Каравашкин Б.К., Либерман С.Б., 1977]. Обычно АВФ классифицируют по форме внешних опор и их расположению относительно конечности: монолатеральные, билатеральные, секторные, полуциркулярные, циркулярные, комбинированные (гибридные). В монолатеральных аппаратах все чрескостные элементы введены в одной плоскости и с одной стороны (аппараты Hoffmann II, Roger Anderson, Афаунова, Кривенко). Билатеральные аппараты основаны на спицах Киршнера или стержнях Штейнмана, все чрескостные элементы проведены в одной плоскости и с каждой стороны соединены оригинальными внешними опорами, образуя «раму» (аппараты Грязнухина, Фурдюка, Киреева, Сиваша, Копылова, Charnley). В секторных аппаратах введение чрескостных элементов ограничено сектором, не превышающим 180 (AO/ASIF). Полуциркулярные аппараты отличаются тем, что внешние опоры в них геометрически составляют сектор больше $180^{\circ}$ и меньше $360^{\circ}$. В устройствах этого типа могут быть использованы все виды чрескостных элементов (Fischer, Hoffmann-Vidal, Гудушаури, Волкова-Оганесяна). В циркулярных аппаратах внешние опоры полностью окружают конечность на уровне их расположения, а геометрически могут составлять круг, овал, квадрат, многоугольник и т.п. (Илизарова, Калнберза, Демьянова, Ткаченко, Kronner, 
Monticelli-Spinelli, Ettinger) [Соломин, Л.Н. 2005.]. Универсальность аппарата Илизарова и его простота способствовали популярности и широкому распространению среди травматологов-ортопедом во всем мире. Универсальность аппарата Илизарова определена незначительным по количеству набором деталей (рис.1.12), собирая которые в многочисленных сочетаниях, можно образовывать различные функциональные узлы аппарата.

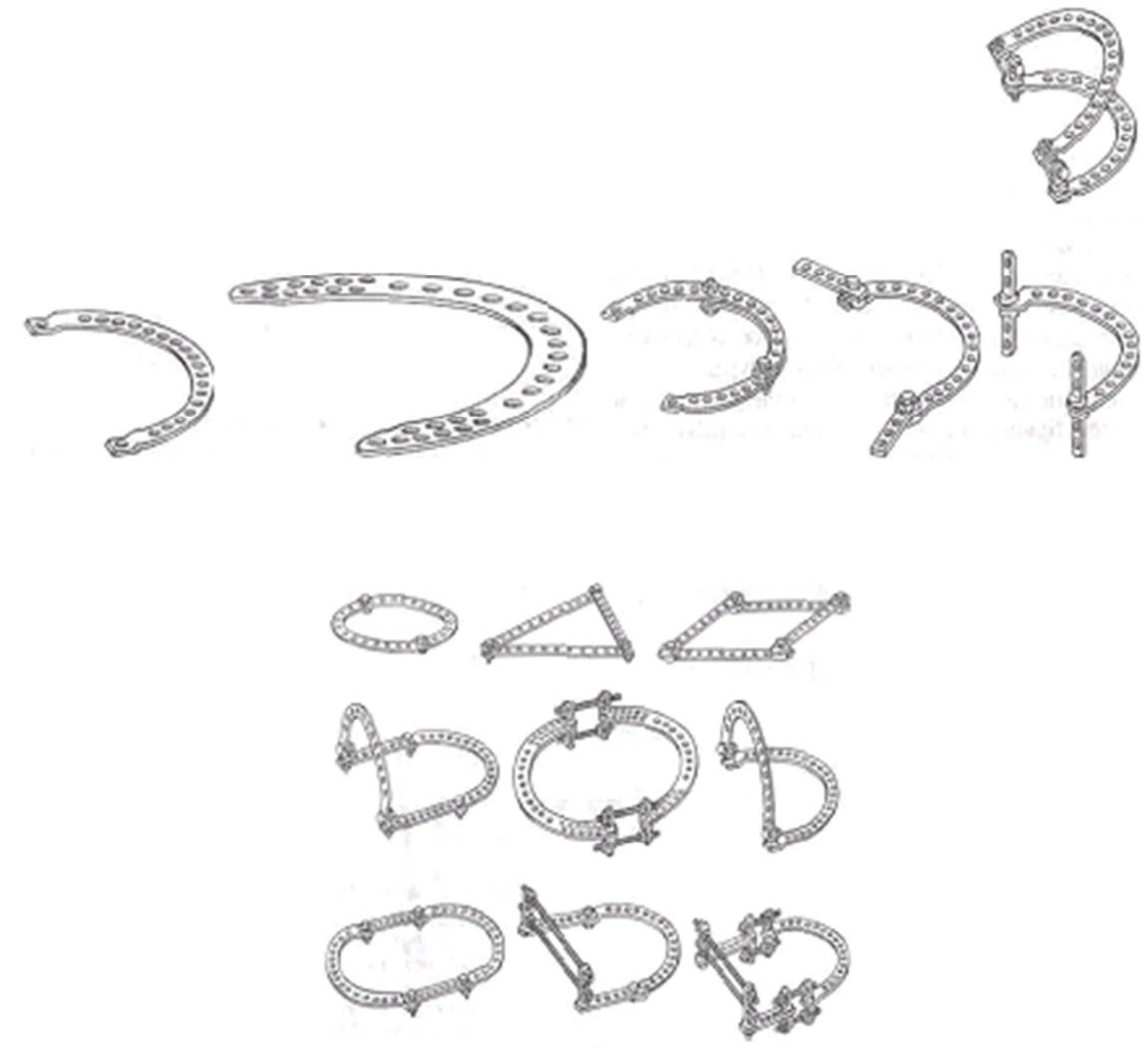

Рис. 1.12. Варианты сборки опор аппарата Илизарова замкнутой и открытой формы

Простота относиться к деталям аппарата (но ни в коем случае ни к технологии остеосинтеза), которые с момента регистрации изобретения претерпели существенные изменения, стали более просты, технологичны, универсальны. Основные детали аппарата - полукольца, дуги, планки, опорные балки - могут быть собраны в различном сочетании. Это позволяет создавать опоры аппарата самой различной конфигурации применительно к особенностям формы и размера оперируемого участка конечности, вида деформации, характера остеосинтеза и решаемой задачи.

Современный аппарат Илизарова остеосинтеза состоит из следующих основных элементов:

1) внешние опоры (имеют различную форму и размеры); 
По данным J. Vidal и соавт. (1983), «идеальным и самым стабильным является кольцевой аппарат, который обеспечивает отличную стабильность костного «очага».

2) спицы или гвозди, на которых фиксируется внешняя опора (вводятся чрескостно);

В России наибольшее распространение получили аппараты, основанные на использовании упругих элементов (спицы 1,5-2 мм в диаметре), которые фиксируются на опорах аппарата в натянутом состоянии. За рубежом чаще применяют жесткие элементы различного рода гвозди. Диаметр гвоздей, используемых в настоящее время, колеблется от 3,0 до 6,0 мм.

Сегодня и у них и у нас более популярно совместное использование (спицестержневые аппараты).

Спицы и гвозди являются своеобразными элементами связи (ЭС) внешних опор аппарата с костными фрагментами, и подобное единство можно рассматривать как узел фиксации (УФ). Главным требованием к УФ является обеспечение достаточной жесткости фиксации костных фрагментов для достижения необходимых условий регенерации костной ткани.

УФ может носить строго ограниченный характер, что обусловлено неизменной конструкцией внешних опор и строго определенным расположением элементов связи, либо обладать универсальным характером, имея неограниченные возможности изменения как формы внешней опоры, так и пространственного расположения элементов связи. Примером ограниченного УФ могут служить все односторонние аппараты типа Wagner, Hoffman I или II.

УФ универсального типа обеспечивает широкое варьирование количеством и видом элементов связи (спицы, винты, гвозди), схемами их расположения относительно друг друга и опор аппарата. Родоначальником универсального типа аппаратов является аппарат Илизарова (по этому признаку приближаются и аппараты типа Hoffman III).

Повышения жесткости УФ можно добиться увеличением диаметра и количества вводимых чрескостно спиц или гвоздей (ЭС), что неизбежно травмирует биологические ткани и снижает их репаративную активность. Это одно из противоречий, которые и определяют закономерности развития чрескостного остеосинтеза. Спицы в меньшей степени травмируют ткани конечности. Диаметр и количество гвоздей ограничены возможностью ослабления прочности кости. Диаметр гвоздя не должен превышать 20\% от диаметра кости [Vidal J. et al., 1983]. Поэтому наряду с гладкими предлагаются ЭС с резьбовой нарезкой на одном из концов или по центру, с опорными площадками. В зависимости от схемы крепления на опорах ЭС можно подразделить на двухопорные и 
консольные, а по схеме их взаимного расположения на параллельные, V-образные, Xобразные или их комбинацию.

В аппарате Илизарова, кроме того, используются спицы с упорной площадкой в кость, что значительно увеличивает жесткость аппарата при меньшем количестве спиц.

В публикациях отмечается, что с увеличением использования аппаратов наружной фиксации возросло количество осложнений, которые нередко приводят к плохим результатам. Причина осложнений - потеря жесткости фиксации из-за расшатывания металлических гвоздей в костной ткани, развитие инфекции вокруг тела фиксатора.

С этой точки зрения аппараты, содержащие спицы, имеют преимущества перед аппаратами с жесткими гвоздями [ HellingerJ., 1983]. Эти преимущества заключаются в следующем:

- меньшая травматичность, связанная с проведением и удалением спиц;

- уменьшение опасности инфицирования;

- легкая заменяемость спиц при возникновении воспаления тканей вокруг них;

- жесткость фиксации в процессе лечения не снижается благодаря возможности донатяжения спиц;

- жесткость фиксации значительно выше и достаточна для того, чтобы проводить функциональное лечение.

Развитие элементов связи видится в применении спиц с биоактивной поверхностью, которая имеет контакт с костью для борьбы с остеопорозом, возможным воспалением и активным влиянием на процесс репаративной регенерации.

Принято считать, что ЧО используется многими специалистами в качестве основного и единственного метода лечения открытых переломов длинных костей, однако выбор конкретной методики должен осуществляться с учетом уровня, глубины и протяженности повреждения мягких тканей. При этом важно соблюдать последовательность: вначале хирургическая обработка ран мягких тканей и костей, и только потом чрескостный остеосинтез.

Проводя сравнительную оценку различных способов остеосинтеза диафизарных переломов длинных трубчатых костей, Р.М. Эринле с соавторами в 1996 году пришли к выводу, что чрескостный остеосинтез показан только при лечении оскольчатых переломов, преимущественно костей голени, а остеосинтез пластиной $\mathrm{AO}$ может с успехом применяться при поперечных и косых переломах любых уровней и локализаций, а интрамедуллярный - при лечении аналогичных переломов в средней трети бедренной, лучевой и локтевой костей. Фиксация винтами возможна при винтообразных переломах большеберцовой кости. При правильном выборе способа остеосинтеза и технике его 
выполнения авторы получили положительные исходы в 95 \% случаев [Р.М. Эринле, А.В. Рак, С.А. Линник,Г.П. Салдун,1996]. В то же время Л.Викторова (1995г), сравнивая отдаленные результаты лечения закрытых и открытых переломов длинных трубчатых костей, пришла к выводу, что лучшие результаты лечения больных с переломами костей конечностей получаются при использовании аппарата Илизарова, где осложнения составляют 2,8\%. В то же время послеоперационные осложнения после применения внутреннего остеосинтеза (стержни, гвозди, пластины, балки) возникают в $17,1 \%$ случаев [Викторова, Н.Л.,1995].

Другой общепризнанной сферой применения ЧО считаются огнестрельные переломы, сопровождающиеся обширным повреждением мягких тканей. По сравнению с гипсовыми повязками, открытой репозицией с последующей фиксацией накостными пластинами и интрамедуллярным остеосинтезом, остеосинтез аппаратом Илизарова значительно снижает процент осложнений [ Авденко, А.Г. 2010; Ахмедов, Б.А. 2010].

Критическая оценка остеосинтеза переломов аппаратами внешней фиксации заставила отказаться от метода ЧО в тех областях, где технологии внутреннего остеосинтеза не менее эффективны, но при этом сокращаются сроки стационарного лечения и в меньшей степени ухудшается качество жизни больного. Следовательно, дальнейшее рациональное развитие методов остеосинтеза видится в сохранении положительных свойств внутренней фиксации (сокращение сроков стационарного лечения, лучшее качество жизни пациента в период лечения) и несомненного преимущества АВФ (стабильная фиксация костных фрагментов даже при выраженном остеопорозе, малая травматичность оперативного вмешательства и сохранение целостности остеогенных тканей). В этом отношении особого внимания заслуживает достаточно простая технология остеосинтеза монолатеральным фиксатором с одновременным интрамедуллярным армированием поврежденного сегмента конечности тонкими спицами с биоактивным покрытием гидроксиапатитом (глава 4) [Попков А.В. с соавт., 2015].

В последние годы сформировалось новое представление об оказании помощи при переломах конечностей: большинство переломов можно лечить сразу или поэтапно малоинвазивными методами фиксации, когда малая кровопотеря, снижение риска инфицирования и сокращение сроков сращения оказывают благоприятное влияние на исходы для пострадавших, снижают уровень возможной инвалидизации. Сочетание малотравматичной чрескожной репозиции и фиксации в комбинации со специальными имплантатами произвели настоящий переворот в лечении переломов [Sommer C., Bereiter H., 2005; Perren S.M., 2002]. Особое место занимает комбинированный остеосинтез с 
использованием интрамедуллярных биоактивных имплантатов. Впервые индуцирование остеогенеза интрамедуллярными спицами при переломах голени использовали в РНЦ «ВТО» им. академика Г.А.Илизарова (г.Курган, Россия) в 2001 году доктором Попковым Д.А. Впервые появилась возможность активного влияния на репаративный остеогенез биологически активной поверхностью незначительного по массе имплантата.

Остеосинтез, оперативная фиксация костных отломков является приоритетным направлением лечения переломов конечностей, но при тяжелом или неустойчивом состоянии пациента (шок, коагулопатия, гипотермия, нарастающая симптоматика черепно-мозговой травмы) очередность оказания помощи осуществляется по протоколу “damage control” (DCO) - ранняя временная стабилизация перелома простыми наружными фиксаторами (монолатеральные аппараты внешней фиксации), с последующей окончательной фиксацией после стабилизации общего состояния пострадавшего и уменьшения клинических проявлений воспаления (через 5-10 дней после травмы)[ Ключевский, В.В., 2010; Pavolini, B., 2000].

\section{3. Значение костного мозга в репаративном остеогенезе}

Вопросы о происхождении клеток, участвующих в остеогенезе, постоянно находятся в центре нашего внимания ввиду того, что современная наука предоставляет новые сведения о патогенетических механизмах регенерации костной и других тканей организма при восстановлении после травмы или при удлинении конечности.

В настоящее время доказано, что костный мозг - источник остеогенных клеток. Исследования, проведенные с использованием метода монослойного клонирования костного мозга in vitro, позволили установить их природу. В таких условиях формируются колонии типичных фибробластов, отражающих уровень содержания КОКф. В смешанных культурах костного мозга мышей линий CBA и CBAT-6 с помощью типирования метафазных пластинок была показана клональная природа этих колоний. Многие характеристики фибробластов животных и человека хорошо изучены. Эти клетки синтезируют фибронектин, коллаген типов $1,2,3,5$, дают положительную реакцию на щелочную фосфатазу - маркер остеогенной дифференцировки и, самое главное, - при обратной трансплантации в организм образуют костную ткань [Фриденштейн А.Я., 1991]. Например, клетки штаммов, выращенных от КОКф, способны в культуре формировать достаточное количество костной ткани, что указывает на высокую пролиферативную активность, хотя в костном мозге они находятся вне митотического цикла [Герасимов Ю.В. и др., 1986]. Костная ткань также формируется при длительном культивировании стромальных механоцитов в диффузионных камерах и в органных культурах костного 
мозга, однако для этого требуется присутствие в среде глицерофосфата натрия и аскорбиновой кислоты [Лурия Е.А. и др., 1989].

Содержание КОК также зависит от сезонности. Уровень клеток-предшественников стромальных механоцитов изменяется также и при различных заболеваниях крови - лейкозах [Зарицкий А.Ю. и др., 1982], при травмах и болезнях скелета [Зарицкий А.Ю. и др., 1983; Minguell J.J., Martines J., 1983].

Интересно, что обнаруженная в эксперименте способность костного мозга и культур фибробластов к остеогенезу применяется в качестве основы некоторых способов стимуляции костеобразования, заключающихся, в частности, в эксплантации культуральных штаммов фибробластов или костного мозга в область костных дефектов [Осипян И.А., Айвазян В.П., 1985]. При этом ускоряется течение репаративного процесса. Положительный эффект при лечении дефектов костей оказывает их замещение наполнителем, импрегнированным аутологичным костным мозгом. В этом случае сокращаются сроки лечения за счет ускорения образования костного регенерата. В ряде случаев для предупреждения ортопедических осложнений применяют строму костного мозга от доноров, предварительно иммунизированных стафилококковым анатоксином. В то же время трансплантация стромальных механоцитов с углеродистыми материалами не ускоряет остеогенез.

Таким образом, клоногенные предшественники стромальных механоцитов (фибробластов) могут выполнять функцию стволовых клеток костной ткани. Они способны к длительному самоподдержанию, образуют клеточное потомство с различными типами дифференцировки, включая костные, хрящевые и ретикулярные клетки. Потомками КОК $ф$ являются остеобласты, значение которых в функционировании костной ткани детально описано.

Оставаясь сторонниками концепции взаимосвязи остеогенеза и гемопоэза, попытаемся также проследить возможные связи этих клеток с кроветворением, не вдаваясь в детальное описание их функций.

Существование взаимосвязи кроветворной и костной тканей доказывается уже самим фактом их тесной анатомо-функциональной общности. В частности, подтверждением этого является пространственная модель организации ГИМ, в которой данные ткани имеют общую систему микроциркуляции, иннервации и общие клеточные элементы. Характерно, что гранулоцитарные колонии локализуются интенсивнее вблизи эндоста, эритроидные связаны с центральной зоной медуллярной полости, гранулоцитарные и недифференцированные колонии часто соприкасаются с 
остеокластами. Таким образом, пролиферация, дифференцировка и созревание кроветворных клеток связаны с функционированием костной ткани. В этом плане интересно, что повреждение костного мозга приводит к активации остеобластов не только в зоне повреждения, но и в интактных костях. В частности, при лимфобластном лейкозе на фоне лечения 6-меркаптопурином и преднизолоном в период, предшествовавший восстановлению кроветворения, наблюдались аплазия костного мозга и интенсивное новообразование костной ткани с участием остеобластов. В более поздние сроки исследования трепанобиоптатов при тяжелой апластической анемии в костном мозге отмечалось значительное увеличение площади губчатой кости и количества остеоидных клеток на единицу площади, указывающее на ускоренный синтез костного матрикса и усиление пролиферативной активности остеогенных клеток-предшественников. Эти наблюдения свидетельствуют о том, что кроветворная и остеогенная клеточные линии связаны между собой в физиологических условиях и при воздействии на организм экстремальных факторов. Обнаружено, что при малой плотности посева клеток костного мозга на 7-10-е сутки в культуре появляются фибробластоподобные клетки, к 15-17-м суткам определяется структурированная картина стромально-клеточного роста и начинают выявляться гемопоэтические предшественники. Это позволило предположить существование единой стволовой клетки для гемопоэтических и стромальных клеток, и что ее раннее развитие идет по стромальной линии, а затем индуцирует образование кроветворных клеток [Huang S., Terstappen L.W., 1992]. Между кроветворными и стромальными клетками имеются регуляторные взаимоотношения, которые проявляются в различных формах. Один из важных результатов взаимодействия остеогенеза и гемопоэза - продукция остеокластов.

Таким образом, при аплазии костного мозга усилен остеогенез, причины которого могут быть различными. Соотношение между объемом кости и массой кроветворной ткани в ней не укладывается в простую количественную зависимость, что показано в условиях эктопического остеогенеза и остеопороза [Алмазов В.А. и др., 1990].

В целом есть основания считать, что взаимосвязи кроветворения и костеобразования сложны и реализуются при участии родоначальных клеток с включением в процесс циклических нуклетоидов, гормонов и других регуляторов [Свешников А.А. и др., 1996]. Остеогенные потенции костного мозга контролируются тимусом. В частности, при тимэктомии снижается величина костного органа после гетеротопной трансплантации костного мозга [Тодрия Т.В., 1992], повышается минерализация костного матрикса, задерживается рост скелета. 
Интересные данные об остеогенных потенциях костного мозга диафиза кости получены на экспериментальной модели дефекта кортикальной пластинки при сохранении целостности костного мозга и медуллярных сосудов. Показано, что при удалении костного мозга краевые дефекты диафиза заполняются костной тканью в участках, прилежащих к вскрытой костномозговой полости. Сохранение костного мозга и сосудов в зоне кортикального дефекта обеспечивает восстановление не только целостности кости, но и ее формы. Костеобразование при этом характеризуется высокой степенью активности и завершается в минимальные сроки. Наиболее ярко остеогенные потенции костного мозга проявились в серии опытов при изоляции его от параоссальных тканей пленкой, не препятствующей объемному увеличению регенерата. При этом регенерат не только заполнял весь дефект, но и выходил за его границы. Эти эксперименты подтвердили важное значение костного мозга в процессах восстановления трубчатой кости. Костный мозг проявляет высокую остеогенную активность, он способен продуцировать полноценную костную ткань в короткие сроки, а при определенных условиях (сохранности костного мозга в месте естественной локализации, полноценном кровоснабжении, механическом покое и изоляции от параоссальных тканей) костная ткань образуется со значительным избытком.

Еще в 1985 г. А.А. Шрейнер опубликовал отчет о научно-исследовательской работе «Изучение роли костного мозга в регенерации кости», которую он завершил под руководством Г.А. Илизарова (номер гос. регистрации 01820075214). В эксперименте с 36 собаками изучались остеогенные потенции костного мозга при создании различных дефектов диафиза большеберцовой кости. Полученные результаты выявили удивительные возможности костного мозга по продуцированию полноценной костной ткани в короткие сроки в большом объеме. Уже с 3-го дня после операции в толще жирового костного мозга в зоне циркулярного дефекта большеберцовой кости и в прилегающих участках костномозгового канала отломков появляются очаги пролиферации клеточных элементов, через 5-7 дней регенерат представлен скелетогенной тканью с сетями костно-остеоидных балочек, а через 2-3 недели практически вся зона дефекта заполняется новообразованной губчатой костной тканью. К 1,5-2-м месяцам опыта формируется разреженная кортикальная пластинка, покрытая типичной надкостницей, и единый с прилегающими фрагментами костномозговой канал (рис. 1.13). 


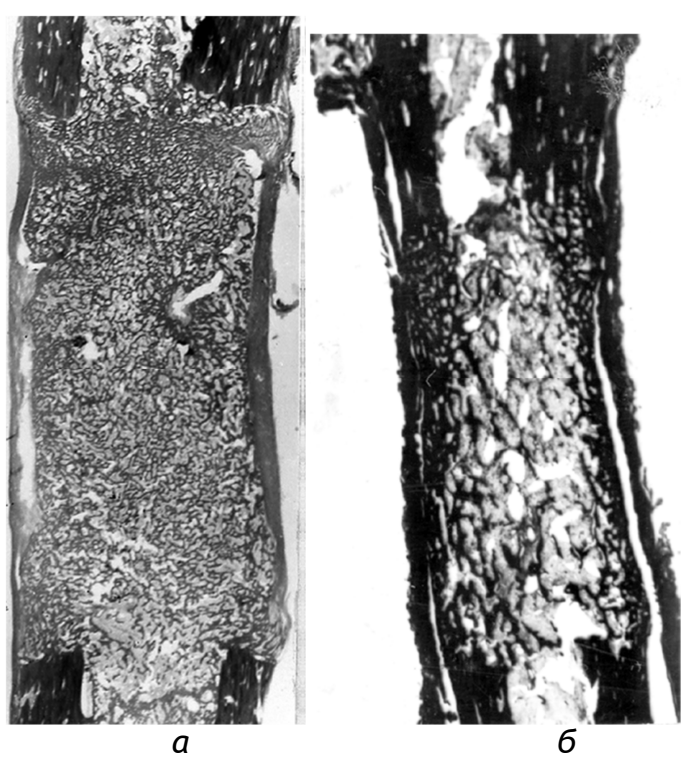

Рис. 1.13. Гистотопограммы, отражающие процесс костеобразования в костном мозге собаки при циркулярном дефекте большеберцовой кости длиной 24 мм: а - через 21 день; б - через 2 месяца.

Рентгенологически через 14-21 день стабильной фиксации плотная гомогенная тень остеогенной ткани выполняет все пространство дефекта между костными фрагментами, не выходя за границы большеберцовой кости (рис. 1.14a). В процессе дальнейшего наблюдения отмечается постепенное уплотнение вновь образованной на месте костного мозга кости (рис. 1.146, в).
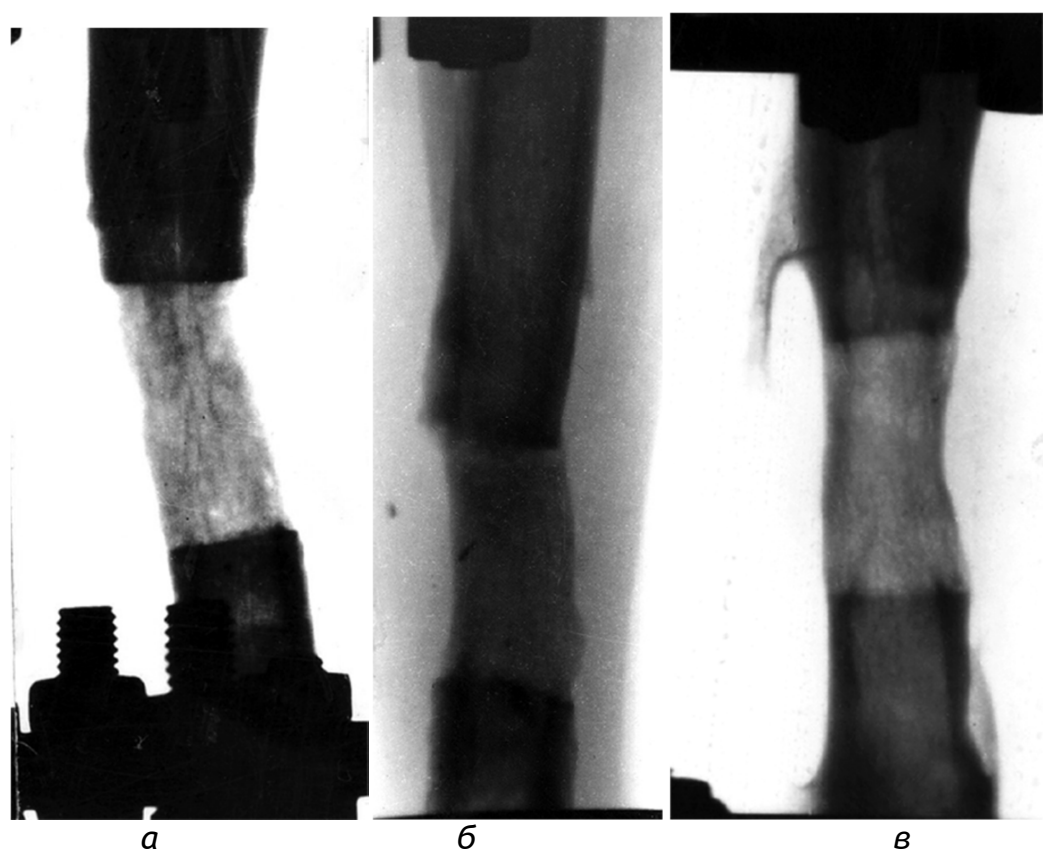

Puc. 1.14. Рентгенограммы большеберцовой кости собаки: $a$ - через 21 день; $\sigma$ - через 35 дней; $в$ - через 2 месяца. 
Подобная яркая картина костеобразовательной функции возможна только при плотной изоляции костного мозга от окружающих мягких тканей. Костномозговая артериальная сеть реагирует ранней и стойкой гиперваскуляризацией и в достаточной степени обеспечивает интенсивное костеобразование (рис. 1.15).

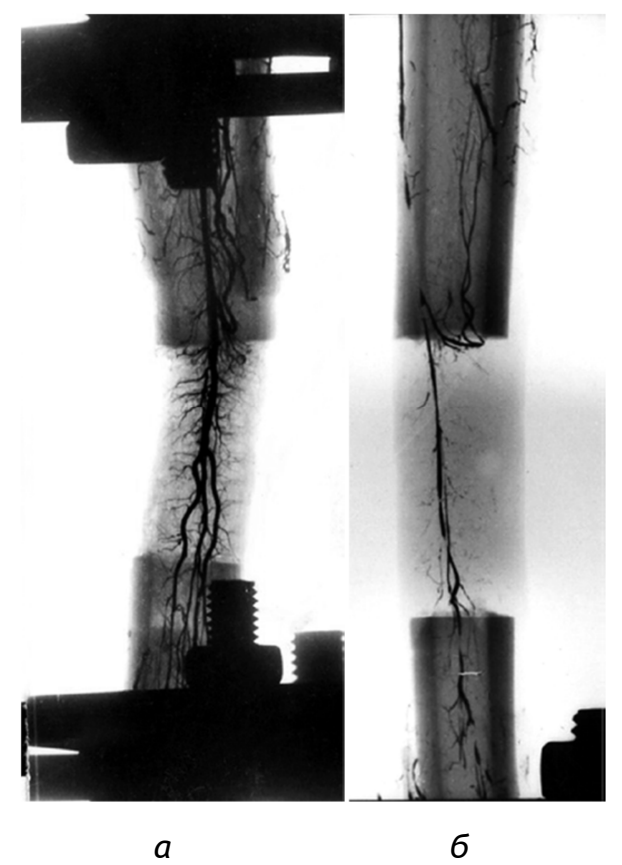

Рис. 1.15. Ангиограммы костномозговых артерий при плотной изоляции костного мозга от окружающих мягких тканей: а — через 7 дней; б - через 21 день.

Таким образом, логично констатировать, что костный мозг обладает остеогенными потенциями, являясь источником основных клеточных элементов, участвующих в костеобразовании, - остеобластов и остеокластов, фибробластов и моноцитовмакрофагов. Костный мозг диафиза способен без участия надкостницы, эндоста и параоссальных тканей заполнять в короткие сроки значительные циркулярные дефекты кортикальной стенки. Для подобного эффекта необходимы определенные условия: покой в зоне регенерации, полноценное кровоснабжение костного мозга и изоляция от параоссальных тканей. Выявленные возможности костного мозга в дальнейшем нашли практическое применение в травматологии и ортопедии при реальной стимуляции репаративного остеогенеза с целью сокращения сроков консолидации перелома, а также воздействия на гистогенез костной ткани в постнатальном периоде [Попков А.В., Попков Д.А.,2012].

\section{4. Динамика восстановительных процессов при повреждениях конечности}

Многие классические установки, действующие при лечении изолированных переломов, неприемлемы или требуют корректировки применительно к лечению 
переломов у больных с сочетанной и множественной травмой в зависимости от общего состояния пострадавших, тяжести повреждения головного мозга и внутренних органов. Доказано, что лечение больных при политравме значительно труднее и заканчивается с большим числом осложнений и неблагоприятных исходов [Агаджанян, В.В. 2003; Ахмедов, Б.А. 2010; Мартель, И.И. 1996; Швед, С.И. с соавт. 2006. В.P. Scannell [et al., 2010; T. Suzuki [et al., 2010]. Повреждения длинных костей конечностей, главным образом нижних, наблюдаются у $2 / 3$ пациентов с множественной и сочетанной травмой. Большая костно-мышечная масса нижних конечностей приводит к эффекту системного воздействия травмирующего агента. Кровотечение и увеличение объема интерстициальной жидкости сопровождается гиповолемией и снижением АД, При наличии размозженных ран высвобождается в значительных количествах клеточный детрит, клетки костного мозга, миоглобин и другие продукты распада мышечной ткани. Эти вещества могут привести к развитию жировой эмболии, респираторного дистресссиндрома взрослых (РДСВ), острой почечной недостаточности или полиорганной недостаточности. Поэтому знание и контроль обменных процессов особенно важны не только в дооперационный период, но и в процессе восстановительного периода.

Раннее и правильно выполненное оперативное вмешательство малоинвазивными методами отражается, в конечном итоге, на общем состоянии пациента и предотвращает тяжелые инфекционные осложнения (клостидиальный миозит, некротизирующий фасцит, остеомиелит). Ранняя стабилизация способствует менее выраженным проявлениям ответной реакции организма на перелом, в том числе, синдрома септического состояния, уменьшаются болевые ощущения, сокращаются сроки начала активизации больного, что предупреждает развитие дыхательной недостаточности и желудочно-кишечной дисфункции.

\subsection{1. Адаптационная перестройка обменных процессов организма в ответ на} действие стрессовых факторов на организм. Любое действие экстремальных факторов вызывает изменение внутренней среды организма, связанное с адаптационной перестройкой обменных процессов, позволяющих ему существовать в новых, изменившихся условиях [Быков А.Т., Питерская Я.А., Труханов А.И., 2007]. При всем разнообразии различных по силе и качеству раздражителей в организме, в ответ на их действие, происходят общие неспецифические изменения всех звеньев метаболизма, которые сопровождаются колебанием субстратов их обмена в плазме крови [Власов В.В., 1994; Гаркави Л.Х. и др., 1998; Соков С.Л., Соков Л.П., 1999; Труханов А.И., 2006]

В литературе имеется значительное количество работ, посвященных изменению биохимических показателей крови после различного рода внешних воздействий, в том 
числе скелетных и черепно-мозговых травм. Показано, что вне зависимости от типа раздражителя в белковом обмене происходят однотипные реакции, сопровождающиеся изменением концентрации различных белковых компонентов плазмы [Беляевский, А.Д., Русская И.В., Беляевский С.А., 1999; Али П., 2000]. Большинство авторов в постстрессорный период отмечают явление развивающейся гипопротеинемии. Снижение уровня общего белка и альбумина в сыворотке крови людей наблюдается после механической травмы [Лифшиц Р.И., Волчегорский И.А., Рябинин В.Е. и др., 1988; Бецишор В. К., 1988] гипоксии [Горанчук В.В., Шустов Е.Б., Андреева Л.И. и др., 1999], гипо- и гипертермии [Горанчук В.В., Шустов Е.Б., 1997; Горанчук В.В., Шустов Е.Б., Андреева Л.И. и др., 1999]. Ряд авторов наряду с гипопротеинемией отмечают рост концентрации мочевины в крови: после механической травмы [(Дерябин И.И., Насонкин О.С., 1987; Хамидов Б.Х., Джалилов П.С., Каратаев И.С., Золотова Н.Н., 2002; Земченков, А.Ю., Томилина Н.А., 2004], после воздействия экстремальной гипертермии [Горанчук В.В., Шустов Е.Б., 1997; Малахова М.Я., 2000].

Изменения, происходящие в углеводном и липидном обмене, после внешнего воздействия связаны с активацией под действием гормонов надпочечников процессов липолиза и гликогенолиза [Зайчик А.Ш., Чурилов Л.П., 1999]. Если для углеводного обмена однозначно показано, что любое стрессирующее воздействие приводит к развитию гипергликемии [Горанчук В.В., Шустов Е.Б., 1997; Тимошенко О.П., 1997; Горанчук В.В., Шустов Е.Б, Андреева Л.И. и др., 1999; Немченко Н. С., Гончаров А. В., Борисов М. Б., 2001], то изменения уровня липидов в сыворотке, согласно литературным данным, носят противоречивый характер. Так, у людей травма и последующее лечение различными оперативными методами, по одним данным, могут приводить к снижению общего холестерина [Дерябин И.И., Насонкин О.С., 1987; Немченко Н.С., Ерюхин И.А., Шанин В.Ю., 1991; Андрианова М. Ю., Палюлина М. В., Кукаева Е. А., Мильчаков В. И., 2001; Tochigi M., Umekage T., Otani T. et al., 2002], а по другим данным - не влиять на изменение его концентрации в крови [(Мороз В.В., Молчанова Л.В., Щербакова Л.Н. и др., 2001]. Для людей в одних случаях обнаруживается снижение концентрации общих липидов после переломов и в ходе лечения [Лавринович Т.С. и др., 1979; Андрианова М.Ю., Палюлина М.В., . Кукаева Е.А, Мильчаков В.И., 2001; Мороз В.В., Л. Молчанова В., Щербакова Л.Н. и др., 2001; Горев С.Г., Еликова Е.П., Тукмачев О.А. и др., 2002], в других, после ортопедических операций, их уровень в сыворотке не изменяется [Chubzicki R.,1958].

Снижение концентрации триглицеридов в сыворотке крови людей после травмы и ортопедических операций отмечено к 1-3 суткам после операции при лечении травматологических больных различными методами, в том числе и методом чрескостного остеосинтеза [Горев С.Г., Еликова Е.П., Тукмачев О.А. и др., 2002].

Почти всеми авторами отмечаются сдвиги в энергетическом обмене после внешних воздействий, которые связаны с активацией анаэробного пути метаболизма и сопровождаются накоплением в сыворотке крови молочной и пировиноградных кислот [Кулагин В.К., 1978; Лукьянова Л.Д., Михайлова Н.Н., Фоменко Д.В. и др., 2001; Gulati SC, Sood SC, Bali IM, Kak VK., 1980; Chang WH., 1993; Shiogai T, Nara I, Saruta K, Hara M, Saito I., 1999; Nicholls TP, Shoemaker WC, Wo CC, Gruen JP, Amar A, Dang AB., 2006].

Работами последних лет показано, что стрессы различной этиологии усиливают также генерацию свободных радикалов и активацию ПОЛ, что приводит к росту в сыворотке крови концентрации продуктов перекисного окисления - малонового диальдегида (МДА) и диеновых конъюгатов (ДК). Увеличение содержания продуктов ПОЛ в крови обнаруживается после механической травмы (Шапошников Ю.Г., Назаренко Г.И., Розинов В.М. и др., 1990; Али, П., 2000; Голиков П.П., Смирнов С.В., Матвеев С.Б. и др., 2000; Bullock R., Landolt H., Axwell W.L., Fujisawa H., 1994; Cristofori L., Tavazzi B., 
Gambin R. et al., 2001), при гипоксии [Горанчук В.В., Шустов Е.Б., Андреева Л.И. и др., 1999), гипотермии (Львова С.П., Горбунова Т.Ф., Абаева Е.М., 1993; Горанчук В.В., Шустов Е.Б., Андреева Л.И. и др., 1999], после облучения [Чернега Л.И., 1997; Зубкова С.М., 1997], выполнения физической нагрузки [Логоша С.А., Морозов В.И., Рогозкин B.A., 1996; Jenkins R.R., 1993; Balogh N., Gaal T., Ribiczeyne P.S. et al., 2001], после острой кровопотери [Матвеев С.Б, Марченко В.В., Попова Т.С. и др., 1999; Костюшко А.В., Кузьмин И.И., Маркелова Е.В., Чагина Е.А., 2005], при гиподинамии [Гераськина М.А., 1996; Зубкова С.М., 1997]. Если активация ПОЛ после внешнего воздействия отмечается почти всеми исследователями и не зависит от вида действующего раздражителя, то литературные данные по изменению АОС противоречивы. Например, при гипотермии наряду с активацией ПОЛ отмечено снижение в эритроцитах активности фермента антиоксидантной системы - супероксиддисмутазы [Зубкова С.М., 1997; Горанчук В.В., Шустов Е.Б., Андреева Л.И. и др., 1999]. При облучении наоборот, в эритроцитах происходит рост ее активности [Чернега Л.И., 1997], в других случаях, например при кровопотере, гипертермии изменений ферментного звена АОС не наблюдалось [Горанчук В.В., Шустов Е.Б., 1997; Матвеев С.Б., Марченко В.В., Попова Т.С. и др., 1999; Bullock R., Landolt H., Axwell W.L., Fujisawa H., 1994].

Считают, что в развитии воспаления существенное значение принадлежит неконтролируемым реакциям свободно-радикального окисления, что характеризуется как «окислительный стресс». В его формирование большой вклад вносят нарушения ферментативного звена антиоксидантной системы [Костюшко А.В., Кузьмин И.И., Маркелова Е.В., Чагина Е.А., 2005].

Многие авторы, изучавшие динамику показателей крови после внешних воздействий, отмечают, что концентрация тех или иных продуктов обмена зависит от силы такого воздействия. Так, в ряде работ показана взаимосвязь уровня гипопротеинемии, гипергликемии, гиперазотемии, гиперлактатемии с тяжестью механической травмы [Дерябин И.И., Насонкин О.С., 1987; Немченко Н.С., Ерюхин И.А., Шанин В.Ю., 1991; Масютин В.А., Вашетко Р.В., Широков Д.М., 1994; Cuthbertson D.P., 1998; Gebhard F., Riepl C., Liener U.C. et al., 2000; Coats T. J., Smith J.E., Lockey D. et al., 2002; Jeng J.C., Jablonski K., Bridgeman A. et al., 2002; Su H, Aharonoff GB, Zuckerman JD, Egol KA, Koval KJ., 2004]. Установлено также, что с увеличением силы внешнего воздействия возрастает и активность реакций ПОЛ [Еликов А.В., Цапюк П.И., 2001; Pintaudi A.M., Tesoriere L., Arpa N. D' et al., 2000; Henzler D, Cooper DJ, Mason K., 2001]. Опираясь на эти факты можно предположить, что изменения биохимических параметров сыворотки крови в посттравматический период позволяют оценивать интенсивность внешнего воздействия.

При определении степени травматического повреждения особое внимание ряд авторов уделяет исследованию уровня ферментов сыворотки [Шапошников Ю.Г., Назаренко Г.И., Розинов B.М. и др., 1990; Ronzoni G., Carli F., 1992; Basile-Filho A., Marques M. S. V., Auxiliadora M. M. et al., 2001; Caglayan F., Caglayan O., Gunel E. et al., 2002]. B.A. Масютин с соавт. считает, что развивающаяся при травме гиперферментемия является основным критерием для определения степени повреждения клеток определенного органа [(Масютин В.А., Вашетко Р.В., Широков Д.М., 1994]. Это связано со специфической органной локализацией отдельных ферментов. Известно, что АлАТ, АсАТ, ЛДГ являются маркерами поражения сердца, печени, скелетных мышц; КК - сердечной и скелетной мышц и т.д. (Chubzicki R., 1958; Chavez Moreno J., Bickhardt K., 1997; Roy, K., De A. U., Sengupta C., 2000).

При определении тяжести травматического повреждения особое внимание обычно уделяют исследованию кислотно-щелочного состояния организма (КЩС) [Rehm M, Conzen PF, Peter K, Finsterer U., 2004; Clausen T, Khaldi A, Zauner A. et. al., 2005; FitzSullivan E, Salim A, Demetriades D, Asensio J, Martin MJ., 2005]. 
1.4.2. Развитие синдрома эндогенной интоксикации. Интоксикация - типовой патологический процесс, возникающиий в результате действия на организм токсических веществ эндо - или экзогенного происхождения и проявляющийся в течение основного заболевания [Камкин А.Г., Каменский А.А., 2004]. Эндогенное происхождение токсических веществ подразумевает их образование в организме, хотя эти вещества не предусмотрень физиологическими прочессами. С биохимических позиций эндогенную интоксикаџию (ЭИ) следует рассматривать как изменение регулящии обмена веществ или метаболический ответ организма на любой агрессивный фактор [Малахова М.Я., 2000].

Синдром ЭИ, в большей или меньшей степени, сопутствует любому соматическому, инфекционному, хирургическому и другому заболеванию и в настоящее время трактуется как комплексная ответная реакция организма на массивное поступление в кровоток эндогенно образующихся токсических веществ, сопровождающееся интенсивным воздействием на его системы защиты чужеродных антигенов. На определенной стадии эндотоксикоз приобретает характер болезненного явления, приводящего к значительному нарушению деятельности органов и систем организма, при этом для него характерна избыточность ответа, неадекватная инициировавшему его стимулу [Повзун С. А., 1991]. К состояниям, сопровождающимся эндотоксикозом, относятся:

- синдром длительного раздавливания или рециркуляции после длительной ишемии;

- травма с первичным или вторичным некрозом мягкотканого массива;

- различные формы местной и общей хирургической инфекции;

- нарушение природных механизмов детоксикации в обеспечении естественных метаболических процессов [Зубовская Е. Т., Колб В. Г., 1994; Ерюхин И. А., Гаврилин С. В., Немченко Н. С. и др., 2001].

Одним из неспецифических интегративных показателей ЭИ являются вещества, или молекулы, средней молекулярной массы (МСМ). А. ВааБ с соавторами в 1971 году высказали гипотезу о значении МСМ в патогенезе ЭИ [Галактионов С. Г., В. В. Николайчик, В. М. Цейтин, Л. М. Михнева, 1983]. В качестве биохимического субстрата ЭИ выступают так называемые эндогенные токсические субстанции (ЭТС) [Николайчик В.В., Кирковский В.В., Моин В.М. и др., 1989]. ЭТС - вещества биологического происхождения, которые, накапливаясь во внутренней среде организма выше нормального уровня, оказывают повреждающее действие на органы и системы.

Роль источников ЭТС могут выполнять:

- очаги механического или ишемического повреждения тканей;

- первичные или вторичные инфекционные очаги воспалительной деструкции;

- очаги естественной вегетации микрофлоры в организме (желудочно-кишечный тракт, воздухоносные пути, мочевыводящие пути);

- патологически функционирующие эндокринные органы;

- все ткани организма в условиях гипоксии [Ерюхин И. А., Насонкин О. С., Шашков Б. В., Лебедев В. Ф., 1989].

Патофизиологическая классификация ЭТС:

1. Конечные и промежуточные продукты нормального обмена веществ (углекислота, лактат, пируват, мочевина, креатинин, мочевая кислота, ароматические аминокислоты, билирубин, неэстерифицированные жирные кислоты). 
2. Конечные и промежуточные продукты извращенного обмена веществ (спирты, альдегиды, кетоны, карбоновые кислоты).

3. Компоненты жидкостных полостных сред (фенол, индол, скатол).

4. Продукты жизнедеятельности микрофлоры в очагах инфекции.

5. Цитолокализованные вещества (трипсин, липазы, аминотрансферазы, лизосомальные ферменты, катионные белки, миоглобин, гемоглобин).

6. Иммунологически чужеродные продукты неограниченного протеолиза плазменных белков, белков тканей и микроорганизмов, продукты распада клеточных мембран.

7. Эффекторные субстанции регуляторных систем организма и их миметики (биологические амины, нейромедиаторы, тиреоидные и стероидные гормоны, антитела и иммунные комплексы, факторы свертывающей системы крови, калликреинкининовой системы и продукты их активации) [Леонтьева Н. В., Белоцерковский М. В., 1998; Малахова М. Я., 2000].

Пул МСМ принято разделять на вещества низкой и средней молекулярной массы вещества в основном небелкового происхождения, и олигопептиды - пептиды с молекулярной массой не более 10-15 КД. Олигопептидная составляющая включает в себя регуляторные и нерегуляторные пептиды.

Регуляторные пептиды - гормоны, играющие важную роль в процессе жизнедеятельности, в обеспечении гомеостаза и патогенезе различных заболеваний. Среди них выявлены нейротензины, нейрокинины, вазоинтестинальный пептид, соматостатин, соматомедин, вещество Р, эндорфины, энкефалины и другие. Концентрация регуляторных пептидов в норме невелика и строго контролируется. Нерегуляторные пептиды - биологически активные вещества, поступившие в организм извне (бактериальные, кишечные токсины) или образовавшиеся в самом организме (в результате аутолиза, ишемии, гипоксии, неограниченного протеолиза). Наиболее обширную группу идентифицированных пептидов составляют фрагменты коллагена и фибриногена и других белков плазмы крови. Они обладают сильными основными свойствами, способностью к агрегации и образованию прочных комплексов с альбумином [Малахова М.Я., 2000].

Травматический токсикоз - достаточно частое явление, характерное для механических травм [Повзун С.А., 1991]. Острый травматический токсикоз характеризуется первичной активизацией свободно-радикальных процессов и последующим высвобождением протеолитических ферментов, чему способствует ацидоз и интенсификация перекисного окисления мембранных фосфолипидов. Нарушение целостности биомембран приводит к прорыву гистогематического барьера с проникновением в плазму, а затем и в почки, продуктов перекисного окисления липидов [А.Ю. Дубикайтис, 1993]. В результате ухудшения тканевой перфузии и действия ЭТС на окислительно-восстановительные процессы развивается гипоксия тканей [Border J.R., Hasset J.M., Leutenegger A.F. et al., 1990; Ronzoni G., Carli F., 1992; Немченко Н.С., Гончаров А.В., Борисов М.Б., 2001]. Помимо этого, пигменты, гемоглобин и миоглобин, высвобождающиеся из поврежденных кровяных и мышечных клеток, являются второй по значимости после лекарств причиной возникновения нефротоксической ОПН [Двойнин Л.А., 1971; Гуманенко Е.К., Бояринцев В.В., Супрун Т.Ю., 1999; Тареева И.Е., 2000].

Выделяют следующие механизмы развития синдрома эндогенной интоксикации: 
1. Ретенционный, который возникает вследствие затруднения выведения и задержки конечных продуктов метаболизма.

2. Обменный, который наступает вследствие нарушения обмена и накопления в организме промежуточных продуктов в избыточном количестве, что приводит к их токсическому действию.

3. Резорбционный, который обусловлен образованием и всасыванием продуктов тканевого распада.

4. Инфекционный, который наступает при гнойно-воспалительных процессах, когда уже трудно дифференцировать влияние на организм продуктов тканевого распада [Рыбачков В.В., Малофеева Э.В., Андреев И.А. и др., 1986; Леонтьева Н.В., Белоцерковский М. В., 1998].

Эндотоксикоз протекает как каскадный процесс, каждая ступень которого отражает степень повреждения органов и тканей и развитие компенсаторных реакций организма. Выделяют пять стадий эндотоксикоза [Малахова М.Я., 2000; Субботин А.В., Чебаненко Н.В., Зинчук С.Ф., 2001].

«Нулевая» стадия носит в основном реактивно-токсический характер [Дубикайтис А.Ю., 1993]. ЭТС поступают в интерстициальную жидкость, кровь, лимфу из очага воспаления или невоспалительной тканевой деструкции, зоны травмированных тканей, из естественной или патологической полости, неадекватно функционирующей эндокринной железы. Клинические проявления эндотоксикоза пока отсутствуют, так как детоксикационные системы окружающих очаг повреждения тканей, крови и лимфы в состоянии временно предотвратить накопление ЭТС выше границы меры. Эндотоксикоз проявляется включением адаптационных нейро-гуморальных реакций (стресс), увеличением объема интерстициальной жидкости, стимуляцией органов физиологической системы детоксикации.

Стадия накопления продуктов первичного аффекта. С током крови и лимфы ЭТС распространяются во внутренней среде организма. При недостаточности защитных и регуляторных реакций, эти вещества начинают накапливаться. В эту стадию можно обнаружить нарастание уровня ЭТС в биологических жидкостях организма, но еще не проявляются нарушения со стороны органов функциональной системы детоксикации [Есаян А.М. и др., 1997].

Стадия декомпенсации регуляторных систем и аутоагрессии. Характерно напряжение и последующее истощение функций гистогематических барьеров, возникновение таких системных реакций организма, как избыточная активация системы гемостаза, калликреинкининовой системы, процессов перекисного окисления липидов, неадекватных и аутоагрессивных иммунных реакций. Это способствует расширению источников аутоагрессии и нарастанию ЭИ. На фоне декомпенсации регуляторных систем и аутоагрессии происходит образование избытка продуктов деградации фибрина и фибриногена, комплексов гепарина с тромбогенными белками и фибронектином, кининов, продуктов активации системы комплемента, перекисного окисления липидов, циркулирующих иммунных комплексов и МСМ. На внутриклеточном уровне действие ЭТС проявляется дисфункцией клеточных органелл, повреждением клеточных мембран и цитолизом. Это ведет к появлению во внутренней среде организма цитолокализованных веществ в качестве новых ЭТС. В наиболее тяжелых случаях эндотоксикоза его стремительное развитие приводит к переходу из фазы декомпенсации регуляторных систем и аутоагрессии сразу в последнюю, необратимую стадию острого эндотоксикоза стадию дезинтеграции организма как биологического целого. 
Стадия извращения метаболизма и гомеостатической несостоятельности. Эта стадия становится основой развития полиорганной несостоятельности, что и определяет исход ЭИ. На этой стадии различные клинические варианты течения эндотоксикоза приобретают сходные клинические проявления.

Стадия дезинтеграции организма как биологического целого. На последней стадии острого эндотоксикоза происходит разрушение функциональных межсистемных взаимосвязей и гибель организма. Повышение проницаемости гистогематических барьеров и нарушения процессов информационного обмена приводят к дезинтеграции организма как единого биологического целого при полной безуспешности на этой стадии мероприятий активной детоксикации. Нарушения информационного обмена в этот период времени связаны с избытком разнородных переносчиков информации (нейромедиаторы, гормоны и другие биологически активные вещества), воздействующих на клеточные рецепторы. При этом клетки теряют способность реагировать на поступающие сигналы и переходят на автономный режим, который не обеспечивает согласованное выполнение специфических функций (синтез медиаторов и гормонов, транспортных белков, компонентов системы гемостаза и комплемента, синтез гликокаликса и сурфактанта, конъюгация билирубина, синтез мочевины и многие другие) [Дубикайтис А.Ю., 1993; Девятова Т.А., Шляхов В.И., Аранович А.М., Чакушин Б.Э., 2000].

Хронический эндотоксикоз - патологический процесс, при котором поддержание гомеостаза и, следовательно, жизнеспособность организма достигается вследствие развития компенсаторных механизмов. Он характеризуется накоплением в крови малотоксичных веществ, включая метаболиты. При хроническом эндотоксикозе не происходит фатальных нарушений гомеостаза, но избыточная активность систем детоксикации в течение длительного времени приводит к их постепенному истощению и снижению резистентности и реактивности организма к повреждающим факторам внешней и внутренней среды. На поздних этапах процесс утрачивает связь с первичной причиной, и вступают в силу универсальные патогенетические закономерности, связанные с системной тканевой гипоксией [И.А. Ерюхин, О.С. Насонкин, Б.В. Шашков, В.Ф. Лебедев, 1989].

Мониторинг показателей интоксикации является важным не только для оценки ее степени и динамики, но и критерием подбора профилактических мероприятий с целью предотвращения различных осложнений и хронических заболеваний возникающих у людей, в развитии которых важнейшую роль играет эндогенная интоксикация.

Таким образом, проведенный анализ литературных данных показал, что изменения процессов метаболизма, возникающие в ответ на различные внешние воздействия, носят неспецифический характер и зависят от силы раздражителя. При этом недостаточно изученными остаются ответные реакции организма, развивающиеся в результате сочетанных травми политравмы на фоне долговременного влияния физических факторов окружающей среды.

Это связано с тем, что после травмы ЦНС развиваются вторичные патологические изменения головного мозга, которые значительно расширяют объем первичного повреждения в посттравматическом периоде. Все происходит это на фоне системных нарушений гемостаза, внешнего дыхания и гемодинамики и делает прогноз полноценного восстановления и реабилитации людей неблагоприятным даже после легкой черепномозговой травмы.

Изменения в белковом обмене затрагивали более $60 \%$ обследуемых. Так, снижение относительно физиологической нормы содержания общего белка и альбуминов в сыворотке крови отмечалось у 60,5\% и 67,3\% пациентов соответственно. Гипоальбуминемия, 
сопровождалась относительной гиперглобулинемией, преимущественно за счет повышения доли фракций острофазовых белков - $\alpha_{1}$-глобулинов и $\alpha_{2}$-глобулинов, соответственно у $68,6 \%$ и 57,1\%. Доля фракции $\gamma$-глобулинов была выше нормы у $11,3 \%$ людей, у остальных она находилась на нижней границе, а фракция $\beta$-глобулинов была в пределах нормальных физиологических значений.

У четверти обследуемых содержание мочевины и у 12,5\% концентрация билирубина в сыворотке крови было выше физиологической нормы (у 7,7\% - ниже нормы).

Концентрация креатинина в сыворотке крови у подавляющего большинства людей находилась в пределах нормальных физиологических значений.

Среди показателей водно-минерального обмена наиболее значительные изменения были характерны для уровня общего кальция. У 64,4\% пострадавших отмечалось пониженное содержание кальция в сыворотке крови. Изменения других показателей содержания электролитов в сыворотке крови были менее существенные, оставаясь у подавляющего большинства людей в пределах нормальных физиологических значений. Однако, у $12 \%$ людей отмечалось сниженное относительно физиологической нормы содержание фосфата неорганического и натрия в сыворотке крови. При этом, количественные значения показателей хлоридов и натрия лишь незначительно выходили за пределы нормальных физиологических колебаний.

Изменения показателей липидного обмена характеризовались смещением распределения значений холестерина в сторону более низких концентраций (у $28,4 \%$ обследованных), в то время как концентрация триглицеридов у 18,3\% людей была выше нормы.

У подавляющего большинства пострадавших повышалась активность ферментов. АСТазная и АЛТ-азная активности в сыворотке крови превышали пределы физиологической нормы у 84,5\% пострадавших, креатинкиназная и катепсина Д активности - у 70 и более процентов обследованных. Превышекния активности амилазы и кислой фосфатазы были менее выражены (у 15\% обследуемых).

Наиболее стабильными параметрами внутренней среды организма и наименее информативными в условиях Крайнего Севера являются показатели водно-солевого обмена, величины которых колеблются очень незначительно. Самая высокая информативность характерна для показателей активности ферментов.

Исследования сыворотки крови, проведенные в острый период сочетанной травмы показали, что перестраиваются все звенья метаболизма, выражаясь в изменении показателей белкового, углеводного, липидного обмена сыворотки крови. Исследование белков сыворотки крови пострадавших показало, что достоверное изменение уровня общего белка наблюдалось на 3 - 4 сутки после травмы; его содержание падало до 62,0土 1,33 г/л, и оставалось сниженным до восьмых суток.

Сопоставление результатов динамики изменения уровня общего белка и альбуминов дает возможность предположить, что уменьшение концентрации общего белка были связаны, прежде всего, с изменением концентрации альбуминов в сыворотке крови. Представляет интерес снижение альбумино-глобулинового коэффициента в зависимости от степени повреждения головного мозга: в группе пациентов с сотрясением головного мозга (СГМ) спустя 30 суток после травмы происходит нормализация этого показателя, тогда как у пациентов с ушибом головного мозга (УГМ) обнаружено снижение коэффициента альбумины/глобулины за счет повышения фракции глобулинов и в более отдаленные сроки наблюдения.

Максимальное повышение $\alpha$ - и $\beta$-глобулинов наблюдали на 3 - 4 сутки после травмы. Более выраженное увеличение фракции $\alpha_{1}$-глобулинов после операции наблюдалось в 
группе с СГМ, но для них же характерна более быстрая динамика восстановления нормальных величин белковых фракций.

Результаты проведенных исследования свидетельствуют о более глубоких изменениях белкового метаболизма у пациентов с УГМ, что обусловливается, по-видимому, более существенными катаболическими нарушениями и негативным влиянием ЧМТ на функционирование детоксикационных систем. Выполненные исследования показали, что наиболее ранимой функцией печени является биосинтез мочевины. При этом наиболее значимые изменения данного показателя наблюдались у больных в срок 18 - 20 суток после травмы, выраженным снижением биосинтеза мочевины. Необходимо отметить, что у больных с более тяжелой ЧМТ, указанные изменения крови оставались и в срок 45 суток после травмы.

Таким образом, выше изложенный материал позволяет отметить одну особенность: в острый период сотрясения и ушиба головного мозга в организме проявляется выраженная тенденция к задержке азота, связанная, вероятно, с ростом катаболических реакций белкового и пуринового обмена.

При исследовании динамики изменения показателей углеводного нами обнаружено, что сочетанная травма вызывала подъем уровня глюкозы в сыворотке крови. Отмечался рост ее концентрации в течение первых суток после операции, с достижением максимальных

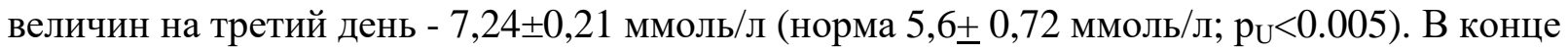
острого периода (18-21 день) содержание глюкозы в крови людей этой группы достоверно от референтных значений не отличалось, однако на этом этапе отмечался рост степени варьирования ее концентрации в крови $\left(\mathrm{p}_{\mathrm{F}}<0.05\right)$. К 40 - 45 суткам ее концентрация

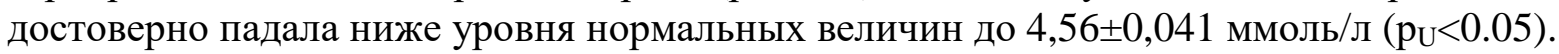
Обнаруженное к концу восстановительного периода снижение концентрации глюкозы носило функциональный характер и объясняется истощением запасов источников глюкозы в организме, причем высокая вариативность значений в эти сроки свидетельствует также о том, что такие изменения носят общий характер и не зависят от индивидуальных особенностей пострадавших.

Изменение содержания продуктов гликолиза показало, что в крови людей происходило накопление молочной кислоты, ее уровень к третьим суткам достигал максимального для всех этапов значения в группе людей с более тяжелой травмой - 3,18 $\pm 0,51$ ммоль/л при норме $1,80 \pm 0,10$ ммоль/л $\left(p_{U}<0.05\right)$. При этом концентрация пировиноградной кислоты в ранний посттравматический период в обоих группах достоверно не отличалась от значений референтной группы. Возрастало и соотношение МК/ПВК, с максимумом на

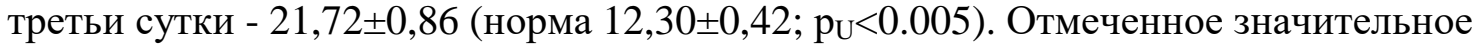
накопление МК в крови, свидетельствовало о преобладании в организме анаэробных процессов. При этом высокая степень варьирования значений МК и ПВК позволяет заключить, что изменения процессов энергообеспечения, связанные с ответной реакцией организма на ЧМТ, сугубо индивидуальны, но носят ярко выраженную направленность в сторону преобладания анаэробных процессов генерации энергии.

Исследование динамики изменения электролитов в сыворотке крови показало, что уровень общего кальция, хлорид иона и магния изменялись не существенно. Статистически значимые различия нами были отмечены для значений неорганического фосфора. Нами было выявлено повышение концентрации К почти в 1,5 раза. Одновременно с увеличением концентрации К в сыворотке крови $27 \%$ людей происходило незначительное, но достоверное увеличение концентрации ионов натрия. Натрий является основным катионом внеклеточной жидкости, его основная физиологическая роль состоит в поддержании осмотического давления и $\mathrm{pH}$ во внутри- и внеклеточных пространствах [Крестинская Т.В., Наточин Ю.В.,1961; Берхин Е.Б., Иванов Ю.И., 1972; Зуфаров К.А., Гонтмахер В.М., 1984]. Почечный механизм регуляции натрия 
является самым важным фактором в поддержании концентрации натрия в плазме. Как правило причины гипернатриемии связаны с нарушением функции почек [Рябов С.М., Наточин Ю.В., 1997; Yamakawa M., Katou T. et al, 2004].

Для определения влияния сочетанной травмы на функционирование всех систем организма были изучены содержание эндогенных токсических субстанций и интегральные индексы интоксикации, а также проведено сравнение показателей плазмы крови и содержание их в эритроцитах больных с референтными значениями. На четвертые сутки поступления в клинику больные обследуемых групп не имели значимых различий в степени эндогенной интоксикации. У всех людей помимо повышенного уровня ВНСММп, отмечалось повышение величины катаболического пула плазмы и нормальная величина катаболического пула эритроцитов, распределение токсинов смещалось в сторону плазмы. Таким образом, токсины, образующиеся после травмы и оперативного вмешательства в увеличенном количестве, накапливались в плазме, не оседая на поверхности эритроцитов и не изменяя общего уровня интоксикации. То есть на четвертые сутки после травмы наблюдалась умеренной степени интоксикация, которая не зависела от тяжести травмы.

Однако на 8-е сутки нахождения в клинике у больных с тяжелыми повреждениями ЦНС (ушиб головного мозга) помимо повышенного содержания ВНСММп, отмечалось увеличение концентрации ВНСММэр, продолжала нарастать величина катаболического пула плазмы. Значительно увеличивались значения индекса токсичности плазмы и индекса интоксикации. Равновесие концентраций ЭТС в биологических средах резко смещалось в сторону преобладания их в плазме. Такая картина наблюдалась вплоть до 40 - 45 дня после травмы.

Таким образом, представленные выше данные позволяют использовать значения сывороточных показателей в качестве биохимических тестов, отражающих степень повреждения тканевого метаболизма. Среди изученных показателей для оценки тяжести сочетанной травмы нами предлагается использовать определение активности КК, АсАТ, АлАТ, общего белка, альбумина и процента катаболического пула ВНСММ плазмы, что позволит выявить глубину метаболических расстройств в организме пациента. 


\section{ГЛАВА 2.}

\section{БИОСОВМЕСТИМЫЕ ИМПЛАНТАТЫ В ТРАВМАТОЛОГИИ}

В развитых странах на фоне непрерывного роста травматизма и заболеваемости костно-мышечной системы наблюдается и развитии медицинских технологий, направленных на создание новых органов и тканей, заменяющих поврежденные, - кожные покровы, мышечную ткань, кровеносные сосуды, нервные волокна, костную ткань. Такие материалы получили название биоматериалов. «Биоматериалы - это материалы, предназначенные для того, чтобы служить границей раздела с биологическими системами, для того чтобы оценивать, лечить, наращивать или заменять любую ткань, орган или функцию тела» [Williams D.F., 1992].

За последние 30-40 лет в медицине использовалась масса различных материалов (металлы, керамика, полимеры) для лечения, восстановления и замены более 40 различных частей человеческого тела. Наиболее успешно эта работа проводится при лечении патологии костно-мышечной системы, чему способствовало развитие индустрии эндопротезирования крупных суставов. Данную область современного материаловедения называют еще биокерамикой, подчеркивая ведущее значение керамической составляющей в используемых имплантатах для эндопротезирования, в пломбировочных материалах для стоматологии, в имплантатах для челюстно-лицевой хирургии, в медико-косметических средствах [Hench L.L., 1998; Suchanek W., Yoshimura M., 1998]. Число больных, нуждающихся в операциях по восстановлению целостности кости, довольно велико: для России или США эта цифра составляет более 1 млн человек ежегодно (из них 200-300 тыс. - протезирование тазобедренного и коленного суставов).

Биоматериалы должны обладать определенными химическими свойствами (отсутствие нежелательных химических реакций с тканями и межтканевыми жидкостями, отсутствие коррозии), механическими характеристиками (прочность, стойкость к образованию трещин, сопротивление замедленному разрушению, износостойкость), биологическими свойствами (отсутствие реакций со стороны иммунной системы, консолидация с костной тканью, стимулирование остеогенеза).

Биоматериалы, которые используют в качестве имплантатов, заменяющих кость (эндопротезы), или в качестве временных фиксаторов для сломанной кости (накостные пластины, интрамедуллярные стержни), оценивают и по активности влияния на репаративную способность последней:

- биотолерантные материалы (нержавеющая сталь и кобальтохромовые сплавы) поверхность таких имплантатов отделяется от смежной кости слоем фиброзной 
ткани, репаративная регенерация поврежденной кости происходит в обычные сроки и на некотором расстоянии от имплантата (дистантный остеогенез);

- биоинертные материалы (оксиды титана и алюминия) - не вызывают образования фиброзной ткани, репаративный остеогенез протекает в непосредственном контакте с поверхностью имплантата, но консолидация происходит в обычные сроки;

- биоактивные материалы (кальций-фосфатная керамика и биостекла на основе кремния) - характеризуются образованием очень тесной химической связи с костью (связующий остеогенез), усиливают реакции образования костной ткани начиная с поверхности имплантата и индуцируют образование непрерывной связи от ткани к его поверхности.

Широкое распространение метода оперативного лечения переломов и заболеваний костной системы обусловлено развитием асептики и антисептики и прежде всего, конечно, появлением антибиотиков. Предложены внутренние (внутрикостные и накостные) и наружные (спицевые и стержневые) фиксаторы для обеспечения максимально надежного остеосинтеза сломанной кости.

Известно, что для сращения переломов, для поддержания репаративной регенерации костной ткани должен соблюдаться ряд условий:

• полная репозиция костных отломков;

- стабильная фиксация костных фрагментов;

- сберегательное отношение к остеогенным тканям;

• хорошее кровоснабжение оперированной конечности;

- возможность функционального использования конечности с первых дней после операции.

Все эти условия в большей или меньшей степени стремяться выполнять все современные технологии остеосинтеза (накостные, внутрикостные, чрескостные]. Имплантаты изготавливают из прочных металлов и сплавов. Тем не менее клиническая практика показывает, что время консолидации перелома практически не изменилось за последние 100 лет, к полной нагрузке при остеосинтезе приступают не ранее 4-6 месяцев, а период нетрудоспособности достигает 10-12 месяцев даже при положительном исходе. Одна из причин этого - отсутствие биоактивных металлов, которые бы ускоряли репаративный остеогенез.

К типичным представителям биоактивных материалов относятся биостекла (наиболее часто используется состав: 24,5\% $\mathrm{Na}_{2} \mathrm{O}, 24,5 \% \mathrm{CaO}, 45,0 \% \mathrm{SiO}_{2}, 6 \% \mathrm{P}_{2} \mathrm{O}_{5}$; варьируя состав, можно изменять их биоактивность и резорбируемость) и материалы на основе 
гидроксиапатита - $\mathrm{Ca}_{10}\left(\mathrm{PO}_{4}\right)_{6}(\mathrm{OH})_{2}$ (плотная и пористая керамика; композиты «гидроксиапатит - полимер). Однако подобные биоактивные материалы отличает хрупкость и в чистом виде они значительно уступают по прочности металлическим. Выход был найден в производстве металлических имплантатов с гидроксиапатитовым покрытием [Карлов А.В., Шахов В.П. , 2001; Твердохлебов С.И. с соавт., 2012].

\section{1. Механизмы консолидации переломов.}

Сращение переломов, консолидация костных фрагментов напрямую связана с процессом регенерации - восстановлением организмом утраченных или поврежденных органов и тканей (Советский энциклопедический словарь, 1982). Такая формулировка данного процесса повторяется с разной степенью точности практически во всех источниках.

Описывая анатомическое и функциональное восстановление поврежденных тканей обычно выделяют понятие репаративной регенерации. Регенерация репаративная регенерация участков органов или тканей, погибших в результате какого-либо патологического процесса (Энциклопедический словарь медицинских терминов, 1984).

Степень полноты репаративной регенерации определяется двумя основными факторами: 1) регенерационной потенцией ткани и 2) объемом дефекта.

В отношении костной ткани следует отметить ее значительный регенерационный потенциал, связанный с уровнем обменных процессов, сравнимым с таким органом, как печень. В основе костного вещества лежит соединительная ткань, обладающая чрезвычайно высокой пластичностью. Ретикулярная ткань, которая заполняет костномозговой канал, также обладает высокой пластичностью. Потому любая травма, будучи пластическим раздражителем, вызывает и стимулирует рост этих тканей.

При гибели сложных структурных комплексов, к которым относится и кость, восстановление утраченной ткани идет из особых участков органа, являющихся своеобразными центрами регенерации. Для кости до недавнего времени таким центром считалась надкостница. Однако многочисленные исследования отечественных ученых на экспериментальном и клиническом материале доказали огромные пластические возможности эндоста и костного мозга в процессе восстановления целостности поврежденной кости. Установлено, что в процессе репаративного костеобразования ведущая роль принадлежит камбиальным элементам эндоста при относительно слабой реакции со стороны периоста и параоссальных тканей. Именно за счет эндостальных элементов устанавливается связь между отломками и соединительнотканным регенератом [Илизаров Г.А., 1986; Шрейнер А.А., 1995].

В большинстве учебников и монографий заживление перелома кости делят на три периода или фазы: воспалительную, репаративную и фазу реконструкции. 
Повреждение кровеносных сосудов кости приводит к нарушению питания остеоцитов в месте перелома и они погибают. С образованием некротической ткани по краям фрагментов (Рис. 2.1 а) развивается реактивное воспаление по периферии. Этот приспособительный акт, сопровождающийся гиперемией и повышением тканевого метаболизма, способствует ускоренной дифференцировке остеогенных клеток и формированию соединительной ткани.

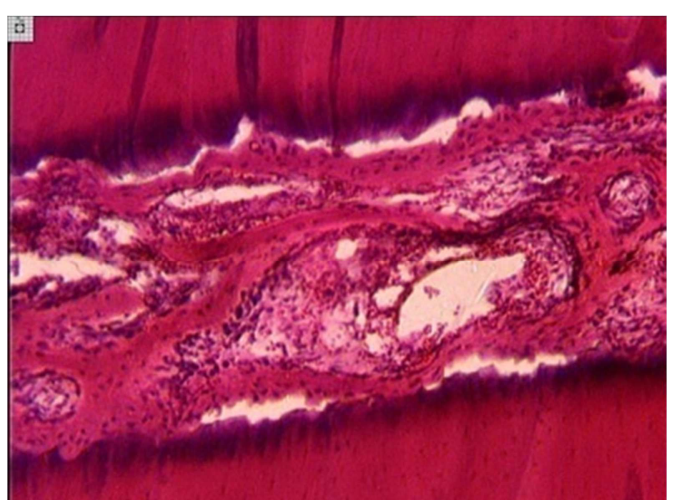

Рис.2.1. Микрофото межотломкового пространства в интермедиарной области после перелома голени собаки через 14 суток классического остеосинтеза по Илизарову (края костных фрагментов некротизированы, интермедиарное пространство заполнено грубоволокнистой тканью).

Между костными фрагментами при повреждении кости, будь то травма или оперативное вмешательство, всегда образуется гематома, которая вскоре замещается грануляционной тканью во второй репаративной фазе и здесь задача врача-травматолога регулировать процесс регенерации в сторону оссификации морфологических структур, формирующихся между костными фрагментами.

В фазу реконструкции заживающий перелом приобретает прочность. Кость начинает приобретать трабекулярное строение и впервые отмечается активность остеокластов, которые по мере изменения нагрузки на кость, восстановления функции конечности расщепляют хаотично расположенные трабекулы и оставляют только те из них, которые концентрируются по векторам нагрузки и давления.

Помимо регенерационной потенции кости, степени и характера повреждения, важную роль играют и общие факторы. К ним относятся возраст пациента, характер и особенности его питания, общая реактивность организма, наличие трофических нарушений, авитаминоз и др.

Огромное значение для исхода перелома имеют и условия, которые создаются в процессе лечения. К местным условиям, влияющим на процессы регенерации кости, относят степень репозиции отломков и их иммобилизацию, наличие элементов дополнительной фиксации и ее характер. Недопустимо, чтобы дополнительная фиксация костных отломков (накостный или внутрикостный остеосинтез) усугубляла степень травматизации кости и нарушения кровообращения. При нарушении местных условий 
регенерации кости, отсутствии репозиции и достаточной иммобилизации, тяжелых переломах с нарушениями кровоснабжения происходит вторичное костное сращение с образованием между костными отломками хрящевой ткани, на основе которой в последующем строится костная ткань. Поэтому при вторичном костном сращении говорят о предварительной костно-хрящевой мозоли, которая в последующем превращается в зрелую кость (рис. 2.2).

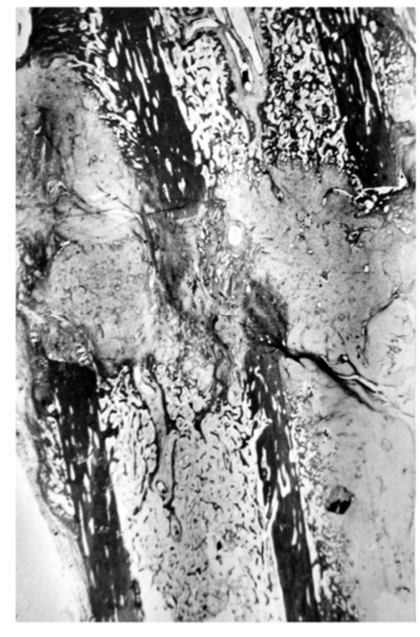

$a$

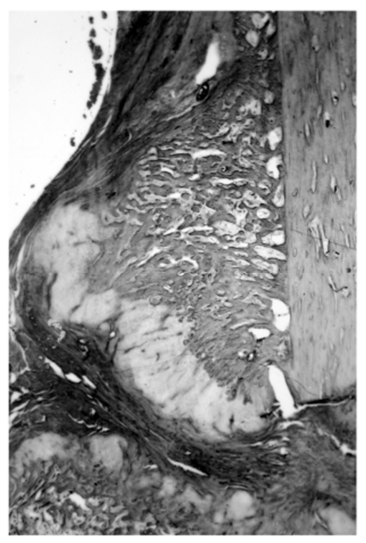

6

Рис. 2.2. Полное смещение костных отломков: $a-$ замещение диастаза хрящевой тканью; $\sigma-$ костнохрящевые напластования на поверхности отломка. х10. Окраска гематоксилин-эозином.

Осложнения при заживлении переломов могут заключаться прежде всего в замедлении консолидации и несращении.

Временн'ые характеристики процесса заживления при оптимальных условиях зависят от вида кости и возраста пациента. H. Ellis еще в 1958 г. показал, что в возрасте до 16 лет нет необходимости более чем в 12-недельной иммобилизации, тогда как у пациентов старшего возраста срок иммобилизации колеблется от 15-ти до 20-ти недель. О.Н. Collins в 1966 г. [цит. по: Ревел П.А., 1993] привел оптимальные сроки формирования костной мозоли при переломах (табл. 2.1).

Таблица 2.1. Временн'ые характеристики заживления переломов (по О.Н. Collins, 1966)

\begin{tabular}{|l|c|}
\hline $\begin{array}{c}\text { Время после } \\
\text { травмы }\end{array}$ & Гистологическое содержимое зоны перелома \\
\hline 12 часов & Сгустки крови и экссудат между фрагментами \\
\hline
\end{tabular}




\begin{tabular}{|l|l|}
\hline 24 часа & $\begin{array}{l}\text { Острое воспаление с миграцией полиморфноядерных лейкоцитов и } \\
\text { макрофагов }\end{array}$ \\
\hline 48 часов & Формирование грануляций \\
\hline 5 суток & Раннее костеобразование \\
\hline 7 суток & Пустые остеоцитарные лакуны на концах костных фрагментов \\
\hline 3 недели & Фиброзное сращение; небольшая первичная мозоль \\
\hline 6 недель & $\begin{array}{l}\text { Периостальная оболочка наружной мозоли; завершенная } \\
\text { грубоволокнистая костная мозоль }\end{array}$ \\
\hline $\begin{array}{l}\text { После 6-ти } \\
\text { недель }\end{array}$ & $\begin{array}{l}\text { Прогрессирующее образование вторичной мозоли и последующая ее } \\
\text { реконструкция }\end{array}$ \\
\hline
\end{tabular}

Острое асептическое воспаление в месте перелома длится 24-48 часов и сопровождается экссудацией и миграцией полиморфноядерных лейкоцитов, а затем макрофагов; процесс впоследствии переходит в фазу заживления с формированием грануляционной ткани и пролиферацией мелких кровеносных сосудов, а также миграцией фибробластов в эту область. Процесс первичного костного сращения начинается с врастания в область гематомы между костными отломками молодых мезенхимальных элементов и сосудов. Скорость последующего развития фиброзной ткани между концами кости или предварительной соединительнотканной мозоли зависит от местных условий, в оптимальном варианте фиброзное сращение происходит примерно через 2 недели. В этот же период сразу начинается образование кости. Оно связано с активацией и пролиферацией молодых недифференцированных остеогенных клеток в зоне повреждения. Эти клетки называют камбиальными, стволовыми клетками и клеткамипредшественниками. В фазу дифференцировки молодые клетки созревают, происходит, например, структурно-функциональная специализация остеобластов.

Превращение грануляционной ткани в грубоволокнистую означает образование костной мозоли. Понятие «первичная мозоль» используют для обозначения вновь сформированной грубоволокнистой кости, образованной первоначально. Резорбция этой примитивной кости и формирование пластинчатой костной ткани означают развитие окончательной мозоли, приводящее к образованию плотного костного соединения в месте перелома. По своему строению эта костная мозоль отличается от костной ткани только беспорядочным расположением костных балок. Последующая реконструкция идет под влиянием таких факторов, как механическая нагрузка, связанная с возобновлением нормальной двигательной активности пациента.

Сложность перелома и степень смещения фрагментов кости, без сомнения, влияют на скорость заживления, поэтому основными оптимальными условиями для обеспечения сращения в наиболее короткие сроки являются полная репозиция отломков и их 
стабильная фиксация, восстановление кровоснабжения костных фрагментов и возможность функциональной нагрузки конечности с первых дней после операции. В настоящее время наилучшим образом эти условия обеспечиваются с помощью метода внешней фиксации аппаратом Илизарова. Еще 1972 г. сам автор наблюдал наличие первичного костного сращения при диафизарных переломах кости к 21-30-му дню, метафизарный перелом должен срастаться, по его мнению, через 2 недели.

В 1976 г. И.А. Имерлишвили в отчете об экспериментальной работе отмечал, что формирование интермедиарной костной мозоли при компрессионном остосинтезе осуществлялось по десмальному типу остеогенеза. Этому предшествовала резорбция концов костных отломков остеокластами и врастание в образующиеся лакуны скелетогенной ткани со стороны костномозгового канала. Начальные признаки формирования интермедиарной костной мозоли появлялись к концу 2-й недели эксперимента. К 30-му дню отломки оказывались спаянными костной интермедиарной мозолью. На протяжении 2-го месяца в зоне остеотомии отмечались активно текущие перестроечные процессы, в результате которых происходило замещение грубоволокнистой костной ткани пластинчатой. Эти реконструктивные процессы, связанные с функциональными возможностями конечности, продолжались в течение нескольких месяцев.

К сожалению, в клинической практике подобные случаи быстрого сращений перелома, даже при использовании аппарата Илизарова, наблюдаются очень редко. Современные учебники по травматологии указывают средние сроки сращения, например, костей голени в 3-4 месяца [Юмашев Г.С., 1990; Анкин Л.Н., Анкин Н.Л., 2005]. Важную роль в процессе сращения играет не только наличие репозиции и стабильной фиксации, но и поддержание компрессионных усилий на стыке отломков. Например, при стабильном, но нейтральном остеосинтезе наблюдается аналогичный процесс костеобразования, который протекает в более растянутые сроки, характеризуясь меньшей активностью. Следовательно, с целью сокращения сроков лечения необходимы дополнительные условия для стимуляции репаративного процесса.

Безусловно, не нужно забывать о влиянии на повреждение ткани со стороны нейрогуморальной системы. Глубина нарушения гомеостаза - изменение состава внутренней среды организма, ферментной констелляции сыворотки крови, уровней почечной экскреции электролитов и органических веществ, клеточного состава периферической крови - зависит от тяжести повреждения кости и мягких тканей, сопутствующей кровопотери, тяжести местных расстройств кровообращения, возраста больного и его общесоматического здоровья [Герасимов А.М., Фурцева Л.Н., 1986; Барабаш А.П. и др., 1999]. 
Первой реакцией на травму костно-мышечной системы является развитие типичного стресс-синдрома, когда афферентный сигнал из очага повреждения достигает коры головного мозга, лимбико-ретикулярной системы, ядер гипоталамуса. Продукция либеринов в гипоталамусе стимулирует синтез и секрецию в передней доле гипофиза тропинов, определяющих начало гормональной реакции на травму и модулирующих посттравматический эндокринный профиль, ведущим в котором считают резкое увеличение секреции кортикостероидов и катехоламинов - гормонов адаптации [Кассиль Г.Н., 1975; Корнеев Г.Я., 1979; Горизонтов П.Д. и др., 1983; Egdahl R.N. et al., 1977]. Под контролем адаптогенных гормонов происходят изменения во внутренней среде, в химическом и клеточном составе периферической крови [Кулагин Г.Н., 1978; Десятниченко К.C., 1982; Lal S.K. et al., 1976; Egdahl R.N. et al., 1977]. Ocoбое значение для травматологов имеет то обстоятельство, что адаптогенные гормоны, по-видимому, оказывают прямое влияние на усиление синтеза и повышение секреции остеотропных гормонов - паратирина, кальцитонина, соматотропина [Gordan G.S., 1971; S.C. Miller, Jee W.S.S., 1975; Lukert B.P., Adams J.S., 1976; Parfitt A.M., 1977], мишенями действия которых являются клетки, играющие главную роль в резорбции и новообразовании костной ткани (остеокласты и остеобласты). Материальным воплощением функции остеогенных клеток является формирование костной ткани и реконструкция ее структуры - минерализация органического матрикса костной ткани, резорбция костных фрагментов и первичных остеонов.

Изучение гормонального состава плазмы крови у травматологических больных в условиях чрескостного остеосинтеза сотрудником РНЦ «ВТО» Н.В. Офицеровой (1988) показало, что сразу после травмы (3-4 часа) возрастает концентрация адренокортикотропина, альдостерона, кортизола, паратирина. Это гормональный ответ организма на травму. Максимальная концентрация данных гормонов в условиях чрескостного остеосинтеза аппаратом Илизарова наблюдается к 35-му дню после травмы. В дальнейшем, после месяца остеосинтезе, концентрация остеотропных гормонов и интенсивность обменных процессов неизменно снижались. Следовательно, именно в этот период необходимо в основном завершить сращение костных отломков. Если активное формирование костного регенерата продолжается, то нужен способ пролонгированного воздействия на процесс концентрации мезенхимальных клеток-предшественников, их дифференцировку и функциональную активность остеогенных клеток.

Метод интрамедуллярного напряженного армирования [Патент РФ № 2232555, авторы: В.И. Шевцов, А.В. Попков, Д.А. Попков, С.А. Ерофеев] позволяет влиять на активность костного мозга, стимулируя эндостальное костеобразование. 
Клинический пример. Пациент С., 18 лет (рис. 2.3). Травму получил на лесоповале в результате удара бревном. Диагноз: закрытый перелом диафиза левой большеберцовой кости.

Операция: репозиция, остеосинтез аппаратом Илизарова, интрамедуллярный напряженный остеосинтез спицами (хирург Д.А. Попков).

Через 17 дней аппарат Илизарова был снят, и фиксация голени продолжена гипсовым ортезом без иммобилизации смежных суставов. Спустя 1,5 месяца пациент вновь вышел на работу машинистом пилорамы.
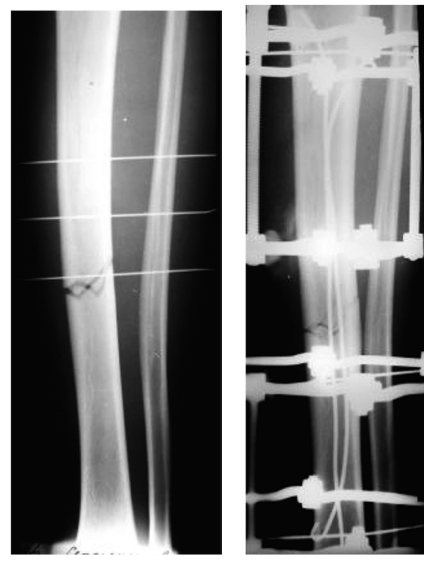

6

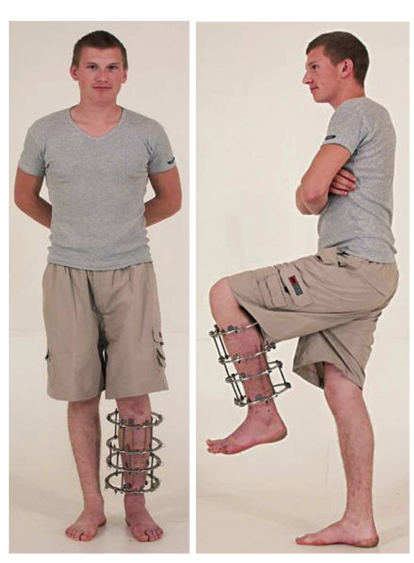

$B$

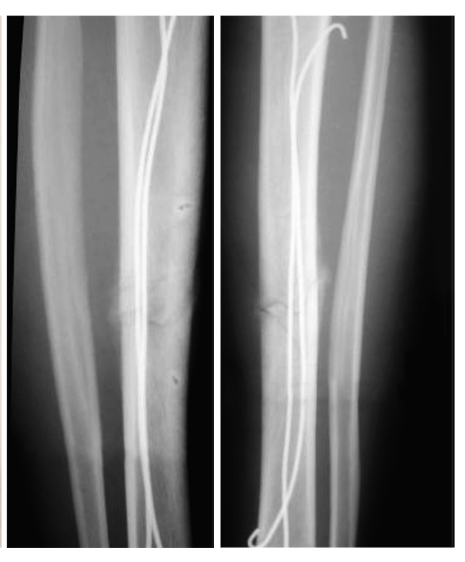

2

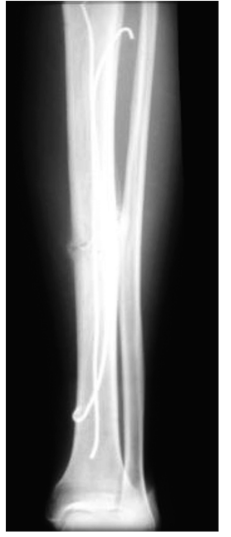

$\partial$

Рис.2.3. Пациент С., 18 лет: а - рентгенограмма костей голени во время скелетного вытяжения на операционном столе; $\sigma-$ рентгенограмма костей голени после операции; 6 - функция нижней конечности во время остеосинтеза; 2 - рентгенограммы костей голени в день демонтажа аппарата Илизарова (17-й день после операции); $\partial$ - рентгенограмма костей голени через 1,5 месяца после демонтажа аппарата Илизарова.

Такое индуцирующее влияние, по-видимому, сохраняется в течение продолжительного времени, до тех пор, пока спица не будет удалена. Данный метод остеоиндукции, кроме того, отличается малой травматичностью и исключает возможность замедленной консолидации, т.е. обеспечивает профилактику формирования ложного сустава и вторичных деформаций кости, а также раннюю функциональную активность пациента. Возможности данного метода лечения переломов мы обсудим в 4 и 5 главах.

\section{2. Методы нанесения кальций-фосфатных покрытий}

Однофазные биоматериалы, каковыми являются современные имплантаты из металлов, не в состоянии обеспечить все необходимые функции костей или других кальцинированных тканей и, следовательно, существует большая потребность в создании многофазных биоматериалов со структурой и составом, имитирующими природную 
кость. Такие материалы относятся к разряду гибридных, которые получают сочетанием химически разнообразных компонентов. Для объединения положительных свойств компонентов гибридной системы необходима интеграция их составляющих в одном материале. К гибридным материалам относят композитные материалы, многослойные системы, частицы, волокна с модифицированной поверхностью, что придает им специальные, к примеру, гидрофобные / гидрофильные свойства. Это направление стало основным путем совершенствования физико-химических свойств и технических характеристик разнообразных материалов, в том числе, медицинского назначения [Маттиас Эппле, 2007; Dorozhkin, 2011]. В частности, в практической медицине в качестве наполнителей и покрытий используют КФ материалы [Dorozhkin, 2009; Агаджанян и др., 2011].

В последние годы для реализации концепции тканевой инженерии, предполагающей стимуляцию регенеративной способности организма хозяина, было разработано много пористых синтетических конструкций, называемых костными скаффолдами (матриксами), которые имитируют сложные физико-химические свойства кости [Lee, Shin, 2007; Bran et al., 2008; Kanczler, Oreffo, 2008]. Использование синтетических полимерных скаффолдов связано с такими их достоинствами, как исключение опасности переноса заболеваний, сокращение опасности инфекции или иммуногенности, а также широкой доступностью материалов для их изготовления и возможностью создания на их основе композитов, наполненных биоактивными веществами. Композитные полимеры можно использоваться и в качестве покрытий имплантатов [Аронов и др., 2010].

Как показывает практика применения имплантатов с модифицированной поверхностью, универсального метода формирования покрытий, подходящего для всех медицинских применений, и покрытия, всецело удовлетворяющего всему комплексу медицинских и технических требований, не существует. Поэтому достичь оптимально возможных результатов можно путем интеграции существующих технологий, совмещающих различные методы, т. е. с помощью гибридных технологий. Такой подход на сегодняшний день является актуальным и перспективным. Группой сотрудников Томского политехнического университета совместно со специалистами ФГУ «РНЦ «ВТО» им. акад. Г.А. Илизарова» развиваются методы получения гибридных материалов для тканевой инженерии на основе интеграции различных технологий нанесения покрытий. За основу взяты следующие базовые технологии формирования покрытий, которые развиваются при активном участии следующих специалистов: микродуговое оксидирование, магнетронное напыление, формирование полимерных покрытий, 
вакуумно-дуговое напыление в условиях короткоимпульсного высокочастотного плазменно-иммерсионного ионного ассистирования.

\subsection{1. Гибридный метод формирования биокомпозитов на поверхности металлических имплантатов на основе микродугового оксидирования.}

Простым, отработанным, экономичным и, следовательно, широко используемым способом получения КФ покрытий на титановых имплантатах, является электрохимические методы, к которым относится микродуговое оксидирование (МДО). Микродуговое оксидирование, известное также как микроплазменное оксидирование или анодно-искровое осаждение, - это процесс модификации (окисления) поверхности вентильных металлов и их сплавов (оксиды которых, полученные электрохимическим путем, обладают униполярной проводимостью в системе металл-оксид-электролит, например, сплавы $\mathrm{Al}, \mathrm{Mg}, \mathrm{Ti}, \mathrm{Zr}, \mathrm{Nb}, \mathrm{Ta}$ и др.) в электролитной плазме. Эта технология предназначена для создания твердых, толстых оксидных покрытий на металлических подложках, в первую очередь, титановых имплантатах. Процесс МДО значительно увеличивает твердость, которая постепенно возрастает от поверхности к внутренним областям покрытия, согласуясь с вариациями фракции $\mathrm{TiO}_{2}$ вдоль толщины покрытия. Кинетика нанесения МДО покрытий управляется границей раздела и в значительной степени зависит от приложенной силы тока и времени обработки [Rama Krishna et al., 2003; Liang et al., 2007].

Толщина покрытий, получаемых в дуговом режиме, порядка 20-40 мкм, пористость 20-30\%, размер пор 5-7 мкм. Типичная морфология поверхности таких покрытий приведена на рис. 2.4.

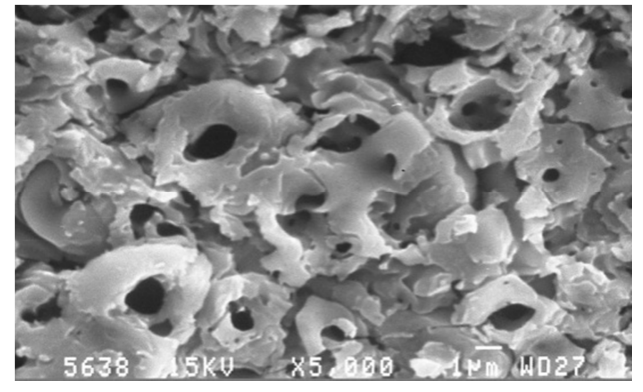

a

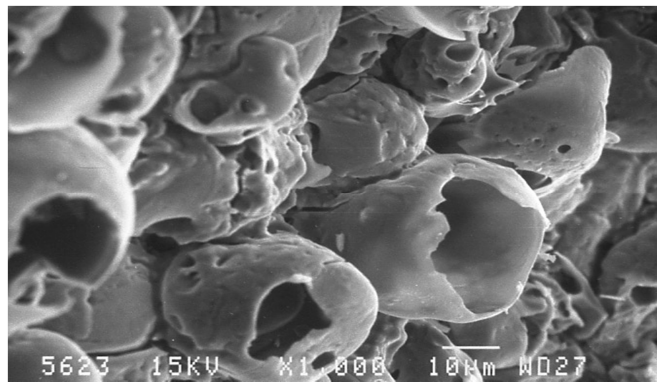

6

Рис. 2.4. Типичная морфология поверхности кальций-фосфатного покрытия, полученного методом дугового оксидирования, увеличение: а ×1000, б ×10000 (Агаджанян и др., 2011).

Покрытия формируется рентгеноаморфными фазами с незначительным содержанием кристаллических наноструктурных форм. Температурный диапазон кристаллизации 
покрытия лежит в пределах $720-780^{\circ} \mathrm{C}$. Химический состав покрытий представлен различными формами титано-фосфатов кальция $\mathrm{CaTi}_{4}\left(\mathrm{PO}_{4}\right)_{6}, \mathrm{CaTiO}_{3}$ с включением фосфатов кальция $\mathrm{CaP}_{2} \mathrm{O}_{6}$, что подтверждается результатами рентгенофазового анализа (РФА).

Элементы, входящие в состав покрытия, по результатам энергодисперсионного анализа: $\mathrm{Ti}=30,12 \%, \mathrm{Ca}=24,00 \%, \mathrm{P}=45,87 \%$ при соотношение $\mathrm{Ca} / \mathrm{P}=0,52$, которое меньше стехиометрического соотношения $\mathrm{Ca} / \mathrm{P}$ в ГА. Низкое соотношение $\mathrm{Ca} / \mathrm{P}$ связано, в первую очередь, с механизмом формирования дугового КФ покрытия, которое образуется на титановом электроде посредством окисления Ті и включения его окислов в структуру покрытия. Адгезионная прочность покрытий к титановой подложке порядка 20-30 МПа. Высокая биосовместимость КФ покрытий, полученных микродуговым оксидированием на титановых сплавах, подтверждена во многих работах, результаты исследований приведены, например, в обзорах (Карлов, Шахов, 2001; Петровская и др., 2011).

Недостатком КФ покрытий, полученных методом МДО, является низкая эластичность и высокая хрупкость. К тому же метод МДО имеет ограничение, т.к. позволяет наносить покрытия только на материалы вентильной группы. С другой стороны, в качестве металлической остовы некоторых имплантатов предпочтительнее использовать нержавеющую сталь и ее сплавы, т. к. Ti, $\mathrm{Nb}, \mathrm{Zr}$ уступают им по своим прочностным характеристикам. Решить эту проблему можно путем создания композитной структуры, в которой сталь играет роль прочной основы, на неё наносится слой-праймер материала вентильной группы, например, титан с последующим микродуговым оксидированием в электролите, содержащем соединения кальция и фосфора. В процессе МДО происходит перемешивание оксидируемого материала с ионами кальция и фосфора, поступающими из электролита. В результате на материале происходит образование КФ композита (Твердохлебов и др., 2012).

Наиболее распространенными методами нанесения титановых покрытий являются: плазменное напыление в различных средах, конденсация материала из плазмы вакуумнодугового и/или магнетронного разрядов. Сформированные Ті пленки для реализации предложенной гибридной технологии должны иметь достаточную толщину и обладать высокой адгезией с материалом основы, для чего их предпочтительно наносить вакуумными ионно-плазменными методами. Для нанесения титанового слоя была применена комплексная установка (КУ) (Ryabchikov, Stepanov, 2009), которая реализует технологии ионно-лучевой и ионно-плазменной модификации материалов, позволяет осуществлять очистку, активацию поверхности, ионную имплантацию и формирование 
широких переходных слоев между основой и покрытием, а также осаждение покрытий в условиях интенсивного ионного перемешивания.

Толщина титановых покрытий варьировала в пределах 5-40 мкм. На рис. 2.5 представлены полученные с помощью растрового электронного микроскопа (РЭМ) изображения образцов с титановым покрытием. Их анализ показывает, что на поверхности титанового покрытия имеются отдельные кристаллиты титана и кратеры различных размеров. При МДО стальных подложек с титановым слоем-праймером толщина формируемых аморфных КФ покрытий составляет порядка 7-15 мкм, пористость - 2-8 \%, размер пор - 5-7 мкм, их поверхность имеет типичную для МДО структур (рис. 2.6), они не ухудшают прочностные свойства материала основы, имеющего слой-праймер.

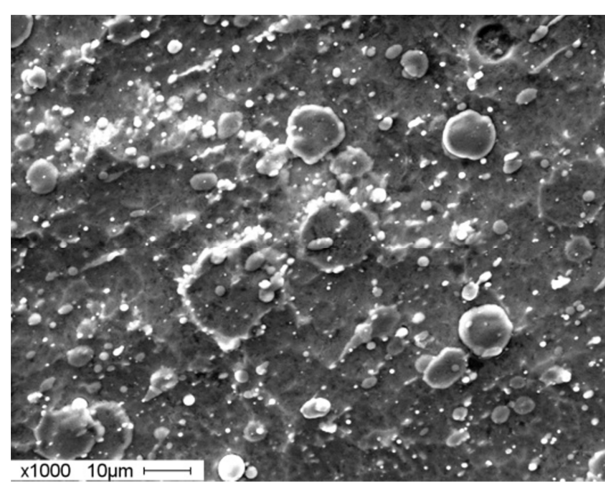

a

Рис. 2.5. Морфология титанового покрытия, увеличение: а $\times 1000 ; \quad 6 \quad \times 2500$ (Твердохлебов и др, 2012).

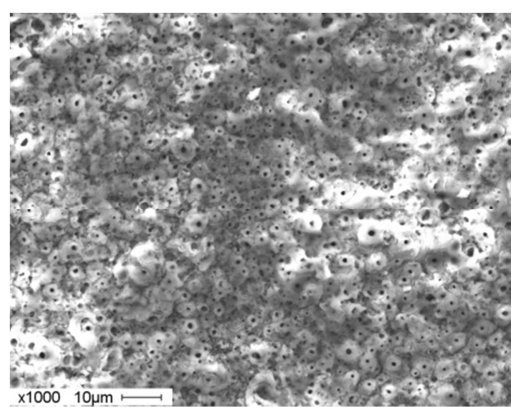

a

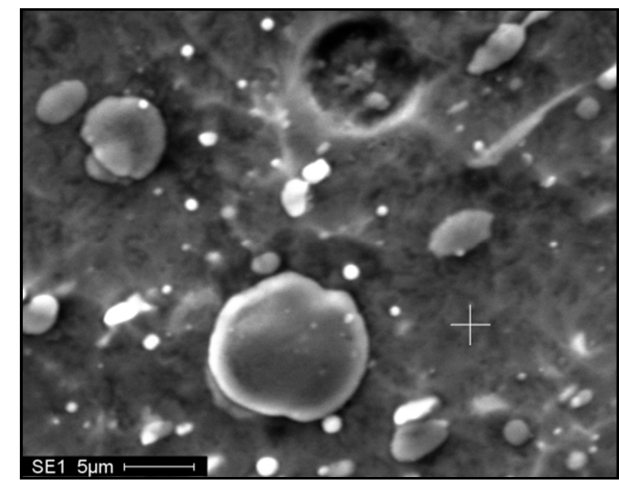

6

Рис. 2.6. Морфология поверхности кальций-фосфатного покрытия, сформированного МДО методом на стальной подложке с титановым слоем-праймером, увеличение: а ×1000, 6 ×8000 (Твердохлебов и др, 2012).

Кристаллизация аморфного КФ покрытия происходит в температурном диапазоне 720-780 ㄷ. Свойства кристаллизованного покрытия: шероховатость $\left(R_{\mathrm{a}}-2,38\right.$ мкм, $R_{\mathrm{z}}-$ 
14,15 мкм), микротвердость $-7,17 \pm 2,66$ ГПа $\left(F_{\max }=300 \mathrm{mH}\right)$ и модуль упругости $\mathrm{E}=160 \pm 43$ ГПа. Состав покрытия сформирован рентгеноаморфными фазами с незначительным содержанием кристаллических наноструктурных форм. На поверхности покрытия появляются сферолиты размерами до 10 мкм с отверстиями до 2 мкм. Содержание кальция интегрально повышается до $23 \%$. По данным энергодисперсионного анализа, в состав покрытия входят 47,88 ат. \% титана, 9,16 ат. \% кальция, 12,39 ат. \% фосфора, соотношение $\mathrm{Ca} / \mathrm{P}=0,74$.

Поперечная структура биокомпозита по результатам РЭМ показана на рис. 2.7,

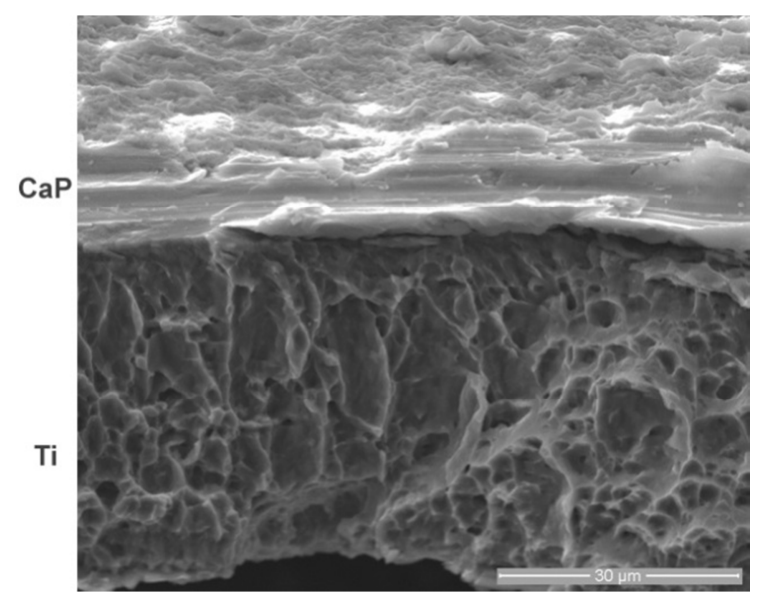

Рис. 2.7. Поперечная структура биокомпозита титановый слой-праймер (Тi) - кальций-фосфатное (CaP) покрытие (Твердохлебов и др, 2012).

Таблица 2.1. Химический состав многослойной системы «стальная подложка биокомпозит» по результатам энергодисперсионного анализа, ат. \%

\begin{tabular}{|c|c|c|c|c|c|c|c|}
\hline Анализируемая область & \multicolumn{7}{|c|}{ Химические элементы } \\
\cline { 2 - 9 } многослойной системы & $\mathrm{O}$ & $\mathrm{P}$ & $\mathrm{Ca}$ & $\mathrm{Ti}$ & $\mathrm{Fe}$ & $\mathrm{Cr}$ & $\mathrm{Ni}$ \\
\hline Поверхность биокомпозита & 24,97 & 18,13 & 20,58 & 36,33 & - & - & - \\
\hline $1 / 2$ толщины биокомпозита & 6,17 & 11,23 & 10,18 & 72,42 & - & - & - \\
\hline $\begin{array}{c}\text { Переходный слой «сталь - } \\
\text { биокомпозит» }\end{array}$ & 1,22 & 0,91 & 0,51 & 2,46 & 70,27 & 5,88 & 18,75 \\
\hline Стальная подложка & - & - & - & - & 80,34 & 12,7 & 6,97 \\
\hline
\end{tabular}

Как видно из рисунка 2.7 титановый слой имеет пористую структуру, КФ покрытие более плотное, их граница не имеет видимых дефектов и отслоений. Данные таблицы 2.1 демонстрируют, что в переходном слое «сталь - биокомпозит» присутствуют химические элементы материала подложки (железо, хром, никель) и титанового слоя-праймера при небольшом количестве элементов КФ соединений. На глубине, равной половине толщины биокомпозита, отсутствуют железо, хром, никель, основным элементом является титан, 
что свидетельствует о полной изоляции подложки слоем-праймером. Количество элементов КФ соединений увеличивается ближе к поверхности биокомпозита.

Разработанный гибридный метод нанесения многослойных покрытий, основанный на технологиях нанесения титанового слоя-праймера и его последующего микродугового оксидирования, можно использовать и для формирования КФ покрытий на керамических имплантатах.

\subsection{2. Гибридный метод формирования многослойных покрытий на основе PVD технологий}

В ряде случаев требуются имплантаты с тонкими КФ покрытиями, которые не разрушаются в ходе операции и улучшают прочность сцепления имплантата с костной тканью за счет остеоинтеграционных свойств. Перспективным методом формирования беспористых, высокоадгезивных, остеоинтеграционных КФ покрытий является высокочастотное (ВЧ) магнетронное напыление [Аронов и др., , 2007], которое относится к вакуумным технологиям «физического осаждения из паровой фазы»-physical vapor deposition (PVD). Процесс осаждения покрытий при PVD процессах протекает, как правило, в несколько стадий:

1. подготовка осаждаемого материала:

a) переход от материала в конденсированном состоянии (в твёрдой или жидкой фазе) к материалу в паровой фазе,

б) в случае осаждения соединения проведение реакции между компонентами, некоторые из которых могут быть введены в камеру в виде газа или паров;

2. перенос паров между источником и подложкой;

3. конденсация паров (и газов) на подложке, приводящая к зарождению и росту плёнки.

Высокочастотное магнетронное распыление (ВЧМР) различных материалов, так называемых мишеней, широко используется в микроэлектронике для нанесения пленок сложных оксидов без изменения их стехиометрического состава. Метод основан на распылении материала за счет бомбардировки поверхности мишени ионами рабочего газа (в основном аргона), образующимися в плазме аномального тлеющего разряда при наложении на него магнитного поля. При подаче ВЧ напряжения между мишенью (катодом) и анодом возникает электрическое поле и возбуждается тлеющий разряд. Наличие замкнутого магнитного поля у распыляемой мишени позволяет локализовать плазму разряда непосредственно у её поверхности. Электроны, эмитированные с катода под действием ионной бомбардировки, захватываются магнитным полем и циркулируют по замкнутым траекториям (циклоида) у поверхности мишени. Такая циркуляция 
происходит до тех пор, пока не произойдет несколько ионизирующих столкновений с атомами рабочего газа, в результате которых они теряют энергию, полученную от электрического поля. Таким образом, большая часть энергии электронов используется на ионизацию и возбуждение, что значительно увеличивает эффективность процесса ионизации и приводит к возрастанию концентрации положительных ионов у поверхности мишени. Это, в свою очередь, приводит к увеличению интенсивности ионной бомбардировки мишени атомами рабочего газа и значительному росту скорости осаждения покрытия [(Rossnagel, 1995].

При ВЧ магнетронном напылении КФ пленок распыляемая мишень изготавливается, как правило, путем спекания порошков кальций-фосфатных соединений, например, гидроксиапатита (ГА), реже - их плазменным напылением на катод [Yoshinari et al., 1997]. Чаще всего распыление ГА мишеней осуществляют при давлениях рабочего газа, обычно аргона, 0,1 - 5,0 Па, удельной мощности ВЧ разряда от 1 до 100 Вт/см². При этих условиях скорости осаждения покрытий составляют 1 - 200 нм/мин. Большинство авторов сообщают об аморфной структуре пленок, полученных на неподогреваемых перед напылением подложках. Образование кристаллических фаз при осаждении покрытий на подогреваемые Si подложки наблюдали Nelca с соавт. ( 2003): при температуре подложек $550{ }^{0} \mathrm{C}$ в пленках формировались фазы ГА и СаO. Независимо от условий распыления в большинстве работ отмечается завышенное соотношение $\mathrm{Ca} / \mathrm{P}$ в пленках по сравнению с мишенями. Завышенное $\mathrm{Ca} / \mathrm{P}$ связывают с потерями группы $\mathrm{PO}_{\mathrm{x}}$, как в результате обеднения мишени более легкими по сравнению с Са атомами Р, так и в результате перераспыления осажденных пленок [Van Dijk et al., 1995]. Оценка влияния давления Ar на соотношение $\mathrm{Ca} / \mathrm{P}$ в пленках проведена в [Ozeki et al., 2002; Boyd et al., 2007]. Общая закономерность - снижение соотношения $\mathrm{Ca} / \mathrm{P}$ при повышении давления $\mathrm{Ar}$. Свежеосажденные пленки обладают, как правило, высокой твердостью и адгезией. ВЧМР позволяет создавать тонкие, равномерные, плотные кальций-фосфатные покрытия, однородные по структуре и составу [Van der Wal et al., 2006; Yonggang et al., 2007; Pichugin et al., 2008, Твердохлебов и др., 2012].

Типичная морфология поверхности КФ покрытий, сформированных методом ВЧМР на медицинских изделиях представлена на рис. 2.8. Микроскопические исследования показывают, что покрытия, полученные методом ВЧМР, являются сплошными, повторяют исходную морфологию поверхности имплантата, не имеют собственной макро и микропористой структуры, что объясняется механизмом их атомарного роста. 


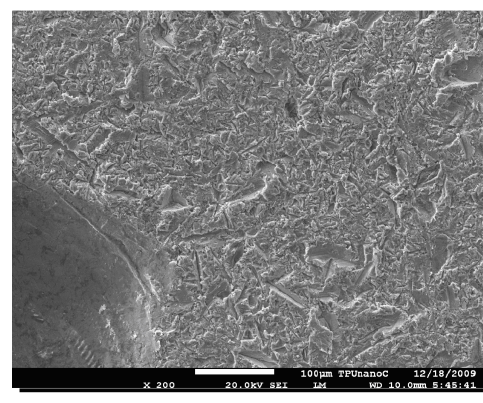

a

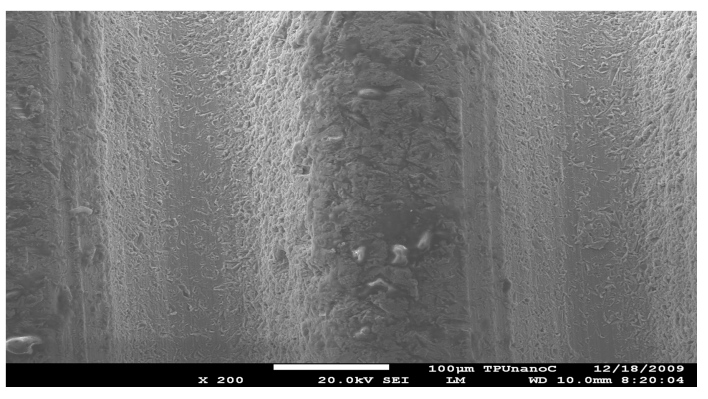

б

Рис. 2.8. Морфология поверхности покрытия, сформированного методом ВЧМР, а - минипластина ×200, б - микровинт ×200 (Твердохлебов и др., 2012).

По результатам оже-спектрометрии основными элементами покрытия являются кальций, фосфор и кислород, входящие в состав распыляемой ГА мишени. Отмечается высокое содержание Са и Р, которые составляют примерно $60 \%$ атомной массы всего покрытия, и перемешивание КФ покрытия с материалом подложки, что обеспечивает хорошие адгезионные свойства [Аронов и др., 2007].

Отмечено, что напыленные методом ВЧМР КФ покрытия аморфны, т. е. они более растворимы in vitro и более деградируемы in vivo [Weng et al., 1997]. Скорость растворения КФ покрытий in vitro определяется степенью кристалличности покрытия [Cooley et al., 1992; Wolke et al., 1994). Поэтому в некоторых случаях требуется термическая обработка покрытия, в результате которой происходит его кристаллизация (Yang et al., 2005], но вследствие различий в коэффициенте температурного расширения КФ покрытия и металлической подложки обычная термообработка в электрической печи может привести к появлению трещин в покрытии и ослаблению прочности связи [Van Dijk et al., 1996]. Поэтому применяют быстрый нагрев аморфных КФ покрытий инфракрасным излучением, который вызывает фазовые изменения в пленках при более низкой температуре, чем при отжиге в электропечи [Yoshinari et al., 1997].

У большинства имплантируемых металлических материалов наблюдается выход электронов в раствор, что приводит к их высокой коррозии в биологических средах. Коррозия является нежелательной химической реакцией, которая может приводить к разложению металлических имплантатов на оксиды, гидроксиды и другие соединения. Эти продукты деградации могут вызывать местный воспалительный отклик, приводящий к прекращению образования кости, синовииту и расшатыванию имплантата [Patterson et al., 2005]. Поэтому после растворения КФ покрытия, предназначенного стимулировать запуск процессов репаративной регенерации костной ткани, металлический имплантат должен оставаться защищенным от коррозии, что можно обеспечить путем осаждения на его поверхность химически инертного диэлектрического покрытия. 
Существует несколько технологических методов термического оксидирования металлов и сплавов:

- оксидирование в воздушной атмосфере [Жук, 1968; Родионов и др., 2007, 2007; Войтович, Головко, 1984];

- паротермическое оксидирование[(Гладкова, 1973; Родионов, Бутовский, 2007];

- оксидирование в газовых средах [Родионов и др., Патент РФ № 2322267, 2008].

Было предложено металлические имплантаты термически оксидировать в атмосфере чистого кислорода с предварительным вакууммированием рабочего объема камеры, что позволяет формировать на их поверхности высококачественное оксидное покрытие с различной толщиной, которая регулируется минимальным количеством технологических параметров: температурой процесса и временем выдержки [Шестериков, 2012].

Приемлемая защита металлических имплантатов от коррозии обеспечивается при наличии оксидной пленки, толщиной не менее 0,05 мкм. Экспериментальные результаты показывают, что при оксидировании при температуре от $500{ }^{0} \mathrm{C}$ до $600{ }^{0} \mathrm{C}$ в течение $30 \div 60$ минут на всех типах металлических имплантатов образуется сплошное оксидное покрытие без макроскопических дефектов и трещин, что обеспечивает изоляцию металла от окружающей среды.

В свою очередь, гибридная технология, предполагающая формирование многослойного покрытия, состоящего из оксидного слоя и КФ покрытия, позволяет обеспечить выполнение медико-технических требований, предъявляемых к покрытиям на имплантатах для травматологии. Предложенные многослойные (гибридные) покрытия позволяют повысить эффективность реконструктивной хирургии за счет:

1) увеличения коррозионной стойкости и уменьшения выхода из имплантатов в окружающие ткани легирующих добавок, вредных для организма;

2) механических характеристик, согласованных с костным окружением;

3) благоприятного микроокружения для клеток и тканей организма;

4) возникновения возможности регуляции клеточного цикла посредством использования физико-химических свойств поверхности имплантата;

5) создания возможности для активации регенераторного потенциала эндогенных стволовых клеток организма посредством гуморальных факторов и цитокинов, выделяемых при взаимодействии биологических тканей с имплантатами.

В Томском политехническом университете создана установка для формирования гибридных покрытий, общий вид которой приведен на рис. 2.9 и определены оптимальные режимы формирования гибридных покрытий. 


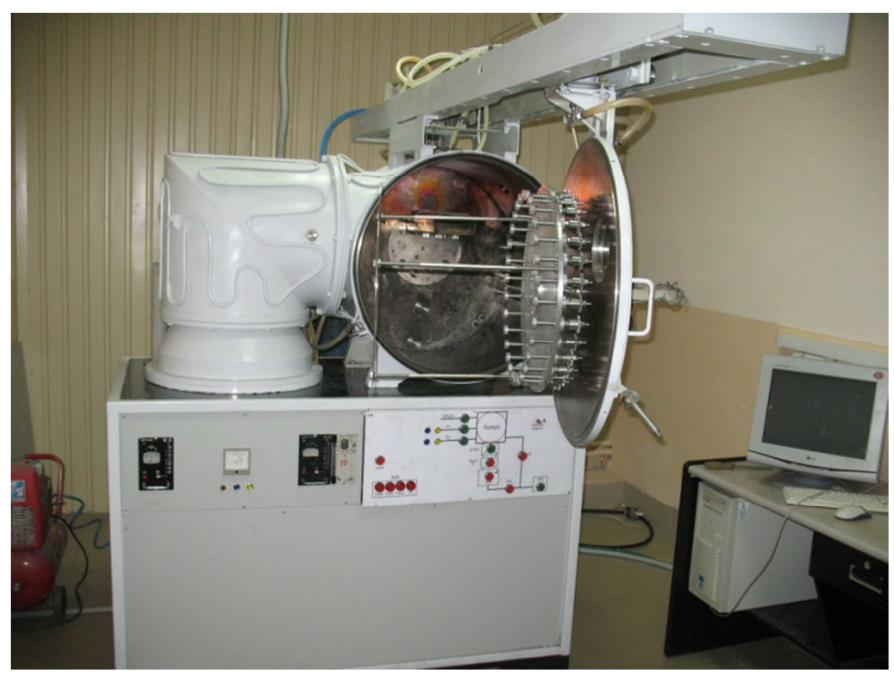

a

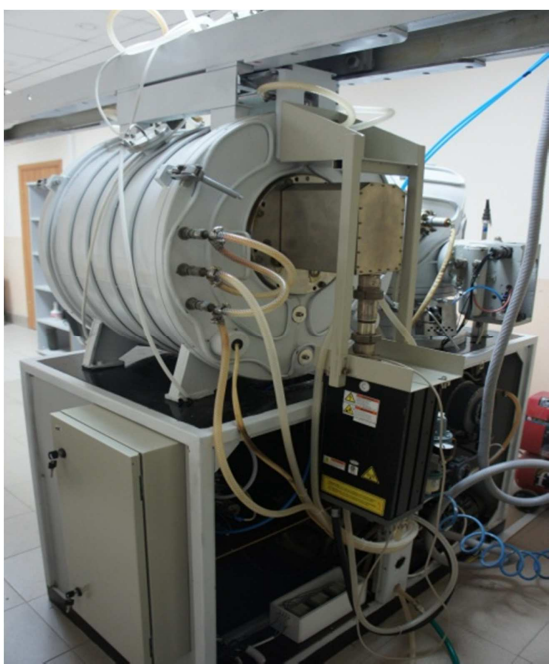

6

Рис.2.9. Установка для формирования гибридных покрытий: а - вид спереди, б - вид сзади.

Таблица 2.2. Режимы напыления КФ покрытий.

\begin{tabular}{|c|c|c|c|}
\hline Рабочий газ & \begin{tabular}{l|} 
Рабочее \\
давление, \\
Па
\end{tabular} & $\begin{array}{l}\text { Средняя } \\
\text { скорость роста, } \\
\text { мкм/час }\end{array}$ & Общие параметры \\
\hline $\mathrm{Ar}$ & 0.3 & 0,37 & \multirow{3}{*}{$\begin{array}{l}\text { - частота генератора } 13,56 \text { МГц; } \\
\text { - предварительное давление в камере } 5 \times 10^{-5} \\
\text { Па (безмасляная откачка); } \\
\text { - удельная ВЧ мощность на мишени } 20 \\
\text { Вт/см²; } \\
\text { - без предварительного нагрева образцов и } \\
\text { изделий. }\end{array}$} \\
\hline $\mathrm{Ar}+\mathrm{O}_{2}$ & $0,3^{*}$ & 0,30 & \\
\hline $\mathrm{O}_{2}$ & 0,3 & 0,26 & \\
\hline
\end{tabular}

* газовая смесь аргона с кислородом в пропорции 1:1 при суммарном давлении 0,3 Па, далее в тексте данный режим будет обозначаться $\left(\mathrm{Ar}+\mathrm{O}_{2}\right)$.

Термический оксидный слой толщиной 0,15 мкм, сформированный на поверхности нержавеющей стали, не меняет исходную шероховатость стальных подложек. При гибридной технологии последующий КФ слой, нанесенный на оксид, повторяет морфологию исходной подложки, увеличивая её микрошероховатость.

Исследований элементного, химического и фазового состава КФ покрытий, сформированных ВЧ магнетронным напылением в одних и тех же режимах напыления, но различных газовых атмосферах, показывают, что их фазовом и химическом составах, близких к следующим соединениям: в атмосфере $\mathrm{Ar}$ - аморфного фосфата кальция (АФК) $\mathrm{Ca}_{\mathrm{x}}\left(\mathrm{PO}_{4}\right)_{\mathrm{y}} \mathrm{zH}_{2} \mathrm{O}(\mathrm{Ca} / \mathrm{P} \approx 2,78 \pm 0,72) ;$ в атмосфере смеси газов $\left(\mathrm{Ar}+\mathrm{O}_{2}\right)$ - гидроксиапатита $\mathrm{Ca}_{10}\left(\mathrm{PO}_{4}\right)_{6}(\mathrm{OH})_{2} \quad(\mathrm{Ca} / \mathrm{P} \approx 1,72 \pm 0,09) ; \quad$ в атмосфере $\mathrm{O}_{2}$-нестехиометрического гидроксиапатита $\mathrm{Ca}_{10-\mathrm{x}}\left(\mathrm{HPO}_{4}\right)_{\mathrm{x}}\left(\mathrm{PO}_{4}\right)_{6-\mathrm{x}}(\mathrm{OH})_{2-\mathrm{x}}(0<\mathrm{x}<1)(\mathrm{Ca} / \mathrm{P} \approx 1,48 \pm 0,05)$. Соответственно, для формирования КФ пленок, близких по химическому, фазовому составу и стехиометрическом соотношению $\mathrm{Ca} / \mathrm{P}$, близкому к гидроксиапатиту, необходимо использовать при ВЧМР в качестве рабочего газа смесь аргона с кислородом. 
Механические характеристики КФ покрытий не зависят от материала подложки, твердость и модуль Юнга совпадают в пределах погрешности измерений, но зависят от режимов напыления; КФ покрытия, сформированные в атмосфере $\mathrm{Ar}$, обладают твердостью и модулем Юнга, значения которых в среднем выше на $20 \div 25 \%$, чем у покрытий, сформированных в $\mathrm{O}_{2}$ и в смеси $\mathrm{Ar}+\mathrm{O}_{2}$. Низкий модуль упругости покрытий приводит к уменьшению механических напряжений между покрытием и имплантатом, что способствует сохранению целостности покрытия при функциональных нагрузках. Совокупность высокой твердости и упругого восстановления (эластичности) КФ покрытий дает им возможность выдерживать значительное механическое воздействие в ходе медицинской технологии.

Наибольшей адгезионной прочностью обладают КФ покрытия, сформированные на поверхности оксидированной нержавеющей стали в смеси газов $\mathrm{Ar}+\mathrm{O}_{2}$.

КФ покрытия, сформированные на оксидированной нержавеющей в смеси газов $\mathrm{Ar}+\mathrm{O}_{2}$, имеют наименьший угол смачивания водой $39 \pm 3$ градуса и наибольшее значение свободной энергии поверхности $74 \pm 3$ мДж/м², что в 2 раза превышает исходную энергию для поверхности нержавеющей стали с оксидным слоем. Последнее связано с увеличением количества полярных групп, электрических зарядов и свободных радикалов, возникающих на поверхности при ВЧ напылении КФ покрытия в атмосфере двух рабочих газов, за счет образования большого количества разорванных химических связей.

Для возникновения регенеративной реакции потенциал, создаваемый на поверхности клетки внешним электрическим полем, должен быть сравним по величине с биологически действующими значениями потенциала на плазматической мембране клетки (Сидоренко, 2001). Было показано, что рост костной ткани наблюдается в области отрицательного заряда, в то время как у анода, отмечается остеонекроз [Смирнов, 2000; Соловьёв и др., 2002; Albrektsson, Johansson, 2001; Wang et al., 2002]. Остеобласты мигрируют к отрицательному, а остеокласты - к положительному электроду [Ferrier et al., 1986]. Поэтому для снижения микробной обсемененности и предупреждения развития воспалительных осложнений вокруг имплантата необходимо, чтобы поверхность имплантата обладала некомпенсированным отрицательным электрическим потенциалом, создающим условия для нормализации ионно-электролитного состава в биотканях, окружающих имплантат [Ивашкевич, 2007]. По этой причине определение электрического потенциала покрытий имплантатов должны входить в состав плана исследований материалов и изделий, предназначенных для репаративной регенерации костной ткани.

Проведенные исследования показали, что после оксидирования и напыления КФ покрытия в атмосфере кислорода и $\mathrm{Ar}+\mathrm{O}_{2}$ поверхность нержавеющей стали $12 \mathrm{X} 18 \mathrm{H} 10 \mathrm{~T}$, 
исходно заряженная положительно, приобретает отрицательный заряд. Следовательно, поверхность имплантатов из нержавеющей стали с гибридным покрытием будет притягивать ионы $\mathrm{Ca}^{2+}$, находящиеся в организме, что способствует сначала образованию промежуточных кальцийсодержащих фаз, а затем слоя гидроксиапатита, устойчивого в средах организма. В случае использования рабочего газа $\mathrm{Ar}$ поверхность сформированного покрытия всегда имеет положительный потенциал независимо от типа подложки [Klimenov et al., 2011], что связано с большим содержанием в покрытии ионов $\mathrm{Ca}^{2+}$.

По отдельности оксидное и КФ покрытия обладают защитными свойствами и способны снижать скорость коррозии имплантатов в биологической среде организма. Наилучшую защиту от коррозии обеспечивает гибридное покрытие, состоящее из оксидного подслоя и КФ покрытия. После 35 дней выдержки образцов оксидированной нержавеющей стали с КФ покрытием в изотоническом растворе целостность покрытий сохранялась (рис. 2.10).
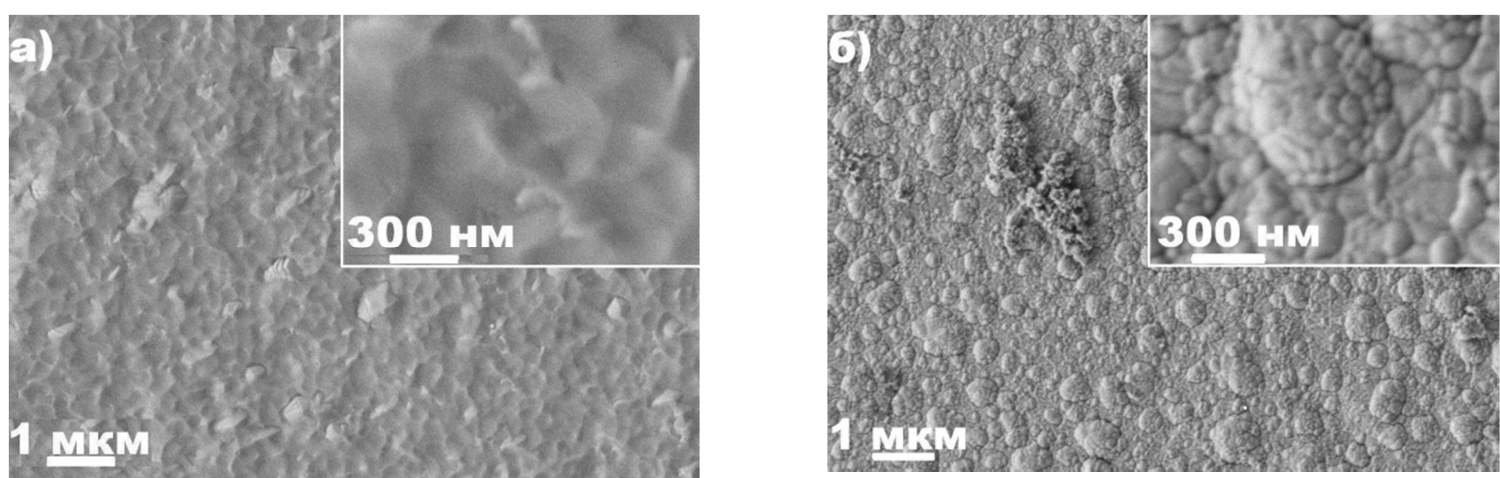

Рис. 2.10. Внешний вид КФ покрытий на оксидированной стали: а - до, б - после фиксации в течение 35 дней в растворе $0,9 \% \mathrm{NaCl}$ при $37{ }^{0} \mathrm{C}$.

Физико-химические, механические и трибологические исследования гибридных покрытий позволили определить режимы формирования покрытий, удовлетворяющих медико-техническим требованиям, разработанным совместно со специалистами РНЦ «ВТО» им. академика Г.А. Илизарова. Такое многослойное покрытие состоит из оксидного подслоя, сформированного методом газотермического оксидирования в указанных ранее режимах, и кальций-фосфатного слоя толщиной 1,6 мкм, сформированного ВЧ магнетронным напылением на частоте 13,56 МГц в смеси газов аргона и кислорода с соотношением 1:1 при давлении 0,3 Па, удельной мощности на ГА мишени $20 \mathrm{Bт} / \mathrm{cm}^{2}$.

\subsection{3. Сигнето-электрическое полимерное покрытие металлических имплантатов}


На сегодняшний день одним из основных направлений развития медицинского материаловедения является разработка гибридных технологий и поиск полимерных композитов, способных создавать трехмерную архитектонику. Идея создания композитных покрытий на основе биологически инертного полимерного связующего и биологически активного наполнителя, состоящего из фосфатов кальция или их смесей различного химического состава, принадлежит одному из патриархов современного медицинского материаловедения профессору Лондонского университета Уильяму Бонфилду [Bonfield et al., 1998]. В ходе многолетних исследований он и его коллеги пришли к выводу, что на основе сверхвысокомолекулярного полиэтилена (СВМП) и ГА возможно создание замещающих мелких конструкций. Интерес материаловедов и клиницистов к композитным материалам обусловлен возможностью получать совокупность необходимых физико-механических, химических свойств и высокую биологическую активность.

Показано, что использование полимерных композитов является перспективным, т. к. позволяет

1) регулировать механические характеристики и биологическую активности вплоть до биоинертности путём изменения массовой доли неорганического наполнителя;

2) контролировать элементный состав и скорость биологической деградации композита путём подбора соответствующих форм кальций-фосфатных соединений;

3) регулировать морфометрические характеристики композита путём регулирования дисперсности входящего в его состав наполнителя;

4) при многослойном нанесении полимерных композитов можно получать покрытия толщиной до 200-250 мкм с развитой трехмерной архитектоникой на макро- и микроуровнях, что необходимо для клеточных матриксов;

5) контролировать резорбцию материала при полном исключении возможности передачи таких инфекций, как ВИЧ, гепатит, туберкулез, сифилис и т. д.;

6) использование биодеградируемых композитов исключает необходимость повторного хирургического вмешательства для удаления имплантата.

Анализ литературных данных позволил сделать выбор материала для изготовления полимерных композитов, которые предложено делать на основе фторуглеродного пластика - сополимера тетрафторэтилена с винилиденфторидом (ТФЭ/ВДВ), наполненного мелкодисперсными фосфатами кальция различной структуры такими как: гидроксиапатит (ГА), трикальцийфосфат (ТКФ) и т.п.

В качестве подложки можно использовать не только титан, но и нержавеющую сталь в виде пластин или спиц. Для увеличения адгезии перед нанесением поверхность 
имплантата обдувают корундовым песком для придания шероховатости, затем последовательно промывают в трихлорметане $\left(\mathrm{CHCl}_{3}\right)$ и этиловом спирте $\left(\mathrm{C}_{2} \mathrm{H}_{5} \mathrm{OH}\right)$ для удаления загрязнений.

Формирование композитного покрытия осуществляли в два слоя методом пневматического распыления с использованием распылителей Minijet 4 (Sata, Germany) при следующих параметрах: диаметр сопла 1 мм, давление сжатого воздуха 1,4 атм, расстояние между распылителем и подложкой $20 \mathrm{~cm}$.

Первый слой (грунтовочный слой) покрытия формировали из $6 \%$ раствора статистического сополимера VDF-TeFE. После нанесения грунтовочного слоя образец помешали в камерную печь где нагревали до температуры $200{ }^{\circ} \mathrm{C}$ со скоростью 2 град/минуту с последующей выдержкой в течение 30 минут. Затем на прогретый до $200{ }^{\circ} \mathrm{C}$ образец наносили второй слой представлявшего собой дисперсию порошка ГА в растворе сополимера VDF-TeFE. После нанесения второго слоя осуществляли окончательное формирование композитного материала в следующих температурных режимах: нагрев до температуры $220{ }^{\circ} \mathrm{C}$ со скоростью 10 град/минуту, выдержка в течение 30 минут, остывание до температуры $100{ }^{\circ} \mathrm{C}$ со скоростью 2 град/минуту выдержка в течение 4 часов, закалка в дистиллированной воде с температурой $30{ }^{\circ} \mathrm{C}$.

Сополимер ТФЭ/ВДВ обладает уникальными физико-химических свойствами такими, как высокая химическая стойкость, биологическая инертность, низкая иммуногеноость. Фторированные полимерные материалы широко используются для изготовления имплантатов, мембран, покрытий внутрисосудистых стентов, композитных покрытий, скаффолдов для регенеративной медицины.

Другим достоинством этого материала является его технологичность, т. к. он может перерабатываться из раствора, что упрощает аппаратную реализацию процесса формирования композита.

Изображения поверхности исследуемых материалов, полученные методом SEM, при различных увеличениях представлено на рис. 2.11. При незначительных увеличениях пленка сополимера VDF-TeFE имеет однородную гладкую поверхность, обладающую низкой пористостью (Рис. 2.11a). При значительных увеличениях (Рис. 2.11б) на поверхности наблюдаются хаотически расположенные контрастные фибриллярные структуры длинной $1.1 \pm 0.3$ мкм и шириной $0.19 \pm 0.04$ мкм. Раннее образование фибрилярной структуры в неорентированных отожжённых пленках сополимеров VDFTeFE и VDF-TrFE связано с образованием кристаллических областей сегнетоэлектрической $\beta$ фазы формирующихся в пленке при высокотемпературном отжиге. 

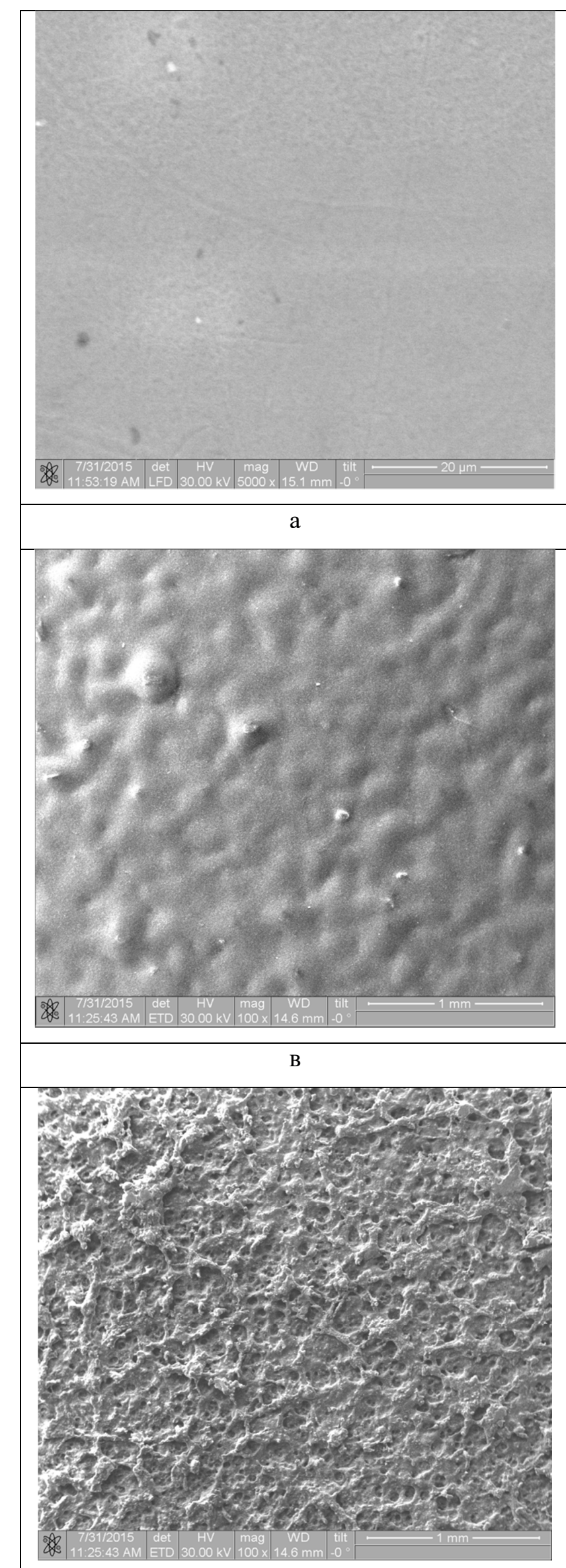

д

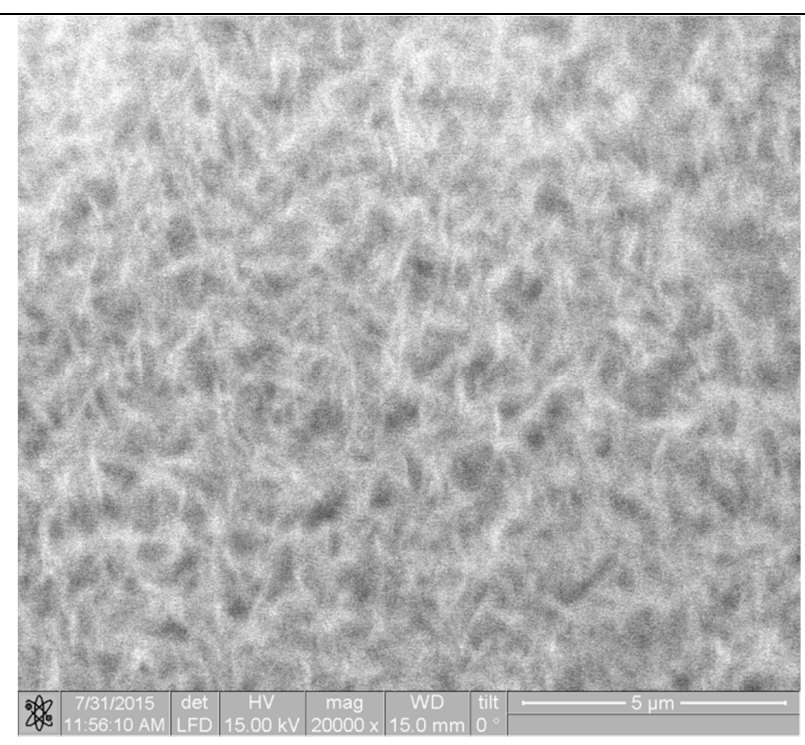

б

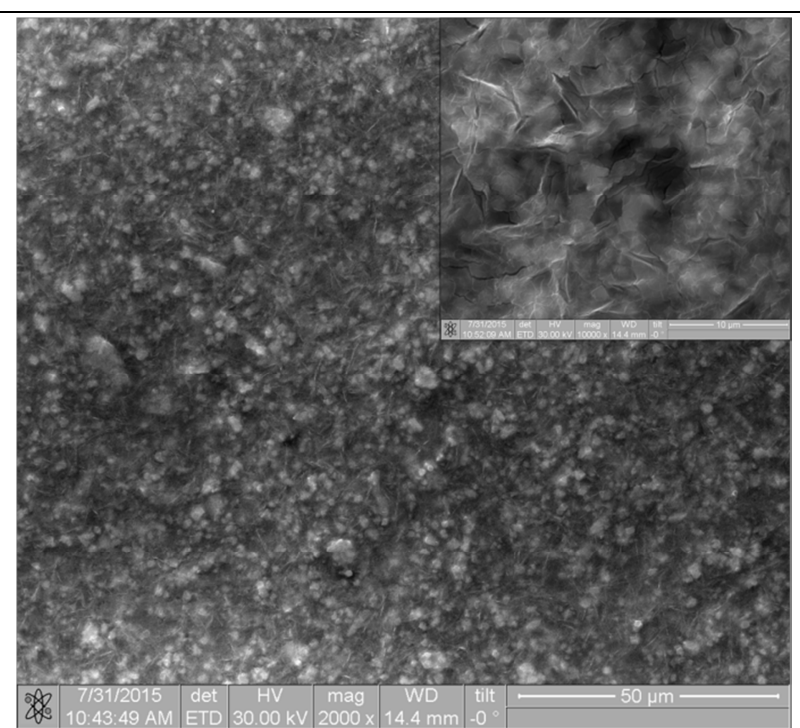

$\Gamma$

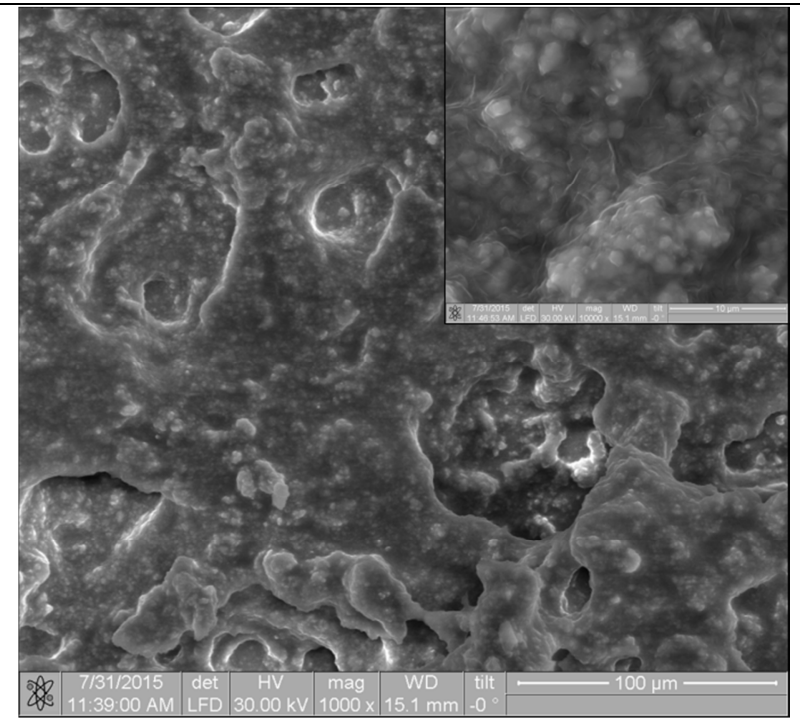

e 


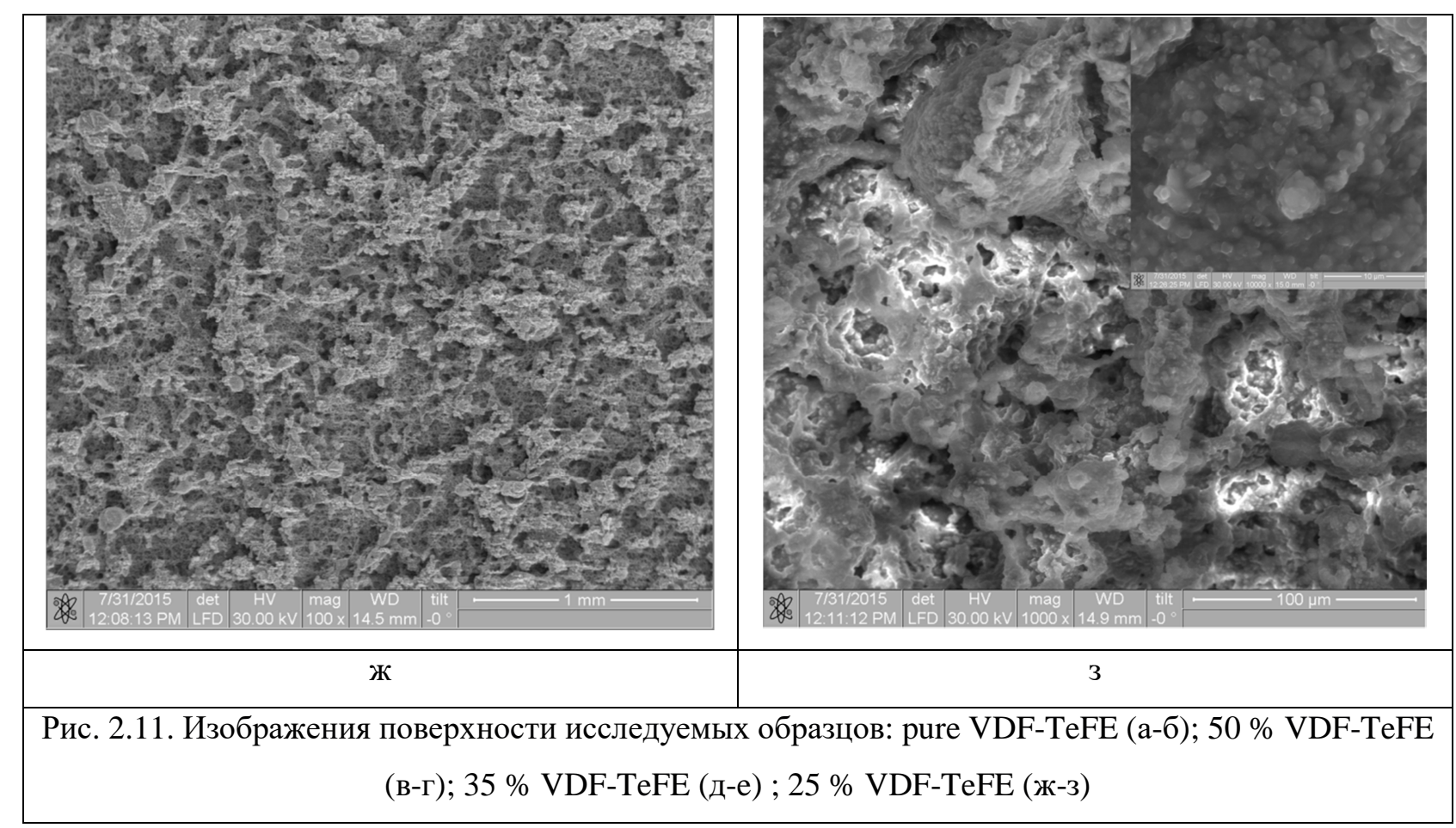

Увеличение содержания порошка гидроксиаппатита в композитном материале вызывает изменение структуры поверхности композитного материала. При содержание VDF-TeFE 50 масс \% на поверхности композитного материала формируется микрорельеф в виде “холмов” и “долин” со сглаженными округлыми краями (Рис. 2.11в). На поверхности холмов находятся частицы гидроксиаппатита вероятно покрытые тонкой пленкой сополимера VDF-TeFE имеющей многочисленные разрывы (Рис. 2.11г). Открытая пористость композитного материала составила менее 8 \% и вероятнее всего обусловлена пористостью частиц гидроксиаппатита.

Уменьшение концентрации сополимера VDF-TeFE в композитном материале до 35 \% приводит к образованию на поверхности значительного количества макропор средним диаметром $130 \pm 75$ мкм (Рис. 2.11д). На дне макропор наблюдаются микропоры средним

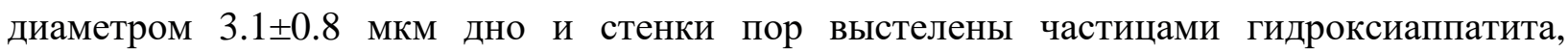
значительная часть которых выступает на поверхность композита (Рис. 2.11е). Пористость композитного материала составила $26 \pm 4 \%$.

Уменьшение концентрации сополимера VDF-TeFE до $25 \%$ увеличивает размер макропор композитного материала до $153 \pm 26$ мкм (рис. 2.11ж) микропор до 8.5 \pm 4.7 мкм

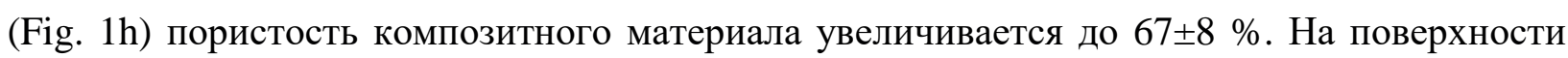
композитного материала наблюдается значительное количество частиц гидроксиапатита слабо связанных полимерным материалом (Рис. 2.113). 
Основными элементами композита с ГА наполнителем являются кальций, фосфор, кислород и фтор с небольшой примесью магния, калия, углерода и натрия ( табл. 2.3). В покрытии могут присутствовать следовые количества элементов натурального наполнителя.

Таблица 2.3. Элементный состав композитных покрытий.

\begin{tabular}{|c|c|c|c|c|c|c|c|c|}
\hline \multirow{2}{*}{$\begin{array}{c}\text { Количество } \\
\text { ГА в } \\
\begin{array}{c}\text { композите, } \\
\text { масс \% }\end{array}\end{array}$} & $\mathrm{Ca}$ & $\mathrm{P}$ & $\mathrm{O}$ & $\mathrm{F}$ & $\mathrm{Mg}$ & $\mathrm{K}$ & $\mathrm{Na}$ & $\begin{array}{c}\text { Остальн } \\
\text { Ые }\end{array}$ \\
\cline { 2 - 9 } & & & & & & & & \\
\hline 50 & 30,420 & 12,8093 & 19,9447 & 32,9557 & 0,5536 & 0,0444 & 0,4163 & 2,8554 \\
\hline 65 & 35,117 & 15,4181 & 29,1980 & 16,9024 & 0,6624 & 0,0346 & 0,5282 & 2,1392 \\
\hline 75 & 37,163 & 16,3777 & 32,6303 & 11,7968 & 0,6010 & 0,0444 & 0,5422 & 0,8441 \\
\hline
\end{tabular}

Фазовый состав минеральной части композита определяется типом биологически активного наполнителя и может задаваться от аморфного до кристаллического. От этого зависят и механические характеристики композита, который можно можно варьировать в широких диапазонах посредством изменения массового соотношения связующее/наполнитель.

Механические свойства композитных покрытий представлены в таблице 2.4. При исследовании адгезии композитных материалов мы наблюдали когезионный характер разрушения покрытия, что свидетельствует о высокой адгезионной способности исследуемых образцов. При этом наибольшими показателями прочности и относительного удлинения и эластичности обладают композитные материалы с содержанием сополимера VDF-TeFE 50 масс \%. С увеличением содержания НАР показатели когезионной прочности и относительного удлинения существенно падали, что связано с одной стороны с ростом пористости покрытия с другой с ухудшением связи между частицами HAP при уменьшение содержания сополимера VDF-TeFE.

Таблица 2.4. Механические свойства композитных покрытий.

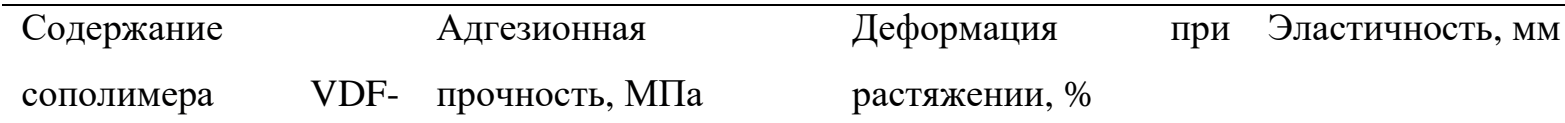

TeFE, мaсc \%

\begin{tabular}{llll}
\hline 100 & $4.2 \pm 1.8$ & $3.6 \pm 2.4$ & 1 \\
\hline 50 & $21.2 \pm 3.6$ & $35.3 \pm 5.6$ & 1 \\
\hline 35 & $15.4 \pm 1.8$ & $16.3 \pm 4.5$ & 2 \\
\hline
\end{tabular}


Особую роль во взаимодействии фторированного полимерного материала с живыми тканями играют свойства его поверхности. Важными характеристиками поверхности медицинских изделий является параметры её шероховатости, смачиваемость поверхности различными жидкостями, электрические характеристики. Неслучаен интерес к вопросу модификации поверхности фторуглеродных пластиков с целью улучшения ее биосовместимости [Klee et al., 2003]. Модификация поверхности полимера ТФЭ/ВДВ с целью придания ей биоактивных свойств проводилась путем нанесение кальцийфосфатных покрытий методом ВЧМР. Достоинством метода является и то, что процесс происходит в вакууме, способствующем экстракции остатков растворителя из объема композита и увеличению его биологической совместимости. Модификация поверхности полимера ТФЭ/ВДВ с целью придания ей биоактивных свойств проводилась путем нанесение кальций-фосфатных покрытий методом ВЧМР. Достоинством метода является и то, что процесс происходит в вакууме, способствующем экстракции остатков растворителя из объема композита и увеличению его биологической совместимости. Свойств гибридного полимерного материала ТФЭ/ВДФ с модифицированной методом ВЧМР поверхностью исследовались на нескольких группах образцов: образцы I (контрольной) группы были с полимерным покрытием без модификации поверхности, образцы II группы - время модификации поверхности 10 минут, III групп - 20 минут, IV группы - 40 минут, V группы - 60 минут [Tverdokhlebov et al., 2012].

Смачиваемость модифицированных полимерных покрытий исследовалась метод «сидячей» капли на установке «Еasy Drop». На рисунке 2.12 представлены изображения капли жидкости (верхний ряд - вода, нижний ряд - глицерин), помешенной на поверхность образцов I, II, V групп.
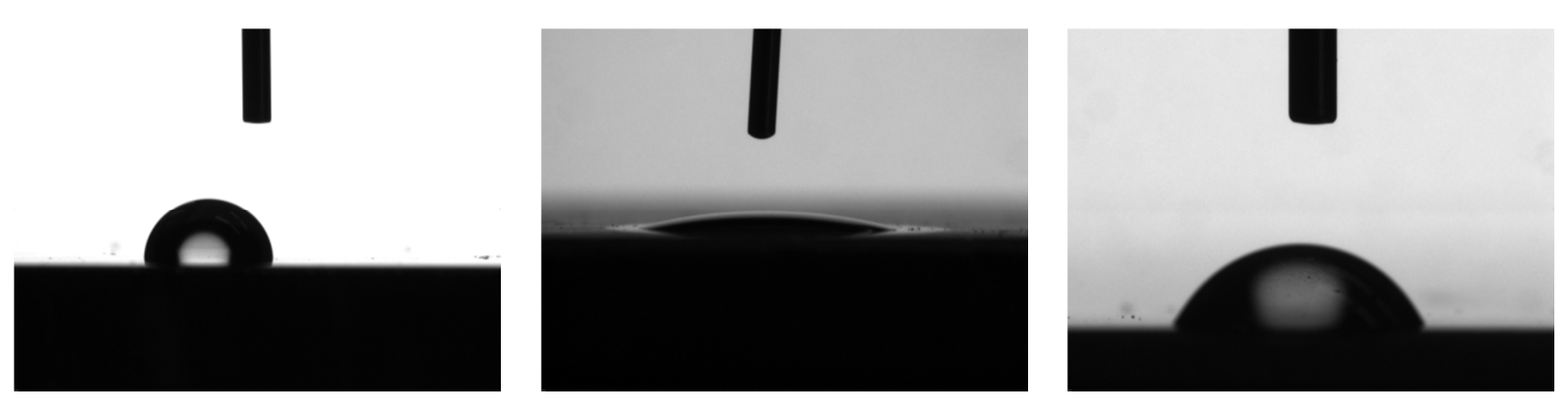


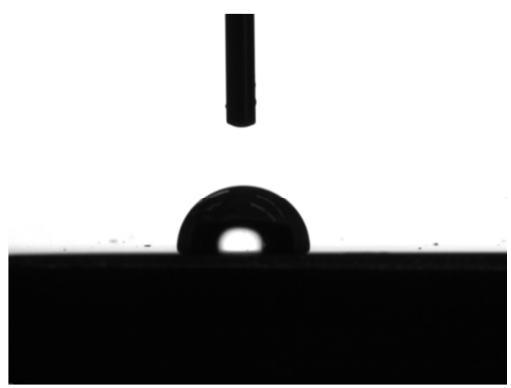

a

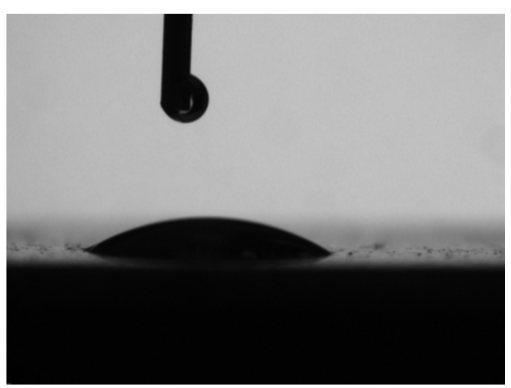

б

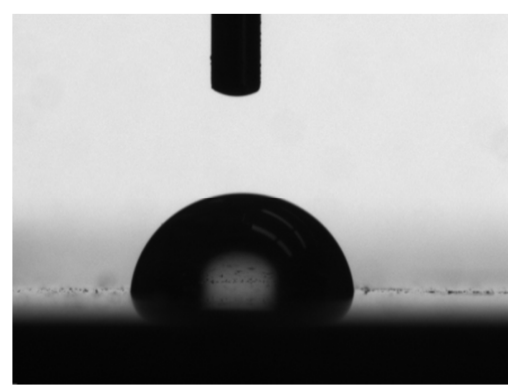

B

Рис. 2.12.. Изображения капли жидкости, помешенной на поверхность образцов, а - I группа, б - II группа, в - V группа, верхний ряд - вода, нижний ряд - глицерин (Tverdokhlebov et al., 2012).

Данные по смачиваемости исследуемых образцов, приведенные в таблице 2.5, показывают, что процесс эрозии полимера под действием плазмы аномального тлеющего разряда и одновременный с ним рост тонкой КФ пленки приводят к существенному изменению контактных свойств сополимера ТФЭ/ВДФ. Гидрофобная поверхность полимера (образцы I группы) после модификации приобретает гидрофильные свойства. При этом гидрофильность модифицированных образцов (I - V группы) изменяется нелинейно со временем модификации. Максимально гидрофильными являются образцы III группы (20 минут модификации), а минимальной гидрофильностью обладают образцы V группы (60 минут модификации).

Таблица 2.5. Углы смачивания и поверхностная энергия исследуемых образцов (Tverdokhlebov et al., 2012).

\begin{tabular}{|c|c|c|c|c|c|}
\hline $\begin{array}{c}\text { Номер } \\
\text { группы }\end{array}$ & $\begin{array}{c}\text { Краевой угол } \\
\text { смачивания } \theta \\
\text { водой, град }\end{array}$ & $\begin{array}{c}\text { Краевой угол } \\
\text { смачивания } \theta \\
\text { глицерин, } \\
\text { град } \\
\end{array}$ & $\begin{array}{c}\text { Свободная } \\
\text { энергия } \\
\text { поверхности } \\
\gamma, \text { мДж/м } \\
\end{array}$ & $\begin{array}{c}\text { Дисперсная } \\
\text { компонента } \\
\gamma^{d}, \text { мДж/м }{ }^{2}\end{array}$ & $\begin{array}{c}\text { Полярная } \\
\text { компонента } \\
\gamma^{p}, \text { мДж/м }\end{array}$ \\
\hline I & $100,7 \pm 1,2$ & $99,7 \pm 1,2$ & $12,1 \pm 1,4$ & $3,4 \pm 0,6$ & $8,7 \pm 0,87$ \\
\hline II & $19,2 \pm 1,2$ & $24,6 \pm 1,3$ & $70,2 \pm 1,7$ & $12,4 \pm 0,5$ & $57,8 \pm 1,2$ \\
\hline III & $10,2 \pm 1,1$ & $15,4 \pm 1,2$ & $72,7 \pm 1,3$ & $14,3 \pm 0,7$ & $58,4 \pm 0,6$ \\
\hline IV & $41,9 \pm 1,1$ & $42,5 \pm 1,4$ & $55,9 \pm 1,5$ & $11,9 \pm 0,6$ & $44,1 \pm 0,9$ \\
\hline $\mathrm{V}$ & $67,3 \pm 1,6$ & $85,0 \pm 1,3$ & $57 \pm 2$ & $0,45 \pm 0,19$ & $56 \pm 2$ \\
\hline
\end{tabular}

Расчет свободной поверхностной энергии, выполненный по методу OWRK (Owens, Wendt, 1969), свидетельствует о ее росте за счет роста полярной и дисперсной компонент по сравнению с контрольными образцами I группы. Рост дисперсной составляющей может быть объяснен увеличением параметров шероховатости поверхности, появлением микрорельефа и т.д. (Friedman, 2008). Рост полярной составляющей может быть объяснен 
увеличением количества полярных групп, электрических зарядов и свободных радикалов, возникающих в процессе модификации поверхности полимера плазмой аномального тлеющего разряда и ростом тонкой пленки [LeGeros, 2008].

Увеличение содержания ГА в композитном материале так же приводит к появлению на термограмме эффекта районе $116{ }^{\circ} \mathrm{C}$ и смешению эндотермического эффекта соответствующего переходу Кюри в область более низких температур что свидетельствует о нарушении кристаллической структуры сегнетоэлектрической $\beta$ фазы сополимера VDF-TeFE.

Рентгенограммы исследуемых образцов представлены на рисунке 2.13. На рентгенограмме пленки полученной из раствора сополимера VDF-TeFE наблюдается интенсивный рефлекс в области $19.4^{\circ}$ соответствующий кристаллографическим плоскостям сегнетоэлектрической $\beta$ фазы.

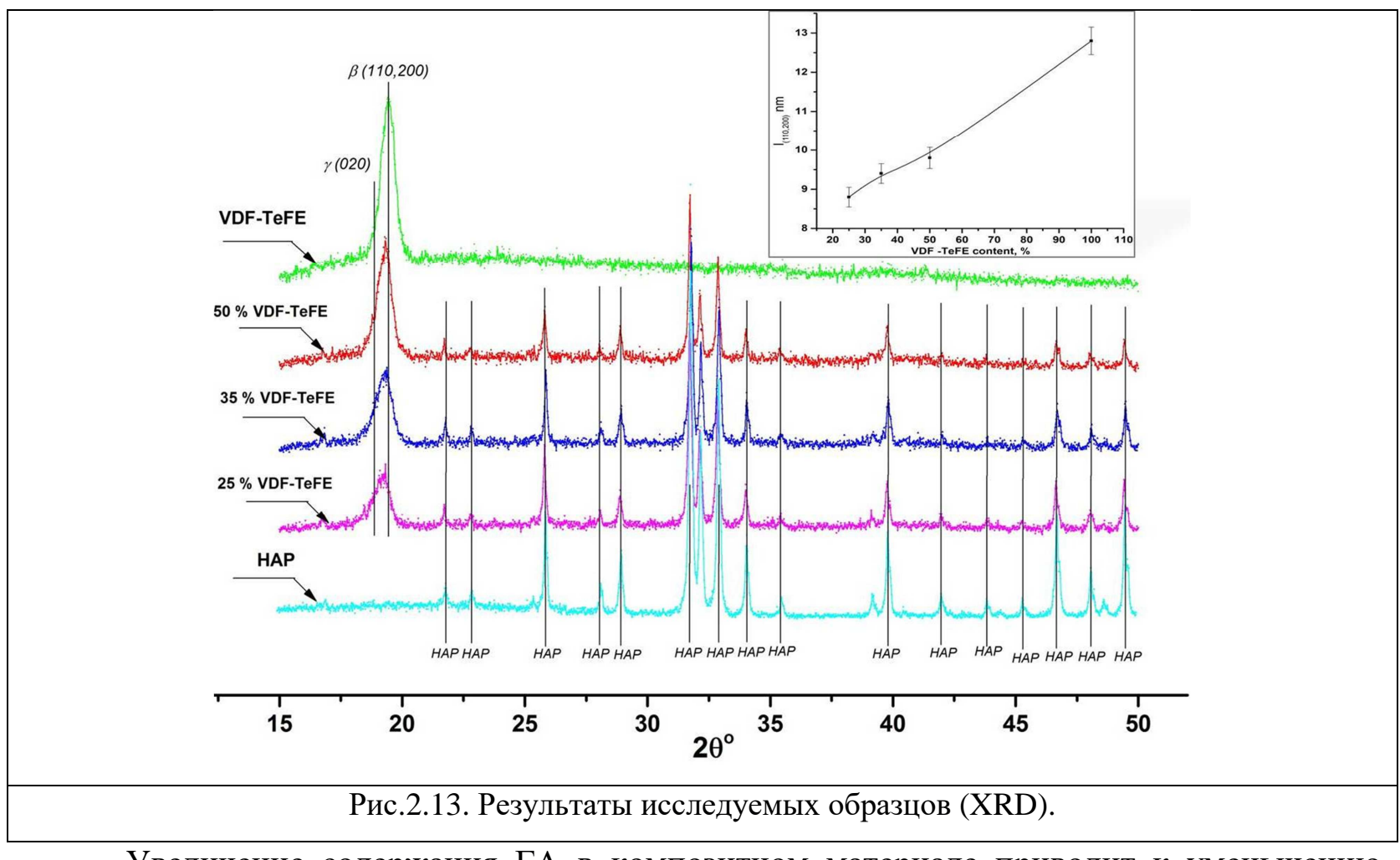

Увеличение содержания ГА в композитном материале приводит к уменьшению размеров кристалла $(l)$ сегнетоэлектрической $\beta$ фазы в плоскости $(110,200)$ (вклейка) Сдвиг рефлекса сегнетоэлектрической $\beta$ фазы в область более низких значений углов $2 \theta$ при увеличение содержания ГА свидетельствует об уменьшение плотности упаковки кристаллической решётки в направление осей $a$ и $b$.

Можно подытожить, что при создании гибридных полимерных материалов одновременное воздействие плазмы аномального тлеющего разряда и формирование 
тонкой КФ пленки на поверхности полимера приводят к изменению химического состава, параметров шероховатости, потенциала, контактных свойства поверхности. Возможность изменять свойства поверхности термопластичного полимера ТФЭ/ВДФ позволяет расширить сферу их медицинского применения. С учетом того, что полимерные покрытия на основе биосовместимых полимеров ТФЭ/ВДФ, наполненные мелкодисперсными порошками фосфатов кальция, могут иметь многоуровневую пористость, они могут насыщаться фармакологическими препаратами и персонифицированными клеточными материалами. Все это дает возможность управлять процессами репаративной регенерации костной ткани, и изделия с такими покрытиями можно назвать биочипами.

\section{3. Тенденции развития биоимплантологии}

В настоящее время проблема замещения костной ткани стоит достаточно остро. Значительная часть населения подвержена различным хроническим заболеваниям костномышечной системы, которые в той или иной степени приводят к формированию дефектов костной ткани, ее деформациям (дегенеративно-дистрофические изменения, остеопороз, воспалительные заболевания, онкологические поражения кости). Кроме того, стремительно возрастает уровень травматизма (производственного и автодорожного), который нередко приводит к инвалидизации населения за счет потери костной массы после повреждения или хирургического лечения. Значительные трудности представляет восстановление нарушенных органов или частей скелета.

В современных условиях существуют два принципиально различных подхода к решению этой проблемы: 1) простая замена поврежденного участка кости имплантатом, вплоть до создания огромной биоинженерной конструкции, замещающей кость и смежные с ней суставы, или 2) создание условий для регенерации (восстановления) кости в зоне повреждения, возможно, тоже с помощью имплантата.

Анализ современной литературы показывает, что оба направления связаны с биокерамикой, применение которой в медицине расширяется по мере углубления разработок в области химии и усовершенствования технологий производства материалов, близких по своим свойствам к костной ткани.

Перспективы использования биокерамики и определяются прежде всего возможностями изменения механических и биологических свойств имплантатов и приближением их к костной ткани. Для сравнения механических свойств искусственных материалов и кости напомним, что последняя имеет довольно сложное строение и разнообразный тканевый состав. Выдающиеся механические характеристики компактного вещества обеспечиваются особым пространственным расположением образующих его 
структурных компонентов - костных пластинок толщиной 3-10 мкм [Rivera E.M. et al., 1999; Ripamonti U. et al., 2009]. Общая масса кости на 20-25 \% определена органической составляющей (коллаген), или костным матриксом, на 60-65 \% - неорганической составляющей (фосфаты кальция), на воду приходится 9-10\%. Кроме этого, в костной ткани присутствуют в малых количествах другие органические соединения (отличные от коллагена белки, полисахариды, липиды). Коллаген придает тканям организма необходимую механическую прочность при деформациях типа растяжения и изгиба. Молекулы коллагена, состоящие из трех скрученных спирально полипептидных нитей, способны собираться в волокна диаметром 100-2000 нм. Прочность костной ткани на сжатие обусловлена минеральной составляющей - фосфатами кальция (преимущественно в форме гидроксиапатита - $\mathrm{Ca}_{10}\left(\mathrm{PO}_{4}\right)_{6}(\mathrm{OH})_{2}$. Кристаллы ГА присутствуют в кости в форме пластин (средний размер $50 \times 20 \times 5$ нм), ориентированных определенным образом по отношению к оси коллагеновых волокон.

Органический костный матрикс и неорганическая составляющая образуют своеобразный композиционный материал. Воспроизвести досконально морфологию костной ткани искусственно и, следовательно, достичь такого же, как у кости, сочетания биологических и механических свойств пока не представляется возможным, но биоматериалы, претендующие на роль имплантатов, должны удовлетворять требованиям, диктуемым структурой, составом и свойствами костной ткани:

1) химические свойства - отсутствие нежелательных химических реакций с тканями и межтканевыми жидкостями, отсутствие коррозии;

2) механические характеристики биоматериала должны быть близкими к таковым для кости - жесткость (упругость) и трещиностойкость (например, различие в упругости может привести к тому, что кость, находящаяся в контакте с имплантатом, утратит нагрузку, вследствие чего начнется ее резорбция);

3) биоактивность материала - отсутствие реакций со стороны иммунной системы, остеокондуктивность (способность к перемещению по поверхности материала микрососудов, а затем и остеогенных клеток с образованием костной ткани, в том числе и внутри сквозных пор оптимального размера) и остеоиндуктивность (способность материала к адгезии и дифференцировке мезенхимальных стволовых клеток, вплоть до остеобластов, и стимуляции их остеогенной функции), что способствует «срастанию» с костной тканью.

Из всех синтетических материалов, которые можно использовать для имплантации, наиболее перспективным является керамика на основе фосфатов кальция. Среди них гидроксиапатит не только биосовместим, но и наиболее биоактивен (особенно, если 
присутствует, как и в кости, в виде наноразмерных кристаллов). Однако основным недостатком керамики является еe хрупкость, поэтому самым рациональным в создавшейся ситуации будет применение композитов «гидроксиапатит - полимер», которые обладают близкими к кости механическими свойствами и высокой биоактивностью.

Отчетливые перспективы в этой области видны уже сегодня при замещении небольших костных дефектов, когда на первое место выходят биологические свойства материалов, прежде всего остеоиндуктивность. Сам факт разработки материалов, стимулирующих остеогенез, означает, что после почти полувекового активного применения биоматериалов приходит понимание исключительной сложности задачи восстановления и замены костной ткани. Предложенные в настоящее время композиты обладают достаточной механической прочностью для заполнения небольших дефектов костной ткани.

Наилучшими при создании ортопедических устройств для опорно-двигательного аппарата, испытывающего значительные механические нагрузки, являются биоинертные металлы и сплавы с кальций-фосфатным покрытием, обеспечивающим биологическую совместимость и выраженную биологическую активность в образовании костной ткани вокруг металла. Здесь просматриваются два направления исследований:

1. Разработка эндопротезов суставов, металлическая несущая часть которых покрывается керамикой с целью остеоиндукции и образования обширной костной муфты, обеспечивающей надежный контакт металла с костной тканью на максимальной площади, чем исключается несостоятельность фиксации элементов сустава на кости на долгие годы (30 лет и более).

2. Разработка интрамедуллярных имплантатов для замещения обширных дефектов костной ткани после травмы или радикальных резекций при ортопедических или онкологических операциях. Ввиду хрупкости современной керамики ею покрывают металлическую подложку (титан, нержавеющая сталь).

Применение того или иного материала зависит как от медико-биологических характеристик костного дефекта, так и от конкретного клинического случая. Следовательно, решение указанной задачи возможно лишь при наличии целого спектра биоматериалов. Выбор из них максимально удовлетворяющего требованиям конкретного случая позволит хирургу перейти от реконструктивно-заместительного принципа лечения на более высокий уровень - к инженерии костной ткани (тканевой инженерии).

В настоящее время, тканевая инженерия является одной из наиболее молодых отраслей медицины и базируется на принципах молекулярной биологии и генной 
инженерии. Используемый в ней междисциплинарный подход направлен в первую очередь на создание новых биокомпозиционных материалов для восстановления утраченных функций отдельных тканей или органов в целом [Langer R., Vacanti J.P., 1993; Spector M., 1999]. Основные принципы такого подхода заключаются в разработке и применении при имплантации в поврежденный орган или ткань носителей из биодеградирующих материалов, которые используются в сочетании с донорскими клетками и/или биоактивными веществами. В последние годы разработаны технологии выделения ростовых факторов, таких как трансформирующий фактор-бета-3, и их аналогов - костных морфогенетических протеинов - bone morphogenic proteins (BMPs/BMP-2 и BMP-7 (OP-1)), что позволяет использовать их в клинической практике для расширения зоны и увеличения скорости костной репарации при проведении трансплантации.

Формирование костной ткани для последующего применения в клинической практике впервые продемонстрировано в 1965 г. Тогда были выделены BMPs, которые могли стимулировать дифференцировку мезенхимальных стволовых клеток в клетки-предшественники остеогенеза с последующим формированием костной ткани. Человеческая cDNA BMP-7 (OP-1) была клонирована в 1990 г. Следующим стал рекомбинантный человеческий остеогенный протеин-1 (recombinant human osteogenic protein-1 (rhOP-1)), индуцирующий in vivo формирование новой костной ткани и обладающий схожей специфической активностью с натуральным остеогенным протеином, стимулируя пролиферацию и дифференцировку остеобластов in vitro. Он способен вызывать образование костной ткани посредством стимуляции мезенхимальных стволовых клеток и их дальнейшей дифференцировки в клетки-предшественники остеогенеза. Введение rhOP1 в область дефекта кости и в место перелома привело к полному восстановлению кости через 30 месяцев.

Данный материал использован австралийскими учеными в исследованиях, проведенных на пациентах с переломами длинных трубчатых костей. В 65 \% случаях наблюдалось полное восстановление дефекта костной ткани. Интраоперационное применение клеточных технологий на основе взрослых стволовых клеток получило широкое распространение при лечении старых и многооскольчатых переломов. Основанием для такого лечения являются достоверные данные о содержании клетокпредшественников остеогенеза в костном мозге взрослого человека - 1 клетка на 23000. Эта манипуляция может проводиться непосредственно у операционного стола, что позволяет незамедлительно использовать полученные клетки. Теоретически использование взрослых клеток-предшественников остеогенеза в достаточном количестве 
в комбинации с подходящей матрицей может быть более эффективным, чем традиционная аутологичная пересадка костной ткани. Это связано с тем, что остеогенные стволовые клетки способны сразу же начать пролиферировать и покрывать костную неоматрицу без необходимости удаления «старой» матрицы, присутствующей при аутологичной пересадке костной ткани.

По-видимому, одной из основных задач тканевой инженерии в области лечения костных патологий будет создание искусственных композитов, способных в сочетании с биоактивными молекулами (костными морфогенетическими белками, факторами роста и т.д.) индуцировать остеогенез, а при восстановлении суставных поверхностей и хондрогенез (последнее направление пока не находит практического применения). При этом такие материалы должны иметь ряд необходимых свойств кости [Yannas I.V. et al., 1984; Reddi A.H., 1998]:

• выполнять и поддерживать (scaffold) объем дефекта;

- обладать остеоидуктивностью, т.е. активно побуждать остеобласты к формированию костного матрикса и мезенхимальные клетки к дифференцировке в остеогенные клетки;

- иметь хорошие показатели биосовместимости, т.е. не вызывать у рецепиента воспалительных реакций.

Совокупность этих свойств позволит таким материалам параллельно с опорной функцией обеспечивать остеоинтеграцию - врастание клеток и сосудов в структуры имплантата (остеокондуктивность) - и стимулировать образование костной ткани вокруг имплантата на значительном протяжении (остеоиндуктивность).

За последнее время медицина получила большой объем научно-практических сведений о физиологической и репаративной (восстановительной) регенерации скелетных тканей. Физиологическая регенерация связана с высоким содержанием недифференцированных клеток в тканях, а репаративная регенерация представляет собой более быстрый по времени процесс, необходимый для выживания индивидуума. При репаративной регенерации запускается воспалительный клеточный каскад, приводящий к депозиции матрикса и затем к ремоделирующим процессам, которые обусловливают восстановление поврежденных тканей во взрослом организме. В настоящее время понимание основ репаративной регенерации в «скелетных тканях» способствует развитию тканевой инженерии в ортопедии. Тканевая инженерия подразумевает использование клеток в комплексе с биологическими или артифициальными матрицами, которые направляют клетки в процессе репарации или регенерации. Несомненно, в области лечения костных патологий перед тканевой инженерией стоит реальная задача создания 
биокомпозиционных материалов, применение которых обеспечит решение многих проблем как по трансплантации клеток и стимуляции формирования кости в местах ее повреждения, так и по снижению трудовых и финансовых затрат при устранении костных повреждений у больных различного профиля.

Существующие имплантаты для накостного остеосинтеза из массивных пластин титана с биоактивным покрытием из гидроксиапатита несколько снизили число осложнений, но не решили проблемы снижения сроков сращения переломов длинных трубчатых костей [Петровская Т.С. с соавт, 2011; Попов В.П. с соавт.,2014].Причина кроется в отсутствии полноценной остеоинтеграции имплантата.

Самым рациональным в создавшейся ситуации будет создание новых композитных имплантатов для погружного остеосинтеза из биологически совместимых титановых сплавов методом аддитивной технологии с последующим нанесением биоинспирированного покрытия из гидроксиапатита, что позволит принципиально повысить эффективность лечения переломов и посттравматических осложнений в виде обширных дефектов костной ткани на основе регенеративных технологий и остеоинтеграции. Разработка математической модели формирования кости на имплантате из ультрамелкозернистых низкомодульных биологически совместимых титановых сплавов по 3D технологии обеспечит индивидуальные для каждого больного размеры и форму замещающего участок кости имплантата, исключит дегенеративные процессы в костной ткани, контактирующей с имплантатом, а градиентное по составу, структуре и морфологии кальций-фосфатное покрытие обеспечит ускорение остеоиндуктивных процессов-активации эндогенных стволовых клеток. Таким образом, новые имплантаты будут обладать близкими к кости механическими свойствами и высокой биоактивностью.

Рынок аддитивных технологий в России развивается, но происходит это очень медленно - медицинском промышленности этот процесс практически стоит на месте. Понимают это и в правительстве РФ - в 2015 г., по итогам одного из заседаний президиума Совета при Президенте России по модернизации экономики и инновационному развитию премьер-министр Дмитрий Медведев поручил Минздраву России совместно с Минпромторгом, ФАНО, РАН и другими заинтересованными федеральными органами исполнительной власти и организациями проработать вопрос о направлениях использования аддитивных технологий в сфере здравоохранения Производство имплантатов должно быть достаточно дешевым, а клиническое использование при наличии остеоиндуктивных возможностей реально гарантировать консолидацию поврежденной кости в самые короткие сроки: консолидация простого перелома длинных трубчатых костей не должна превышать 3-4-х недель, а формирование 
дистракционного регенерата при замещении дефектов и удлинении кости, время его минерализации до такого уровня, который позволит снять аппараты внешней фиксации, должно стремиться к нулю (процесс минерализации должен совпадать с процессом формирования органического матрикса). 


\section{ГЛАВА 3. \\ ИНТРАМЕДУЛЛЯРНОЕ АРМИРОВАНИЕ - МЕТОД СТИМУЛЯЦИИ РЕПАРАТИВНОГО ОСТЕОГЕНЕЗА}

Тканевая инженерия в травматологии-ортопедии появилась, как альтернатива традиционным методам лечения патологии костно-мышечной системы, для восстановления и регенерации ткани, но есть различные стратегические направления развития. В основном сущность тканевой инженерии состоит в выборе соответствующих клеток, материалов, биохимических и физических стимуляторов для восстановления, поддержания или регенерации ткани. $\mathrm{B}$ рамках этой генеральной стратегии, кажется очевидной необходимость комбинировать физические и биохимические стимулы, дающие соответствующее окружение для регенерации ткани.

\section{1. Концепция формирования костной ткани на поверхности интрамедуллярного имплантата}

Кость представляет собой высоковаскуляризованную соединительную ткань, обеспечивающую не только механическую защиту внутренних органов, но и метаболизм минеральных веществ, кроветворную функцию костного мозга, органическую составляющую для ремоделирования и самовосстановления. Уровень обменных процессов настолько высок, что обеспечивает полное восстановление целостности органа после травмы, что объясняется степенью васкуляризации [Свешников А.А., 1986].

Кость часто сравнивают с композитным материалом, образованным органическими (коллагеновые волокна, липиды, пептиды, протеины, гликопротеины, полисахариды, цитраты) и неорганическими (фосфат кальция, карбонаты, бикарбонат натрия, окись магния, фториды) соединениями. В этом матриксе живут и функционируют костные клетки, среди обширной популяции которых наиболее важными являются остеобласты, остеоциты и остеокласты, отвечающие за образование, поддержание и резорбцию кости.

Клетки, участвующие в остеогенезе, происходят от мезенхимальных (стромальных) клеток костного мозга и находятся в эндосте и периосте. Считается, что содержания клеток-предшественников в костном мозге взрослого человека (1 клетка на 23000 ) достаточно для роста и ремоделирования кости. Повреждение кости включает сложнейшие механизмы репарации костной ткани, схожие с таковыми при ее формировании на стадии эмбриогенеза, но весь процесс репаративной регенерации занимает меньше времени и вовлекает воспалительный клеточный каскад, нейрогуморальную регуляцию, мобилизует клетки-предшественники. Количество 
последних регулируется биохимическими сигнальными молекулами в процессе восстановления костных дефектов, местное клеточное микроокружение обусловливает дифференцировку остеобластов, а высокая васкуляризация костной ткани обеспечивает необходимое поступление нутриентов и кислорода, требующихся в большем количестве, чем для нормального роста и развития кости. После дифференцировки остеогенные клетки продуцируют органическую составляющую кости, которая подвергается последовательной минерализации.

В настоящее время понимание основ репаративной регенерации в «скелетных тканях» способствует развитию тканевой инженерии в ортопедии и травматологии, что обусловлено прежде всего неудовлетворенностью сроками и результатами консолидации переломов. Когда современная наука утверждает, что переломы требуют не менее 12 недель для сращения, а реальные сроки реабилитации пациента затягиваются до 10-12 месяцев, встает вопрос о развитии медицинских технологий, направленных на стимуляцию репаративного процесса.

Тканевая инженерия подразумевает использование клеток в комплексе с биологическими или артифициальными матрицами, которые направляют клетки в процессе репарации или регенерации. Эти клетки могут «управляться» при помощи специальных биоактивных молекул, ex vivo - генной трансфекцией или физическими факторами и формировать новые ткани in vitro для последующей реимплантации in vivo. Кроме того, клетки и специальные матрицы, которые включают в себя биоактивные молекулы, такие как ростовые факторы, могут комбинироваться in vivo для последующего усиления тканевой репарации. В отношении костной ткани исследователи идут прежде всего по пути копирования природы: создание композита (биокерамики), максимально схожего по химическому составу, строению и механическим свойствам губчатому веществу кости, насыщение этой матрицы (скаффолда) клетками костного мозга, различными ростовыми факторами биологического происхождения (Рис.3.1 ). 


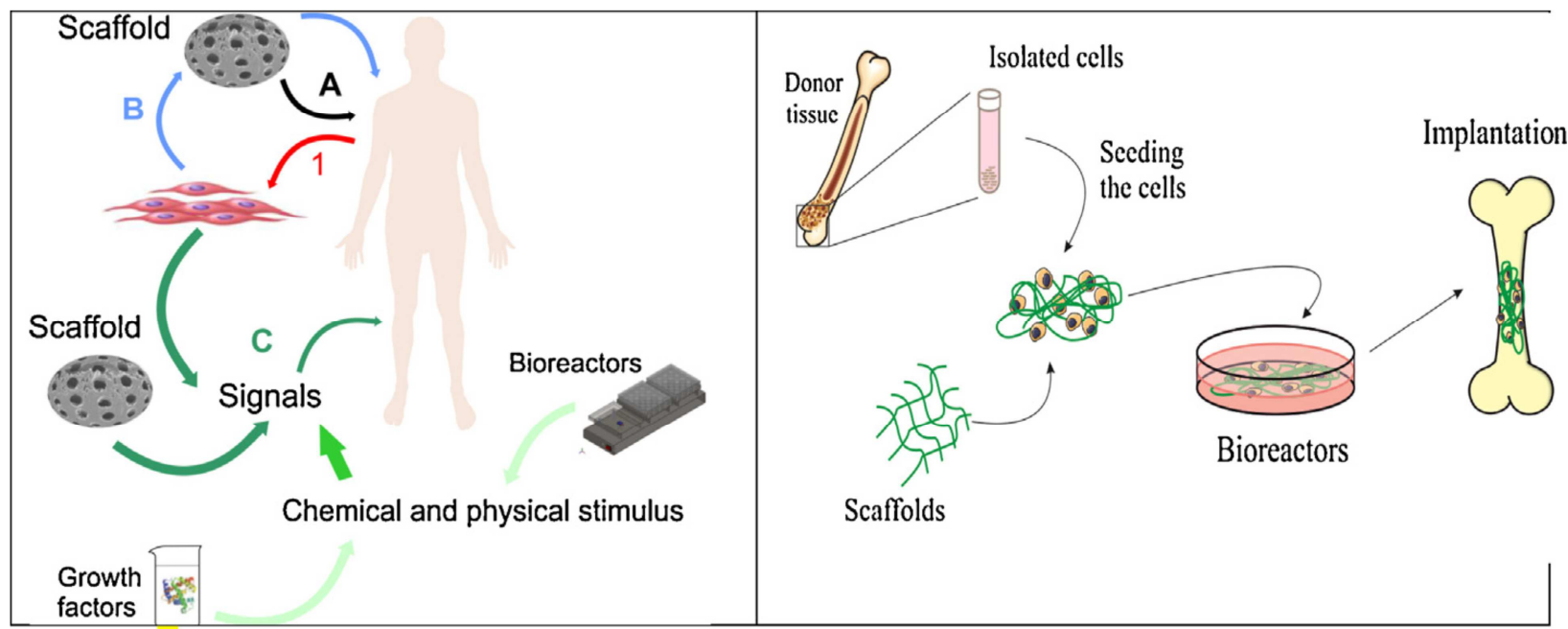

Рис.3.1. Схема двух направлений тканевой инженерии восстановления костной ткани ( Ribeiro, C.; Sencadas, V.; Correia, D. M.; Lanceros-Méndez, S. 2015)

На рисунке слева показано, что скафолд может быть имплантирован напрямую в дефект кости (путь А), может предварительно насыщатся остеогенными клетками (путь В), взятыми непосредственно у пациента, и различными химическими и физическими стимуляторами (путь С). Справа показана другая перспективная стратегия восстановления или регенерации поврежденной кости: предварительно осуществлен сбор здоровых клеток (дифференцированных остеогенных или стволовых клеток), культивируются эти клетки в соответствующем скаффолде для роста in vitro в биореакторе, который обеспечит подходящие биохимические и физические стимуляторы, с последующей имплантацией скафолда в дефект кости. Основная цель этой стратегии - воссоздание окружения костной ткани, включая биохимический и, например, электромеханический стимулятор.

В последние годы разработаны технологии выделения ростовых факторов, таких как трансформирующий фактор b-3 и его аналоги - костные морфогенетические протеины bone morphogenic proteins (BMPs/BMP-2 и ВMP-7 (ОР-1)), что позволяет использовать их в клинической практике для расширения зоны и скорости костной репарации при проведении трансплантации. Интраоперационное применение клеточных технологий на основе взрослых стволовых клеток получило широкое распространение при лечении застарелых и многооскольчатых переломов. Теоретически использование взрослых клеток-предшественников остеогенеза в достаточном количестве в комбинации с подходящей матрицей может быть более эффективным по сравнению с традиционной аутологичной пересадкой костной ткани. Однако подобные технологии требуют сегодня законодательного обеспечения, а также значительной финансовой поддержки. 
Школа Илизарова всегда придерживалась концепции достаточности внутренних резервов организма для сращения перелома конечности и обеспечения оптимальных условий для репаративной регенерации кости, которая заключается в следующем:

• абсолютная, желательно закрытая, репозиция костных отломков;

- стабильная фиксация костных фрагментов;

- атравматичное оперативное вмешательство;

• полноценное кровоснабжение зоны перелома или удлинения конечности;

• оптимальный темп и ритм дистракции;

• функциональная нагрузка конечности в процессе лечения.

Соблюдение всех этих условий в максимальной степени обеспечивает чрескостный остеосинтез аппаратом Илизарова, хотя и и другие технологии остеосинтеза декларируют и стремятся к выполнению оптимальных условий.

Сроки консолидации при переломах длинных трубчатых костей достигают 4-6 месяцев и нередко диагносцируется замедление репаративной регенерации, которое грозит формированием ложного сустава.

Экономическая целесообразность является основой совершенствования методов остеосинтеза в направлении индуцирования остеогенеза. В 2001 г. по предложению Д.А. Попкова в РНЦ «ВТО» им. акад. Г.А. Илизарова (г. Курган, Россия), а затем в Детском ортопедическом центре г. Нанси (Франция) начали удлинять конечности с помощью напряженного интрамедуллярного армирования длинных трубчатых костей спицами. В результате отмечено усиление репаративного остеогенеза вокруг спиц и сокращение сроков консолидации переломов. С 2004 г. началось активное использование интрамедуллярного армирования спицами с биоактивным кальций-фосфатным покрытием при лечении различных заболеваний в г. Кургане, а затем и в клинике Томского филиала РНЦ «BТО» им. акад. Г.А. Илизарова [Попков Д.А., 2005; Popkov D. et al., 2009].

По нашему мнению, интрамедуллярный остеосинтез спицами с биоактивным покрытием выполняет две основные функции - обеспечивает дополнительную стабильность костных фрагментов, а также все остеокондуктивные и остеоиндуктивные условия для репаративной регенерации костной ткани, присущие биоматериалам на основе гидроксиапатита.

С экономической точки зрения, технология изготовления спиц с биоактивным кальций-фосфатным покрытием - достаточно недорогой процесс [Гузеев В.В. и др., 2000; Гузеева Т.И. и др., 2009], а интрамедуллярное положение имплантата исключает необходимость дополнительного культивирования дорогостоящих ростовых и клеточных факторов. 
Ретикулярная ткань, которая заполняет костномозговой канал, обладает высокой пластичностью, и любая травма, являясь пластическим раздражителем, стимулирует функции клеток эндоста и костного мозга в процессе восстановления целостности поврежденной кости. В репаративном костеобразовании ведущая роль принадлежит камбиальным элементам эндоста при относительно слабой реакции со стороны периоста и параоссальных тканей. Именно за счет эндостальных элементов устанавливается связь между отломками и соединительнотканным регенератом [Илизаров Г.А. и др., 1986; Шрейнер А.А., 1995]. Реактивное же воспаление по периферии кости можно рассматривать как приспособительный акт, вызывающий гиперемию и повышение тканевого метаболизма, что способствует ускоренной дифференцировке остеогенных клеток и формированию соединительной ткани. Как мы уже отмечали, повышенный уровень обменных процессов, а следовательно, и репаративного остеогенеза в поврежденной конечности сохраняется в течение 1 месяца, а затем постепенно снижается. Метод интрамедуллярного напряженного армирования спицами с биоактивным ГАпокрытием позволяет влиять на активность костного мозга, стимулируя эндостальное костеобразование. Данный метод остеоиндукции отличается малой травматичностью, не повреждает a. nutricia, исключает возможность замедленной консолидации, т.е. обеспечивает профилактику формирования ложного сустава, вторичных деформаций кости, и гарантирует раннюю функциональную активность пациента.

Для образования костной ткани на керамической поверхности имплантата необходимо обеспечить адгезию соответствующих молекул. Известно, что структура кости иерархически организована в различных диапазонах длин - от макро- до наномасштаба, поэтому для полного раскрытия возможностей инжиниринга ткани, структура имплантата также должна быть иерархически организована на трех уровнях - макро-, микро- и нано-, причем нанорельеф поверхности должен быть порядка 100 нм, чтобы соответствовать рецепторам клеток, а поры необходимы как микро-, так и макроразмеров. Рекомендуемая величина макропор - не менее 300 мк, что обеспечивает питание и клеточное распространение по поверхности имплантата, а также формирование в нем капилляров.

Изучение эктопического остеогенеза на поверхности керамических имплантатов показало, что образованию костной ткани обязательно должна предшествовать клеточная миграция и ангиогенез, которые наблюдаются только при достаточном количестве макропор, и если их недостаточно, эктопическое образование новой кости может быть заторможено или полностью отсутствовать. Хорошо известно, что материалам, не обладающим порозностью, не присущи остеоиндуктивные свойства. 
Увеличение числа микропор и уменьшение размеров кристаллов способствуют увеличению реактивной поверхности и остеоиндуктивной активности кальцийфосфатного материала.

Высказано достоверное предположение о том, что энергетика биоактивной поверхности имплантата также играет огромную роль в процессе индукции костеобразования. В культуре стволовых стромальных клеток адгезия последних преобладает в области отрицательного заряда поверхности, где и начинается дифференцировка остеобластов, выделяющих в среду компоненты костного матрикса (щелочную фосфатазу, остеокальцин).

В настоящее время установлено, что сразу после имплантации биоматериала на его поверхности абсорбируются белки крови и межклеточного матрикса (рис. 3.2) фибронектин, витронектин, фибриноген, остеокальцин, костные сиалопротеины, иммуноглобулины, альбумин и др. Тип, количество и распределение абсорбируемых белков в значительной степени зависят от физико-химических свойств поверхности биоматериала: от химического состава, электрического заряда, смачиваемости, шероховатости, топографии. Слой абсорбируемых на поверхности биоматериала белков вызывает клеточную адгезию, а также обеспечивает передачу информации клеткам через рецепторы клеточной адгезии - интегрины. Среди семейства интегринов именно фибронектин и витронектин ответственны за адгезию остеобластов и их предшественников к поверхности кальций-фосфатных материалов [Берченко Г.Н., 2010].

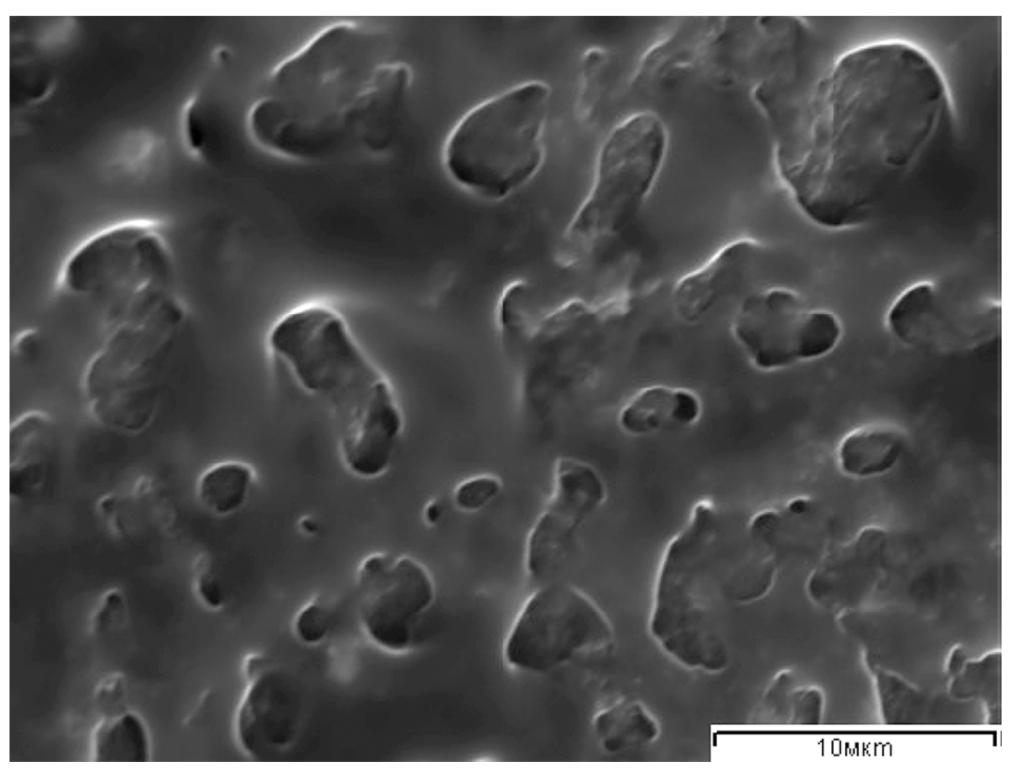

Рис. 3.2. Поверхность интамедуллярной спицы через 26 суток эксперимента (СЭМ). Сквозь отверстия в белковой пленке видно гидроксиапатитовое покрытие. ×3000.

Обсуждая целый ряд существующих гипотез механизма остеоиндукции, мы пока придерживаемся той, которая связывает этот процесс не только с материалом, точнее, с 
дизайном поверхности интрамедуллярной спицы, но и с биологическим явлением в виде воспалительной реакции, происходящей после имплантации биоматериалов [Попков А.В., Осипенко A.B., 2008;], а тем более при травме кости. A.I. Caplan и B.D. Boyan (1994) выдвинули гипотезу о том, что начальный воспалительный ответ после имплантации биоматериала стимулирует факторы, притягивающие мезенхимальные стволовые клетки. Одним из них может быть простагландин E2 (PGE2), который вырабатывается макрофагами, присутствующими вокруг биоматериалов во время воспалительной фазы [Thomsen P., Gretzer C., 2001; Refai A.K. et al., 2004]. Сообщалось, что микрошероховатая поверхность, уникальная для остеоиндуктивных материалов, стимулирует продукцию PGE2 макрофагами [Thomsen P., Gretzer C., 2001], а PGE2 обладает хемотаксическими свойствами в отношении мезенхимальных стволовых клеток человека и стимулирует их остеогенную дифференцировку.

Алгоритм стимулирования остеогенеза можно проиллюстрировать следующим образом:

\section{Микроповреждение костного мозга во время имплантации спиц с} биоактивным покрытием

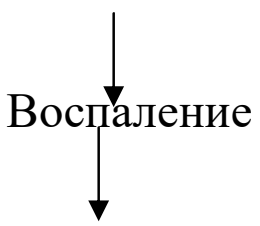

Вторжение в зону имплантата воспалительных клеток (макрофагов)

Формирование на поверхности имплантата слоя активных белков, высвобождение цитокинов воспалительных клеток, включая простагландин $\mathrm{E}_{2}\left(\mathrm{PGE}_{2}\right)$, увеличенное микрошероховатостью

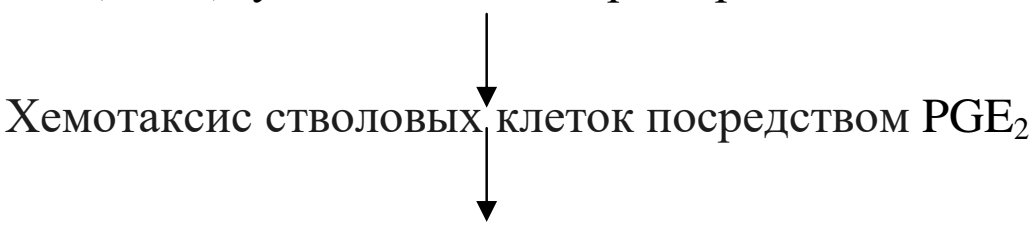

Остеогенное дифференцирование стволовых клеток

Образование новой кости (формирование органического матрикса и его минерализация)

Ремоделирование кости после удаления интрамедуллярной спицы 
В результате имплантации вокруг спицы при интрамедуллярном армировании формируется своеобразный костный футляр за счет индуцированного локального остеогенеза (Рис.3.3).

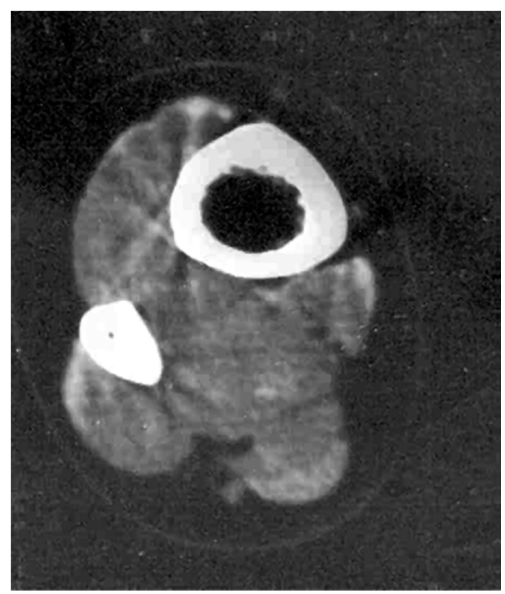

$a$

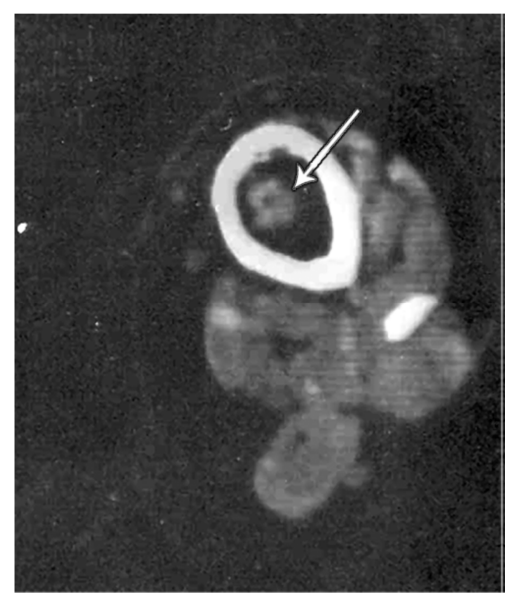

6

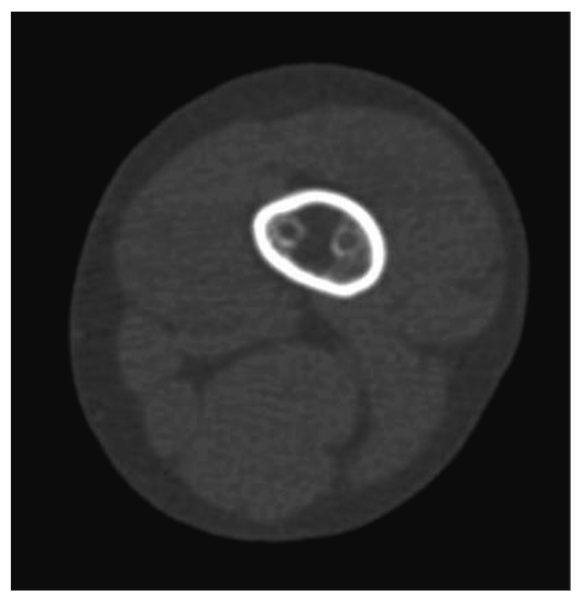

B

Рис.3.3. Компьютерные томограммы костей нижней конечности: а - интактная голень собаки на границе средней и нижней трети диафиза; б - голень собаки после удаления интрамедуллярной спицы; в - бедро пациента вне зоны перелома после удаления интрамедуллярных спиц. Отчетливо видны тени локального костеобразования вокруг канала на месте удаленной интрамедуллярной спицы.

Толщина минерализованной стенки этого «футляра» достигает 3 мм, а в дальнейшем он прочно связывается с эндостом и костномозговой канал по всей длине интрамедуллярной спицы заполняется губчатой костью (Рис.3.4 ).

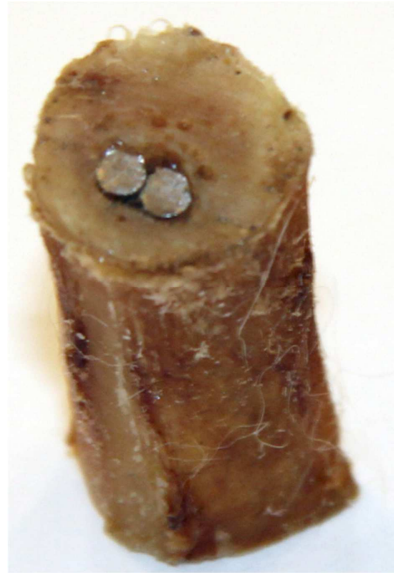

a

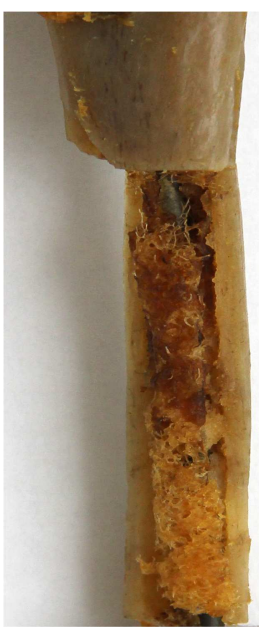

6

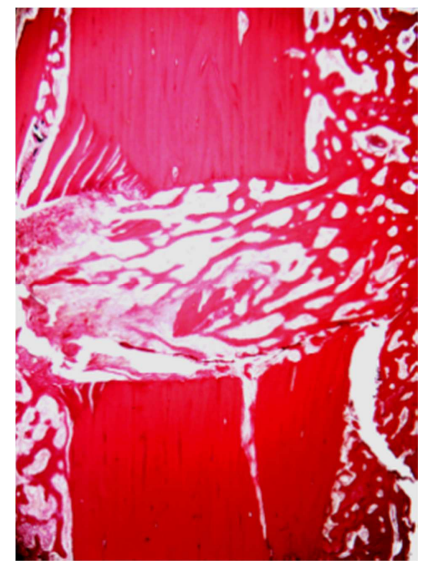

B

Рис. 3.4. Препараты большеберцовой кости собаки: а - на поперечном срезе кости видно, что костномозговой канал полностью заполнен губчатым веществом костной ткани; б - на всем протяжении костномозгового канала сформировался своеобразный костный «штифт» (кортикальный слой кости частично удален); в -микрофото межотломкового пространства в интермедиарной области после перелома голени собаки через 14 суток после комбинированного интрамедуллярного остеосинтеза биоактивным имплантатом (отсутствие краевого некроза костных фрагментов, интермедиарное пространство заполнено губчатым веществом кости, формирующимся со стороны костномозгового канала и от поверхности костных фрагментов) - сравните с рис.2.1. 
Этот своеобразный костный «штифт» обеспечивает быструю консолидацию перелома и возможность полной нагрузки на поврежденную конечность уже в течение месяца после операции [Попков А.В., Попков Д.А..2012]. На этом основано появление новых медицинских технологий с использованием биоактиных интрамедуллярных имплантатов, которые не только гарантируют положительный результат лечения переломов длинных трубчатых костей, но и осуществляют это в очень короткие сроки, сократив период остеосинтеза аппаратами внешней фиксации вплоть до 2-3 недель.

Известно, что остеоиндуктивная и остеокондуктивная активность такого имплантата зависит от биологической активности его поверхности: химического состава, еe шероховатости, величины пор, адгезии покрытия с подложкой [Anselme K., Noel B., Hardouin P. 1999; Nishiguchi S, et al.,2003; Fujibayashi S, et al., 2004]. Эти авторы продемонстрировали in vitro, что на гладких поверхностях имплантатов с канавками глубиной в 5 мкм клетки выстраиваются параллельно их направлению, тогда как на гладкой поверхности с отсутствием канавок остеогенные клетки, как правило, не задерживаются In vivo шероховатая поверхность имплантата также обеспечивает повышенный остеогенез и прочность фиксации клеток [Takemoto M., et al., 2006; Hacking S.A., et al., 2003]. Доказано, что металлический имплантат, поверхность которого покрыта наночастицами гидроксиапатита стимулирует остеогенную активность костного мозга, однако в современной литературе практически нет сведений об особенностях костеобразования на гидроксиапатите, нанесенном по различным технологиям.

Сравнительный гистологический и биомеханический тесты, проведенные нами, были призваны сделать объективную количественную оценку активности различных технологий покрытия имплантатов в отношении репаративного остеогенеза.

\section{2. Механические свойства покрытия}

Эти свойства наряду с физико-химическими характеристиками поверхности имплантата определяют успех работы хирурга в травматологии и ортопедии.

Покрытие должно удовлетворительно прилипать к подложке независимо от предназначенной функции. В частности, механическая стабильность СаР-покрытий должна быть достаточно высокой, для того чтобы поддерживать после хирургической установки имплантатов их биоактивную функциональность.

Способов тестирования механической прочности связей покрытия с подложной великое множество. Например, испытание на растяжение в соответствии с такими стандартами, как ASTM C633, - обычная процедура определения количественных величин адгезии СаР-покрытия к металлическим подложкам. Однако этот метод может применяться только для покрытий толщиной более 0,38 мм [Rohanizadeh R. et al., 2005]. 
Среди наиболее ценных методов получения дополнительной информации о механических свойствах СаР-покрытий можно назвать тестирование на усталость и царапины. Усталостное поведение часто исследуют методом трехточечного изгиба в ИТЖ в условиях циклического нагружения с целью моделирования прерывающихся сил, которые действуют на имплантат. Тем самым получают сведения о гибкости при изгибе, внутренних напряжениях и тенденциях к образованию трещин [Wolke J.G.C. et al., 1997; Clemens J.A.M. et al., 1999]. Тестирование царапиной обычно выполняют для того, чтобы иметь представление о механизме деформации $\mathrm{CaP}$-покрытий при напряжении сдвига [Wu T.W., 1991]. Разрушение вязкого покрытия, по S.J. Bull (1991), характеризуется появлением небольших зон подложки без покрытия, которые ограничиваются дорожкой царапины, в то время как разрушение хрупкого покрытия более экстенсивно и часто простирается за пределы царапины. Критические нагружения при «вязком» разрушении намного выше, чем при «хрупком». Этот тест - хорошее сравнительное испытание для получения информации об основных режимах разрушения. В то же время он менее пригоден для определения абсолютных величин критических нагрузок вследствие своей зависимости от многочисленных параметров эксперимента, связанных с самим тестированием и спецификой системы «покрытие - подложка» [Steinmann P.A. et al., 1987; Wang J. et al., 2004].

Всего было задокументировано более 350 различных методов изучения адгезии покрытия, что подтверждает сложность ее тестирования. K.L. Mittal (1993) заявил, что любой из этих методов может ранжировать образцы «покрытие - подложка» в серии, но лучшим испытанием был бы тот, который как можно ближе моделировал бы условия напряжения использования. С этой точки зрения простой, но полезный метод был успешно применен для характеристики адгезии и механической прочности биомедицинских СаР-покрытий в условиях, максимально приближенных к клиническим [Leeuwenburgh S.C.G. et al., 2006]. В этом исследовании адгезию пористых электронапыленных СаР-покрытий оценивали посредством имплантации и немедленной эксплантации стоматологических шурупов из бедренных мыщелков трупа козы. Определение уровня адгезии, а также когезии СаР-покрытий посредством таких методов, как сканирующая электронная микроскопия, позволило прогнозировать их механическое поведение при установке стоматологических имплантатов.

Гидроксиапатитовые покрытия индуцируют костеобразование вокруг имплантата, что обеспечивает больший контакт кости с ним [Thomas K.A. et al., 1989; Jansen J.A. et al., 1991; Dhert W.J.A. et al., 1993] и улучшает его фиксацию [Søballe K. et al., 1993; 1996] 
практически без каких-либо промежутков между костью и имплантатом [Søballe K. et al., 1991; Stephenson P.K. et al., 1991].

В некоторых случаях связь с окружающей костью (особенно с губчатым веществом) становится настолько прочной, что при выкручивании шурупа на нем остаются значительные куски губчатого вещества (рис. 3.5).

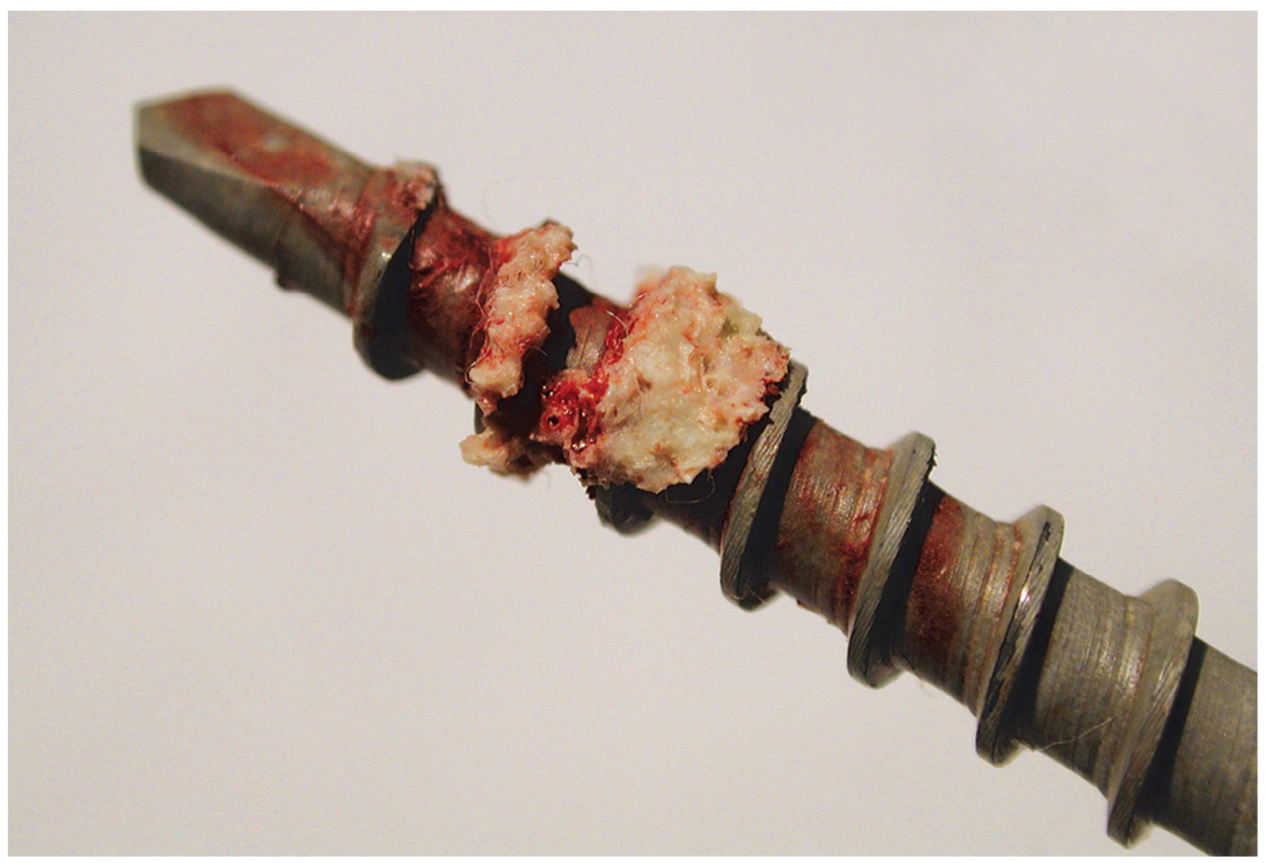

Puc. 3.5. Стержень-шуруп с наногидроксиапатитовым покрытием сразу после удаления из губчатого вещества кости при демонтаже аппарата Илизарова (собственное наблюдение). 
$\mathrm{C}$ увеличением толщины общие механические характеристики СаР-покрытий постепенно сдвигаются от тонкопленочных с внутренне присущим некоторым несоответствием механических свойств подложки и покрытия к объемным керамическим, характеризуемым бо́льшими расхождениями между покрытием и подложкой в таких свойствах, как модуль упругости и коэффициент теплового расширения. Другими словами, СаР-покрытия теряют специфические достоинства тонких пленок на металлических подложках. Более того, типичная гетерогенная кристалличность способствует гетерогенному растворению плазменно-напыленных СаР-покрытий и износу третьего тела за счет высвобождения расшатанных кристаллических частиц фосфата кальция вокруг имплантата и остеолиза [Gross K.A. et al., 2002].

Поэтому альтернативные методы нанесения СаР-покрытий тестировались in vivo с начала 90-х гг. прошлого столетия с использованием различных экспериментальных моделей. Результаты этих исследований подтверждают благоприятные биологические эффекты, т.е. остеокондуктивные способности «набрызганных» [Yang Y. et al., 2005] и биомиметических [Barrere F. et al., 2003] СаР-покрытий. Остеоиндуктивный потенциал биомиметических СаР-покрытий при загружении фосфата кальция фактором роста (BMP2) был подтвержден в исследованиях in vivo [Liu Y. et al., 2005].

Главным достоинством биоактивных СаР-покрытий является практически отсутствие сообщений об отрицательных результатах их применения. Как правило, протезы с СаРпокрытием, используемые в ортопедической хирургии, функционируют как лучшие из цементных или бесцементных систем и систем без покрытия. При этом нанорельеф поверхности должен быть сформирован из кальций-фосфатных глобул диаметром не менее 10 нм для протекания протеиновых реакций и не более 100 нм, чтобы соответствовать рецепторам клеток, поскольку в клетках человека величиной несколько микронов различные химические реакции протекают в наноразмерных объемах. Кристаллы ГА образуют мезорельеф поверхности покрытия имплантата, влияющий на адгезию и дифференцировку стволовых клеток и формирование ткани, с размером пор в диапазоне от 5 до 100 мкм [Маслюк А.И. и др., 2010]. Соотношение Са/Р в таких покрытиях должно быть в пределах 1,67-2,1, что соответствует естественной костной ткани. И все эти условия должны сочетаться с высокой эластичностью и достаточной адгезией к основному материалу.

Большинство технологий нанесения покрытия не позволяет получить результаты, одновременно удовлетворяющие всем перечисленным требованиям.

Эластичность композитных материалов толщиной $70 \pm 10$ мкм мы исследовали с помощью прибором Изгиб (Градиент-Техно, Россия) согласно рекомендациям ISO 1519. 
За значение показателя эластичности покрытия принимали наименьший диаметр стержня, изгибание вокруг которого не приводило к механическому разрушению или отслаиванию композитного покрытия.

Изучение адгезионных свойств полученных композитных покрытий проводили согласно рекомендациям ISO 13779-4 "Implants for surgery - Hydroxyapatite - Part 4: Determination of coating adhesion strength" . Полученные данные представлены в таблице 3. 1.

Таблица 3.1. Механические свойства композитных покрытий.

\begin{tabular}{|l|c|c|l|}
\hline $\begin{array}{l}\text { Технология покрытия } \\
\text { имплантата }\end{array}$ & $\begin{array}{l}\text { Адгезионная } \\
\text { прочность, МПа }\end{array}$ & $\begin{array}{l}\text { Деформация } \\
\text { растяжении, \% }\end{array}$ & Эластичность, мм \\
\hline $\begin{array}{l}\text { Технология МДО [Liu } \\
\text { Х.; Chu P.K.б 2004] }\end{array}$ & $28-30$ & Менее 3 & $3-4$ \\
\hline $\begin{array}{l}\text { Плазменное } \\
\text { напыление [Liu X.; Chu } \\
\text { Р.К.б 2004] }\end{array}$ & $19-23$ & Менеe 3 & $3-4$ \\
\hline $\begin{array}{l}\text { Сополимер VDF-TeFE, } \\
\text { масса 50 \% }\end{array}$ & $21.2 \pm 3.6$ & $35.3 \pm 1,0$ & 2 \\
\hline $\begin{array}{l}\text { Сополимер VDF-TeFE, } \\
\text { масса 35\% }\end{array}$ & $15.4 \pm 1.8$ & $16.3 \pm 1,5$ & 2 \\
\hline $\begin{array}{l}\text { Сополимер VDF-TeFE, } \\
\text { масса 25\% }\end{array}$ & $9.9 \pm 2.4$ & $5.9 \pm 1.2$ & 3 \\
\hline
\end{tabular}

Поскольку главная цель исследований, связанных с применением имплантатов в ортопедии и хирургической стоматологии, - это достижение соответствующей фиксации их в окружающей кости, для определения ее степени желательны механические испытания, которые позволяют получить количественные показатели [Dhert W.J.A., Jansen J.А., 1999]. В настоящее время для оценки механических свойств извлеченных имплантатов доступны различные методы. Испытания на выталкивание и отрыв - это простые испытания, которые можно провести с помощью недорогого оборудования. В испытаниях на выталкивание измеряют силу, требуемую для того, чтобы сдвинуть имплантат в окружающей кости, и рассчитывают так называемую прочность выталкивания (рис. 3.6). 


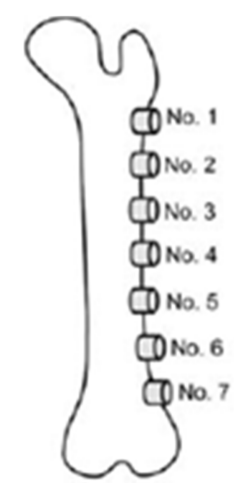

$a$

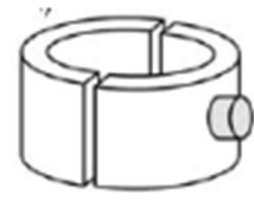

6

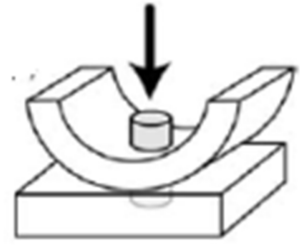

$B$

Puc. 3.6. Испытание на выталкивание (схема): $a$ - бедренная кость с имплантатами; $\sigma$ - фрагмент извлеченной бедренной кости с имплантатом; в - собственно испытание на выталкивание [Nishiguchi S. et al., 2001].

В испытаниях на отрыв, в которых нагрузку прикладывали в направлении, перпендикулярном границе раздела «ткань - биоматериал», может быть измерена прочность связи между костью и биоматериалом (рис.3.7).

Наши испытания на отрыв интрамедуллярно расположенных имплантатов проведены на половозрелых собаках в рамках выполнения Государственного задания М3 РФ от 29.12.2014 и в соответствии с «Правилами проведения работ с использованием экспериментальных животных», утвержденных приказом Министерства здравоохранения СССР № 755 от 12 августа 1977 г. и Европейской конвенции по защите позвоночных животных, используемых для экспериментальных целей (Страсбург, 1986).

Оперативное вмешательство полностью копировало технологию интрамедуллярного армирования осуществляемую в клинике. Спустя 4 недели после имплантации спицы удаляли с измерение прилагаемых усилий динамометром ДЭП3-1Д1У-1(Россия). Расчет напряжения отрыва спицы $(P)$ проводили по формуле:

$$
P=\frac{F}{L \pi d}(2)
$$

Где: $F$ - усилие отрыва; $L$ - длина спицы; $d$ - диаметр спицы.

Полученные результаты представлены в таблице 3.2. 
Таблица 3.2. Уровень усилия при отрыве спиц с ГА покрытием нанесенного по разным технологиям

\begin{tabular}{|c|c|c|c|c|c|}
\hline $\begin{array}{c}\text { Технология } \\
\text { ГА } \\
\text { покрытия } \\
\text { спиц }^{\times}\end{array}$ & $\begin{array}{c}\text { Длина } \\
\text { спицы (мм) }\end{array}$ & $\begin{array}{c}\text { Диаметр } \\
\text { спицы } \\
\text { (мм) }\end{array}$ & $\begin{array}{c}\text { Усилие отрыва } \\
\text { (H) }\end{array}$ & $\begin{array}{c}\text { Площадь } \\
\text { поверхности } \\
\text { Спицы (мм²) }\end{array}$ & $\begin{array}{l}\text { Напряжение } \\
\text { отрыва (ГПа) }\end{array}$ \\
\hline 1 & $44,25 \pm 7,2$ & 1 & $36,725 \pm 2$ & $138,72 \pm 23,08$ & $353,6 \pm 11$ \\
\hline 2 & $60,66 \pm 0,1$ & 1,6 & $95,1 \pm 4$ & $304,79 \pm 4,74$ & $312,2 \pm 20$ \\
\hline 3 & $70,0 \pm 17,8$ & 1,4 & $126 \pm 4$ & $307,72 \pm 78,22$ & $421,0 \pm 17$ \\
\hline 4 & $70,0 \pm 13,5$ & 1,8 & $203,5 \pm 9$ & $396,1 \pm 76,0$ & $400,6 \pm 27$ \\
\hline 5 & $81,75 \pm 22,3$ & 2 & $258,9 \pm 9$ & $513,3 \pm 76,53$ & $494,7 \pm 28$ \\
\hline 6 & $71,4 \pm 18,4$ & 2 & $219,6 \pm 7$ & $419,2 \pm 115,59$ & $514 \pm 20$ \\
\hline 7 & $75,0 \pm 8,2$ & 1,6 & $14,09 \pm 5$ & $393,5 \pm 41,02$ & $351,1 \pm 18$ \\
\hline
\end{tabular}

* 1 - Сталь+ (полилактид смешанный с гидроксиапатитом); 2 - Сталь+Ті(титановый слойпраймер)+ГА(микродуговое оксидирование)+ГА(высокочастотное магнетронное распыление); 3 Сталь+Ті(титановый слой-праймер)+ГА(высокочастотное магнетронное распыление); 4 - Сталь + +ГА(высокочастотное магнетронное распыление); 5 - Титан+ГА(микродуговое оксидирование); 6 - Сталь+( сополимер тетрафторэтилена с винилиденфторидом смешанный с гидроксиапатитом); 7 - сталь.

Результаты исследований показывают, что наименьшее усилие отрыва демонстрируют спицы с меньшей шероховатостью ГА покрытия и стальные спицы без покрытия. Сформированный микропористый кальций фосфатный слой на поверхности спиц изготовленного из титана более чем на $140 \%$ увеличивает значение показателей прочности сцепления по сравнению со спицами без покрытия. Стальные имплантаты с композитным сегнетоэлектрическим биологически активным покрытием с содержанием сополимера VDF-TeFE 35 \% продемонстрировали результаты прочности сцепления с костной тканью сравнимые с результатами для титановых спиц с покрытием, изготовленным по технологии МДО. Значительные отличия в показателях прочности сцепления свидетельствует о высокой биологической активности процессов остеоинтеграции вокруг КФ покрытий сформированных на спицах. Гистологические исследования тканей вокруг спиц это подтверждают.

Для сравнения добавим, что после того как T. Nakamura [Nakamura T, Nishiguchi S, 1999] в 1985 разработал оригинальный метод отрыва имплантата с биоактивной поверхностью от костного ложа (рис. 3.7) несколько исследователей в Киотском университете провели это испытание, чтобы оценить прочность связывания с костью различных биоматериалов, таких как биоактивная керамика [Kitsugi T. et al., 1996], титановый сплав [Takatsuka K. et al., 1995], титановый сплав, покрытый биоактивными 
материалами [Takatsuka K. et al., 1995], химически и термически обработанный титан [Nishiguchi S. et al., 1999; Fujibayashi S. et al., 2001]. Результаты представлены в таблице 3.3 .

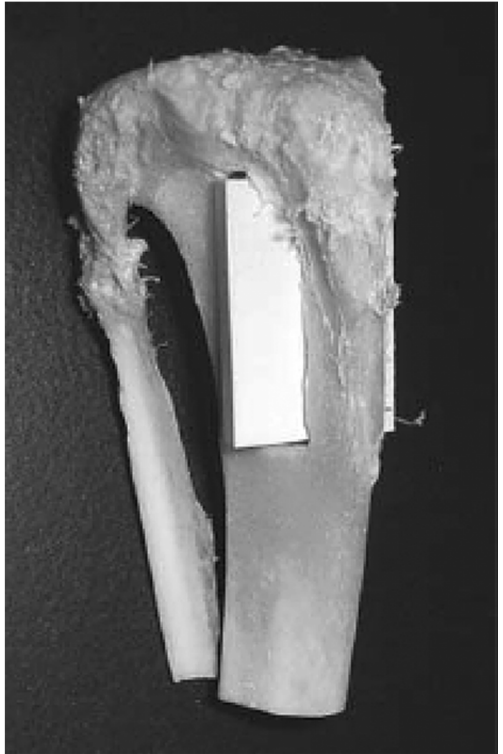

$a$

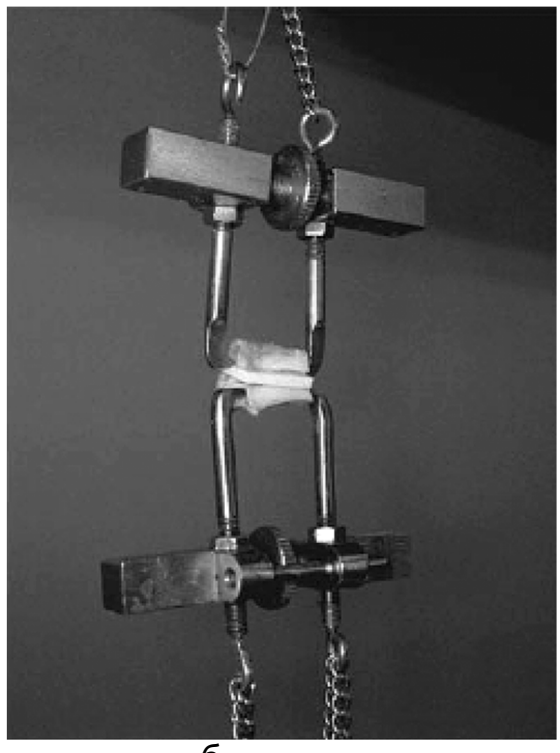

6

Рис. 3.7. Испытание на отрыв: а - большеберцовая кость кролика с имплантатом; б - приложение растягивающей нагрузки с удержанием переднего и заднего кортекса до наступления отрыва [Nakamura T. et al., 1985, 1999].

Таблица 3.3. Уровень суммарного усилия при отрыве различных биоматериалов (N)

\begin{tabular}{|c|c|c|c|c|c|}
\hline & 4 недель & 8 недель & 10 недель & 16 недель & 25 недель \\
\hline $\begin{array}{l}\text { AW стекло-керамика (AW- } \\
\text { GC) (Nakamura et al., 1985) }\end{array}$ & & $74 \mathrm{~N}$ & & & $81,5 \mathrm{~N}$ \\
\hline $\begin{array}{l}\text { Плотный гидроксиапатит } \\
\text { (Nakamura et al., 1985) }\end{array}$ & & $62 \mathrm{~N}$ & & & $79,0 \mathrm{~N}$ \\
\hline $\begin{array}{l}\text { Биостекло 45S5 (Nakamura } \\
\text { et al., 1985) }\end{array}$ & & $27,5 \mathrm{~N}$ & & & \\
\hline $\begin{array}{l}\text { Оксид алюминия (Nakamura } \\
\text { et al., 1985) }\end{array}$ & & $1,3 \mathrm{~N}$ & & & \\
\hline $\begin{array}{l}\text { ß-трикальций фосфат } \\
\text { (Kitsugi et al., 1996) }\end{array}$ & & & $31,65 \mathrm{~N}$ & & $47,0 \mathrm{~N}$ \\
\hline $\begin{array}{l}\text { Ti6Al4V (Takatsuka } \text { et al., } \\
\text { 1995) }\end{array}$ & $0,014 \mathrm{~N}$ & $0,029 \mathrm{~N}$ & & $3,3 \mathrm{~N}$ & $28,5 \mathrm{~N}$ \\
\hline $\begin{array}{l}\text { Ti6Al4V с покрытием из } \\
\text { биостекло (Takatsuka et al., } \\
\text { 1995) }\end{array}$ & & $10,4 \mathrm{~N}$ & & $27,2 \mathrm{~N}$ & \\
\hline $\begin{array}{l}\text { Ti6Al4V c AW-покрытием } \\
\text { (Takatsuka et al., 1995) }\end{array}$ & & $20,3 \mathrm{~N}$ & & $23,9 \mathrm{~N}$ & \\
\hline $\begin{array}{l}\text { Ti6Al4V с ТСР покрытием } \\
\text { (Takatsuka et al., 1995) }\end{array}$ & & $39,1 \mathrm{~N}$ & & $42,3 \mathrm{~N}$ & \\
\hline \multicolumn{6}{|l|}{ Чистый титан } \\
\hline (Nishiguchi et al., 1999) & $0 \mathrm{~N}$ & $0,2 \mathrm{~N}$ & & $3,3 \mathrm{~N}$ & $0.237 \mathrm{H}$ \\
\hline (Fujibayashi et al., 2001) & & $0 \mathrm{~N}$ & & $0,388 \mathrm{~N}$ & \\
\hline \multicolumn{6}{|l|}{$\begin{array}{l}\text { Ті после щелочной и } \\
\text { термообработки }\end{array}$} \\
\hline (Nishiguchi et al., 1999) & $0,688 \mathrm{~N}$ & $27,1 \mathrm{~N}$ & & $41,3 \mathrm{~N}$ & $53,875 \mathrm{~N}$ \\
\hline
\end{tabular}




\begin{tabular}{|l|l|l|l|l|l|}
\hline (Fujibayashi et al., 2001) & & $14,438 \mathrm{~N}$ & & $29,60 \mathrm{~N}$ & \\
\hline $\begin{array}{l}\text { Ti после безнатриевой } \\
\text { щелочной и термообработки } \\
\text { (Fujibayashi } \text { et al., 2001) }\end{array}$ & $12,713 \mathrm{~N}$ & $20,488 \mathrm{~N}$ & & $18,562 \mathrm{~N}$ & $13,550 \mathrm{~N}$ \\
\hline
\end{tabular}

Данные этой таблицы показали, что связь кости с имплантатом на протяжении времени только увеличивалась, за исключением чистого титана. Наибольший уровень отрыва имплантата наблюдали при использовании стекло-керамики и, также как и в наших исследованиях, плотного гидроксиапатита - порядка 80 ньютон, но только через 25 недель фиксации при площади контакта около 150 мм² ( несколько выше 500 ГПа).

\section{3. Морфологические особенности костеобразования вокруг интрамедуллярных имплантатов.}

Гистологические исследования интрамедуллярного пространства подтверждают, что вокруг титановых спиц с ГА покрытием формируется мощный костный «футляр» из губчатого вещества, который срастается с эндостальной поверхностью костномозгового канала (Рис.3.8а). Поверхность имплантаты из биотолерантного материала (нержавеющая сталь) отделяется от смежной кости мощным слоем фиброзной ткани, репаративная регенерация (костный футляр) кости происходит на некотором расстоянии от имплантата (дистантный остеогенез) и значительно менее выражен. Гистологическая картина вокруг стального имплантата, покрытого VDF-TeFE с ГА сравнима с картиной вокруг титановых спиц с покрытием по технологии МДО (Рис.3.8 б, в ) - такой имплантат не вызывает образования фиброзной ткани. Проведенный анализ показал, что наличие рельефной архитектоники и пор на поверхности композитного кальций-фосфатного напыления способствует отсутствию соединительнотканного футляра и формированию костной муфты достаточного плотного трабекулярного строения, как и в случаях с кальций-фосфатными покрытиями по технологиит МДО. Оба варианта покрытий обладают адгезивными свойствами, обладают остеоиндуцирующим действием и способствуют остеоинтеграции имплантата.

Гистологическая картина вокруг стального имплантата с композитным покрытием с содержанием VDF-TeFE 35 \% сравнима с гистологической картиной вокруг титановых спиц с КФ покрытием, изготовленным по технологии МДО. Костная муфта плотного трабекулярного строения плотно прилегает к поверхности имплантата без образования кольца из фиброзной ткани. Образование костной муфты плотного трабекулярного строения свидетельствует о высоких остеоиндуктивных свойствах покрытия. 


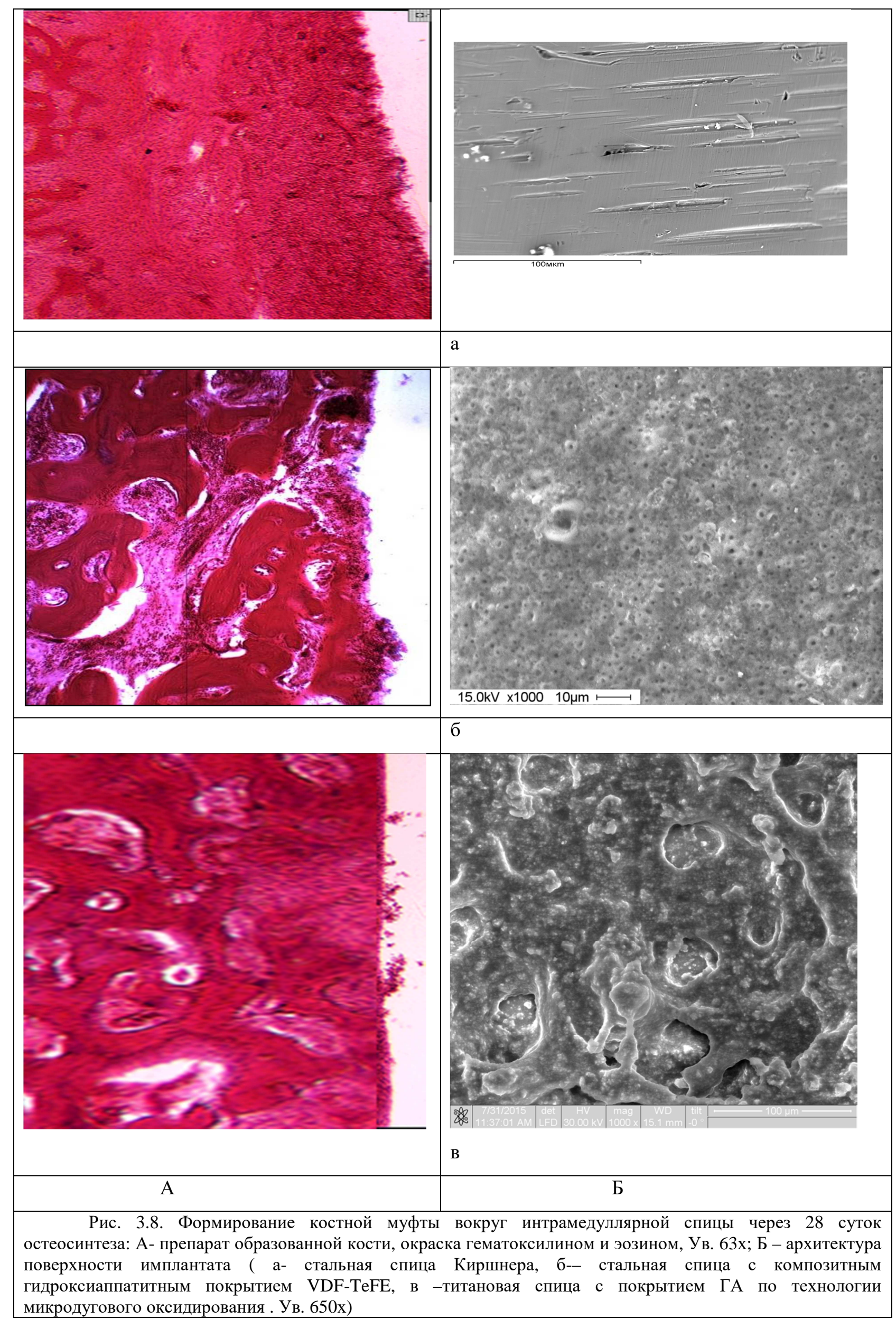


Безусловно, высокие остеоиндуктивные свойства стальных спиц с композитным покрытием, как и в случае с титановым спиц во многом обусловлены развитой поверхностью покрытия. С другой стороны пленка сополимера VDF-TeFE выполняющая роль “грунтовочного” слоя при формирование покрытия надежно защищает металл имплантата от коррозии, что блокирует выход потенциально токсичных продуктов в окружающие ткани. Однако следует принять во внимание и обстоятельство, что на поверхности композитного покрытия а приори количество ионов кальция и фосфора необходимых для остеогенной дифференцировке меньше во-первых поскольку биологически активный наполнитель в нашем случае представлял собой высоко кристаллический гидроксиапатит растворимость которого в физиологических средах существенно ниже чем аморфных фосфатов кальция на поверхности титановых спиц, а, во-вторых, меньше и его содержание поскольку материал для покрытия является композитным.

Известен еще один объективный факт положительного влияния интрамедуллярного армирования спицами с ГА покрытием. При травме, как и при удлинении нижних конечностей методом Илизарова, наблюдается выраженный остеопороз. Наши наблюдения за пациентами даже пожилого возраста показали, что остеоинтеграция имплантата и образование нового костного «штифта» из губчатого вещества в костномозговом канале исключает развитие остеопороза в течение нескольких лет и минеральная плотность диафиза кости значительно превосходит исходные данные. Это сразу наводит на мысль о возможном методе борьбы с остеопорозом.

Далее мы покажем возможности клинического использования нанотехнологий (интрамедуллярное стимулирование репаративного процесса имплантатами с ГАпокрытием) в лечении переломов костей и их последствий. 


\section{ГЛАВА 4.}

\section{ИНТРАМЕДУЛЛЯРНОЕ АРМИРОВАНИЕ ПРИ ЛЕЧЕНИИ ПЕРЕЛОМОВ ДЛИННЫХ ТРУБЧАТЫХ КОСТЕЙ}

Проблема организации и совершенствования медицинской помощи больным с повреждениями опорно-двигательной системы с каждым годом приобретает все большее значение в связи с увеличением количества пострадавших, ростом показателей инвалидности и смертности от травм у лиц трудоспособного возраста [Корнилов Н.В., Шапиро К.И., 2002; Азизов М.Ж., Салиев М.М., 2003; Миронов С.П. с соавт., 2010; Бекчанов С.3. и др., 2009]. Достаточно сказать, что в Российской Федерации ежегодно регистрируется более 20 млн случаев травм и заболеваний костно-мышечной системы.

В структуре общей смертности населения удельный вес травм достигает 14,1 \% [Доклад МЗ РФ «Об итогах работы органов учреждений здравоохранения в 2002 г. и мерах по повышению качества медицинской помощи населению»].

Актуальность проблемы определяется еще и тем, что характер травм и их последствий меняется с тенденцией к утяжелению. Качественные изменения структуры травматизма обусловлены ростом уровня множественных и сочетанных травм. В настоящее время они составляют 16-20\% в числе всех повреждений и 60-80 \% среди причин инвалидности от травм [Корнилов Н.В. и др., 1999; Фадеев Д.И., 1999; Копысова В.А., Каплун В.А., 2000; Агаджанян В.В., 2001; Попова Л.А., Волосатова Т.П., 2005].

По данным Центрального научно-исследовательского института экспертизы и организации труда инвалидов, в медицинской реабилитации нуждается 97,7 \% всех инвалидов от травм и их последствий.

Более 50 \% среди инвалидов от травм составляют пострадавшие с переломами костей конечностей. При этом доминирующее положение занимают травмы бедра и голени [Устьянцев В.И., 2006], чем подтверждается не только их тяжесть, но и в определенной степени несостоятельность существующих методов лечения, реабилитации и организационных форм системы медицинской помощи больным [Цыбуляк Г.Н., 1994; Журавлев С.М., 1997; Ахметьянов Р.Ф., 2005; Гришина Л.П., 2005; Щепин О.П., Тищук E.A., 2005].

В России на протяжении последних 15 лет травмы, их последствия и болезни костномышечной системы стабильно занимают 3-е место по частоте инвалидизации населения, и рассчитывать на существенное снижение травматизма не приходится ввиду объективных причин: частота и тяжесть травм и их последствий с каждым годом увеличиваются; стираются грани различий между тяжестью промышленных и сельскохозяйственных, 
производственных и бытовых травм - все они характеризуются высокой степенью инвалидизации.

Удельный вес инвалидов от травм и ортопедических заболеваний в общей структуре инвалидности составляет 25-30 \%. В результате накопленная инвалидность в 5-10 раз превышает первичную. Рост показателей инвалидности с 46,7 до 56,9 \% при одновременном снижении показателей полной реабилитации инвалидов с 20,9 до 15,4 \% свидетельствует о несостоятельности системы реабилитации и неизбежном накоплении этого контингента. Экономические потери от инвалидности колоссальны. По данным специально проведенных исследований, они составляют 129586 рублей на одного впервые признанного инвалидом от травм опорно-двигательной системы и их последствий и 25529 рублей на одного инвалида, сохраняющего инвалидность после переосвидетельствования.

Создание максимально эффективной системы восстановительного лечения больных с травмой и ортопедическими заболеваниями, обеспечивающей сокращение сроков нетрудоспособности, снижение уровня первичной и накопленной инвалидности, - вот цель, достойная внимания современного демократического государства.

Изучая организацию, средства и способы восстановительного лечения в современной травматологии и ортопедии, мы пришли к глубокому убеждению в том, что наиболее полно отвечает этим требованиям метод чрескостного остеосинтеза, разработанный в РНЦ «ВТО» им. акад. Г.А. Илизарова, и ряд других методов чрескостного и внутрикостного остеосинтеза, основанных на общих принципах, как то:

• полная репозиция отломков;

- атравматичность оперативного вмешательства;

- стабильная фиксация;

• полноценное кровоснабжение;

- функциональная нагрузка;

- стимуляция репаративных процессов.

Однако реальные сроки остеосинтеза продолжают оставаться значительными, а уровень инвалидизации после травм растет во всех регионах страны, о чем свидетельствуют материалы последних съездов травматологов-ортопедов России.

При использовании чрескостного остеосинтеза спицевым или спице-стержневым аппаратом внешней фиксации сроки лечения переломов колеблются от 16-ти до 24-х недель [Котельников Г.П., Миронов С.П., 2008], частота осложнений достигает 21-30,7 \% и инвалидность в зависимости от способа лечения колеблется от 2,9 до 13,64\% [Прокопьев А.Н., 2003]. Например, по г.Кургану, где активно используется метод 
чрескостного остеосинтеза аппаратом Илизарова и успешно работает научноисследовательский институт его имени, сроки лечения больных с переломами длинных трубчатых костей в XXI веке заметно увеличились (Таблица 4.1. ) [Серкова Е.В., 2011].

Таблица 4.1. Сроки временной нетрудоспособности при остеосинтезе перелома аппаратом Илизарова в г. Кургане

\begin{tabular}{|c|c|c|}
\hline Характер перелома & \multicolumn{1}{|c|}{$2005-2007$ г } \\
\hline Закрытый перелом бедра & $181,4 \pm 16,8$ & $213,4 \pm 15,78$ \\
Закрытый перелом голени & $113,6 \pm 7,1$ & $130,517,21$ \\
& & \\
Открытый перелом голени & $145,0 \pm 13,1$ & $163,1 \pm 5,26$ \\
Закрытый перелом плеча & $87,8 \pm 13,4$ & $129,5 \pm 16,59$ \\
Закрытый перелом & & \\
предплечья & $123,5 \pm 12,3$ & $107,5 \pm 8,17$ \\
\hline
\end{tabular}

И причины этого не столько в тяжести травмы, а прежде всего в недостатках организации здравоохранения: резко ограничены штаты травматологов в центральных районных больницах, городских больницах и поликлиниках (вплоть до их отсутствия), уровень квалификации специалистов нового поколения резко снижен, организация деятельности ОМС не предполагает заинтересованности врачей-травматологов в сокращении сроков лечения и количества осложнений.

Развитие государственной экономики в условиях новых рыночных отношений напрямую зависит от здоровья всех слоев населения. Особая роль должна отводиться работоспособному населению. Статистика демографических процессов показывает снижение прироста новых сил в общественное производство. В этих условиях потери рабочего времени в связи с временной или стойкой потерей трудоспособности от травм и заболеваний опорно-двигательного аппарата наносят ощутимый ущерб обществу.

Появление новых технологий, основанных на применении биоактивных интрамедуллярных имплантатов, реально позволяет не только гарантировать положительный результат лечения переломов длинных трубчатых костей, но и осуществлять его в очень короткие сроки за счет стимуляции репаративного остеогенеза и сокращения сроков остеосинтеза. 
Технология лечения переломов защищена патентами РФ (Патент № 2317034 «Способ лечения переломов длинных трубчатых костей»; Патент № 2324450 «Спица для интрамедуллярного армирования длинных трубчатых костей», опубл. 20.05.2008; заявка на патент № 2010145877 «Комплект хирургических инструментов для интрамедуллярного стимулирования остеогенеза трубчатой кости», дата регистрации 10.11.2010, положительное решение от 30.08.2012; Патент №116763 «Интрамедуллярная спица» от 10.06.2012 г.; Патент №130494 «Спица для остеосинтеза» от 27.07.2013 г.; Патент №141821 «Устройство для интрамедуллярного остеосинтеза» от 12.05.2014 г.; Патент №151398 «Интрамедуллярный имплантат» от 3.03.2015г.; Патент №154067 «Устройство для комбинированного остеосинтеза» от $15.07 ю 2015$ г.) и является усовершенствованием прежде всего метода чрескостного остеосинтеза, обеспечивающего возможность закрытой репозиции и надежной фиксации костных фрагментов с помощью АВФ.

Показания к использованию медицинской технологии. Технология показана при лечении больных с закрытыми или открытыми переломами длинных трубчатых костей. В наибольшей степени освоены методики лечения диафизарных переломов (поперечных, косых, винтообразных, оскольчатых).

Остеосинтез осуществляется в ургентных условиях или в плановом порядке.

Противопоказания к использованию медицинской технологии. Абсолютными противопоказаниями к применению технологии являются соматические заболевания, исключающие возможность проведения общего обезболивания или каких-либо оперативных вмешательств, тяжелые психические расстройства. Временными противопоказаниями служат: обширное загрязнение раны при открытом переломе, которое требует ее ПХО и профилактики остеомиелита; инфекционное поражение тканей сегментов конечностей и смежных суставов; острый период остеомиелита.

\section{1. Общие принципы интрамедуллярного остеосинтеза}

Операцию проводят, как правило, при скелетном вытяжении поврежденной конечности. В ближайшем к перелому кости метафизе с помощью специальной фрезы ( рис. 4.1) диаметром 3-5 мм или шила соответствующего диаметра (3-4 мм) в кортикальном слое формируют сообщающиеся с костномозговым каналом наклонные отверстия (по одной с наружной и внутренней поверхности кости). 


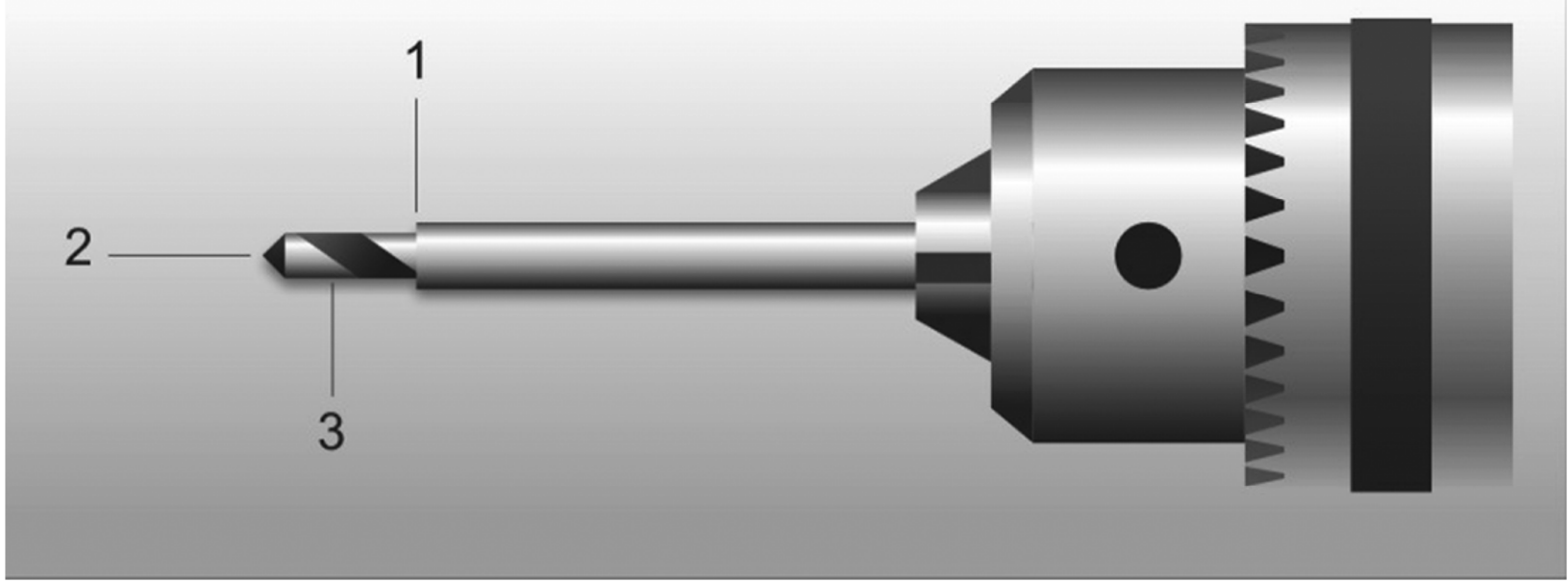

Рис. 4.1. Специальная фреза для формирования канала в кортикальном слое кости: 1 - ограничительная площадка; 2 - режущая поверхность сверла; 3 - режущая поверхность фрезы.

Через эти отверстия проводят две спицы с биоактивным ГА-покрытием. Длина спиц должна соответствовать длине костномозгового канала. Для остеосинтеза перелома нами обычно используются спицы с тупым концом, без заточки.

После того как спица вошла в канал на заданную величину, избыток ее длины скусывают, а конец загибают и погружают под фасцию сегмента конечности. Ввиду того, что при лечении переломов спица не подвергается перемещению, ее конец можно защитить пластиковым грибовидным ограничителем, который занимает место в наклонном отверстии, сформированном в кортикальном слое кости (рис. 4.2).

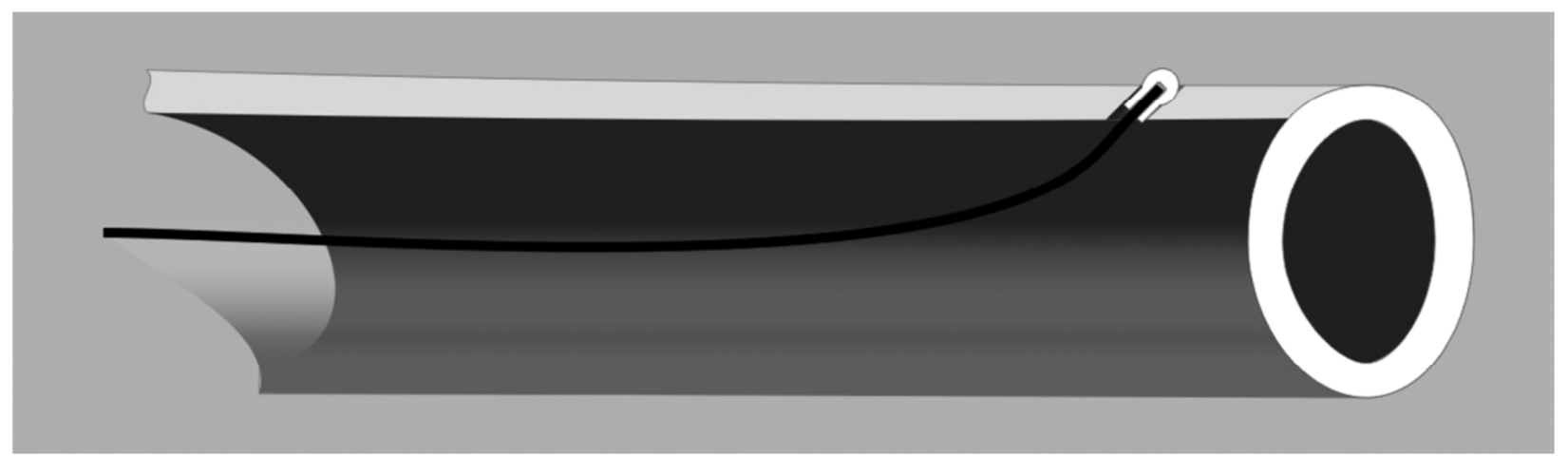

Рис. 4.2. Фиксация интрамедуллярной спицы в костномозговом канале с помощью пластикового ограничителя (схема).

После введения интрамедуллярных спиц мягкие ткани ушивают наглухо и осуществляют чрескостный остеосинтез укороченного сегмента конечности аппаратом Илизарова в той комплектации, которая соответствует поставленной перед хирургом задаче. Окончательная репозиция отломков в аппарате проходит по технологии, неоднократно описанной сотрудниками РНЦ «ВТО» им. акад. Г.А. Илизарова в методических рекомендациях, утвержденных МЗ РФ. Наличие в костномозговом канале спиц с 
биоактивным покрытием не мешает проведению спиц аппарата Илизарова через поперечник кости и репозиции отломков.

Клиническая практика показала, что при интрамедуллярном армировании в ряде случаев можно исключить громоздкие варианты чрескостного остеосинтеза аппаратом Илизарова и заменить их на облегченные спице-стержневые варианты или даже монолатеральные аппараты. Последние создают более комфортные условия для пациента, сохраняют стабильность остеосинтеза без функциональных ограничений. Это важно и с точки зрения снижения травматичности оперативного вмешательства, и облегчения ухода за пациентом при сочетанной или множественной травме.

Принципиально, что введение спиц в костномозговой канал возможно и после осуществления чрескостного остеосинтеза и репозиции отломков аппаратом Илизарова это решает хирург, исходя из конкретной клинической картины и личного опыта.

Использование интрамедуллярных спиц позволяет резко сократить сроки фиксации в аппарате Илизарова - до 15-30 дней. Последующая иммобилизация поврежденного сегмента может быть продолжена современным функциональным ортезом. Возможности функционального ортезирования после демонтажа аппарата исключают развитие вторичных деформаций даже при отсутствии выраженной периостальной реакции в зоне перелома.

Вопрос о сроках удаления спиц решается индивидуально. Титановые спицы не вызывают каких-либо патологических изменений в организме, поэтому могут не удалятся вообще. Если хирург с пациентом предполагают удаление имплантата после консолидации перелома, то эту процедуру желательно осуществить не позднее 3-х месяцев после демонтажа аппарата Илизарова. К этому сроку сращение перелома позволяет пациенту ходить с полной нагрузкой без дополнительных средств опоры. Под местной анестезией или при внутривенном наркозе над местом введения спиц производят разрез кожи (5-8 мм), мягкие ткани тупо раздвигают и, захватив конец спицы крючком или специальными щипцами, вращательно-поступательными движениями извлекают ее из костномозгового канала. В некоторых случаях пациент (по субъективным причинам или в силу каких-либо социальных причин) не приходит вовремя для удаления спиц. В этом случае вокруг спицы формируется мощный костный футляр, связанный с эндостом. При значительном сопротивлении спицы следует воспользоваться дозированным ударным механизмом, который навинчивают на шило-крючок (рис. 4.3). 


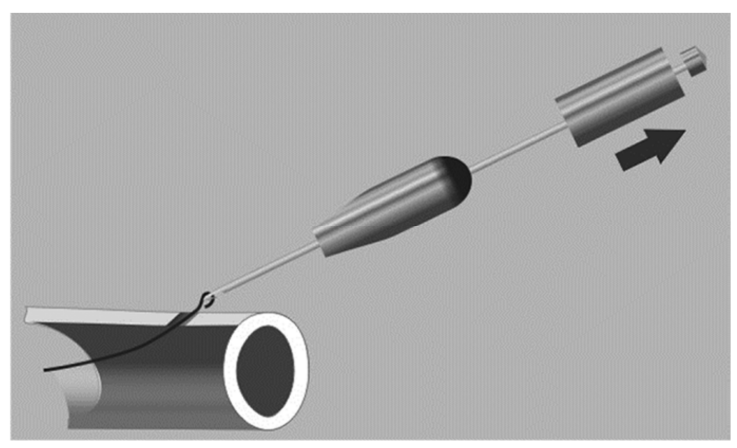

a

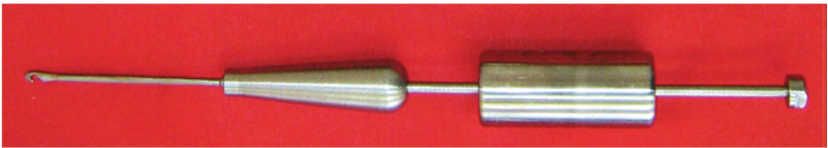

б

Рис. 4.3. Процесс удаления интрамедуллярной спицы: а - шилом-крючком с ударным механизмом (схема); б - внешний вид шила-крючка с ударным механизмом.

Возможные осложнения и способы их устранения. Осложнений, связанных с интрамедуллярным введением спиц, мы не наблюдали. Трудности, возникавшие при удалении интрамедуллярных спиц, назвать осложнениями нельзя ввиду того, что дополнительный специальный инструмент, разработанный нами, позволяет с ними справляться.

Все осложнения, встретившиеся нам в клинической практике, связаны с основным методом чрескостного остеосинтеза отражают особенности того аппарата внешней фиксации, который применяли (аппарат Илизарова).

Наиболее частым осложнением при использовании метода чрескостного остеосинтеза является воспаление мягких тканей вокруг спиц, фиксированных в опорах аппарата. Однако число их резко снизилось (не превышало 10\%) за счет того, что аппарат Илизарова демонтировали уже через 3-4 недели. Причинами данных единичных осложнений стало нарушение асептики или антисептики во время амбулаторного лечения, а так как бо́льшую часть срока остеосинтеза (17-30 дней) больной находится в стационаре, их число сводится к минимуму.

Мы очень осторожно использовали интрамедуллярный имплантат при открытых переломах костей. Вначале это были случаи интрамедуллярного армирования через 7-10 дней после первичной хирургической обработки открытого перелома, затем мы применяли метод непосредственно после ПХО (при отсутствии сомнений в чистоте раны от некротизированных тканей и загрязнений) и под прикрытием антибиотиков. Осложнений ни в одном случае не наблюдали.

Инфицирование тканей или развитие остеомиелита может стать серьезным осложнением открытых переломов. Отсутствие инфекционных осложнений у наших пациентов можно связать с особенностями наноструктурированной поверхности имплантата, однако это предположение необходимо проверить в дальнейших исследованиях. Первые шаги в данном направлении сделаны G. Colon et al. (2006), 
которые установили, что наноструктурированная частицами оксида цинка и диоксида титана поверхность имплантата способствует лучшей адгезии и функциональной активности остеобластов и, напротив, препятствует адгезии патогенных бактерий, таких как Staphylococcus epidermidis

\section{2. Остеосинтез диафизарных переломов бедренной кости}

Диафизарные переломы бедра всегда занимали 2-е место (после голени) по частоте среди всех переломов длинных трубчатых костей, что составляет от 10 до 40 \% [Ткаченко С.С. и др., 1975; Сысенко Ю.М., 2001; Котельников Г.П., Миронов С.П., 2008].

Стандартной практикой лечения диафизарных переломов бедра является интрамедуллярный блокирующий остеосинтез, реже - накостный остеосинтез массивными пластинами с компрессирующими винтами.

Внеочаговый остеосинтез редко применяется при лечении диафизарных переломов бедренной кости вследствие анатомических особенностей строения бедра: длинную кость окружает значительный мягкотканный массив, а нижерасположенный участок конечности является весомым рычагом, что способствует смещению отломков и снижает стабильность фиксации [Ключевский, В.В., 2010; Пичхадзе, И.М., 2006; В.В. Стадников, А.С. Кузнецова, А.П. Барабаш, 2004; В.P. Scannell et al.,2010].

Стандартной практикой лечения диафизарных переломов бедра за рубежом является применение аппаратов внешней фиксации на первой стадии с последующей их заменой на интрамедуллярный остеосинтез через 2 недели. Показания для данного двухэтапного метода остеосинтеза определены, как правило, множественной травмой при состояниях, опасных для жизни, что позволяет контролировать другие травматические повреждения и восстановить общее состояние организма до перехода к внутреннему остеосинтезу. Метод комбинированного чрескостного остеосинтеза применяется и в России со спицестержневыми аппаратами [Л.Н. Соломин, 2005].

Консолидация переломов диафиза бедренной кости независимо от способа лечения, если оно проходило без осложнений, наступает в сроки от 14-18 недель при консервативных методах лечения, а при оперативных методах лечения трудоспособность восстанавливается через 16-20 недель. Так утверждается в Национальном руководстве по травматологии (2008). Однако в многочисленных исследованиях, где состояние вопроса глубоко анализируется с позиций зависимости от тяжести повреждения, возраста пострадавшего, осложнений и других факторов, подчеркивается, что реальные сроки нетрудоспособности составляют 8-10 месяцев,

При неблагоприятном течении процесса консолидации отмечают следующие последствия и осложнения: неправильно сросшиеся переломы со смешением (10-12\%), 
замедленная консолидация и псевдоартрозы (4-5\%), остеомиелит после оперативного вмешательства (3-4\%), контрактуры коленного сустава (до 30\%) [Губко А.А., 1980; Агаджанян В.В., Пак В.П., 1984; Кулик В.И., 1992; Дедушкин В.С., 1999; Бялик Е.И. и др., 2002; Рушай А.К. и др., 2004; Мартель И.И., 2006; Yuan М., 2001; Oksu G., Aktuglu К., 2005].

Метод интрамедуллярного наряженного армирования спицами с биоактивным ГАпокрытием мы используем как существенное дополнение к остеосинтезу бедра аппаратом Илизарова, направленное на стимуляцию репаративного остеогенеза в зоне перелома и увеличение стабильности фиксации костных фрагментов, что позволяет демонтировать аппарат Илизарова уже через 4-6 недель даже при открытом переломе.

Клинический пример. Пациент П., 19 лет. Диагноз: открытый перелом диафиза левого бедра с полным смещением отломков (рис. 4.4 a). Мотоциклетная травма - прямой удар.

Операция: ПХО с удалением некротизированных и загрязненных участков бедренной кости и мягких тканей, открытая репозиция и остеосинтез аппаратом Илизарова с интрамедуллярным армированием спицами с ГА-покрытием (рис. 4.4 б).

Ввиду того, что ПХО раны сопровождалась удалением некротизированных и сильно загрязненных тканей, идеальной репозиции костных отломков осуществить не представлялось возможным. Тем не менее консолидация рентгенологически определялась уже через 4 недели (рис. 4.4 в) - выраженная периостальная реакция. Больной ходил с полной нагрузкой на поврежденную ногу без дополнительных средств опоры еще в течение месяца, наблюдаясь в амбулаторных условиях.

Проведенная клиническая проба на консолидацию кости подтвердила наличие сращения. Аппарат был демонтирован в тот же день без дополнительной иммобилизации (рис. $4.4 \partial, e$ ).

Через 1 год отмечено полное функциональное восстановление (рис. 4.4 ж, з).
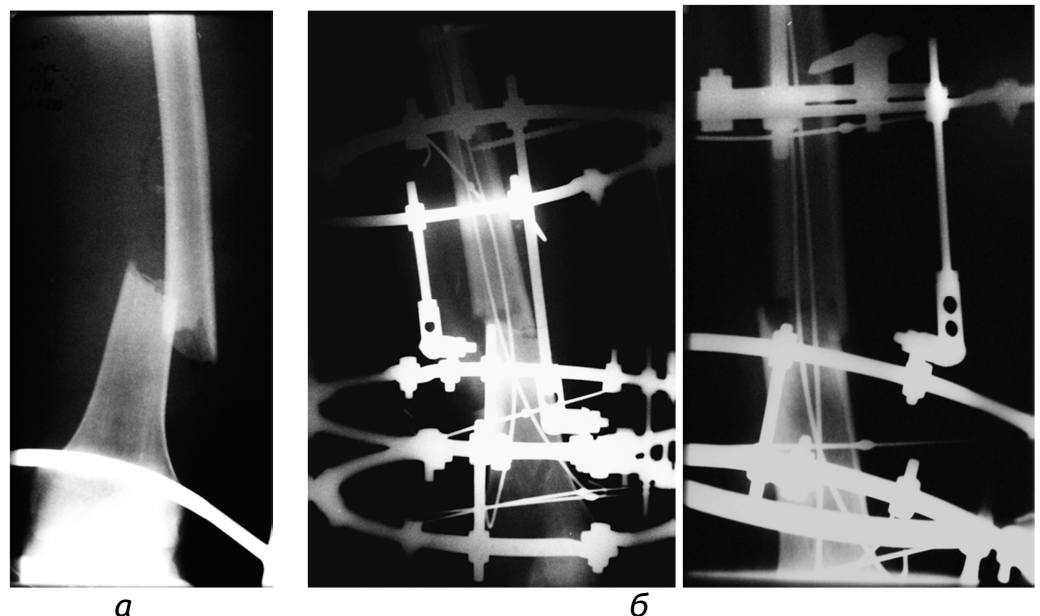


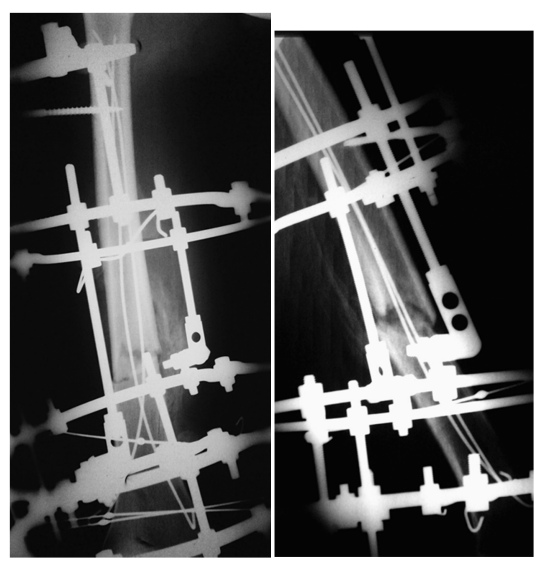

$B$

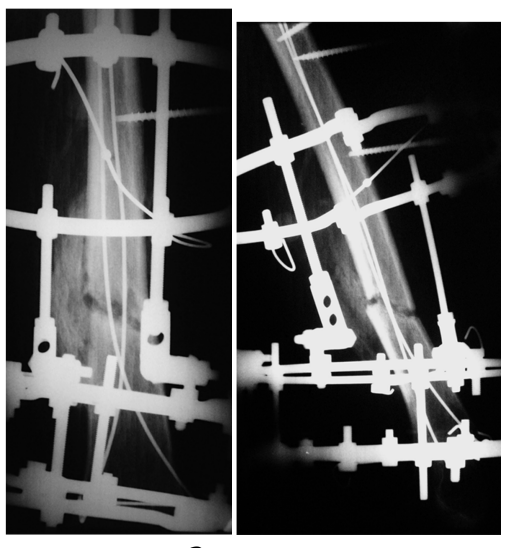

2

Рис. 4.4. Пациент П., 19 лет: а — рентгенограмма бедра в день травмы; б - рентгенограммы бедра в день операции; в - рентгенограммы бедра через 4 недели после операции; г - рентгенограммы бедра через 2 месяца после операции.

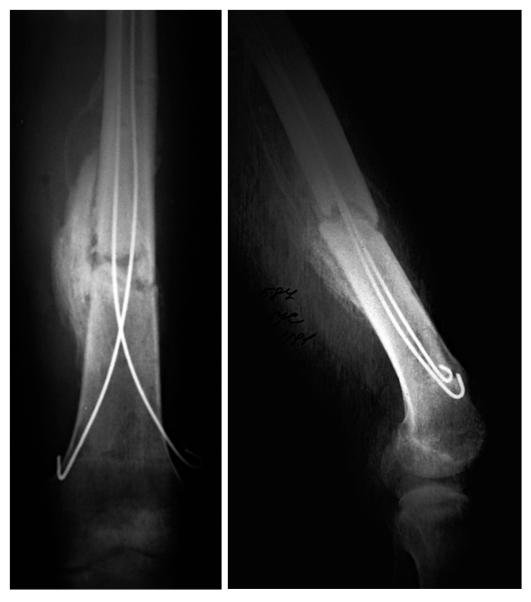

$\partial$

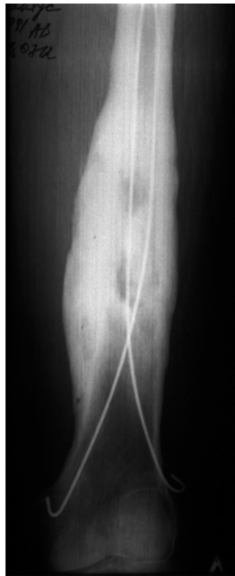

e

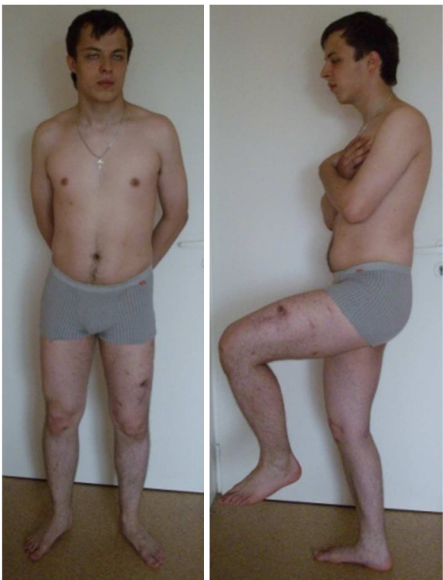

ж

Рис. 4.4. (продолжение). Пациент П., 19 лет: д - рентгенограммы бедра после демонтажа аппарата Илизарова; е - рентгенограмма бедра через 1 год после травмы; ж - внешний вид и функция нижней конечности через 1 год после травмы.

Клинический пример. Пациентка К., 7 лет. Диагноз: закрытый перелом диафиза левого бедра с полным смещением отломков (рис. 4.5 a). Автодорожная травма - прямой «бамперный» удар. Операция: остеосинтез бедренной кости спице-стержневым аппаратом внешней фиксации, интрамедуллярное армирование спицами с ГА-покрытием (рис. 4.5 б).

Рентгенологические проявления процесса репаративной регенерации костной ткани мы начали отмечать через 3 недели после операции в виде незначительной по объему нежной облаковидной тени, расположенной в диастазе между отломками. Эти признаки начала консолидации стали основанием для демонтажа аппарата Илизарова (рис. 4.5 в). Через 1,5 месяца больная ходила с полной нагрузкой и даже приступила к тренировкам по художественной гимнастике.

Через 3 месяца на рентгенограмме видна отчетливая картина эндостального костеобразования, распространяющаяся по костномозговому каналу выше и ниже линии перелома на 1-1,5 см, и периостального костеобразования (рис. 4.5 г). Функция смежных суставов полностью восстановилась (рис. $4.5 \partial$ ). 
Через 6 месяцев (рис. 4.5 e, ж) было констатировано полное функциональное и спортивное восстановление.

В этот же срок интрамедуллярные спицы были удалены.

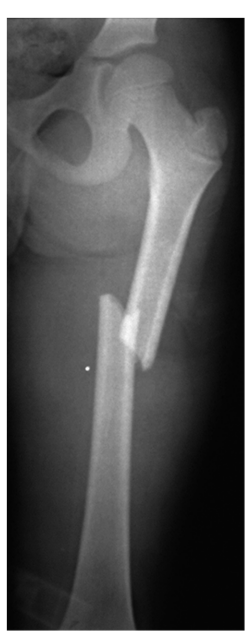

a

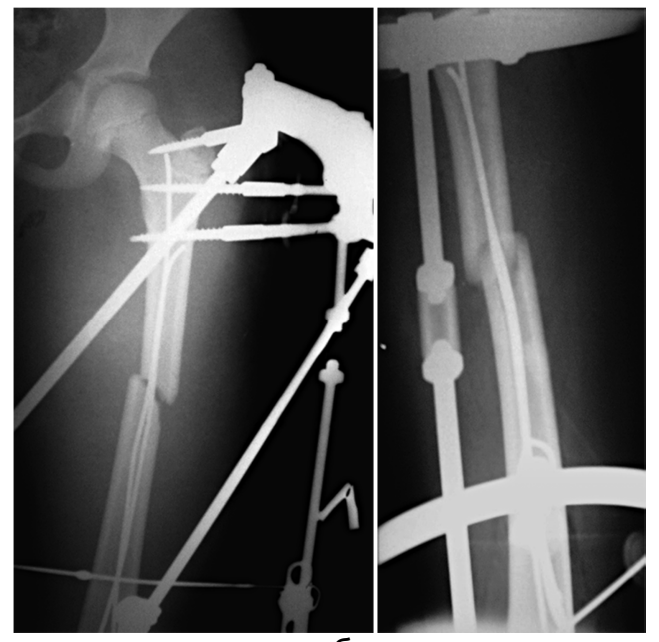

6

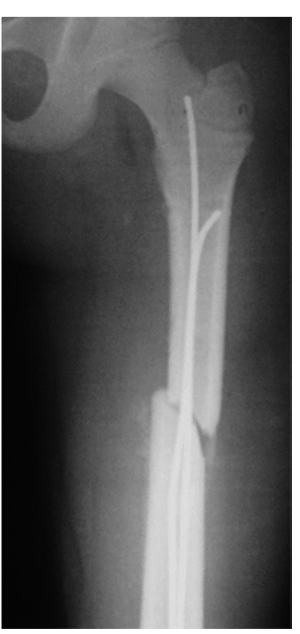

$B$

Рис. 4.5. Пациентка К., 7 лет: $a-$ рентгенограмма бедра до лечения; $\sigma$ - рентгенограммы бедра после операции; в - рентгенограмма бедра после демонтажа аппарата Илизарова (через 21 день после операции).

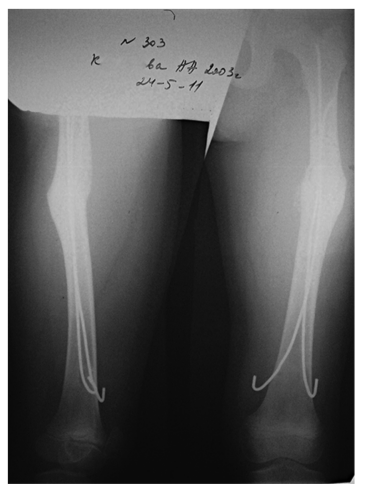

2

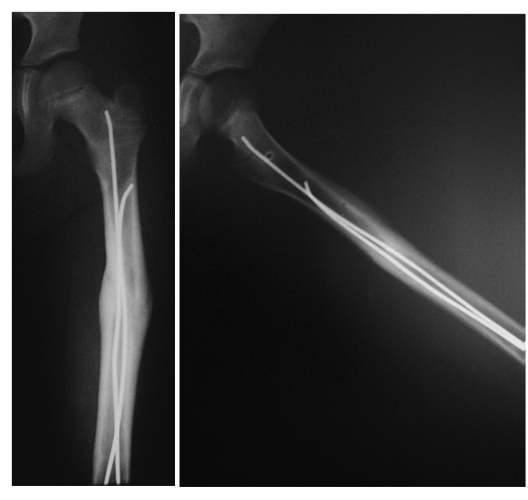

$\partial$
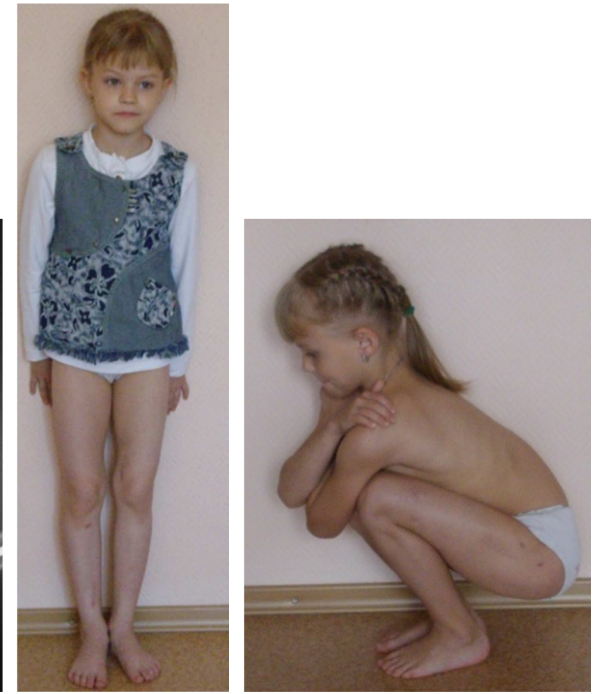

$e$

Рис. 4.5. (продолжение). Пациентка К., 7 лет: г — рентгенограммы бедра через 3 месяца после операции; д - рентгенограммы бедра через 6 месяцев после демонтажа аппарата Илизарова; е - внешний вид и функция нижней конечности через 3 месяца после операции.

Клинический пример. Пациентка Б., 23 лет. Диагноз: Закрытый перелом диафиза левого бедра, полученный в результате ДТП. Операция: Остеосинтез аппаратом Илизарова по классической методике.

После 5 месяцев остеосинтеза диагносцирована замедленная консолидация с признаками формирования ложного сустава. Больная жаловалась на постоянные боли в бедре, которые не позволяли ей продолжить обучение в ВУЗе (она не могла сидеть, долго стоять, посещать лекционные и практические занятия). После клинической пробы на 
консолидацию, которая выявила неограниченную подвижность фрагментов в зоне перелома было решено продолжить лечение методом комбинированного остеосинтеза с интрамедуллярными спицами с ГА покрытием.

При облегченном варианте спице-стержневого аппарата внешней фиксации пациентка начала ходить с полной нагрузкой, свободно продолжила обучение в вузе, а через 1,5 месяца наступила консолидация и аппарат был демонтирован (Рис.4.6 ).

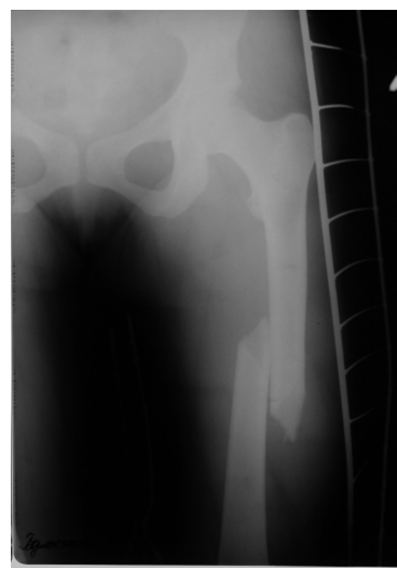

a

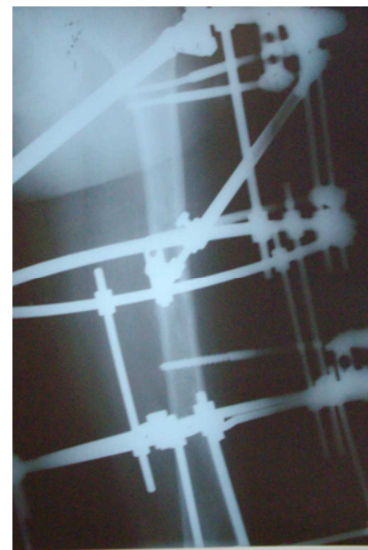

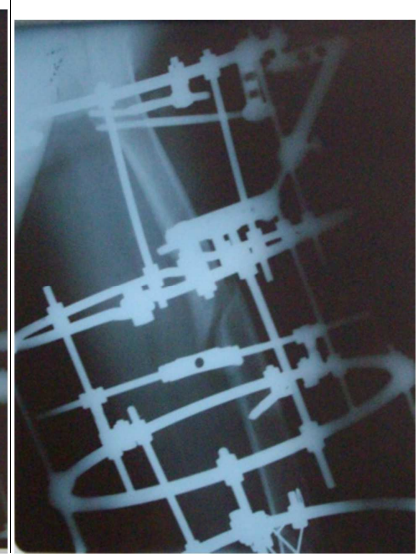

6
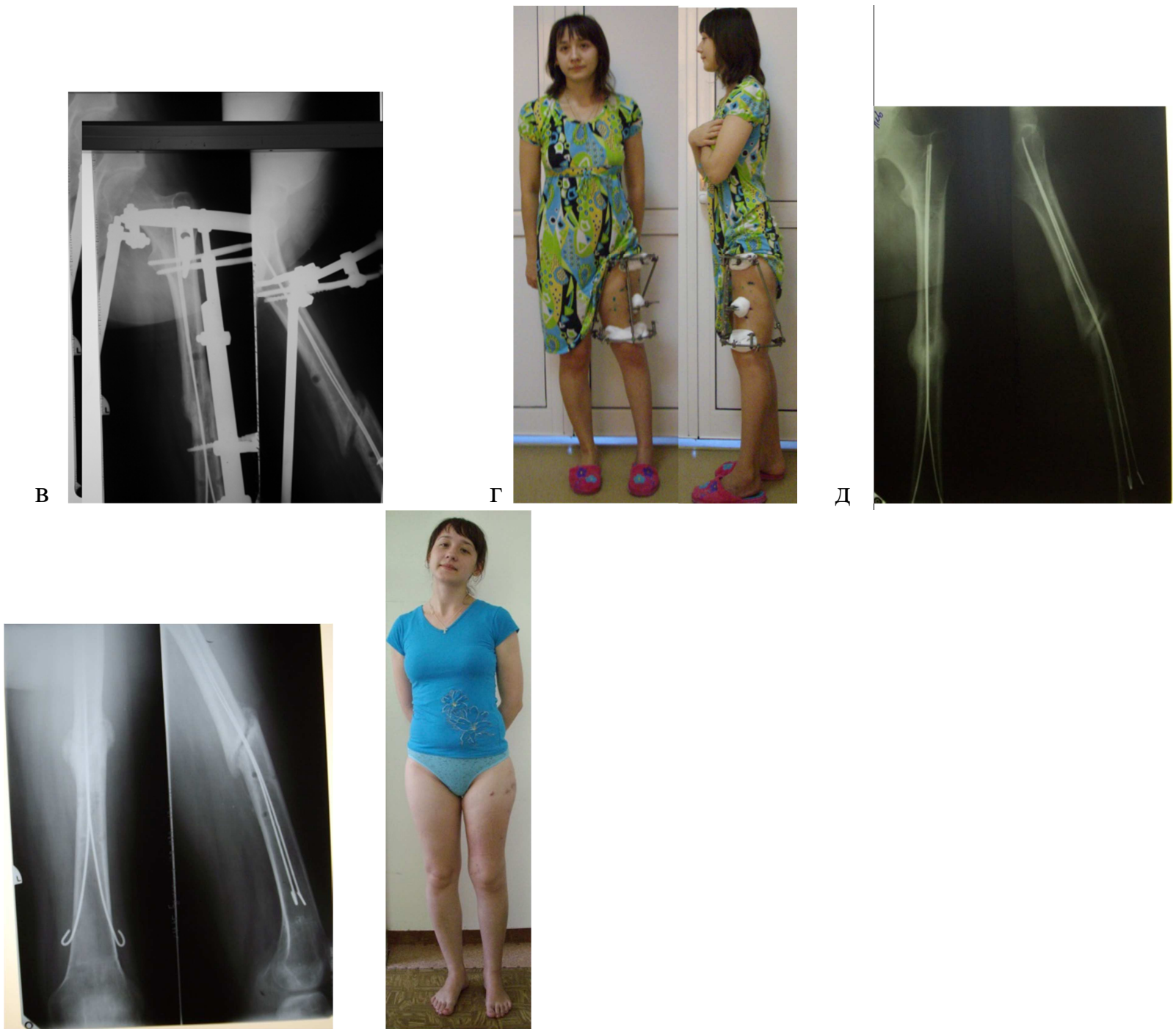

Д

\section{.}


Рис. 4.6. Пациентка Б., 23 лет: $a$ - рентгенограмма бедра после травмы; $\sigma$ - рентгенограммы бедра через 5 мес.после чрескостного остеосинтеза аппаратом Илизарова; 6 - рентгенограмма бедра в день комбинированного остеосинтеза; г - фото пациентки при комбинированном остеосинтезе; д рентгенограммы бедра в день демонтажа АВФ; е - рентгенограммы бедра и фото пациентки через 2 месяца после демонтажа аппарата..

На контрольном осмотре через 2 месяца: пациентка ходит с полной нагрузкой, полностью обслуживает себя и свою семью, успешно(с красным дипломом) закончила Челябинский государственный сельскохозяйственный институт.

\section{3. Остеосинтез переломов шейки бедра и чрезвертельных переломов}

\section{бедренной кости}

Переломы шейки бедра по их анатомической локализации делятся на субкапитальные переломы (линия перелома проходит вблизи головки бедренной кости), трансцервикальные (проходит непосредственно через шейку бедренной кости) и на базисцервикальные (расположена у основания шейки бедра) (рис.4.7).
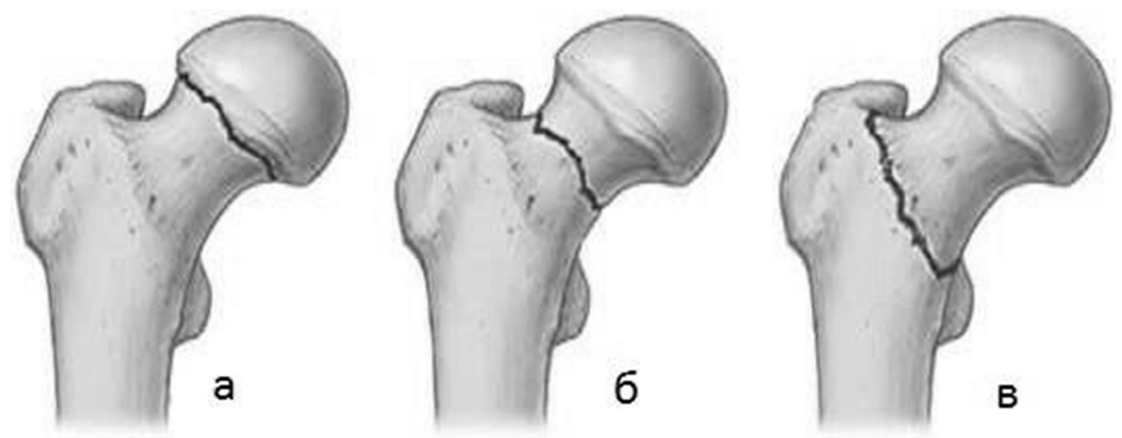

Рис. 4.7. Классификация переломов шейки бедра: а - субкапитальный перелом шейки бедра, б трансцервикальный перелом шейки бедра, в - базисцервикальный перелом шейки бедра.

Субкапитальный перелом самый неблагоприятный в плане прогноза сращения, ввиду трудностей репозиции и фиксации и особенностей кровоснабжения головки. Наиболее благоприятен для сращения перелом в области основания шейки бедра.

Классификация переломов шейки бедра по Pauwels, в основе которой учитывается величина угла, образованного линией перелома с горизонталью [Pauwels F., 1935]. Выделено три типа: Pauwels I - соответствует углу меньше $30^{\circ}$, имеет самую низкую вероятность дислокации (смещения); Pauwels II - угол между линией перелома и горизонталью от $30^{\circ}$ до $70^{\circ}$ имеет высокую вероятность дислокации; Pauwell III - угол в зоне перелома больше $70^{\circ}$ и наблюдается крайне высокая степень смещения отломков. В частности (рис. 4.8), чем более вертикальная линия перелома, тем труднее достичь полной репозиции отломков и стабильной их фиксации. Что касается классификации переломов шейки бедра по P.S. Garden, разработанной в 1964 г., то она в основном учитывает степень нарушения кровоснабжения и смещение отломков при субкапитальных переломах шейки бедренной кости. 


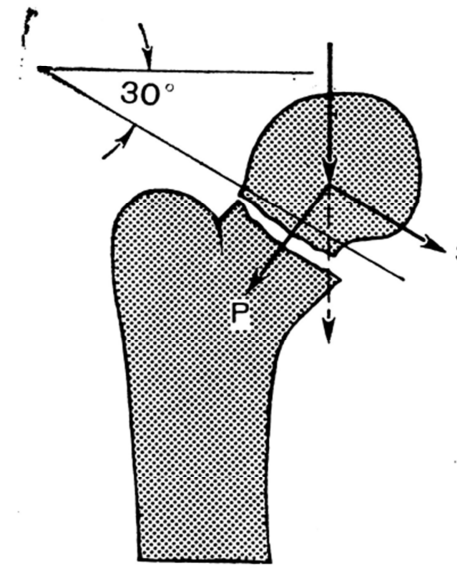

I группа

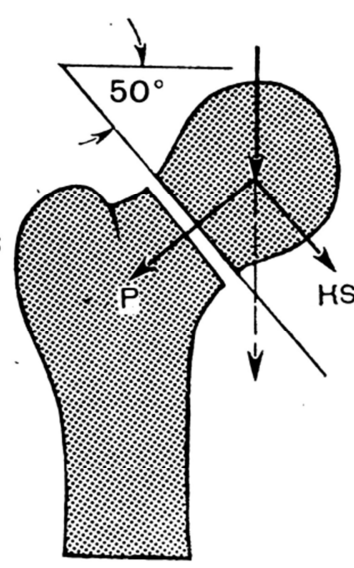

II rpynna

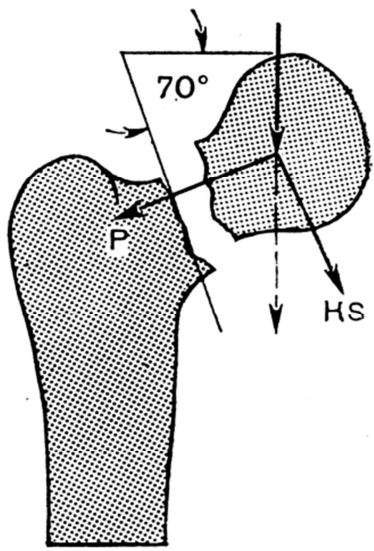

III группа

Рис. 4.8. Тип переломов шейки бедра по Pauwels.

В настоящее время многие клиники используют классификацию переломов АО, (автор М.Е. Мюллер, 1988 г.). Классификация АО излишне детализирует варианты повреждений, она предлагает внутрисуставными переломами считать переломы головки бедра, а переломы шейки бедра считать как внутрикапсульные [М,Е.Мюллер с соавт., 1996].

При всем многообразии предлагаемых классификаций переломов шейки бедренной кости, большинство из них основано на принципе локальности зоны повреждения и выделяют его субкапитальные, трансцервикальные и базальные варианты. Такая градация, наряду с учетом положения отломков - наличия или отсутствия смещения и его вида (варусный или вальгусный перелом) не только влияет на выбор метода лечения и комплекса реабилитационных мероприятий, но и используется в качестве прогностического теста.

Переломы шейки бедренной кости составляют 1,4-6,5\% от всех переломов костей скелета [Войтович А.В. с соавт.,1996], до 70 \% от всех повреждений проксимального отдела бедра [В. А. Копысова и др., 2009; А. С. Сайпиев и др., 2012], и 18,0\% от всех переломов трубчатых костей.

По данным литературы и статистическим отчетам число больных с переломами шейки бедренной кости во всем мире в 1990 г. составляло 1,3 млн. и, согласно прогнозам, в 2025 г. это число удвоится, а к 2050 г. достигнет 4,5-6,3 млн. в год [Ю. В. Акулич, А. Ю. Акулич, А. С. Денисов, 1012; Зоря В.И., Паршиков М.В. ,1996; Krastman P, van den Bent RP, Krijnen P, Schipper IB. ,2006]. В США в год регистрируются 280000 - 300000 переломов шейки бедренной кости [Rogmark C, Carlsson A, Johnell O, Sernbo I. 2002], a 
следующие 40 лет их число вероятно достигнет 5000000 [Kyle RF., 2009], из них 250000 происходит на фоне остеопороза [Марков А. А. с соавт., 2007]. В проспективном исследовании, проведенном в США и охватившем период с 1928 по 1992 годы, отмечено 5-кратное увеличение количества переломов проксимального отдела бедра на 100 тысяч населения. В России частота переломов шейки бедра составляет 100-150 на 100000 населения [Климовицкий В. Г. с соавт., 2008]. Переломы шейки бедренной кости в 95\% случаев возникают при падениях, и чаще всего наступают в результате прямого удара по большому вертелу, когда действующая сила передается с большого вертела на шейку бедра. Проблема переломов шейки бедренной кости рассматривается в медицинском и социальном аспектах главным образом как проблема гериартрическая в связи с развитием иволютивного системного остеопороза [А. С. Сайпиев и др., 2012;Б. М. Хайитбоев, Н. Т. Юсупов, Р. А. Хашимов , 2012; Героева Е. В., 2011; Кульджанов Д. , 2011; А. В. Басов с соавт, 2012; Ломтатидзе Е. Ш. , 2005; А. Л. Матвеев с соавт., 2012; Г.А. Шевалаев с соавт., 2009; Enocson A, Tidermark J, Tornkvist H, Lapidus LJ., 2008; Raaymakers EL, Schafroth M., 2002]. Среди лиц старше 75 лет частота переломов шейки бедра в 4 раза выше. Вместе с тем, производственный и особенно дорожно-транспортный травматизм также приводит к росту числа повреждений шейки бедра у лии молодых и средних возрастных групn [Агаронян Р. Г. , 2010; Fiévez EF et al., 2012; Forsh DA, Ferguson TA., 2012], что приводит также к большим экономическим потерям, связанным с утратой трудоспособности и большими затратами на лечение [Möllenhoff G, et al., 2000]: по литературным данным в Европе и странах Северной Америки стоимость лечения и реабилитации больного с переломом шейки бедренной кости колеблется от 28 до 40 тысяч долларов, а ожидаемые к 2025 и 2050 годам затраты в мире на лечение переломов шейки бедра составят \$82,7 и \$131,5 млрд. соответственно [Р. И. Мельцер и др., 1994; А. Л. Матвеев, 2012].

Среди методов лечения выделяют прежде всего консервативный и оперативный. При консервативном методе лечения летальность достигает 55\% [Филиппенко, В. А. ,1998; Bjørgul K, Reikerås O. , 2007], что связано с декомпенсацией имевшихся на момент травмы сопутствующих заболеваний и тяжелыми осложнениями со стороны сердечно-сосудистой, дыхательной и других систем. Со 2-3 дня постельного режима начинают проявляться симптомы гиподинамии, гипокинезии, нарастают гиповолемия и гипостатические явления в легких. До 33 \% больных умирают в течение первых 6 месяцев после травмы, причем смертность прогрессивно увеличивается с возрастом. 
Большинство специалистов [Мизиев И.А. с соавт., 2013; Ф. М. Усмонов с соавт., 2011; Ролик А.В., Корж Н.А., 1997] считают консервативное лечение переломов шейки бедра неэффективным, не дающим гарантии сращения отломков, способствующим возникновению многих осложнений, связанных с постельным режимом и иммобилизацией: по данным А. Ф. Лазарева и соавт. (2003) при консервативном лечении переломов проксимального отдела бедренной кости у 65 \% больных, несмотря на тщательный уход, возникали пролежни, у $23 \%$ - гипостатическая пневмония. В $18 \%$ случаев на стороне перелома выявляли тромбоз вен нижних конечностей, чаще тромбоз глубоких вен бедра и подвздошной области [Ершова О.Б., Семенова О.В., Дегтярев А.А., 2000].

Таким образом, консервативное лечение пострадавших с переломами шейки бедренной кости нельзя считать оптимальным методом. Большинство современных специалистов указывают, что оно приемлемо лишь в тех случаях, когда имеются серьезные противопоказания к выполнению оперативных вмешательств.

Среди оперативных методов лечения переломов проксимального отдела бедра выделяют погружной остеосинтез, чрескостный остеосинтез, эндопротезирование [И. Ю. Ежов с соавт., 2008; Агаронян Р. Г. 2010].

Выбор метода оперативного вмешательства прежде всего связан с возрастом пациента, наличием серьезных сопутствующих заболеваний, анатомическим и морфологическим состоянием кости.

Учитывая, что большинство пациентов с переломами проксимального отдела бедренной кости - это люди пожилого возраста, обычно с букетом различных хронических заболеваний внутренних органов, выбор метода лечения хирурги и анестезиологи стараются ограничить малотравматичностью оперативного вмешательства.

Несмотря на то, что эндопротезирование тазобедренного сустава все шире применяется при переломах шейки бедра панацеей данную операцию не назовешь: по данным зарубежных авторов [Zhou J et al., 2011; Lavernia, C. Et al., 2004; N.Q. Khan, S.T. Woolson, 1998; K. Bozic, H. E. Rubash, 2004] после операции тотального эндопротезирования у пациентов болевой синдром тазобедренного сустава сохраняется в 17-20\% случаев, и у 32-35 \% отмечаются новые ощущения (от слабо выраженного болевого синдрома или дискомфорта в области тазобедренного сустава до выраженных болей). Первичное эндопротезирование достаточно травматичное вмешательство и сопровождается обильной кровопотерей. В послеоперационном периоде после эндопротезирования возможны следующие осложнения: нагноение, остеомиелит, вывих головки протеза, гетеротопическая оссификация, перелом проксимального отдела бедра, 
риск развития тромботических и тромбоэмболических осложнений. Многие авторы считают подобные операции должны быть ограничены строгими показаниями [В. М. Лирцман, В. И. Зоря, С. Ф. Гнетецкий, 1997; Schmidt AH et al., 2005; Iorio R et al., 2004; Minato I. 2011].

Остеосинтез по-прежнему является основным хирургическим методом лечения переломов шейки бедренной кости. По механизму фиксации отломков все эти устройства можно подразделить на четыре основных группы: устройства, удерживающие костные отломки; создающие компрессирующее усилие; имеющие диафизарно-вертельное основание; и, наконец, фиксаторы, обладающие биологической активностью в отношении репаративной регенерации кости.

Широко применяется как в нашей стране, так и за рубежом остеосинтез шейки бедра винтами DHS с осевым каналом и резьбой для губчатой кости [Ч. Н. Изабеков, В. В. Красоцкий, 2007; Анкин Н. Л.,1997]. По литературным данным использование конструкций DHS приводило к рассасыванию шейки, перфорации головки бедра, миграциям и фрактурам металлоконструкции [Кавалерский Г.М. с соавт., 2005]. При применении DHS по данным некоторых авторов [Мурзабеков И. А. , 2006; Ateschrang A, Dittel KK. , 2007; Itadera E et al., 2003; Lykke N et al., 2003; Skála-Rosenbaum J et al., 2005; Windolf M. Et al., 2009] неудовлетворительный результат отмечен в 13,6 - 31\% случаях.

В настоящее время основными средствами остеосинтеза при переломах шейки бедра являются канюлированные спонгиозные винты системы AO/ASIF, вводимые в шейку бедра в количестве 2-3 штук [Ю. В. Акулич, А. Ю. Акулич, А. С. Денисов, 2012]. Остеосинтез винтами является относительно нетравматичным, незначительно нарушает кровообращение головки и технически доступным для широкого использования. Однако в литературе нет единого мнения относительно количество вводимых винтов в головку бедра, а также их расположения в шейке и головке бедренной кости, а неудовлетворительные результаты лечения составляют 19\%-65\% случаев [Мурзабеков И. А. , 2006; Мизиев И.А. с соавт., 2013].

При использовании винтов возможны следующие осложнения: несращения переломов - 5,6\%-19,4\%, асептический некроз - 11,3\%-33,0\%, поверхностная раневая инфекция 2,6\%, неправильная консолидация перелома - 1,3\%, миграция металлоконструкции 10,5\%, посттравматический деформирующий коксартроз - 10,5\%, а летальный исход составляет от $1,9 \%$ до $22,7 \%$.

Принципиальное противоречие остеосинтезов различными внутренними конструкциями заключается в том, что небольшие конструкции не обеспечивают стабильной фиксации, а большие - разрушают костные фрагменты и их кровоснабжение. 
Кроме того, для любого вида остеосинтеза перелома шейки бедра важен временн'ой фактор начала оперативного вмешательства: профилактикой несрашений, асептичекого некроза головки бедренной кости является остеосинтез в течение первых 24 часов с момента получения травмы [Sokół G, Snela S, Piasek R., 2010; Butt MF et al., 2008; Heikkinen $\mathrm{T}$ et al., 2002], обеспечение полной репозиции и стабильной фиксации костных отломков [Raaymakers EL ,2006; Dhammi IK, Singh S, Jain AK. ,2005; Heikkinen T et al., 2002; Smektala R, Wenning M, Ekkernkamp A. 2001]. Так, по данным F. C Seyfettinoğlu et al. (2011) у больных, у которых остеосинтез был выполнен в течение 24 часов после получения травмы, асептический некроз составил 9,5 \%, тогда как при более позднем остеосинтезе асептический некроз головки бедра отмечен у $40 \%$ пациентов.

Область тазобедренного сустава и шейка бедренной кости имеют особые анатомофизиологические условия, суставная часть проксимального конца бедренной кости у взрослых недостаточно кровоснабжается, так как сосуды связки, питающие головку, облитерируются и кровоснабжение осуществляется только за счет сосудов вертельной области. Шейка бедренной кости не имеет надкостницы, но покрыта сновиальной оболочкой суставной капсулы. Сращение отломков при медиальных переломах шейки происходит только за счет эндостального костеобразования и, следовательно, возможно при идеальной репозиции, плотном контакте между отломками и абсолютной неподвижности в области перелома.

В Курганском НИИ экспериментальной и клинической ортопедии и травматологии под руководством Г.А. Илизарова был разработан и успешно применяется метод чрескостного остеосинтеза переломов шейки бедренной кости (А.c.1050689 СССР /Г.А. Илизаров, В.М. Шигарев, С.Б. 1983; А.с. 1074577 СССР, /Г.А. Илизаров, В.М. Шигарев, С.Б. Либерман, С.И. Швед.1982). Установлено, что применения чрескостного остеосинтеза при переломах шейки бедренной кости является менее травматичным по сравнению с другими методами, что в большинстве случаев позволяет производить остеосинтез по срочным показаниям[Шигарев В.М.,1988; 1993]. Операция остеосинтеза проводится на ортопедическом столе. С помощью скелетного вытяжения за мыщелки поврежденного бедра осуществляется репозиция отломков.

В случае же, когда не удается точно сопоставить костные отломки, применяют следующую методику: через головку бедра на расстоянии 1-1,5 см кнаружи от бедренной артерии проводят одну спицу с упорной площадкой спереди назад и снутри кнаружи, затем через среднюю треть диафиза бедренной кости проводят другую спицу под углом к сагиттальной плоскости. Концы верхней спицы крепят к дуге, а нижней - к кольцу. Между дугой и кольцом устанавливают дополнительную дугу. Обе дуги и кольцо 
соединяют между собой резьбовыми стержнями, которыми осуществляют дистракцию до полного устранения смещения отломков по длине (рис 4.9a).

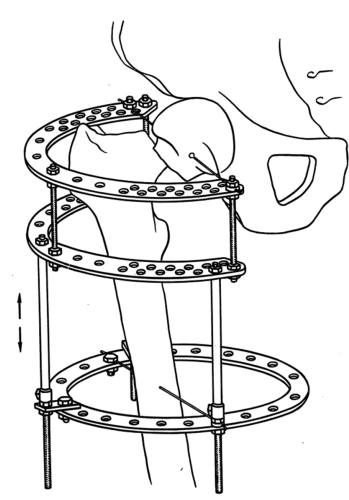

a

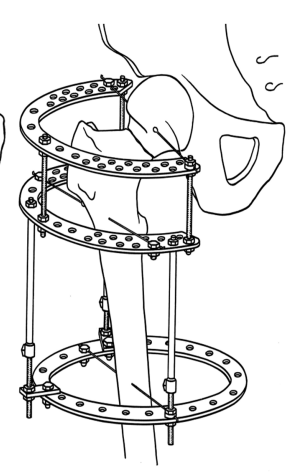

6

Рис. 4.9. Схема наложения аппарата для устранения смещения отломков по длине (а) и смещения костных отломков по ширине (б).

После этого на уровне малого вертела проводят еще одну спицу под углом 30 к сагиттальной плоскости с напайкой сзади (рис 4.9б). При помощи этой спицы устраняется оставшееся смещение отломков по ширине.

Чрескостный остеосинтез сломанной шейки бедренной кости начинается с проведения спиц в шейку и головку бедра. Для этого из подвертельной области, отступая от верхушки большого вертела на 80-90 мм, по наружнобоковой поверхности бедра вводится спица, в направлении верхнего полюса головки, вторая спица вводится в той же плоскости, отступая от верхушки большого вертела на 45-50 мм в направлении нижнего полюса головки. Образуется перекрест во фронтальной плоскости.

C передненаружной поверхности бедренной кости на расстоянии 55-65 мм от верхушки вертела проводится третья спица в направлении задней поверхности головки бедра, и с задненаружной поверхности на этом же уровне проводится четвертая спица к передней поверхности головки бедра. Вторая пара спиц образует перекрест близко к сагиттальной плоскости.

Все спицы проводятся через плотные участки шейки и входят в головку бедра, до субхондрального слоя. При субкапитальных и оскольчатых переломах количество фиксирующих спиц может быть увеличено. Введение и расположение всех фиксирующих спиц контролируется рентгенологически под электронно-оптическим преобразователем (рис. 4.10). 


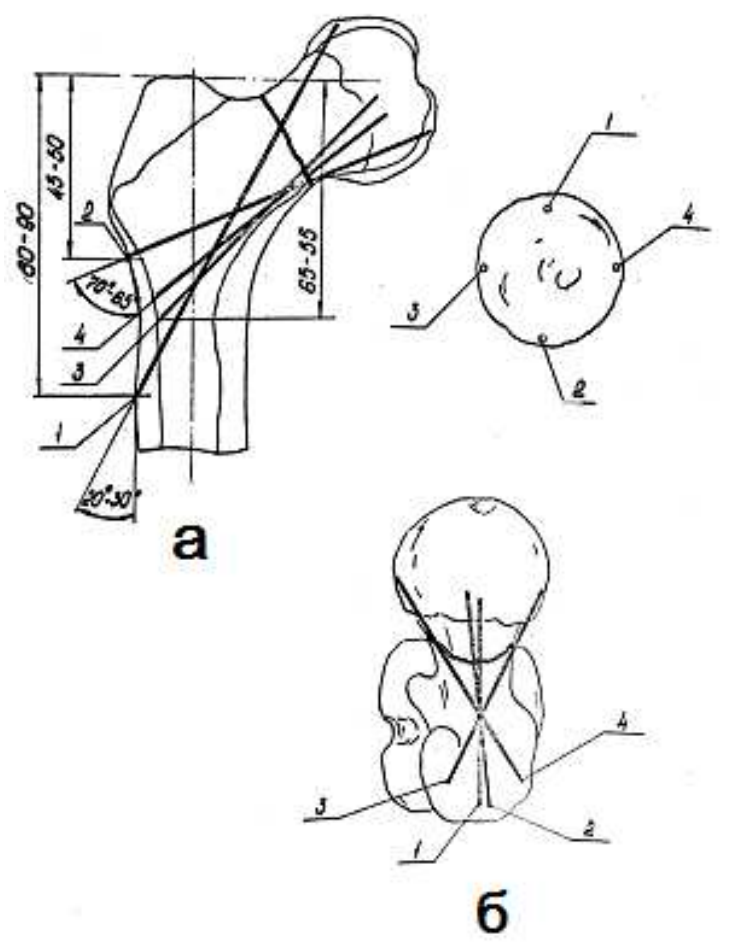

Рис. 4.10. Схема проведения спиц и их расположение в шейке бедра: а) в прямой проекции; б) в боковой проекции.

Затем на уровне средней трети бедренной кости проводятся перекрещивающиеся спицы. Они укрепляются и натягиваются на внешней опоре. В зависимости от характера и локализации перелома, возраста и общего состояния больного из стандартного набора деталей аппарата Илизарова, серийно выпускаемого промышленностью, подбираются детали, позволяющие компоновать соответствующие варианты внешних опор.

Наиболее часто комплектация аппарата представлена в виде кольцевой опоры с кронштейнами, куда крепятся дистрактор с диафиксирующими спицами, проведенными через шейку бедра (рис. 4.11a). У больных повышенного питания аппарат комплектуется из дуги и кольца (рис. 4.11б).

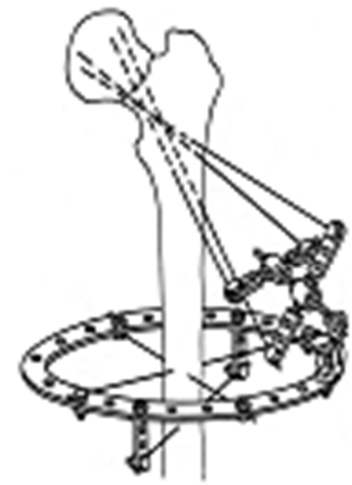

a

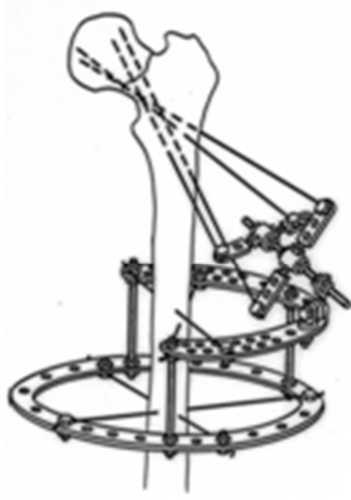

6

Рис. 4.11. Компоновки аппарата из одного кольца и кронштейнов (а) и из кольца и дуги (б). 
Предлагаемый способ проведения и крепления фиксирующих спиц, а также тяги их единым блоком путем перемещения дистрактора относительно фиксатора позволяет при минимальной травме костной ткани добиться стабильной фиксации отломков с возможностью дозированной компрессии между ними (величина компрессирующего усилия принципиально определена в главе 3 во время эксперимента при отрыве спиц из костномозгового канала).

Клиническое наблюдение. Больной Г.,28 лет, водитель. Получил бытовую травму, упал с высоты 10 метров. В течение 13 дней проводилось консервативное лечение (скелетное вытяжение) в условиях городской больницы. Диагноз при поступлении в клинику РНЦ «ВТО» им. академика Г.А.Илизарова: несвежий трансцервикальный, оскольчатый перелом шейки правой бедренной кости. (рис. 10). Операция осуществлена под эпидуральной анестезией - произведен чрескостный остеосинтез перелома шейки бедра. (рис. 11). На следующий день больной начал вставать и ходить с помощью костылей, а через 32 дня больной ходил с опорой на одну трость. (рис. 12). Аппарат снят через 84 дня после остеосинтеза. (рис. 13). Через 5 месяцев после снятия аппарата пациент приступил к работе. Через 13 месяцев после полученной травмы продолжает работать по специальности, жалоб нет, ходит без вспомогательных средств опоры. Наступило полное анатомо-функциональное восстановление (рис. 14,15$)$.

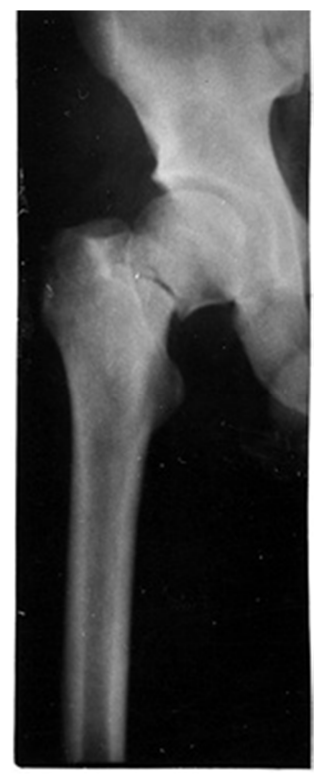

a
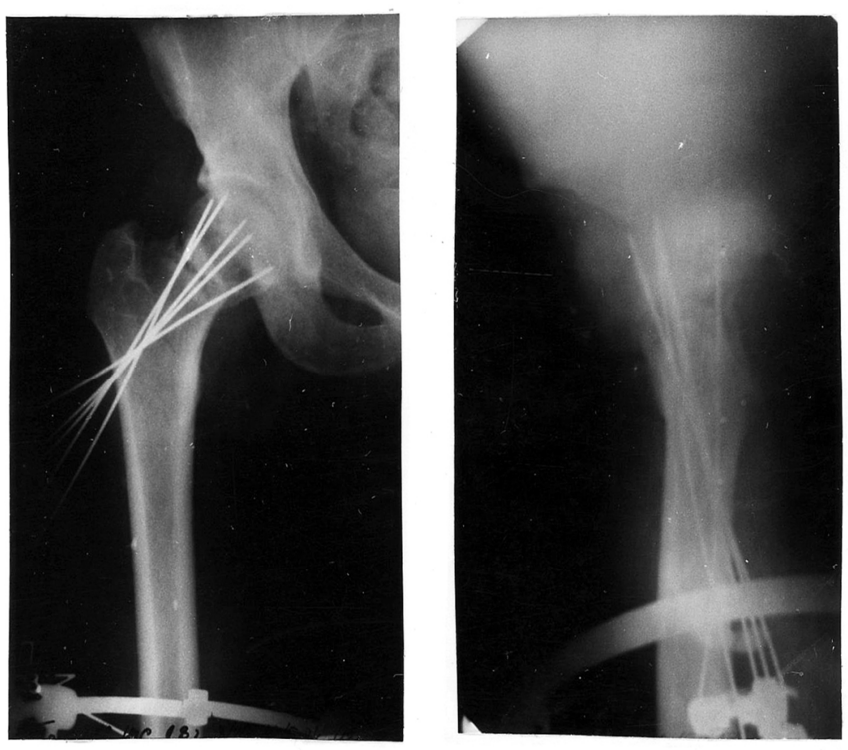

6 


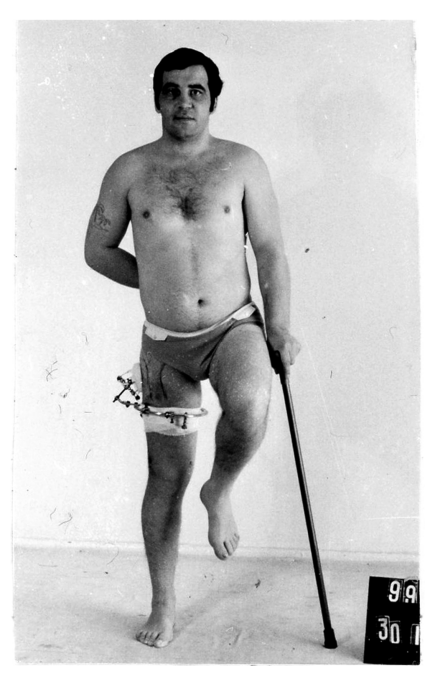

B

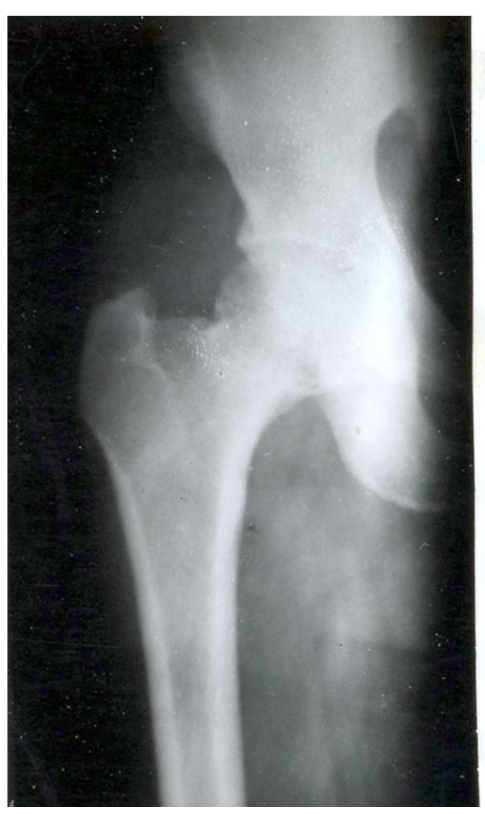

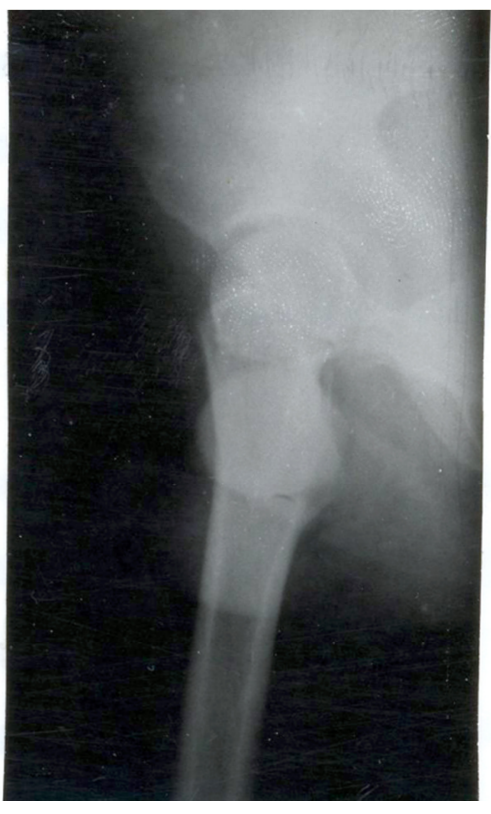

$\Gamma$

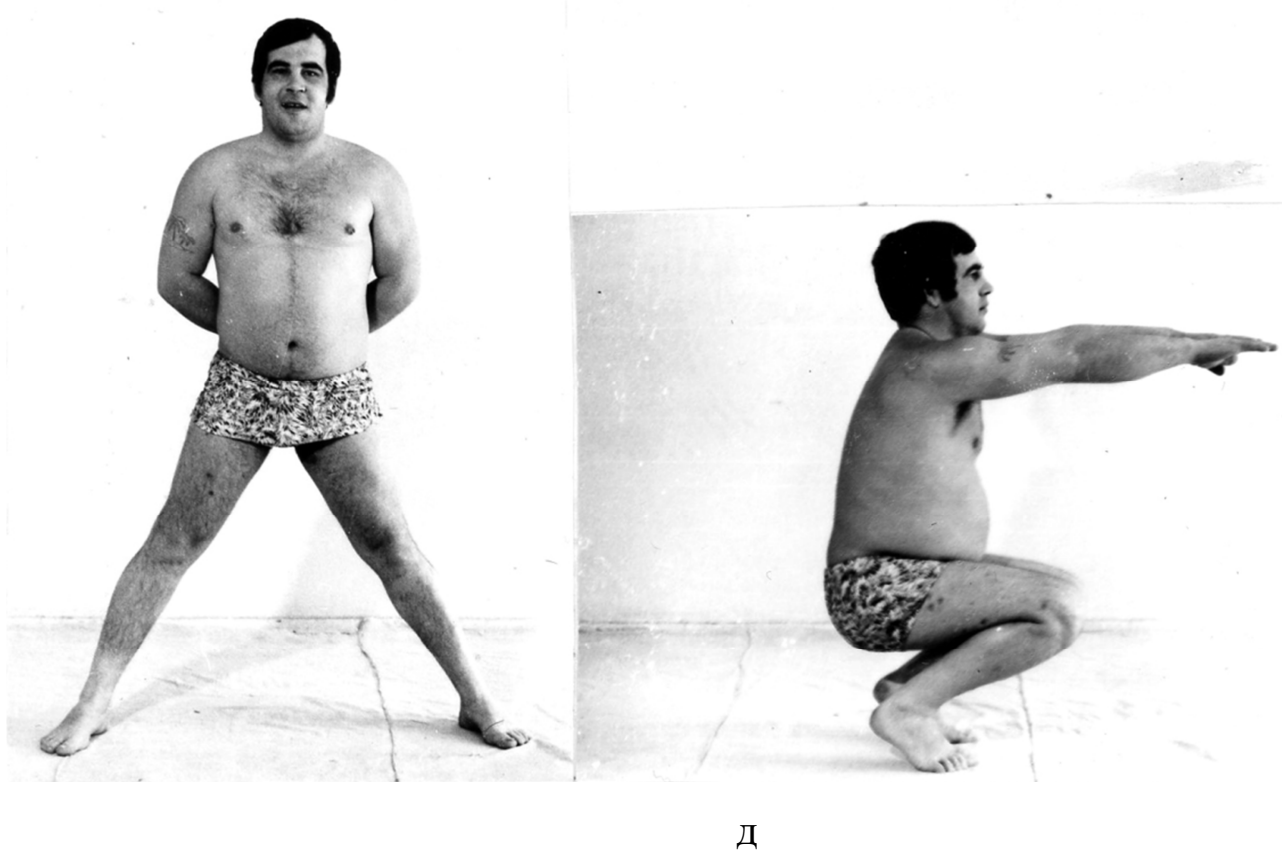

Рис. 4.12. Пациент Г., 28 лет: а - рентгенограммы больного при поступлении; б - рентгенограммы бедра после остеосинтеза шейки спицами; в - фото пациента через 32 дня после операции; г рентгенограммы бедра через 1 год 1 месяц после травмы; д - функция тазобедренного сустава через год после демонтажа аппарата.

\section{Остеосинтез чрезвертельных переломов бедренной кости. Актуальность} проблемы лечения чрез- и межвертельных переломов бедра связана не только с частотой встречаемости (до 52\% от всех видов перелома бедра), но также с социальным положением пострадавших - преобладающее большинство наблюдается у людей пожилого и старческого возраста, 95 \% из которых имеют различной степени выраженности сопутствующие заболевания [Лазарев А.Ф. и др., 2004]. В последние годы для 
остеосинтеза чрез- и межвертельных, а также базисцервикадьных переломов шейки бедра рекомендуют пластины с динамическими (скользящими) винтами или остеосинтез блокированным Ү-гвоздем [Анкин Л.Н., Анкин Н.Л., 2005; Ушаков С.А., 2009].

Несмотря на то, что авторы предложения остеосинтеза Y-гвоздем (Grosse, Tagelung) считают его революционным, этот метод лечения отличается значительной травматичностью оперативного вмешательства (разрез кожи до 8 см, рассверливание костномозгового канала, установка 2-3-х блокирующих винтов), кроме того, длительное время пациент ходит без нагрузки, с костылями, и консолидация наступает через 6-8 месяцев [Ушаков С.А., 2009].

После интрамедуллярного остеосинтеза вертельных переломов бедренной кости интраоперационные осложнения составляют от 12 до 23,4 \% [Fogagnolo F. et al., 2004; Pavelka T. et al., 2005; Saarenpää I. et al., 2006].

Востребованность предлагаемого нами нового метода в значительной степени обусловлена не только его высокой результативностью, обеспечивающей практически в $100 \%$ случаев достижение положительных исходов лечения, но и малой травматичностью оперативного вмешательства, возможностью самообслуживания и амбулаторного лечения пациентов, незначительным сроком остеосинтеза для консолидации перелома и отсутствием необходимости повторной операции для удаления конструкций. Кроме быстрой консолидации перелома, подтвержденной рентгенографией и компьютерной томографией бедра, остеоиндуктивное покрытие стержней-шурупов обеспечивает ремоделирование костной ткани шейки бедра и проксимального метафиза, успешно восстанавливая минеральную насыщенность в зоне проксимального отдела, что предотвращает повторные патологические переломы.

Данная технология лечения пострадавших с чрезвертельными переломами бедра предусматривает фиксацию пораженного сегмента стержневым аппаратом чрескостного остеосинтеза, введение через шейку бедра стержней-шурупов, имеющих специальное кальций-фосфатное покрытие, последующую стабильную фиксацию поврежденного сегмента до консолидации кости. Внутрикостные имплантаты с кальций-фосфатным покрытием обеспечивают стимуляцию регенеративного процесса на протяжении всего периода остеосинтеза сегментов конечностей, что значительно снижает продолжительность лечения.

Технология защищена Патентом РФ № 94444 «Фиксатор для остеосинтеза переломов проксимального отдела бедренной кости», приоритет от 31.12.2009, опубл. 27.05.2010 (М.Ю. Ключников, А.В. Попков, А.В. Карлов). 
Технология показана при лечении больных с чрезвертельными, межвертельными, подвертельными переломами бедра. По классификации Muller - это A1-3, B1-2. Остеосинтез по данной технологии производят по неотложным показаниям или в плановом порядке.

Абсолютными противопоказаниями к применению данной технологии лечения являются субкапитальные переломы шейки бедра со смещением, переломы головки бедра. Временными противопоказаниями служат инфекционное поражение тканей конечности, остеомиелит.

Для осуществления технологии лечения больных с переломом или укорочением конечности используют аппарат внешней фиксации («Инструменты и приспособления для остеосинтеза по Г.А. Илизарову»), зарегистрированный в Государственном реестре медицинских изделий (набор выпускается ФГУП «Опытный завод РНЦ «ВТО» им. акад. Г.А. Илизарова» Росздрава; 640014, г. Курган, ул. М. Ульяновой, 6), а также интрамедуллярные имплантаты с кальций-фосфатным покрытием

Описание медищинской технологии. Положение больного на операционном столе на спине. После анестезии и обработки операционного поля репозицию перелома производят за счет тяги конечности по длине, ее отведения и внутренней ротации в пределах $10-15^{\circ}$. Перелом временно фиксируют спицами, которые также являются ориентиром для правильного введения стержней-шурупов. По наружной поверхности бедра, на 2,5 см ниже ската большого вертела, через прокол кожи в латеральном кортикальном слое кости рассверливают канал с помощью 2-миллиметрового сверла. Через канал, ориентируясь на положение диафиксирующих спиц, вкручивают стержень-фиксатор через шейку до субхондральной зоны головки бедра.

Фиксатор (рис. 4.13) имеет три резьбовых участка, разделенных гладкой поверхностью: центральная резьбовая часть, располагающаяся в головке бедра; средняя резьбовая часть, располагающаяся в костном веществе вертельной области; периферическая резьбовая часть, с помощью которой фиксатор крепится на внешних опорах аппарата Илизарова. За счет разноразмерной и разношаговой резьбы (центральной и средней части) создается межфрагментарная компрессия.

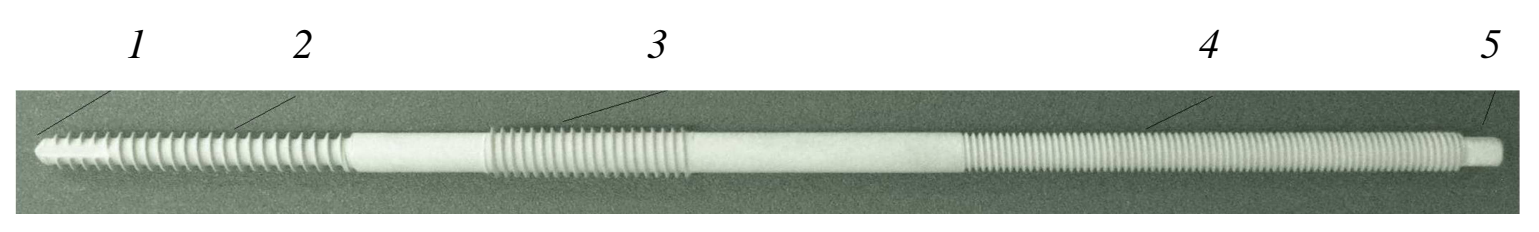

Рис. 4.13. Стержень-фиксатор: 1 - конический самонарезающий конец; 2 - центральная резьбовая часть, переходящая в гладкую поверхность; 3 - средняя резьбовая часть, переходящая в гладкую 
поверхность; 4 - периферическая резьбовая часть; 5 - хвостовик квадратного сечения под установочный ключ.

Для обеспечения стабильного остеосинтеза рекомендуется вводить два фиксатора, располагая их ближе к верхней и нижней внутренним поверхностям шейки бедра (рис. 4.14 и 4.15$)$.

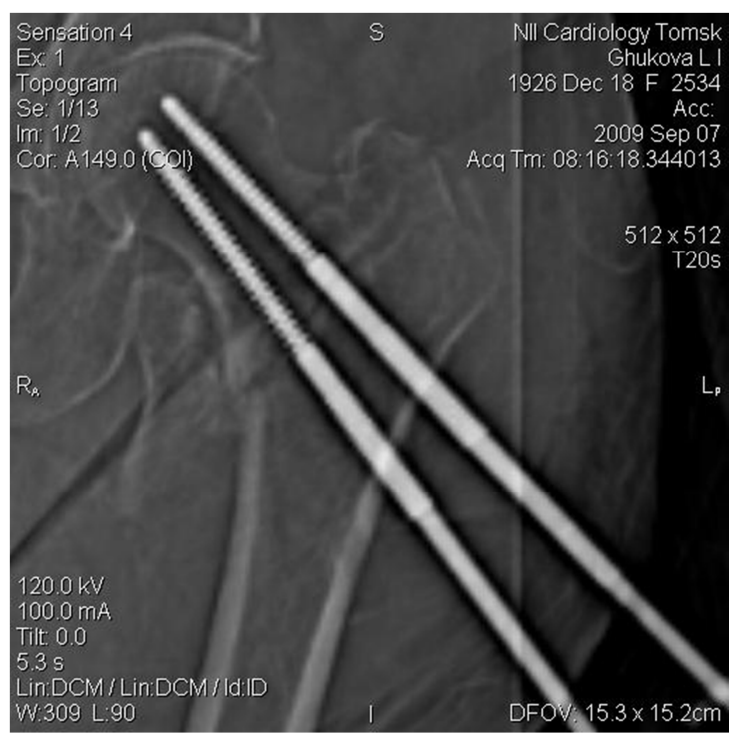

Рис. 4.14. Рентгенограмма тазобедренного сустава, отражающая положение фиксаторов в шейке бедра.

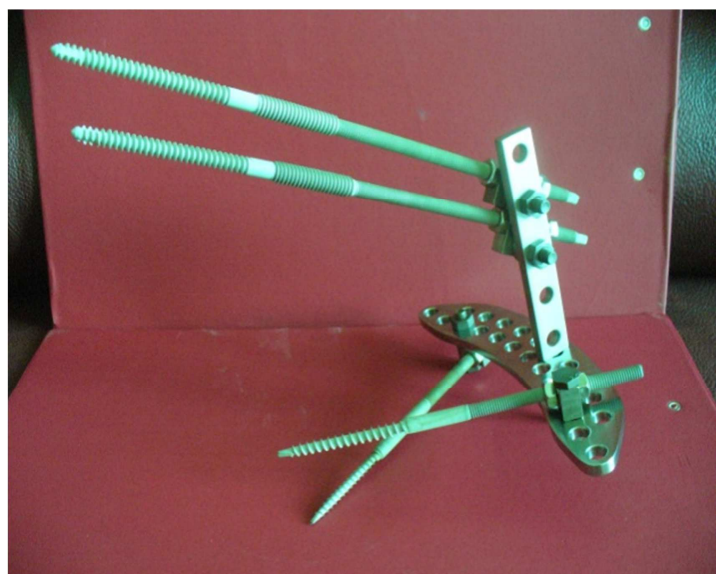

$a$

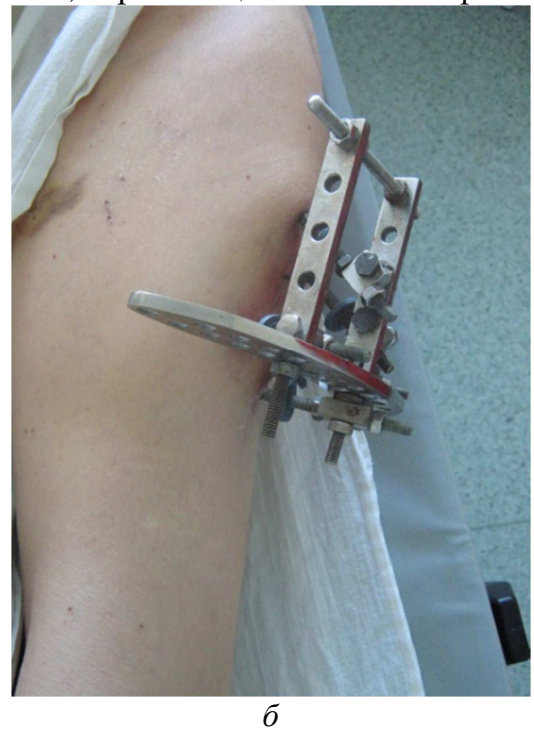

Рис. 4.15. Стержневой аппарат для фиксации чрезвертельных переломов: а — в сборе; б - расположение стержневого аппарата при остеосинтезе бедра.

Клинический пример. Пациентка Ж., 82 лет. Диагноз: закрытый оскольчатый чрезвертельный перелом левого бедра со смещением, остеопороз (рис.4.16 a).

Операция: закрытая репозиция, чрескостный компрессионный остеосинтез стержневым аппаратом внешней фиксации (рис. 4.16 б).

Со 2-го дня после операции больная активно двигалась в кровати. Через 2 недели уверенно себя чувствовала во время ходьбы и на занятиях ЛФК (рис. 4.16 в). 
Через 1,5 месяца после операции у лечащих врачей и у самой пациентки создалось впечатление о полной консолидации перелома (больная полностью себя обслуживала, движения в суставе не были ограничены и не причиняли болей, нагрузка на оперированную ногу подчас была полной, благо, вес больной был небольшим). Однако, учитывая, что это была первая пациентка, оперированная по данной технологии, мы через 46 дней фиксации ограничились демонтажем только части аппарата, сохранив оба стержня, фиксирующих шейку бедра. Окончательно их удалили на 59-й день после операции (рис. $4.162, \partial)$.

Рентгенологический контроль и компьютерная томография подтвердили наличие консолидации костных фрагментов (рис. 4.16 е). Больная выписана на амбулаторное лечение.

Контрольный осмотр через 3 и 5 месяцев показал полную функциональную реабилитацию пациентки (рис. 4.16 ж).

Анализ рентгенограмм в динамике показал значимое увеличение минеральной насыщенности головки и шейки бедра - на срезах головки бедра отчетливо видны плотные трабекулы (рис. 4.16 з) радиально расходящиеся от оптически плотного участка овальной формы (бывший канал интрамедуллярного имплантата).

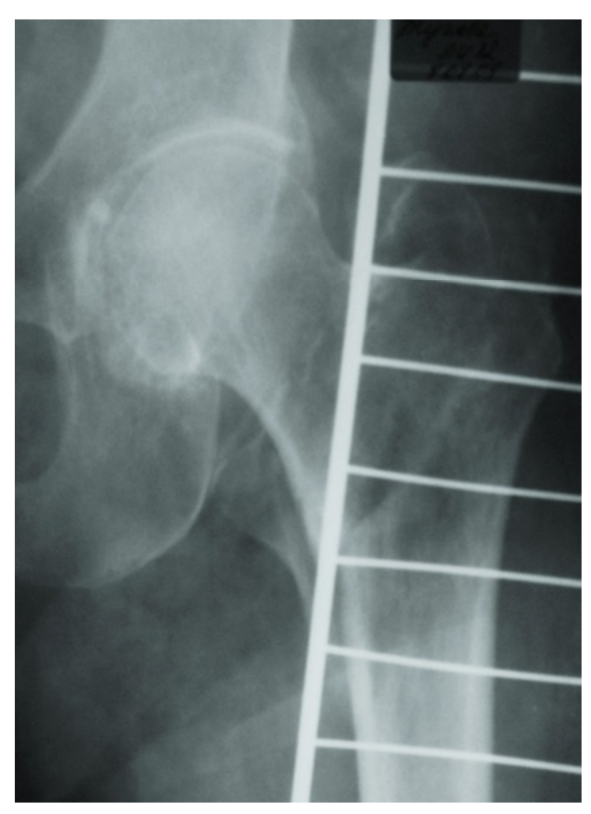

$a$

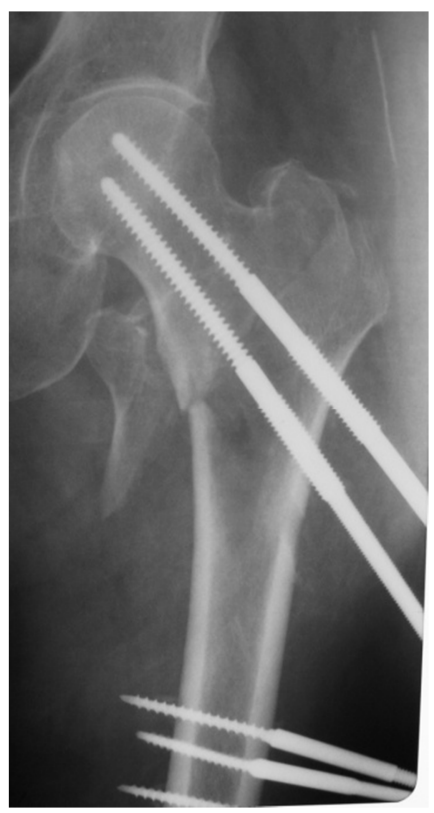

6

B

Рис. 4.16. Пациентка Ж., 82 года: а — рентгенограмма тазобедренного сустава в день травмы; б рентгенограмма тазобедренного сустава после операции; в - внешний вид и функциональные возможности нижней конечности в первые недели после операции. 

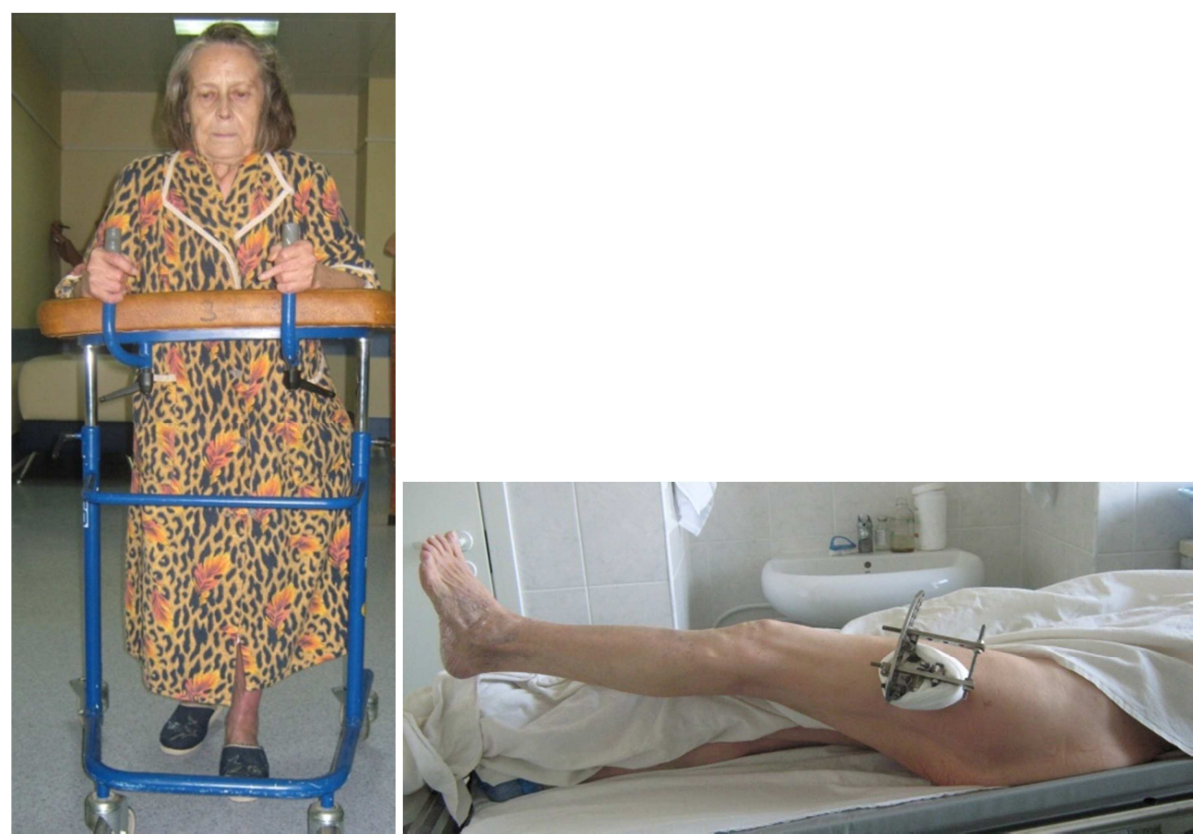

$\mathrm{B}$
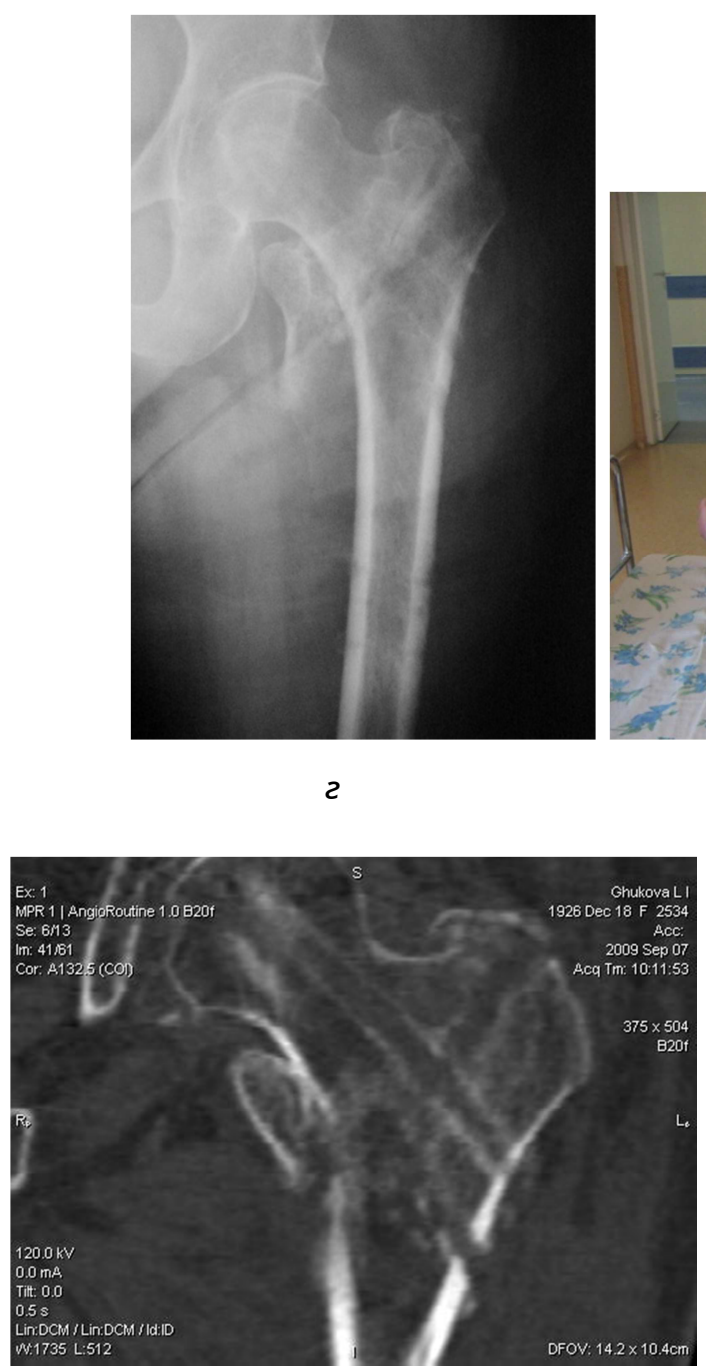

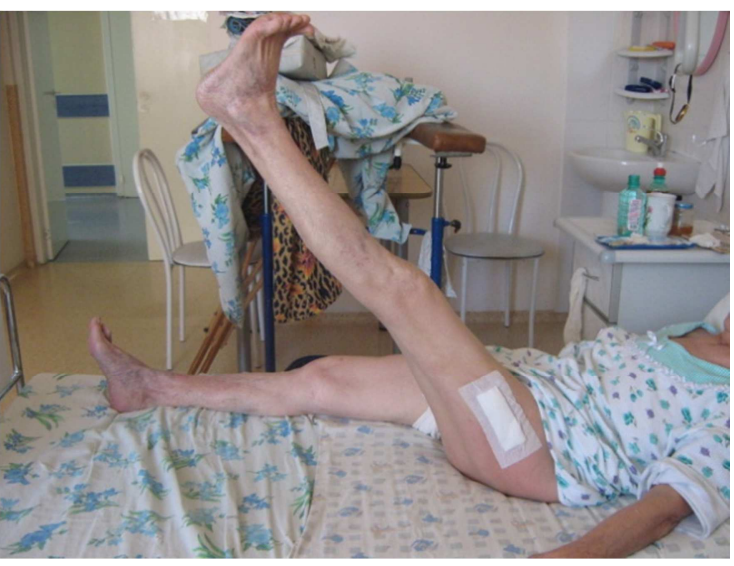

$\partial$

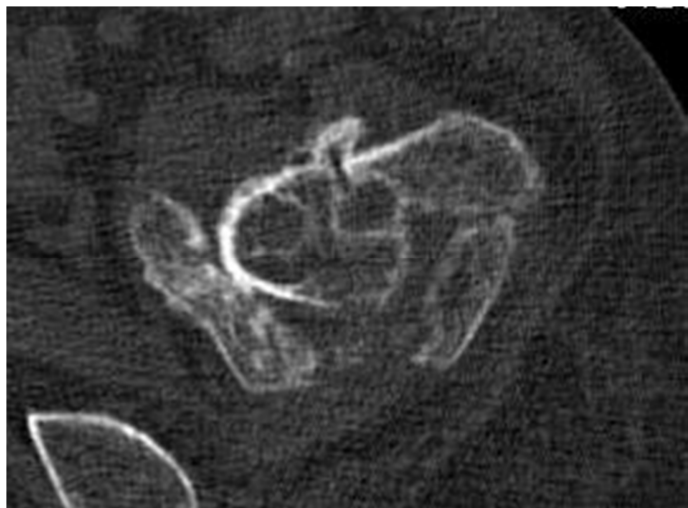

Рис. 4.16. (продолжение). Пациентка Ж., 82 года: г — рентгенограмма тазобедренного сустава в день демонтажа стержневого аппарата; $\partial-$ функциональные возможности нижней конечности в день демонтажа стержневого аппарата; $e$ - компьютерные томограммы тазобедренного сустава через 
3 месяца после операции (на месте удаленных стержней в метафизе, шейке и головке бедра видны участки гиперминерализации толщиной в 3 мм и более).
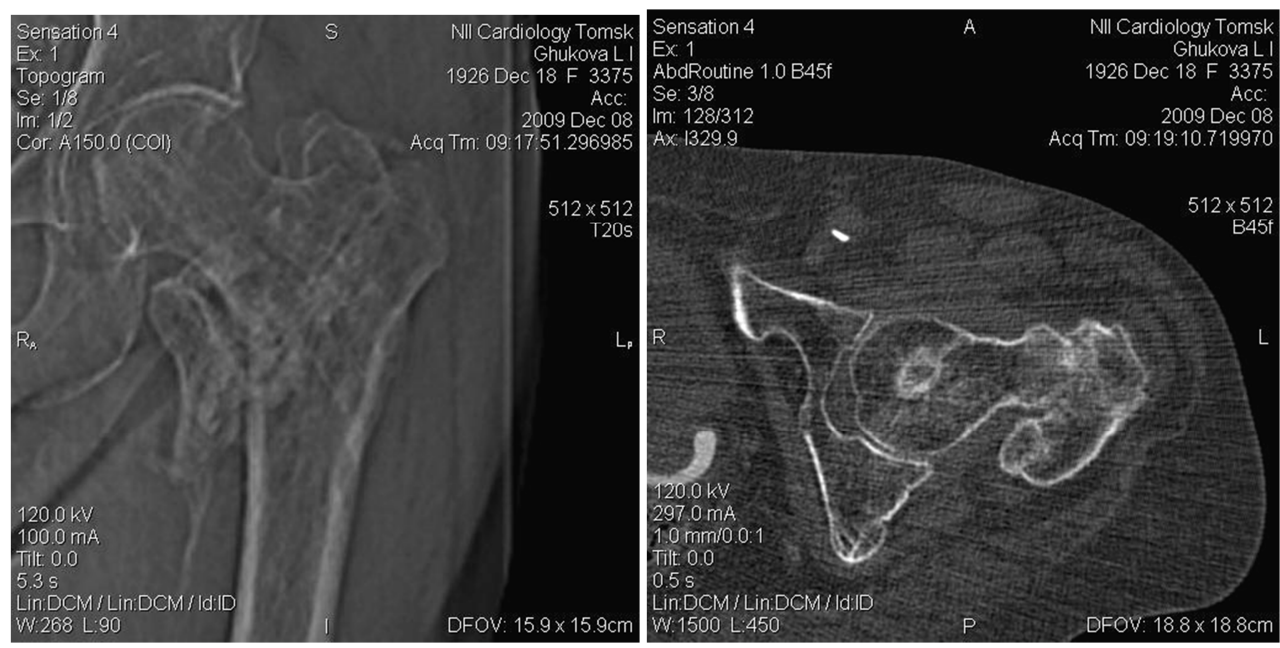

ж
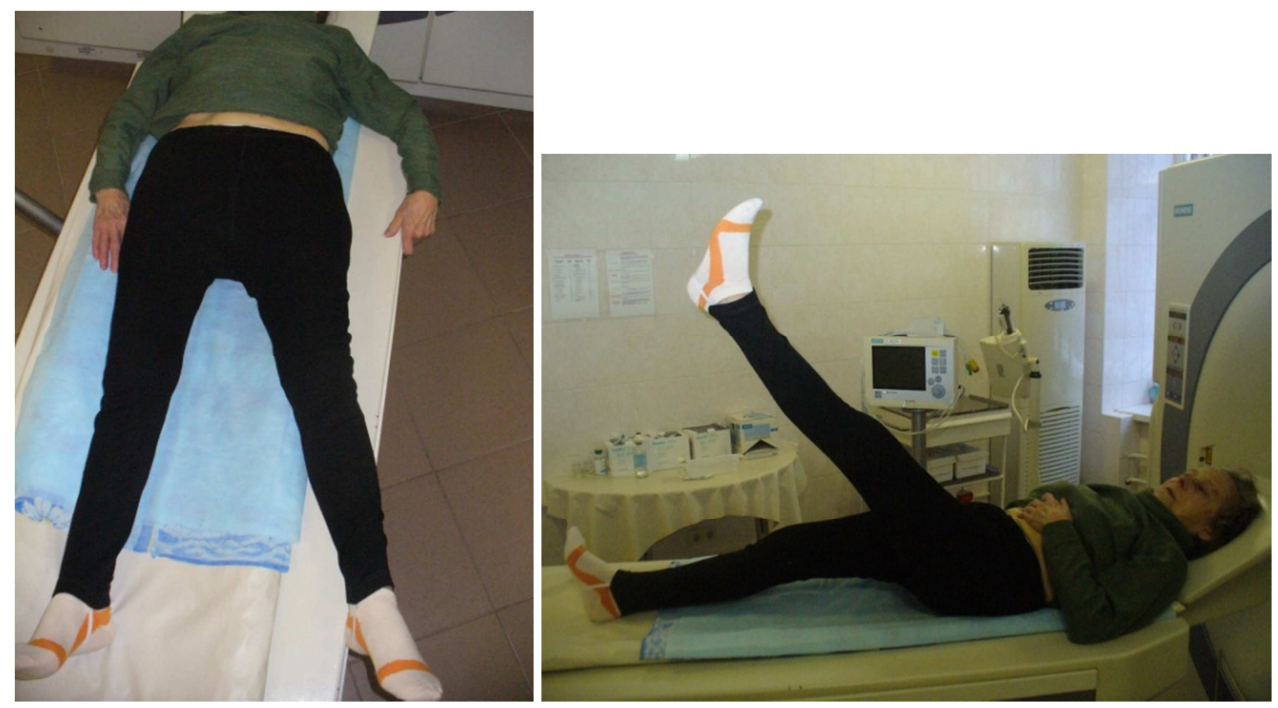

Рис. 4.16. (окончание). Пациентка Ж., 82 года: ж - компьютерные томограммы тазобедренного сустава через 5 месяцев после операции; 3 - внешний вид и функция нижней конечности через 5 месяцев после операции.

Лечение больных с переломами шейки бедренной кости остается одной и наиболее сложных задач клинической травматологии, проблематичность которой в значительной степени обусловлена комплексом взаимосвязанных решений, которые приходится принимать каждому травматологу. Несомненно, что важнейшим из них является вопрос о выборе оптимального для каждого пациента способа лечения и использования соответствующих данному способу технических средств его реализации.

Диапазон этих средств сегодня достаточно обширен и включает в себя, наряду с гипсовой повязкой и приспособлениями для скелетного вытяжения, большое количество 
устройств для остеосинтеза и различные модификации эндопротезов, а также аппаратов внешней фиксации. В той или иной степени все перечисленные средства востребованы клинической практикой.

Малотравматичность используемых методик и ранний активный двигательный режим обеспечивают благоприятные условия для сращения и функционального восстановления конечности.

Индивидуальный подход к лечению пациентов с переломом шейки бедренной кости, при различном характере повреждений, позволяет в условиях чрескостного остеосинтеза найти оптимальный и кратчайший путь к выздоровлению.

\section{4. Остеосинтез диафизарных переломов костей голени}

Переломы костей голени встречаются в 10 раз чаще, чем переломы бедренной кости и составляют 10-12\% среди всех переломов всех костей скелета. Среди переломов длинных трубчатых костей частота переломов костей голени достигает 30-40\%. Переломы берцовых костей различают по уровню: переломы проксимального конца (до 10\%), диафизарные переломы (30-40\%), переломы дистального метаэпифиза (50-60\%).

Переломы тела (диафиза) большеберцовой кости составляют 11,3-41,2 \% от всех переломов костей скелета [Жанаспаев А.М., 1992; Хайдаров Н.С. и др., 2000; Шевцов В.И. и др., 2002]. Несмотря на постоянное совершенствование методов лечения, эти переломы продолжают занимать одно из первых мест по его продолжительности и частоте инвалидности [Матвеев А.Л., 1998; Санникова Е.В., 1999]. Лишь относительно небольшая часть диафизарныхь переломов без смещения срастается в относительно короткие сроки (2-3 месяца). Большинство переломов со смещением, оскольчатые переломы, многооскольчатые, открытые переломы срастаются в течение 4-7 месяцев.

Сроки консолидации обусловлены как характером перелома, так и способом лечения. Сравнивая различные виды остеосинтеза при лечении сегментарных переломов костей голени, многие авторы установили, что накостный остеосинтез требует большого по протяженности хирургического доступа, приводит к увеличению кровопотери и дополнительной травматизации окружающих тканей, ухудшает кровоснабжение зоны перелома, нарушает венозный и лимфатический отток, повышая риск жировой и тромбоэмболии. Остеосинтез интрамедуллярными фиксаторами при сегментарных переломах голени нарушает внутрикостное кровообращение [А.И. Городниченко, А.Н. Минаев, О.Н. Усков, 2010; Кавалерский, Г.М., 2010; Лыжина, Е.Л. с соавт., 2004; Пичхадзе, И.М. ,2006; Соломин Л.Н., 2005; Швед С.И. с соавт., 2006; V.D. Polyzois et al., 2010]. 
Именно при лечении переломов костей голени полнее всего раскрываются возможности чрескостного остеосинтеза: простота применения, возможность точно сопоставить отломки и прочно их фиксировать независимо от вида перелома, успешное лечение ран мягких тканей при открытых травмах, возможность ранней активизации больных. При изолированных переломах внеочаговый остеосинтез применяется в подавляющем большинстве наблюдений: при закрытых диафизарных переломах - в 74,8\% случаев, при открытых - в 88,8\% [Викторова, Н.Л. , 1995; H.L. Tucker, J.C. Kendra, T.E. Kinnebrew, 1992].

Аппараты внешней фиксации оказались универсальным инструментом при лечении сложных переломов гостей голени. Время сращения составляет от 5 до 7,5 месяцев, период остеосинтеза - от 4 до 7 месяцев. Хорошие и отличные результаты зарегистрированы в 43-95\% случаев. Основным осложнением является инфицирование в местах проведения спиц, которое развивается в среднем у 27-28\% больных (от 10,7\% до 46\%). Несколько реже встречаются рефрактуры - 8,8\%. Несмотря на технические трудности и проблемы, связанные с опасностью воспаления мягких тканей в области спиц, чрескостный остеосинтез АВФ признается методом выбора при лечении открытых переломов голени благодаря высокой степени сращения, минимальной травматичности метода, отличным функциональным результатам, возможности ранней активизации больных [Capo, J.T. et al., 2009].

Опыт крупных научных центров лечения больных с переломами длинных трубчатых костей доказывает необходимость развития таких методов, которые при достаточной простоте и малой травматичности способствовали бы ранней активизации больных, сокращению сроков лечения, снижению экономических затрат [Барабаш А.П., Соломин Л.Н., 1992; Корнилов Н.В., 2001; Николайчук Е.В., 2004; Швед С.И. с соавт., 2000]. В наибольшей степени этим требованиям отвечает метод интрамедуллярного напряженного армирования большеберцовой кости спицами с ГА-покрытием позволяет стимулировать эндостальное костеобразование и ограничить сроки фиксации голени аппаратом Илизарова вплоть до 3-4 недель. При таких незначительных сроках остеосинтеза мы рекомендуем воспользоваться временной иммобилизацией с помощью современных функциональных ортезов [Скороглядов А.В. и др., 2012] либо ортеза из гипсовых бинтов, чтобы максимально сохранить функцию коленного и голеностопного суставов. Дополнительная иммобилизация обычно продолжается 1 месяц и позволяет больному ходить с частичной нагрузкой на поврежденную конечность.

Клинический пример. Пациент Б., 25 лет. Диагноз: закрытый оскольчатый перелом диафиза правой большеберцовой кости со смещением (рис. 4.17). 
Операция: закрытый остеосинтез костей голени аппаратом Илизарова, напряженное интрамедуллярное армирование большеберцовой кости спицами с ГА-покрытием.

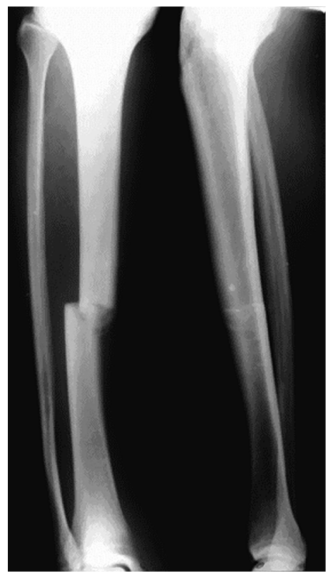

$a$

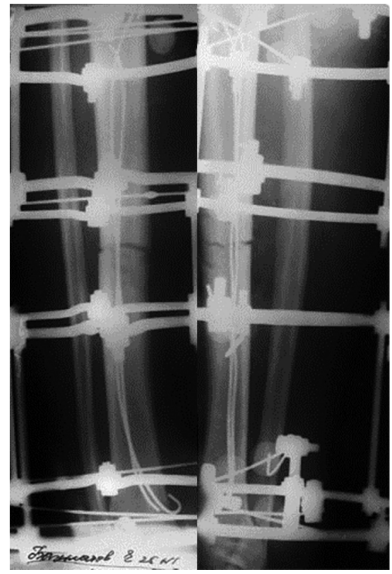

6

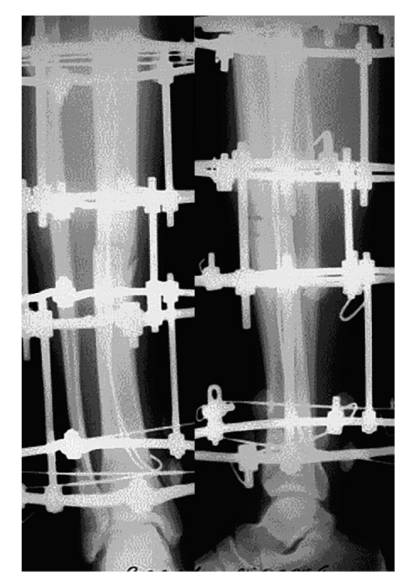

B

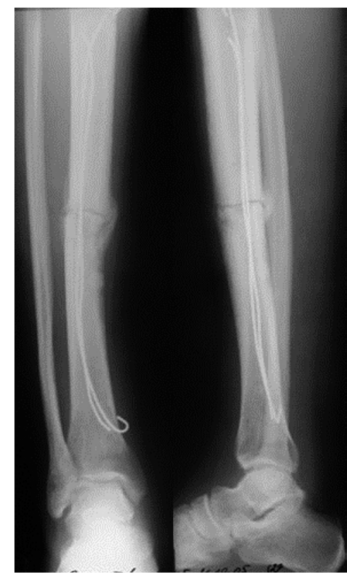

Рис. 4.17. Пациент Б., 25 лет: а — рентгенограмма костей голени в день травмы; б - рентгенограмма костей голени в день операции; в - - рентгенограмма костей голени через 19 дней после операции (аппарат в этот день демонтирован); г - рентгенограмма костей голени через 50 дней после операции.

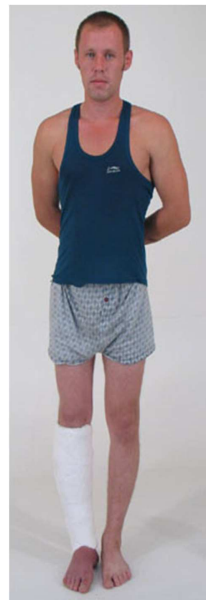

$\partial$

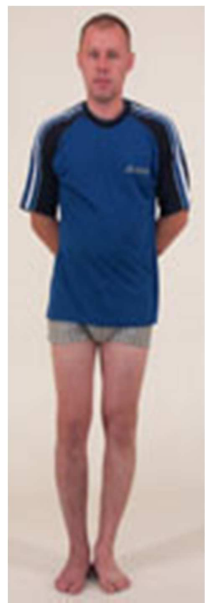

e
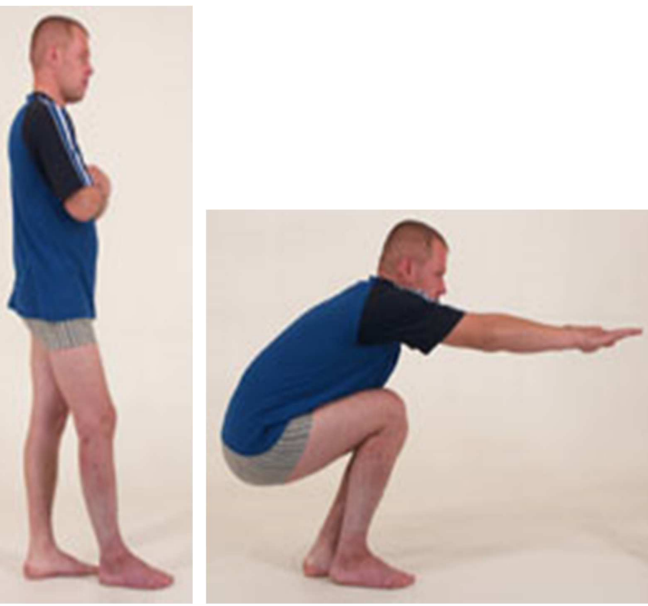

Рис. 4.17. (продолжение). Пациент Б., 25 лет:д - пациент в день снятия аппарата (иммобилизация голени гипсовым ортезом); е - внешний вид и функция нижней конечности через 50 дней после операции.

Через 19 дней фиксации на рентгенограммах голени проявились первые признаки репаративной регенерации (между костными фрагментами стали видны отдельные тени вновь образованного регенерата). Это послужило основанием для демонтажа аппарата и продолжения иммобилизации голени гипсовым ортезом. Через 1 месяц ортез был снят. Через 3 месяца после операции у пациента полностью восстановилась трудоспособность.

Клинический пример. Пациентка С., 25 лет. Диагноз: застарелый (2,5 месяца) открытый оскольчатый перелом диафиза правой большеберцовой кости (рис.4.18).

Лечение проводилось консервативно - циркулярная гипсовая повязка от проксимальной трети бедра до кончиков пальцев. Отсутствие каких-либо рентгенологических признаков репаративной 
регенерации кости позволило высказать предположение о замедленной консолидации и рекомендовать оперативное лечение.

Операция: закрытый остеосинтез костей голени аппаратом Илизарова, интрамедуллярное армирование большеберцовой кости спицами с ГА-покрытием.
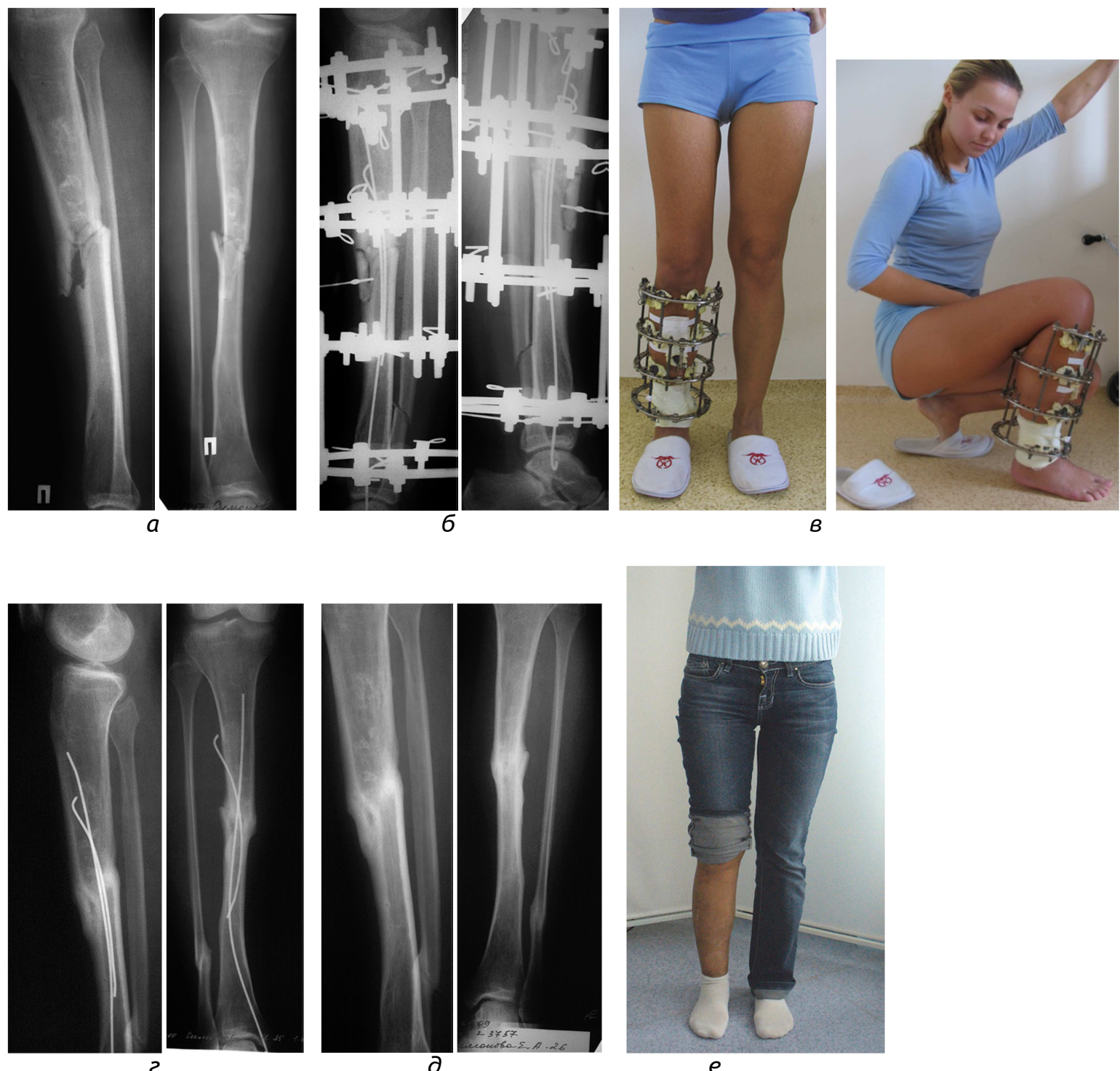

Puc. 4.18. Пациентка С., 25 лет: $a$ - рентгенограммы костей голени до лечения; 6 - рентгенограммы костей голени после операции; в - внешний вид и функция нижней конечности в процессе остеосинтеза; г - рентгенограммы костей голени через 2 месяца после операции (демонтаж аппарата Илизарова); $\partial$ - рентгенограммы костей голени через 7 месяцев после операции (интрамедуллярные спицы удалены); $e$ - внешний вид через 7 месяцев после операции.

Фиксация голени аппаратом продолжалась 2 месяца и завершилась консолидацией кости. Больная лечилась амбулаторно. После демонтажа аппарата дополнительную иммобилизацию не применяли. Интрамедуллярные спицы удалены через 7 месяцев после операции.

Клинический пример. Пациент Я., 47 лет. Диагноз: закрытый винтообразный перелом дистальной трети диафиза правой голени (рис. 4.19 a).

Операция: закрытый остеосинтез костей голени аппаратом Илизарова, напряженное интрамедуллярное армирование большеберцовой кости спицами с ГА-покрытием (рис. 4.19 б). 
Через 30 дней на контрольной рентгенограмме отчетливо видны первые признаки репаративной регенерации кости в виде облаковидных теней между костными фрагментами и легкой дымки периостальной реакции на уровне перелома (рис. 4.19 в). Такие признаки регенерации достаточны для проведения клинической пробы на консолидацию и демонтажа аппарата Илизарова (рис. 4.19 г).

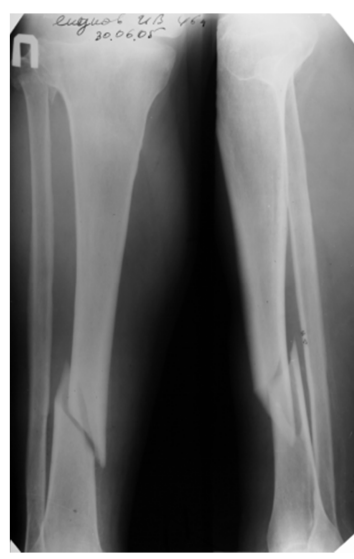

a

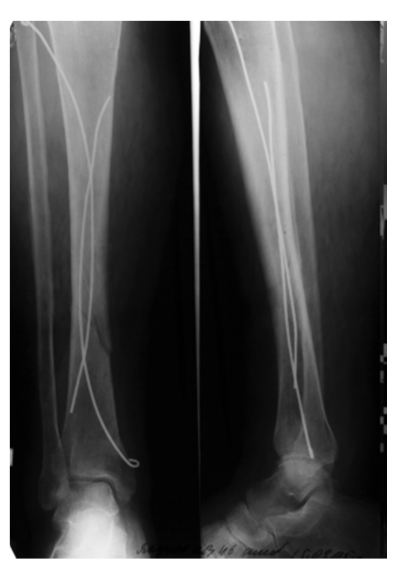

$\Gamma$

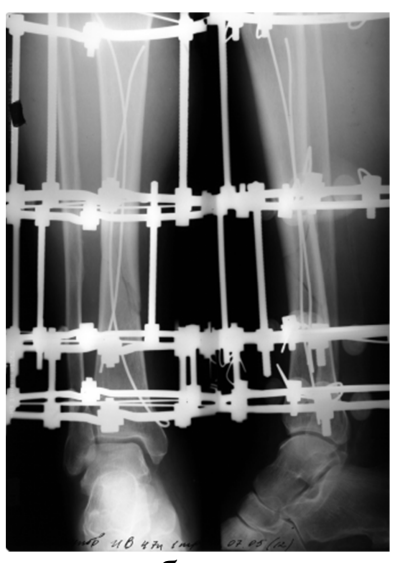

6

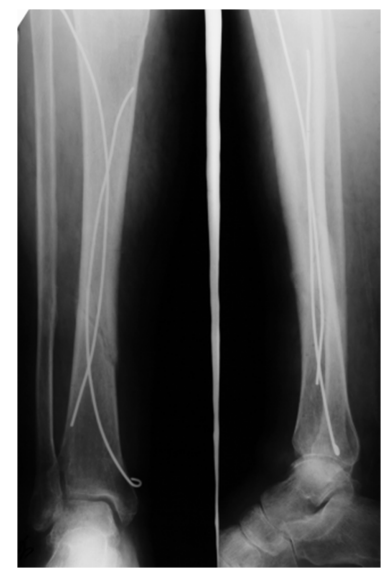

д

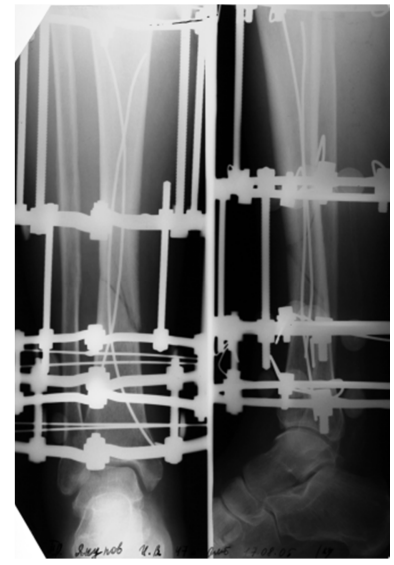

B

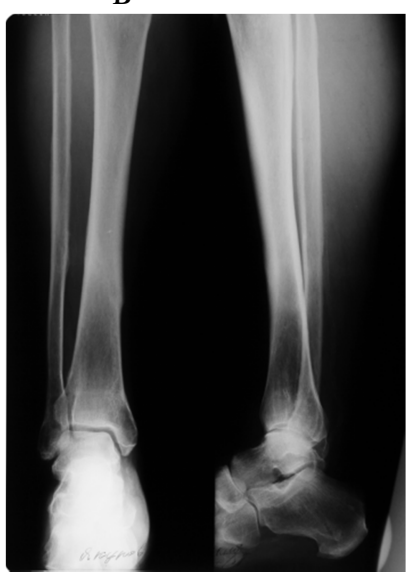

e

Рис. 4.19. Пациент Я., 47 лет: а - рентгенограммы костей голени до лечения; б - рентгенограммы костей голени в день операции; в - рентгенограммы костец голени через месяц после операции (отчетливо видны признаки репаративной регенерации - можно снимать аппарат); г рентгенограммы костей голени в день демонтажа аппарата Илизарова; д — рентгенограммы костей голени через 3 месяца (интрамедуллярные спицы в этот день удалили); е рентгенограммы костей голени через 2,5 года после остеосинтеза.

После демонтажа аппарата больной начал ходить практически с полной нагрузкой. Через 3 месяца ему удалили интрамедуллярные спицы (рис. 4.19 д) - к этому времени функциональная реабилитация была завершена. Отдаленный результат прослежен до 2,5 лет (рис. 4.19 е).

Клинический пример. Пациентка И., 35 лет. Диагноз: закрытый перелом костей левой голени (рис. 4.20).

Операция: закрытый остеосинтез костей голени аппаратом Илизарова, интрамедуллярное армирование большеберцовой кости спицами с ГА-покрытием. 


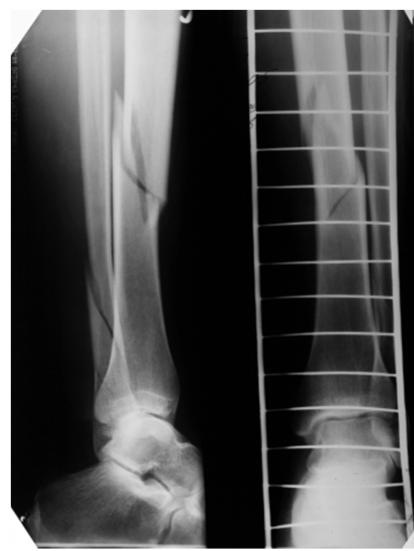

a

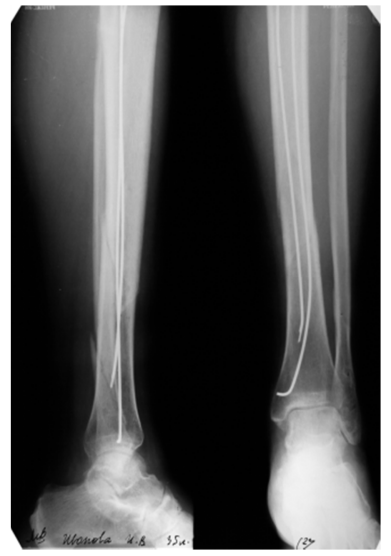

$\Gamma$

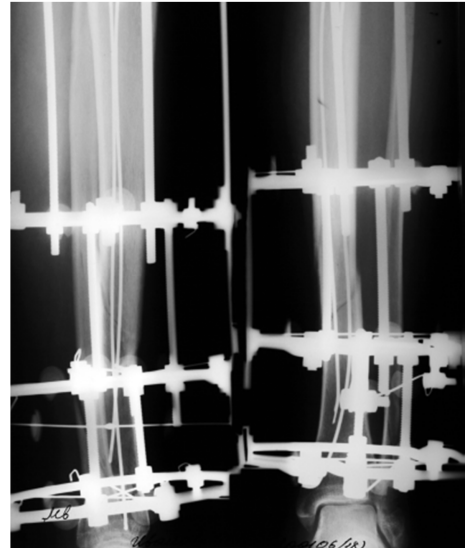

б

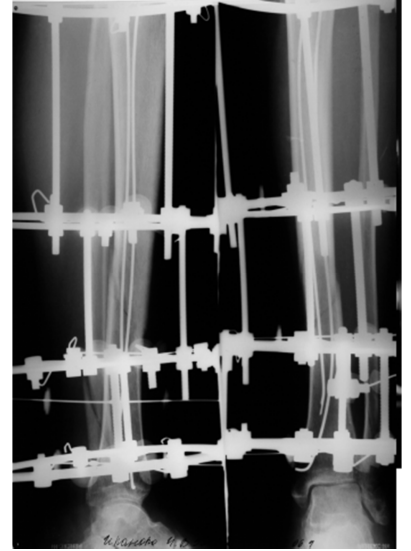

B

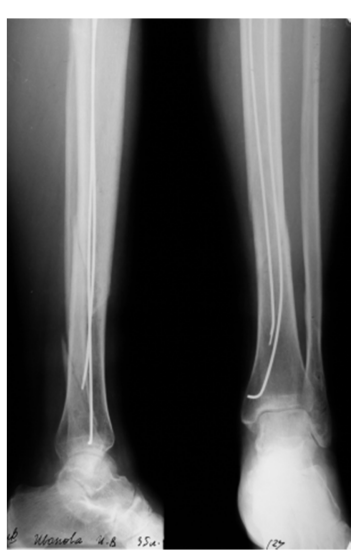

д

Рис. 4.20. Пациентка С., 25 лет: а — рентгенограммы костей голени до лечения; б - рентгенограммы костей голени после операции; в - рентгенограммы костей голени через 46 дней после операции; г демонтаж аппарата Илизарова; д — рентгенограммы костей голени через 52 дня после демонтажа аппаората.

Фиксация голени аппаратом продолжалась 1,5 месяца, когда на рентгенграммах стали отчетливо видны признаки консолидации кости. Больная лечилась амбулаторно. После демонтажа аппарата дополнительную иммобилизацию не применяли. Интрамедуллярные спицы удалены через 3 месяцев после операции.

\section{5. Остеосинтез диафизарных переломов плечевой кости}

Переломы диафиза плечевой кости составляют 2,2-2,9 \% от всех переломов костей скелета, а среди переломов длинных трубчатых костей - 5,4-20,8 \%, оскольчатые переломы среди них достигают 32,6 \%. Частота такого сложного вида переломов с возможностью повреждения нервных стволов и нарушения функции верхней конечности определяет актуальность данной проблемы в повседневной жизни.

При диафизарных переломах верхних конечностей аппараты внешней фиксации применяются достаточно редко: в 25-42\% случаев при закрытых повреждениях и в 50\% при открытых [Викторова, Н.Л. , 1995; Сысенко Ю.М. с соавт., 1998]. С тех пор, как в 1964 г. L. Böhler заявил, что хирургическое вмешательство должно быть исключением при 
лечении переломов плечевой кости, прошло много времени, и теперь оперативное лечение является «золотым стандартом» благодаря развитию новых способов интрамедуллярного и накостного остеосинтеза. Аппараты внешней фиксации также используются для первичной стабилизации переломов при политравме или как метод выбора при лечении их осложнений.

При лечении закрытых диафизарных оскольчатых переломов длинных трубчатых костей верхних конечностей методом ЧО гарантией успешного результата является точное сопоставление не только основных, но и мелких отломков, а также их стабильная управляемая фиксация. Нет особых противопоказаний к применению метода у этой категории больных, кроме заболеваний жизненно важных органов и систем в стадии декомпенсации, а также гнойных заболеваний кожи и подкожно-жировой клетчатки в зоне операции [Кулик, В.И. с соавт., 2000; Пичхадзе, И.М. 2006; Соломин Л.Н., 2005; Стадников, В.В., 2004; Karapinar, H. et al., 2010; Reynders P. Et al., 2009].

Основываясь на результатах лечения 514 больных с переломами диафиза плечевой кости, Т.Б. Раенгулов [Кулик, В.И. с соавт., 2000] считает, что предпочтение следует отдавать методам стабильной фиксации: аппаратам внешней фиксации и пластинам.

Абсолютным показанием к применению внеочагового остеосинтеза являются сложные многооскольчатые переломы, при которых остеосинтез пластиной требует большого травматичного доступа. С целью снижения травматичности и трудоемкости лечения закрытых нестабильных переломов диафиза плечевой кости предлагается использовать комбинированный метод фиксации, который может осуществляться в ургентном порядке, в условиях перевязочной, одним хирургом. Об успешном лечении открытых переломов плечевой кости у 15 пациентов с применением монолатеральных аппаратов внешней фиксации сообщают I.L. Marsh с соавторами [1999]. Средний срок фиксации составил 21 неделю, все больные довольны результатами лечения. Использование аппаратов такого же типа в сочетании с открытой репозицией и ограниченной внутренней фиксацией пластиной позволило добиться сращения переломов в нижней трети плечевой кости в среднем в течение 14 недель. Установлено, что при переломах данной локализации применение шарнирных монолатеральных аппаратов в качестве дополнительных фиксаторов увеличивает стабильность остеосинтеза пластиной.

Особую сложность в оперативном лечении этой патологии представляют больные пожилого и старческого возраста - выраженный остеопороз крайне затрудняет возможность фиксации костных отломков любыми средствами (проволока, накостные пластины, чрес- или внутрикостный остеосинтез). Неудивительно, что число несросшихся переломов и ложных суставов плеча достигает 19,8-30\%. 
Интрамедуллярный остеосинтез спицами с биоактивным ГА-покрытием позволяет одновременно со стимуляцией репаративного остеогенеза активно решать проблему остеопороза у пострадавших пожилого возраста.

Клинический пример. Пациентка Ш., 77 лет. Диагноз: остеопороз, закрытый винтообразный перелом правой плечевой кости (рис. 4.21).

Операция: закрытая репозиция костных отломков, остеосинтез аппаратом Илизарова после интрамедуллярного армирования плечевой кости спицами с биоактивным ГА-покрытием.

Срок фиксации аппаратом Илизарова составил 1,5 месяца, а через 3 месяца после операции удалили и интрамедуллярные спицы.

Функциональный результат мы проконтролировали через 6 месяцев после операции и убедились в полной реабилитации пациентки.

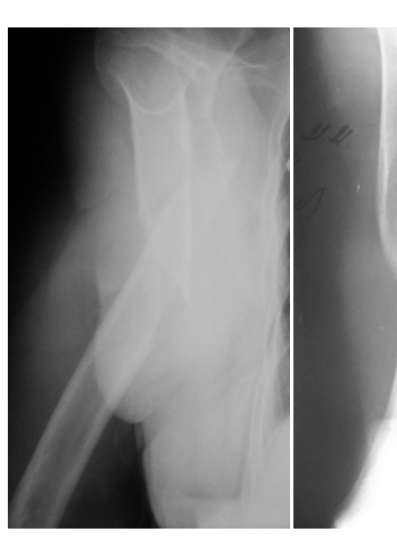

$a$
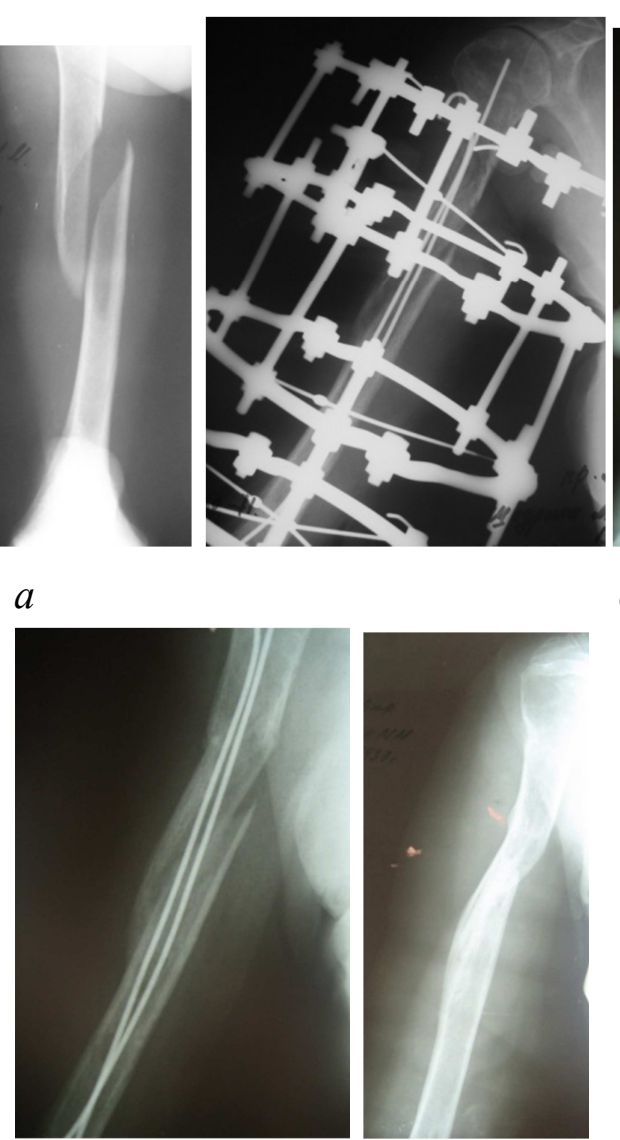

B

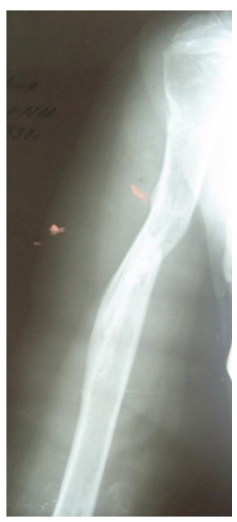

2

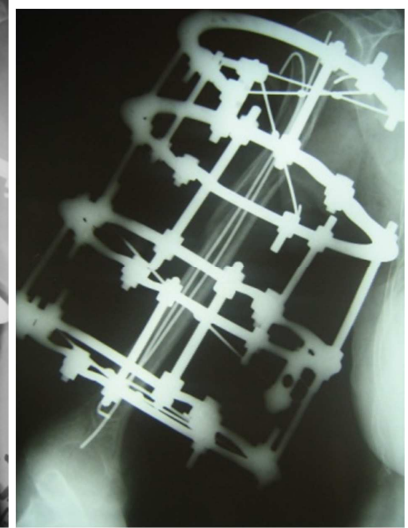

б

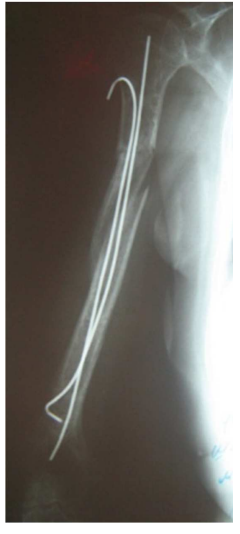




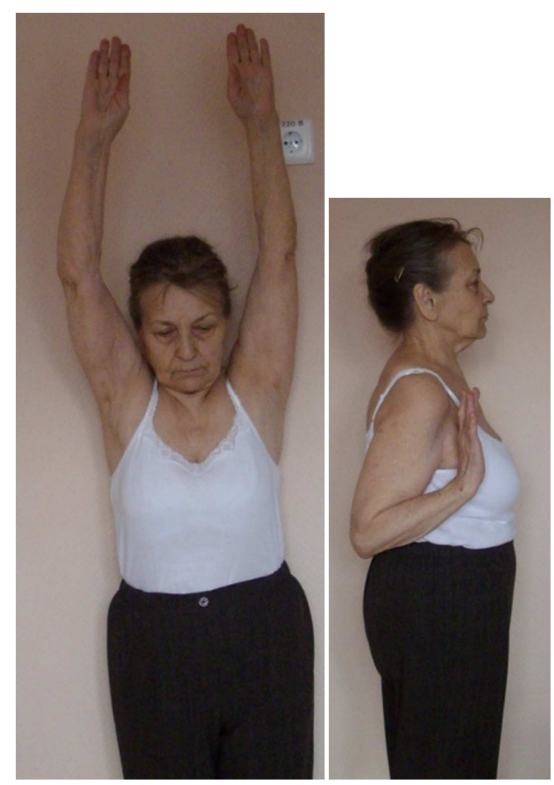

$\partial$

Рис. 4.21. Пациентка Ш., 77 лет: а — рентгенограммы плечевой кости до лечения; б - рентгенограммы плечевой кости в процессе остеосинтеза аппаратом Илизарова; в - рентгенограммы плечевой кости через 6 недель после операции (аппарат Илизарова демонтирован); 2 — рентгенограммы плечевой кости через 3 месяца после операции (полная консолидация); $\partial-$ внешний вид и функция верхней конечности через 6 месяцев после операции.

Клинический пример. Пациентка В., 70 лет. Диагноз: закрытый оскольчатый перелом левой плечевой кости, остеопороз (рис. 4.22).

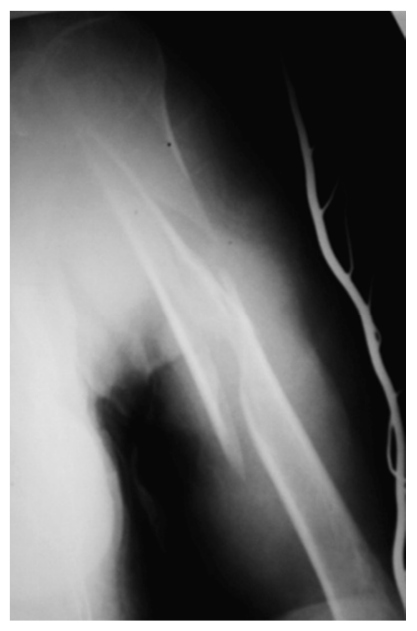

$a$

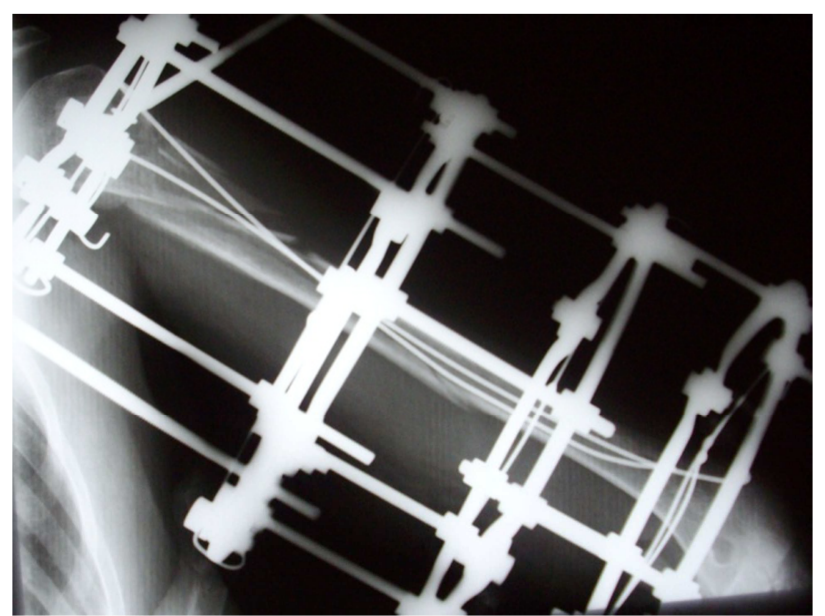

$\sigma$ 


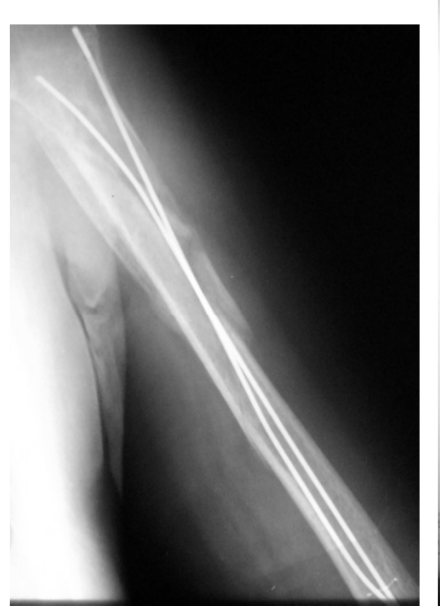

B

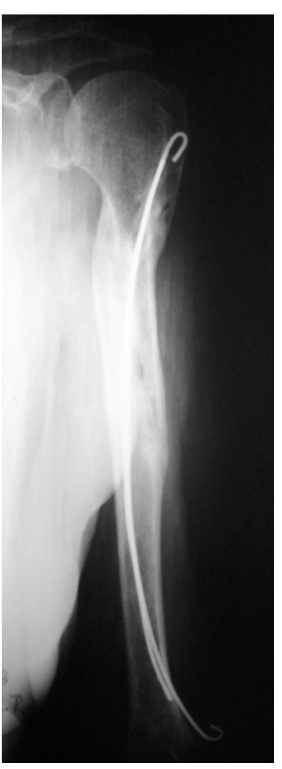

2

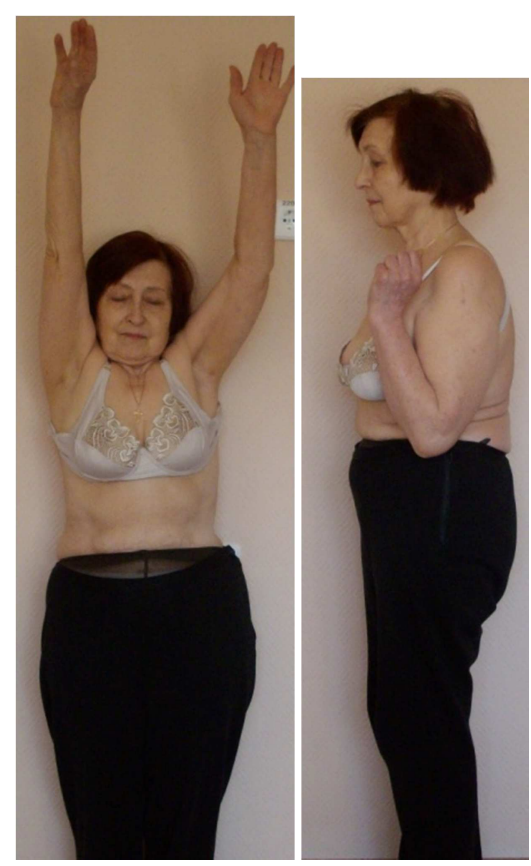

$\partial$

Рис. 4.22. Пациентка В., 70 лет: а — рентгенограмма плечевой кости до лечения; б - рентгенограмма плечевой кости в день операции; в - рентгенограмма плечевой кости через 6 недель после операции (аппарат Илизарова демонтирован); г - рентгенограмма плечевой кости через 6 месяцев после операции; д - внешний вид и функция верхней конечности через 6 месяцев после операции.

Операция: остеосинтез плечевой кости аппаратом Илизарова, интрамедуллярное армирование спицами с ГА-покрытием.

Фиксация аппаратом Илизарова продолжалась 6 недель, после чего диагносцирована консолидация кости.

Полная функциональная реабилитация подтверждена при контрольном осмотре через 6 месяцев после травмы. Удалять интрамедуллярные спицы пациентка отказалась.

Клинический пример. Пациентка С., 18 лет. Диагноз: закрытый оскольчатый перелом левой плечевой кости (рис. 4.23).

Операция: остеосинтез плечевой кости аппаратом Илизарова, интрамедуллярное армирование спицами с биоактивным ГА-покрытием.

Фиксация аппаратом Илизарова продолжалась 3 недели. После демонтажа аппарата дополнительную иммобилизацию конечности не проводили.

Контрольный осмотр через 6 недель после демонтажа аппарата подтвердил полную консолидацию кости и восстановление трудоспособности пациентки. 

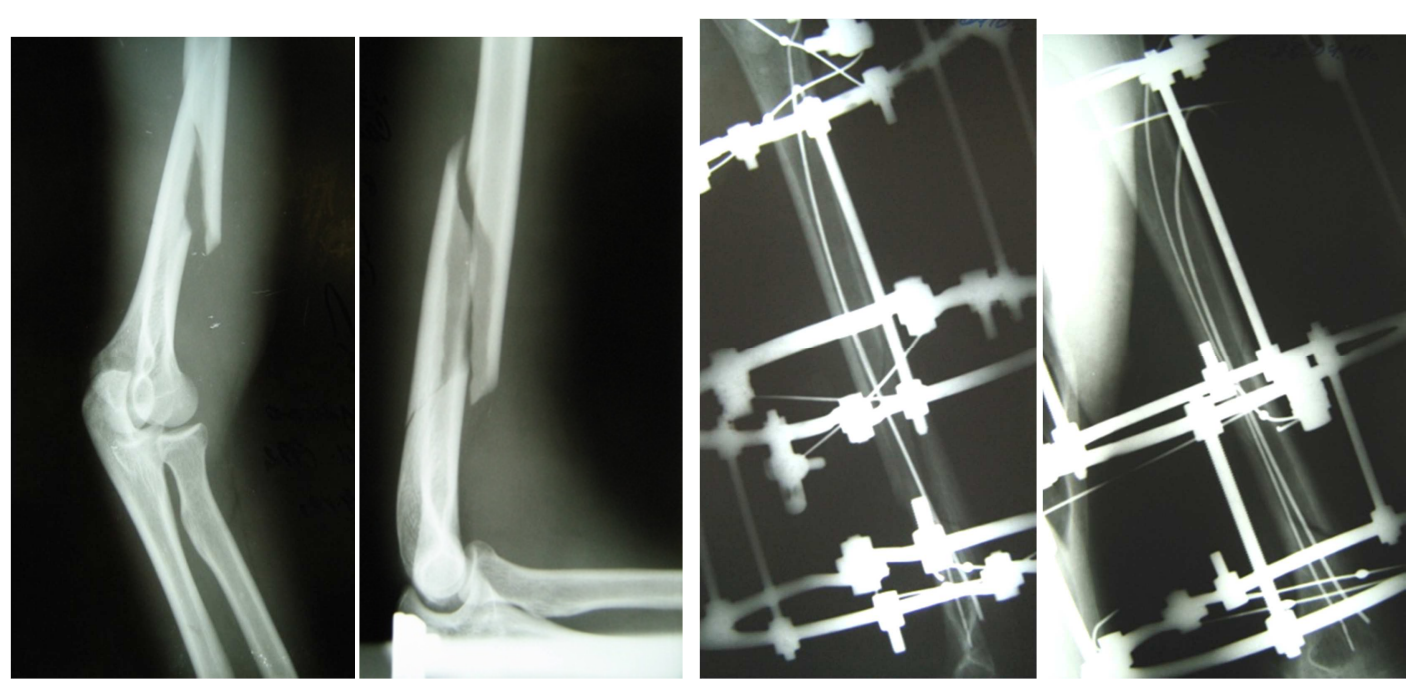

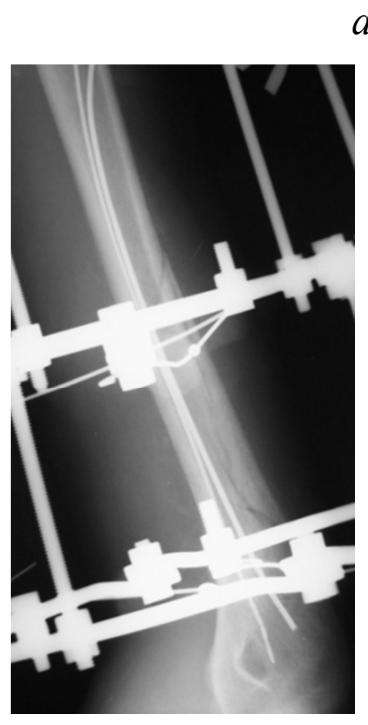

B $a$

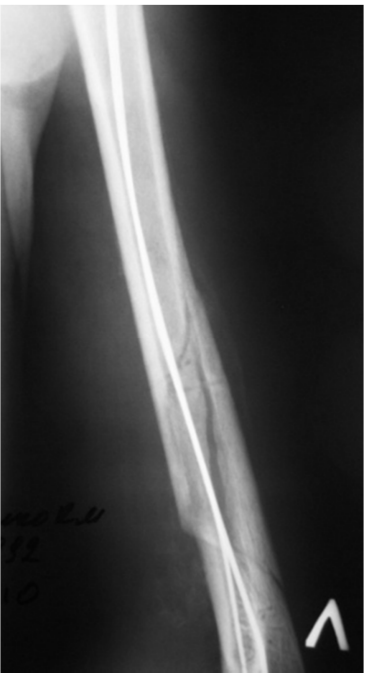

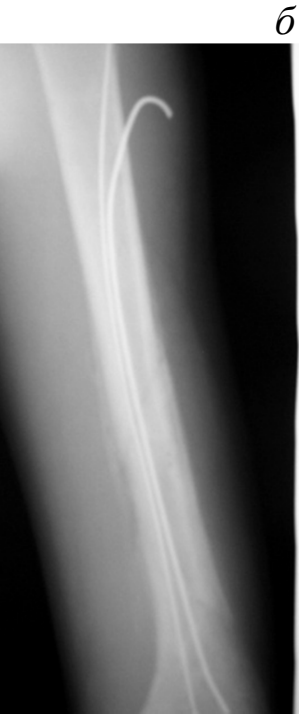

$\partial$

Рис. 4.23. Рентгенограммы плечевой кости пациентки С., 18 лет: а — до лечения; б — в день операции; в через 3 недели после операции; г - после демонтажа аппарата Илизарова (наступила консолидация); д - через 6 недель после демонтажа аппарата Илизарова (контрольный осмотр).

Нужно отметить, что аппарат Илизарова в классической комплектации (4 кольцевых опоры) значительно нарушает комфортность пребывания пациента в быту при амбулаторном лечении, поэтому мы предлагаем чаще использовать монолатеральные АВФ при комбинированном остеосинтезе при интрамедуллярном введении спиц с ГА покрытием (Рис.4.24). Используемые консольные стержни-шурупы тоже желательно покрыть биоактивным слоем гидроксиапатита. Это полностью предотвратит возможное воспаление мягких тканей. 


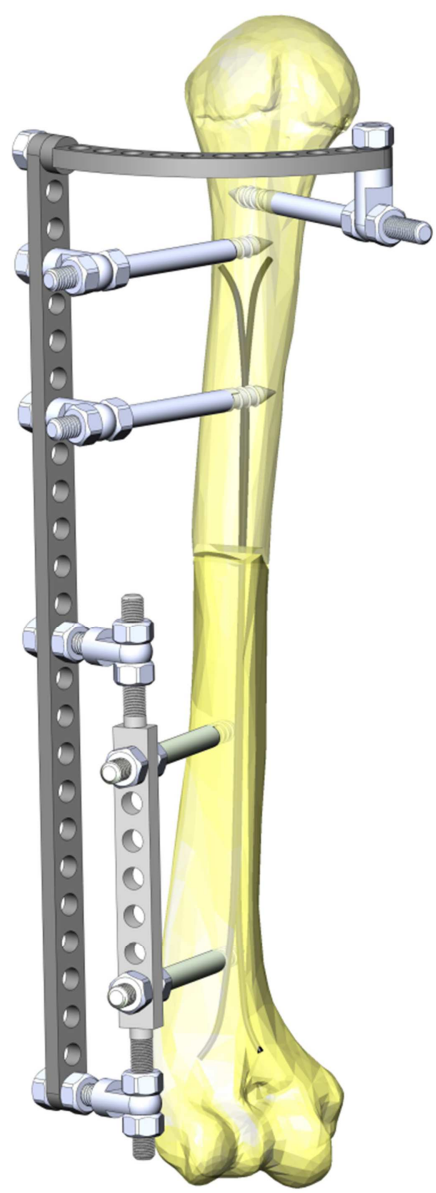

Рис. 4.24. Схема комбинированного остеосинтеза плечевой кости монолатеральным аппаратом с интрамедуллярным армированием спицами с ГА покрытием.

С точки зрения безопасности введения интрамедуллярной спицы в плечевую кость предпочтительнее область проксимального метафиза (рис. 4.25): огромная зона по передней, наружной и задней поверхностям кости доступна для малотравматичного хирургического подхода с исключением риска повреждения каких-либо жизненно важных анатомических образований.

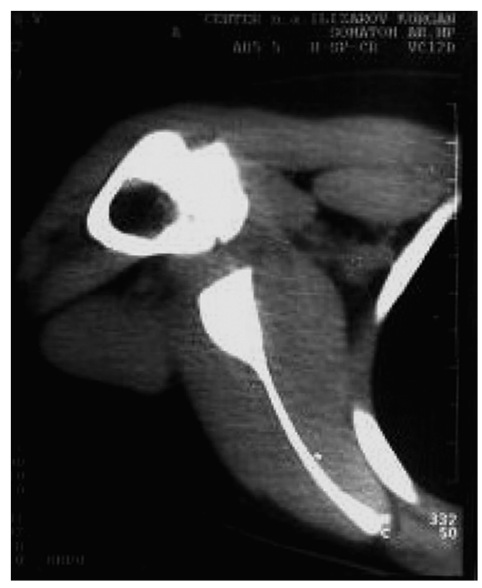

a

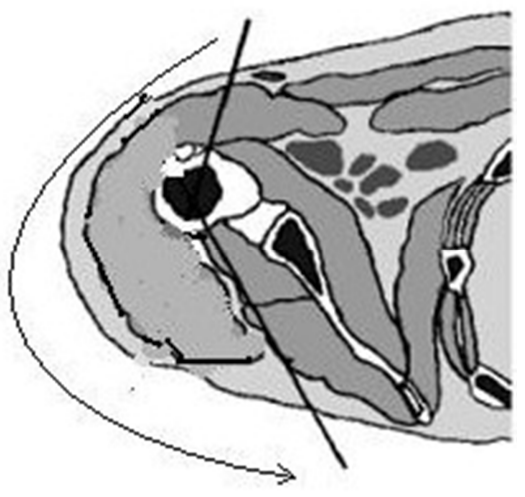

б 
Рис. 4.25. Поперечный срез плечевой кости на уровне проксимальной трети с сектором безопасного введения интрамедуллярной спицы: а — компьютерная томограмма; б - схема.

В области дистального метафиза сектор безопасного подхода к кости ограничен 30$40^{\circ}$ по наружной и внутренней поверхностям: отклонение от этого сектора может привести к повреждению нервов и сосудов - r. profundus $n$. radialis, $n$. ulnaris, $n$. cutaneus antebrachii medialis, a. collateralis ulnaris superior (рис. 4.26).

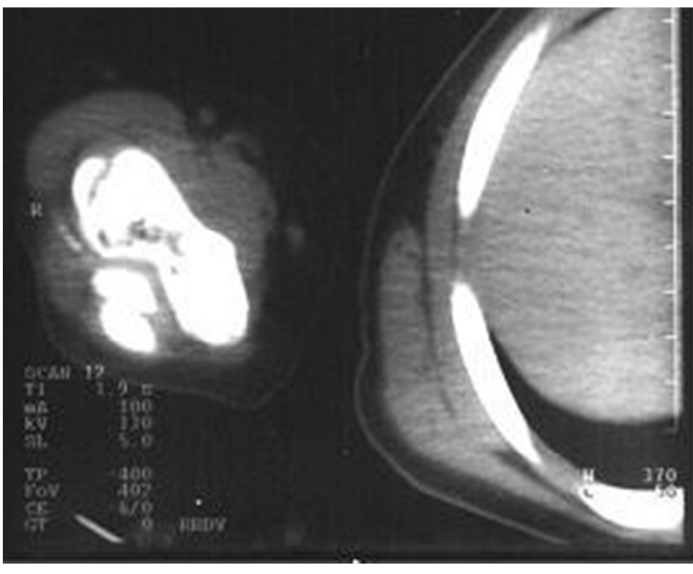

$a$

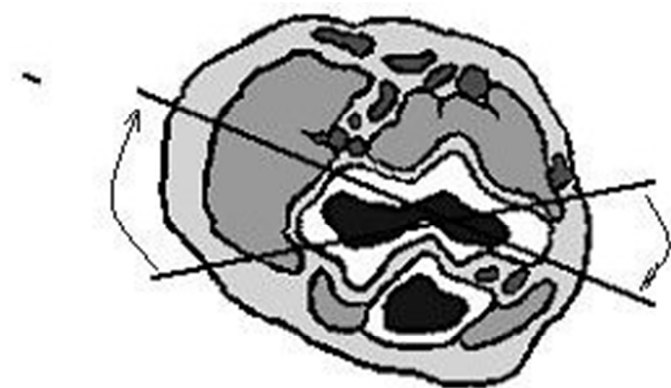

6

Рис. 4.26. Поперечный срез плечевой кости на уровне дистального метафиза с сектором безопасного введения интрамедуллярной спицы: а — компьютерная томограмма; б — схема.

Клинический пример. Больной Ч., 26 лет. Диагноз: Сочетанная травма: разрыв печени, закрытый оскольчатый перелом правого плеча, закрытый перелом левой локтевой кости (Рис.4.27a). Тяжесть состояния по системе ISS оценена в 29 пунктов.

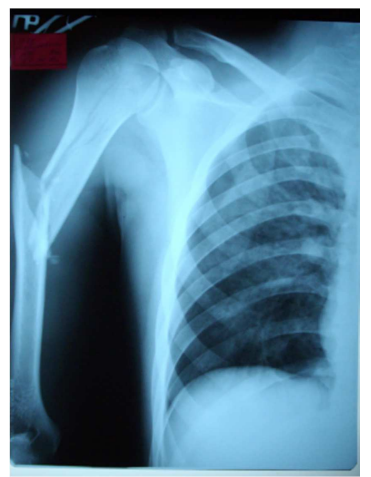

$\mathrm{a}$

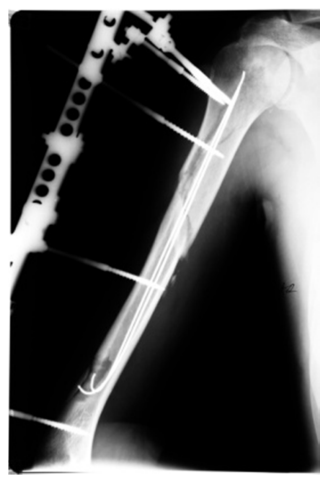

6

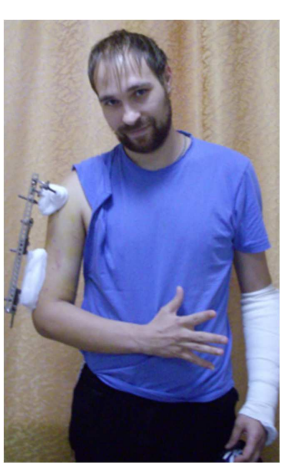

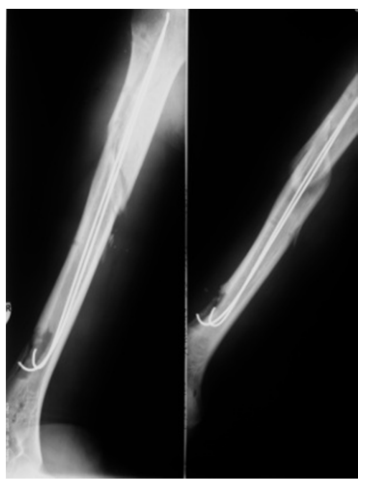

B
$\Gamma$

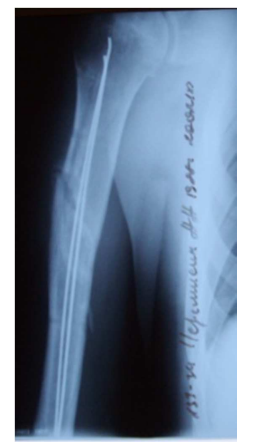

д

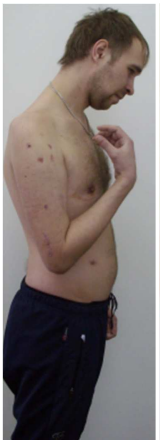

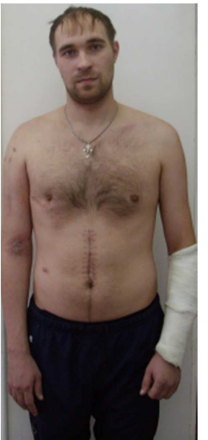

e

Рис.4.27. Больной Ч., 26 лет. Диагноз -Политравма:закрытый оскольчатый перелом правого плеча, закрытый перелом диафиза левой локтевой кости, разрыв печени: рентгенограмма правого плеча до лечения (а), после комбинированного остеосинтеза(б), в- фото больного во время амбулаторного лечения, г - рентгенограммы 
плеча через месяц после операции (аппарат демонтирован), д-е рентгенограммы плеча и фото больного через 2 мес. после демонтажа аппарата.

Травму получил в результате ДТП. Машиной скорой помощи эвакуирован в ЦРБ где произведена лапаротомия и ушивание разрыва печени, временная иммобилизация травмированных конечностей гипсовыми лангетами. Через 10 дней, после стабилизации состоянии жизненно важных функций больного, уже в отделение политравмы II городской больницы г.Кургана произвели отсроченную репозицию и комбинированный остеосинтез правого плеча монолатеральным аппаратом (Рис. 4.27б). Иммобилизация аппаратом практически не ограничивала функцию конечности (Рис. 4.27в). Через месяц проведена клиническая проба на консолидацию, которая подтвердила, что какой-либо подвижности в зоне перелома кости нет. На рентгенограммах в это время отмечены периостальные тени в зоне перелома, отчетливые тяжи костного регенерата в интермедиарной зоне диафизарного перелома и консолидация отломков в зоне проксимального метафиза плеча (Рис. 4.27г). Аппарат был демонтирован. При контрольном осмотре через 2 месяца отмечено полное восстановление функции локтевого сустава(Рис. 4.27д).

Клинический пример. Больная К., 28 лет. Диагноз: Закрытый поперечный перелом диафиза левого плеча с полным смещением отломков (Рис. 4.28a).

Операция: 17.02.2015 - комбинированный остеосинтез левого плеча монолатеральным АВФ (Рис. 4.28б).

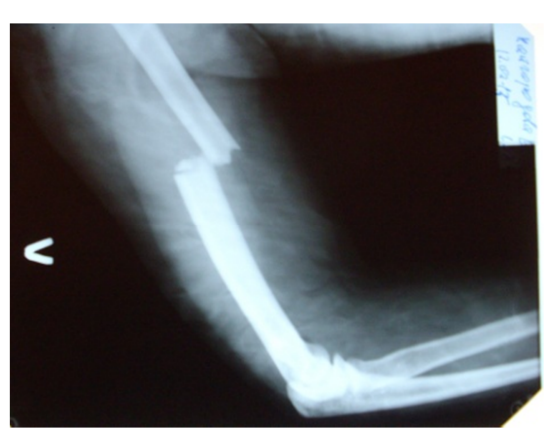

a

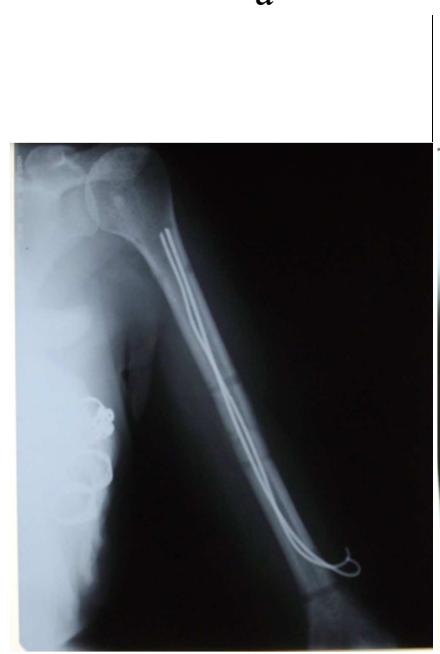

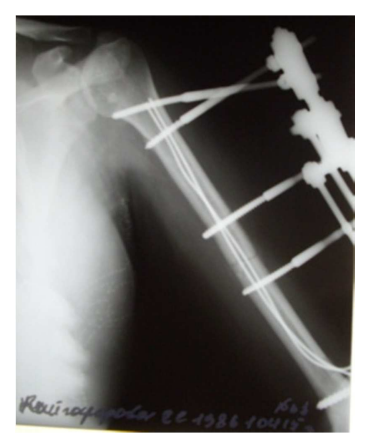

б

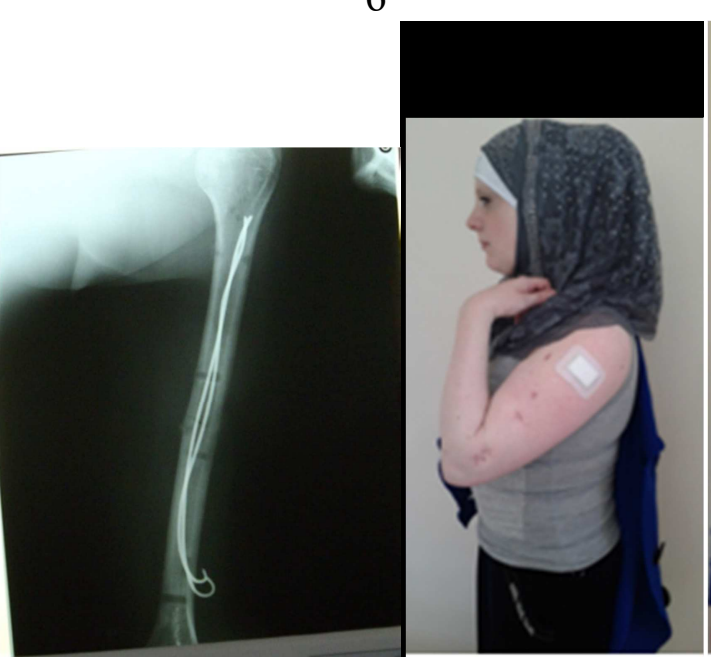

B

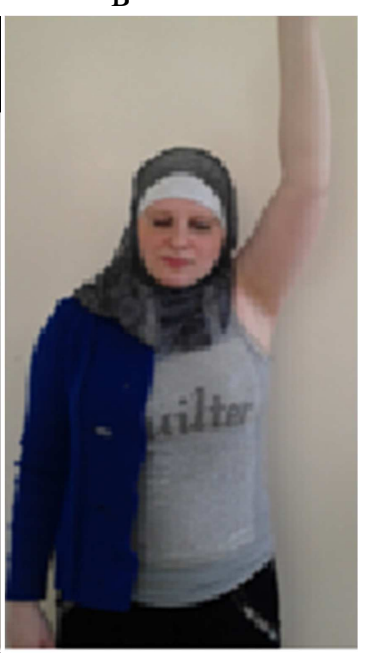


Рис. 4.28. Больная К., 28 лет. Диагноз - закрытый диафизарный перелом левого плеча: рентгенограмма левого плеча до лечения (а), после комбинированного остеосинтеза монолатеральным аппаратом(б), врентгенограммы плеча через месяц после операции (аппарат демонтирован), д-е рентгенограммы плеча и фото больного через месяц после демонтажа аппарата (функция смежных суставов).

Через месяц амбулаторного лечения аппарат был демонтирован (рис. 4.28в), а еще через месяц контрольный осмотр позволил констатировать полное функциональное восстановление пациентки (рис. 4.28 д,е).

Таким образом, наш опыт использования комбинированного остеосинтеза при закрытых переломах диафиза плечевой кости позволяет утверждать, что технология интрамедуллярного остеосинтеза спицами с биоактивным покрытием гидроксиапатитом высокоэффективна и позволяет резко сократить сроки остеосинтеза аппаратом внешней фиксации. Консолидация костных отломков при комбинированном сотеосинтезе наступает не позднее 6 недель даже в пожилом возрасте на фоне остеопороза. Первые рентгенологические признаки репаративной регенерации в зоне перелома плеча отчетливо видны в среднем через 3 недели и в этот срок возможен демонтаж АВФ с дополнительной иммобилизацией плеча ортезом на срок 2-3 недели. Остеосинтез плеча аппаратом наружной фиксации можно легко ограничить монолатеральной конструкцией, что значительно повышает комфортность самообслуживания пациентов.

\section{6. Остеосинтез диафизарных переломов костей предплечья}

По некоторым данным, среди всех повреждений костей переломы костей предплечья занимают по частоте второе место после переломов костей голени. По данным разных авторов частота переломов костей предплечья колеблется от $28 \%$ до 53\% [Молодцов А.Н., Родионов А, Б, 2001; Oskam J, J Kingma, H J Klasen , 1998].

Сложности в лечении переломов костей предплечья связаны прежде всего с функциональными особенностями ближайших суставов и руки в целом. Особые трудности при лечении переломов предплечья возникают при их локализации в области диафиза. При таких переломах костные фрагменты обычно смещаются по длине, ширине и под углом, что значительно затрудняет процесс их репозиции и удержания, учитывая малый диаметр костей [Каплан А.В. 1979]. Все эти сложности определяют и количество возможных осложнения при лечении переломов, несмотря на вековой опыт развития консервативного метода и многообразие оперативных методов лечения. Количество осложнений и неудовлетворительных исходов достаточно велико и достигает 31-70 \% даже у детей [ Меркулов В.Н., Дорохин А.И, 2001; Khosla et al., 2003;- Luhmann SJ,et al., 2004]. 
Консервативный метод лечения заключается в закрытой репозиции с применением различных приемов и наложении гипсовой повязки. Прогноз результата лечения определяется возрастом пациента, характером перелома, качеством исполнения репозиции и наложения гипсовой повязки, сроком фиксации и адекватной реабилитацией. Консервативный метод отличается относительной простотой исполнения, дешевизной, доступностью материалов, хорошо переносится детьми, при этом наибольшая эффективность его применения наблюдается у детей младшего возраста (до 6-7 лет). [Czerny F, et al., 1994]. К преимуществам метода также можно отнести отсутствие рисков оперативного вмешательства.

Однако консервативный метод имеет свои недостатки: велика вероятность вторичного смещения костных отломков, ограничение использования при открытых переломах, риски возникновения фликтен, развития компартмент синдрома, иммобилизация смежных суставов и развитие после этого контрактур, необходимость в реабилитации после снятия гипсовой повязки [Bowman EN, et al. 2011; Franklin CC, Wren T, Ferkel E, Arkader A. 2014]. Поэтому в последние десятилетия наметилась тенденция к использованию внутренней фиксации при травмах этой локализации, как правило, у детей старшего возраста и взрослых [Агаджанян В.В., 2003; Иванников С. с соавт., 2003; Кривенко, С.Н., 2010; Capo J.T. et al.2009; Yung S. H., Lam C. Y. 1998; ModrzewsKi K., Urban T. 2000].

На сегодняшний день травматологи применяют следующие методы оперативного лечения: открытый интрамедуллярный остеосинтез ригидными стержнями, накостный остеосинтез пластинами, остеосинтез аппаратами наружной фиксации, интрамедуллярный эластичный стабильный остеосинтез.

Накостный остеосинтез имеет целый ряд преимуществ: позволяет стабильно зафиксировать отломки в правильном положении на весь период консолидации, не требует внешней иммобилизации, при этом возможна ранняя полная функция, во время выполнения оперативного вмешательства нет необходимости использования Сдуги, применение пластин. Общеизвестны и недостатки метода, связанные с необходимостью широкого обнажения зоны перелома, скелетированием костных отломков и связанным с этим нарушением кровоснабжения кости, что увеличивает риск несращения, интра- и послеоперационных осложнений. Видимо это и объясняет, что при накостном остеосинтезе частота несращений варьирует от 2,3\% до 4 \%, частота рефрактур после удаления пластин - от 1,9\% до 30,4\%. Частота инфекционных осложнений при данной методике составляет от $0,8 \%$ до $4,7 \%$, также высок риск неврологических расстройств в результате повреждения лучевого и срединного 
нервов, что может привести к нарушению функции кисти. Наконец, протяженный послеоперационный рубец неэстетичен [Lascombes P. 2006.].

Чрескостный остеосинтез аппаратом Илизарова позволяет успешно преодолевать все трудности выполнения точной репозиции отломков, их стабильной фиксации и поддержании исходных размеров межкостной мембраны предплечья [Иванников, С. С соавт., 2003; Быков В.М., Ковшова М.Ф., Горшенина О.В. ,2001]. Он может применяться при переломах костей предплечья, сопровождающихся повреждением мягких тканей, в том числе открытых и огнестрельных, фрагментарных, оскольчатых и многооскольчатых; ситуациях, когда пациенту противопоказано выполнение внутреннего остеосинтеза; при различных последствиях переломов. Однако к недостаткам аппаратов внешней фиксации при переломах диафиза костей предплечья можно отнести громоздкость аппаратов и сложность монтажа, длительность остеосинтеза, а также функциональные ограничения, связанные с необходимостью прошивания спицами многочисленных мышц и фиксации радио-ульнарных сочленений. К недостаткам также можно отнести необходимость постоянного квалифицированного врачебного наблюдения на протяжении всего периода фиксации аппаратом [Девятов А.А.,1990].

Осложнениями метода чрескостного остеосинтеза являются: поверхностное воспаление в местах «прорезывания» спицами мягких тканей, глубокое воспаление, спицевой остеомиелит, вторичное смещение, переломы и деформации на уровне костной мозоли после снятия аппарата, контрактуры смежных суставов, асептическая резорбция кости вокруг спиц, предрасполагающая ко вторичным смещениям отломков, инфекционным и геморрагическим осложнениям, болевому синдрому. Суммарнаят частота подобных осложнений достигает, по данным различных авторов $8-27 \%$.

Открытый интрамедуллярный остеосинтез ригидными стержнями имеет значительные ограничения анатомического характера и редко используется у детей [Bowman EN, Mehlman CT, Lindsell CJ, Tamai J. 2011; Sinikumpu JJ, Serlo W. 2015 ].

В противовес ему в травматологии появились идеи, получившие название: “менее инвазивный”, “минимально инвазивный” или “биологический” внутренний остеосинтез [ModrzewsKi K., Urban T., 2000; Goodwin RC, Kuivila TE., 2002]. Реализация данной концепции возможна при использовании метода закрытого Интрамедуллярного Эластичного Стабильного Остеосинтеза (ИЭСО). Первое сообщение о лечение перелома костей предплечья у детей и подростков опубликовано испанскими ортопедами Perez-Sicilia J.E., Morote Jurado J.L. at all. в 1977г. Дальнейшее 
разностороннее развитие метода связано с университетской клиникой города Nancy (Франция), в которой благодаря работам Métaizeau J.P., Lascombes P., Ligier, Prévot J. и других метод получил научное обоснование и на сегодняшний день по мнению многих авторов является «золотым стандартом» при лечении диафизарных переломов костей предплечья у детей. Преимуществом ИЭСО, по сравнению с прочими хирургическими методами, является малоинвазивность - установка эластичного стержня производится внеочагово через разрез не более 2-3 см, вне зоны роста и сосудисто-нервных образований; стабильная эластичная фиксация дает возможность избежать дополнительной иммобилизации и обеспечивает раннюю полную функцию, включая ротационные движения; низкий риск возможных осложнений. Также немаловажное значение имеют высокий косметический результат, короткий стационарный период, быстрое возвращение к повседневной жизни детей и удовлетворенность родителей. Наличие биоактивного покрытия внутрикостного эластичного имплантата в виде гидроксиапатита повышает скорость консолидации костных фрагментов.

К сожалению данный метод не нашел самостоятельного применения у взрослых больных, однако объединив его с аппаратом внешней фиксации можно легко преодолеть все сложности в репозиции и удержании отломков на то короткое время, которое необходимо для консолидации костных фрагментов даже у взрослых пациентов. Мы назвали данный метод остеосинтеза комбинированным остеосинтезом АВФ с интрамедуллярным армированием спицами, имеющими биоактивное покрытие. Клинический пример. Пациент М., 14 лет поступил в первые сутки после травмы с диагнозом: Закрытый перелом костей левого предплечья в средней трети диафиза (рис.4.29a).

Сосудистых и неврологических расстройств выявлено не было. Механизм травмы - падение с упором на левую руку с высоты собственного роста. Через 1 час после поступления под общей анестезией произведена попытка закрытой ручной репозиции отломков костей предплечья с последующей фиксацией гипсовой лонгетой и иммобилизации смежных суставов предплечья. Удовлетворительной репозиции добиться не удалось, что явилось показанием для оперативного вмешательства по методике закрытого ИЭСО. Диаметр имплантатов - 2,5 мм. Во время операции имплантаты введены в кости из кожных проколов 1,5 см : в лучевую кость ретроградно через дистальный метафиз, а в локтевую антеградно через проксимальный метафиз (рис.4.29б). Время операции составило 35 минут. Ранний послеоперационный период протекал без осложнений. На рентгенограммах на второй 
день после остеосинтеза: положение отломков удовлетворительное, физиологическая пронационная дуга лучевой кости восстановлена, расположение имплантатов не изменилось .

Возможность к самообслуживанию восстановилась на 8 сутки (рис. 4.29в). Швы сняты на 9 сутки после остеосинтеза. Стационарный срок лечения составил 10 суток.
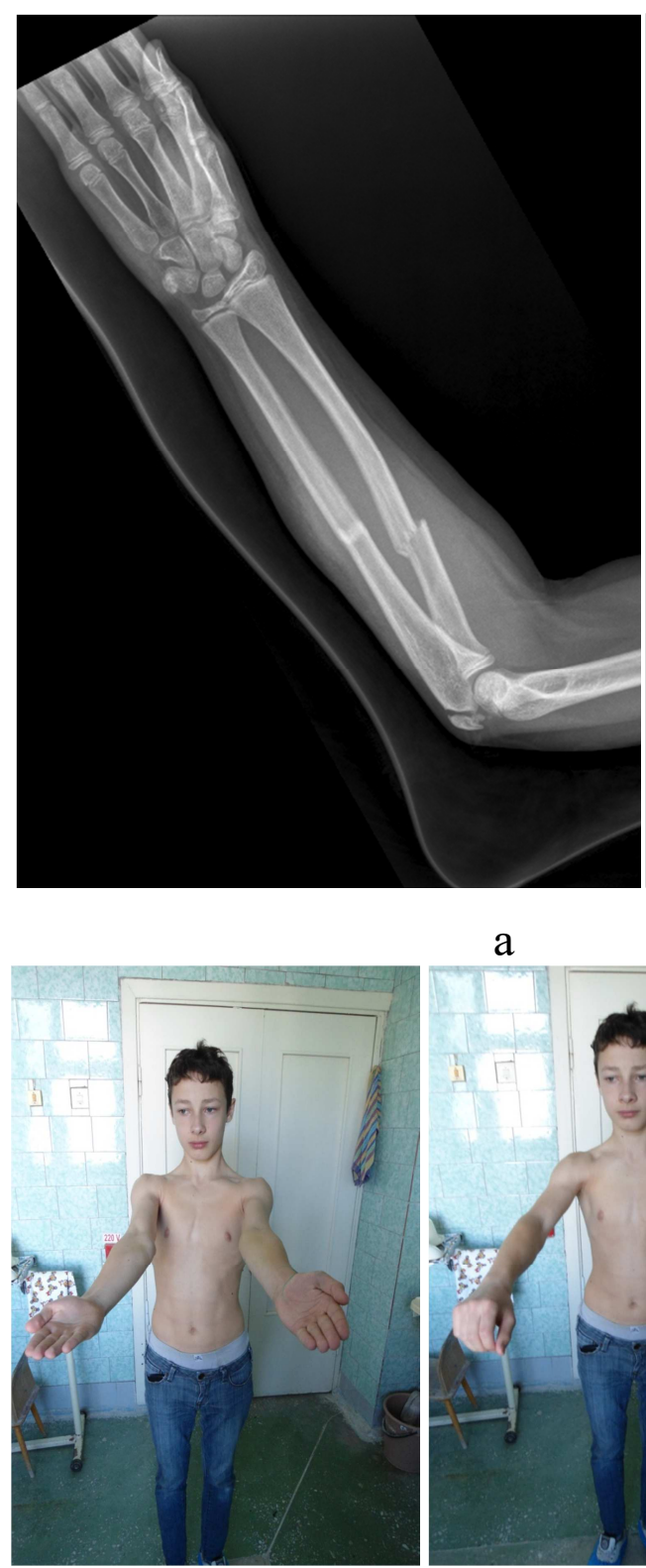

$\mathrm{a}$
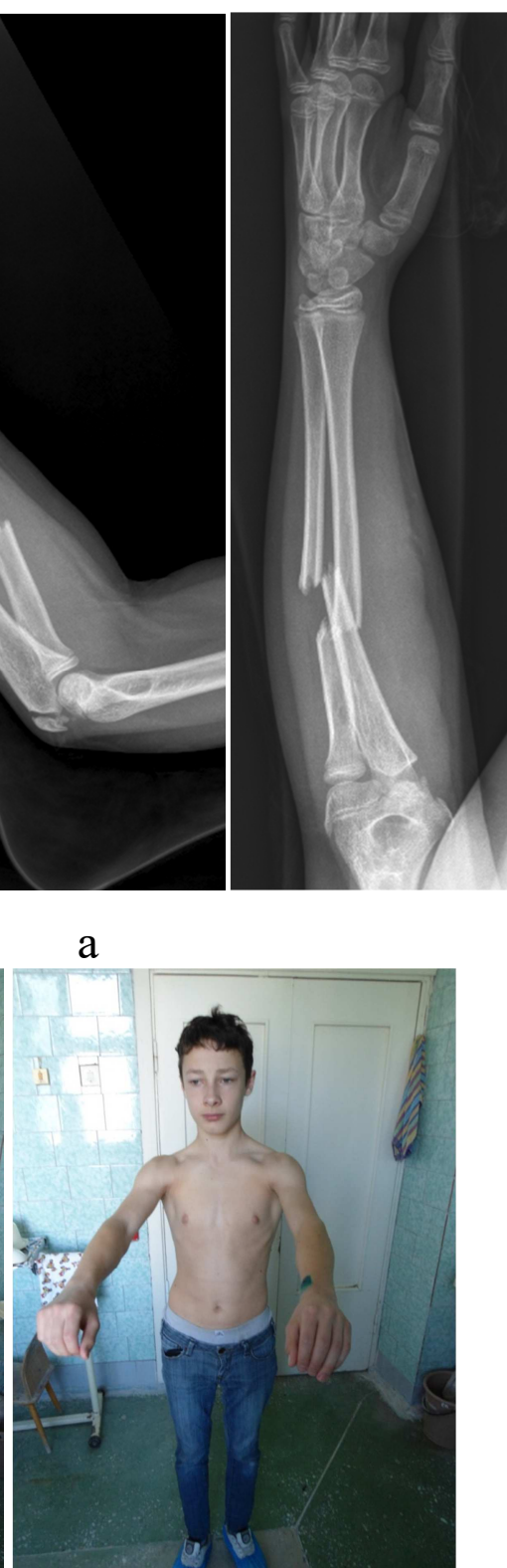

B

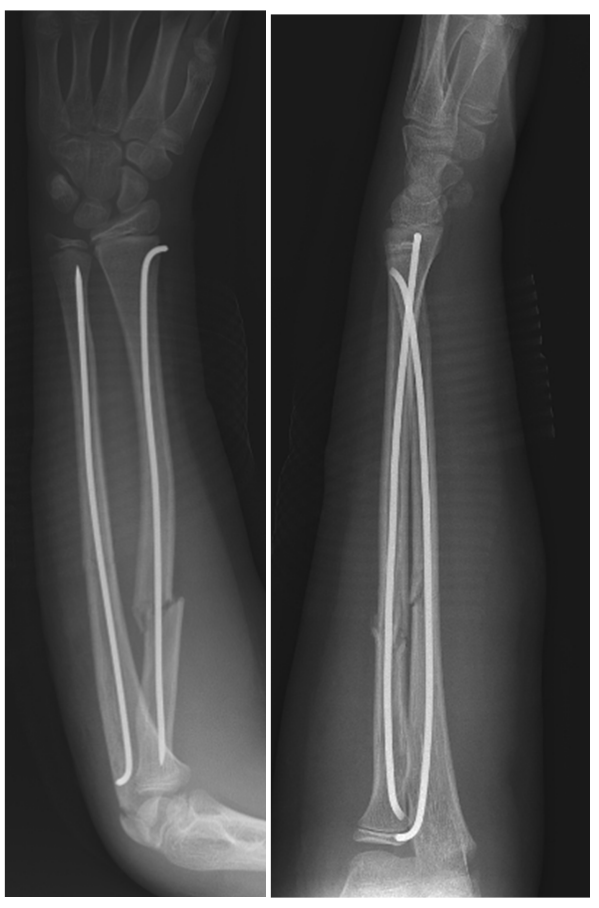

6 


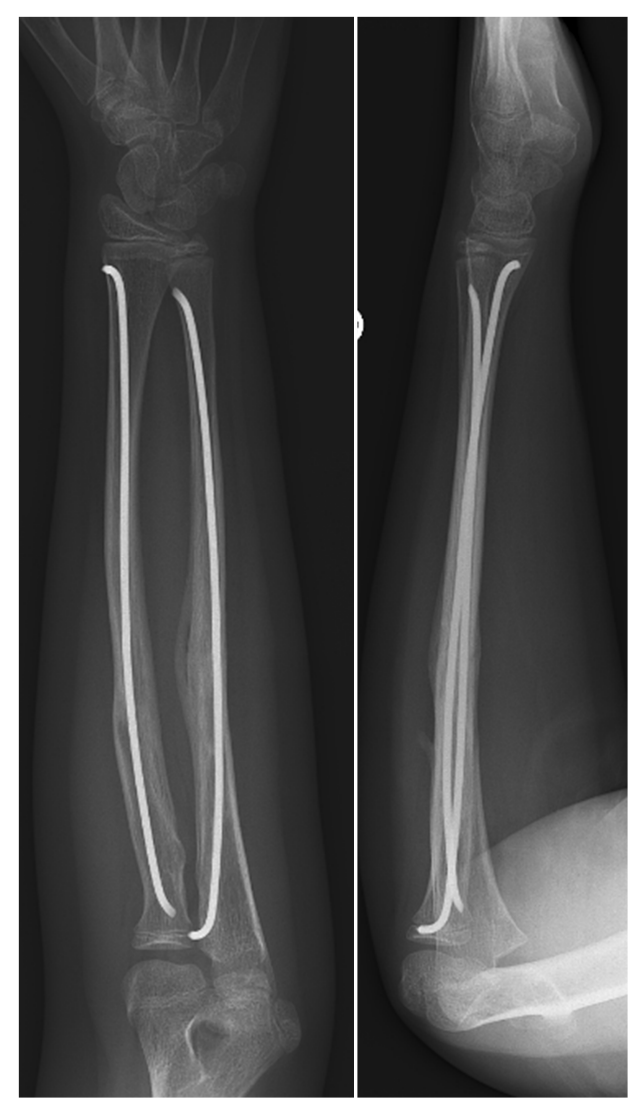

$\Gamma$

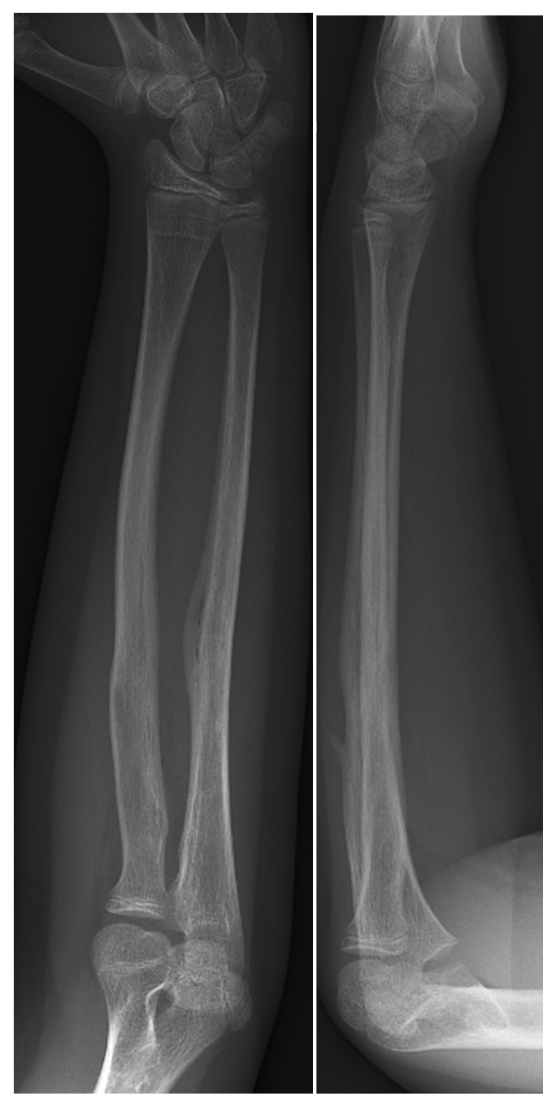

Д
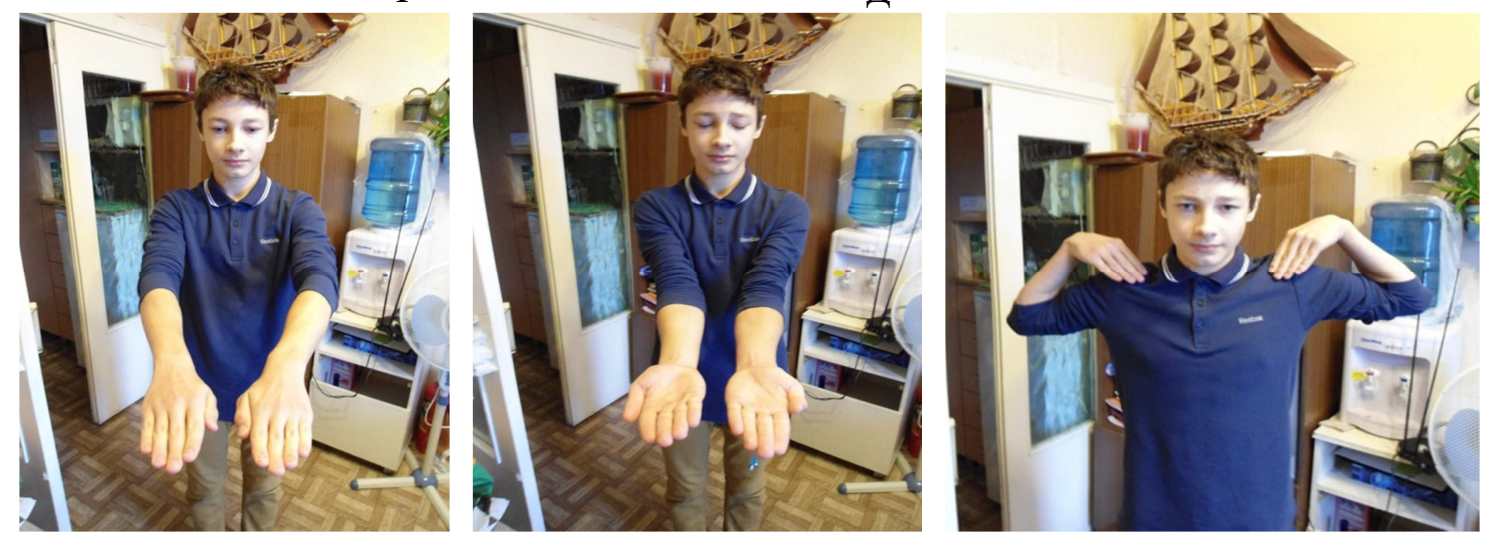

$\mathrm{e}$

Рис. 4.29. больного М., 14 лет: а - рентгенограммы предплечья при поступлении; б - рентгенограммы предплечья после остеосинтеза; в - функция предплечья через 10 дней после операции; г - рентгенограммы предплечья через месяц после операции; д - рентгенограммы предплечья через 6 месяцев после остеосинтеза (имплантаты удалены); - ф функция предплечья восстановлена полностью.

К занятиям в школе пациент приступил сразу после выписки с освобождением от физкультуры. При осмотре через 1 месяц после остеосинтеза жалоб не предъявлял, наступило полное функциональное восстановление поврежденного предплечья (рис.4.29г).

На консультации через 6 месяцев после операции отмечена полная функциональная реабилитация пациента (рис.4.29e), констатирована консолидация перелома и интрамедуллярные имплантаты удалены под общей анестезией (рис.4.29д).

Клинический пример. Больной Н.,20 лет. Д-з: Закрытый перелом диафиза правой лучевой кости (Рис.4.30 а). 
Операция: Комбинированный чрескостный остеосинтез аппаратом Илизарова с интрамедуллярным армированием спицей с ГА покрытием. Первые рентгенологические признаки репаративной регенерации отмечены через 19 дней после операции. Аппарат демонтирован через 45 дней фиксации в амбулаторных условиях. Удалили интрамедуллярную спицу через 1,5 месяца после снятия аппарата.

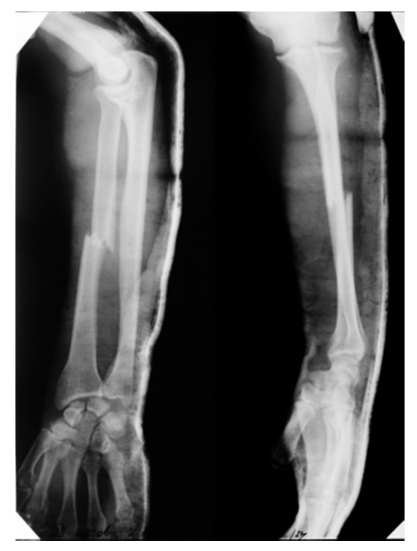

a

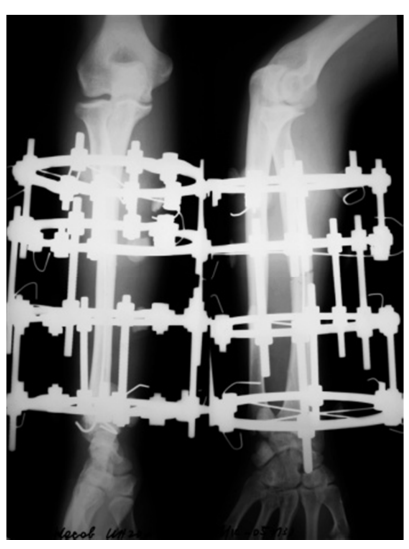

6

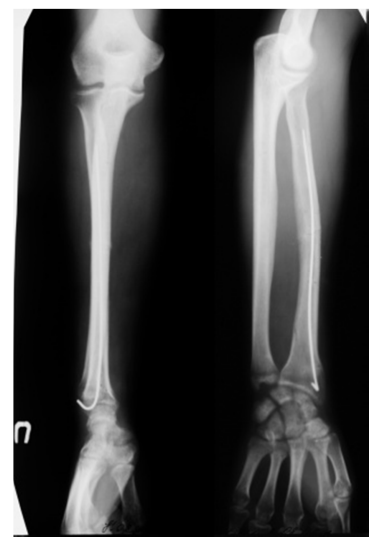

B

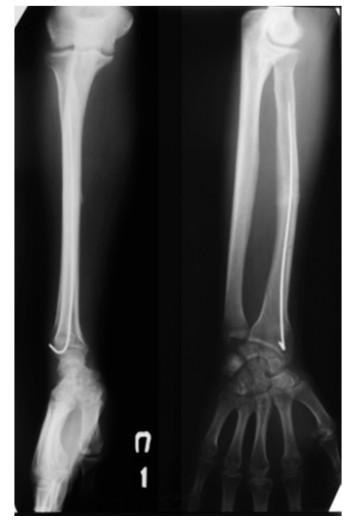

$\Gamma$

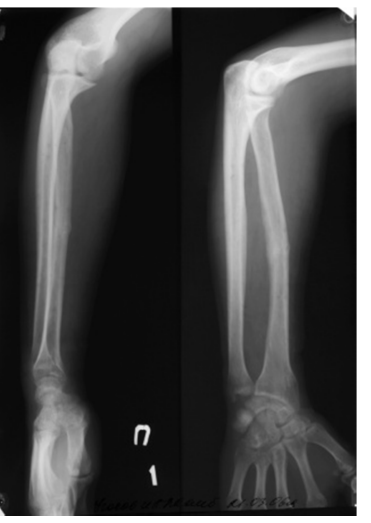

Д

Рис. 4.30. Рентгенограммы предплечья пациента Н., 20 лет: а - закрытый перелом лучевой кости; б - в день операции; в - через 45 дней после операции (аппарат Илизарова демонтирован);г - через месяц после демонтажа аппарата; д - через 1,5 месяца (интрамедуллярная спица удалена) - полная консолидация.

Клинический пример. Больная Г., 48 лет. Диагноз: Закрытый перелом дистальной трети диафиза левой локтевой кости. Травма бытовая (Рис. 4.31a).

Операция - 5.10.2005 - Комбинированный остеосинтез аппаратом Илизарова и интрамедуллярной спицей с ГА покрытием (Рис.4.31б).

Через 28 дней появились первые рентгенологические признаки репаративной регенерации в зоне контакта костных фрагментов (Рис.4.31в). Аппарат Илизарова снят через 45 дней (Рис.4.31г). Наступила консолидация, амортизации при клинической пробе не выявлено. Контрольный осмотр через 3 месяца показал полное функциональное восстановление и консолидацию костных фрагментов (Рис.4.31д). 


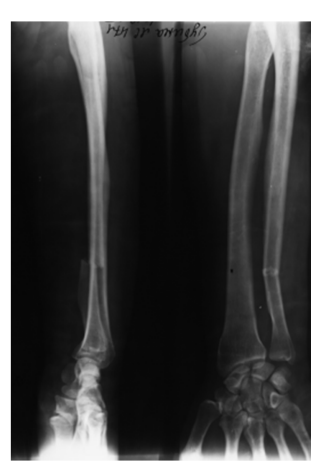

a

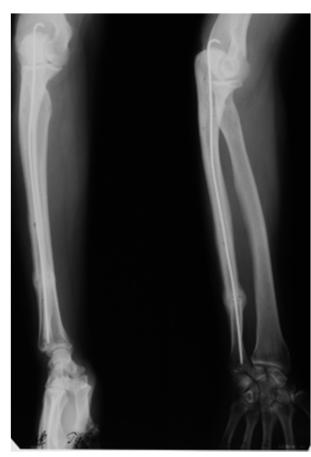

Д

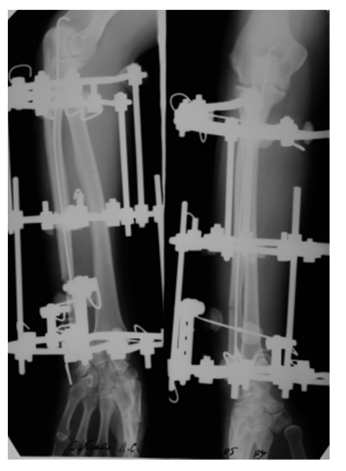

6

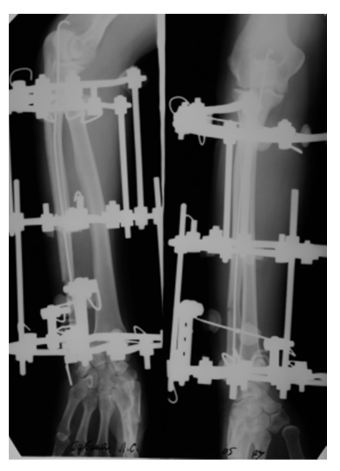

B

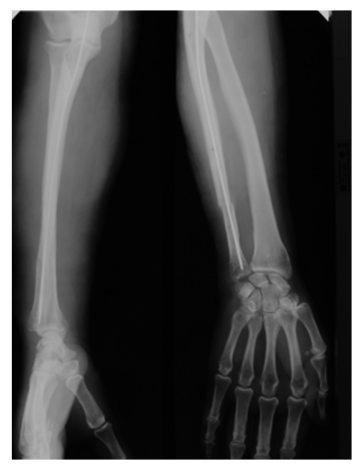

$\Gamma$

Рис. 4.31. Рентгенограммы костей предплечья больной Г., 48 лет. Диагноз: Закрытый перелом диафиза левой локтевой кости: а - до операции, б - в день операции. В - через 28 дней после операции, г - в день демонтажа аппарата Илизарова, д - через 3 месяца после демонтажа аппарата Илизарова.

Очевидным преимуществом метода является его функциональность: уже через 7-10 дней после операции восстанавливалась возможность самообслуживания. Восстановление амплитуды движений в смежных суставах, пронационно-супинационных движений происходило на протяжении 1-2 месяцев после операции.

Рентгенологически консолидация костных отломков предплечья наступает в течение месяца даже у взрослых пациентов. В это время следует демонтировать аппарат Илизарова, тем более, если сломана одна из костей. Однако амбулаторная форма лечения не всегда позволяет осуществить это ввиду чисто организационных причин: отсутствие в районной больнице травматолога и невозможность пациента вовремя приехать в областной центр. 


\section{ГЛАВА 5.}

\section{ИНТРАМЕДУЛЛЯРНОЕ АРМИРОВАНИЕ ПРИ ЗАМЕДЛЕННОЙ КОНСОЛИДАЦИИ, ЛОЖНЫХ СУСТАВАХ И ДЕФЕКТАХ ДЛИННЫХ ТРУБЧАТЫХ КОСТЕЙ}

Проблему травматизма мы частично затронули в предыдущей главе и убедились, что в России повышение инвалидизации пострадавших достигло такого уровня, когда следует предлагать новые методы лечения и реабилитации, способные гарантировать положительный результат в короткие сроки.

По данным Федерального бюро медико-социальной экспертизы, только в 2009 г. численность впервые признанных инвалидами лиц от 18 лет и старше с последствиями травм опорно-двигательного аппарата составила 138454 человека, а повторно признано инвалидами 407 035. Среди детей (до 17 лет включительно) с последствиями травм впервые признано инвалидами 1832 ребенка и повторно - 719. Если учесть только этих пострадавших, более полумиллиона инвалидов после травм ожидает немедленной помощи, а государство несет огромные экономические потери, которые могли бы обернуться дополнительно выпущенной продукцией и принести материальную прибыль как государству, так и непосредственным участникам производительного труда. Повторим, что экономические потери от инвалидности составляют 129586 рублей на одного впервые признанного инвалидом от травм и их последствий и 25529 рублей на одного инвалида, сохраняющего инвалидность после переосвидетельствования. Легко подсчитать, что ежегодно государство выплачивает порядка 30 млрд рублей на пособия по инвалидности.

В данной главе мы представляем некоторые медицинские технологии лечения последствий травм (случаи замедленной консолидации, ложных суставов, дефектов длинных трубчатых костей, в том числе и осложненных остеомиелитом). Более 50 \% среди инвалидов от травм составляют пострадавшие с переломами костей конечностей. При этом доминирующее положение занимают травмы бедра и голени [Устьянцев В.И., 2006], подтверждая тем самым не только их тяжесть, но и определенную несостоятельность существующих методов лечения и реабилитации, а также организационных форм системы медицинской помощи [Цыбуляк Г.Н., 1994; Журавлев С.М., 1997; Ахметьянов Р.Ф., 2005; Гришина Л.П., 2005; Щепин О.П., Тищук Е.А., 2005]. Только хронический остеомиелит развивается в 21-46\% случаев после оперативного лечения открытых и в 7,6-13,2\% - закрытых переломов современными общепринятыми технологиями. 
Еще недавно существовало мнение, что псевдоартрозы необходимо лечить открытыми хирургическими методами с применением металлоостеосинтеза, костной аутопластики, микрохирургической техники. Однако неудовлетворительные исходы лечения при замещении дефектов длинных трубчатых костей свободными алло- и аутотрансплантатами обусловлены отсутствием полноценного внутрикостного кровообращения [Лаврищева Г.И., Оноприенко Г.А., 1996; Hernigou P., Beaujean F., 2002]. Использование кровоснабжаемых свободных аутотрансплантатов всегда было травматичным оперативным вмешательством, а до эпохи Илизарова их фиксация была проблематичной и не обеспечивала полностью условия для репаративного процесса [Голубев В.Г. и др., 1989; Гришин И.Г. и др., 2001; Тu Y.K. et al., 2001]. В результате высокий процент неудовлетворительных исходов лечения, связанный с тромбозом артериовенозных шунтов, отторжением, нагноением и переломами массивных костных трансплантатов [Богов А.А., Плаксейчук А.Ю., 1993; Гришин И.Г. и др., 2001; Mathoulin C. et al., 1993].

Изучая организацию, средства и способы восстановительного лечения в современной травматологии и ортопедии, мы пришли к выводу и глубокому убеждению в том, что наиболее эффективны в лечении ложных суставов и дефектов костей методики чрескостного остеосинтеза, разработанные в РНЦ «ВТО» им. акад. Г.А. Илизарова и основанные на атравматичности оперативного вмешательства, стабильности фиксации, дозированном напряжении формообразовательных процессов, полноценном кровоснабжении и функциональной нагрузке. При лечении такой сложной патологии, как замедленная консолидация, ложные суставы и посттравматические дефекты длинных костей, проявляются в полной мере достоинства и преимущества чрескостного остеосинтеза, ибо именно для этого в абсолютном большинстве случаев во всем мире применяются аппараты внешней фиксации. Метод чрескостного остеосинтеза обеспечивает необходимую в этих случаях стабильную фиксацию отломков, плотный контакт на стыке фрагментов кости, независимо от их формы, сохранение опорнодинамической функции конечности в процессе лечения, что делает его незаменимым при лечении нарушений консолидации и позволяет избежать ампутации [Гражданов К.А. с соавт., 2010; Соломин, Л.Н., 2005; Уразгильдеев, З.И. с соавт., 2002; Karapinar, H. et al., 2010]. Необходимыми условиями успешного выполнения столь сложных вмешательств являются достаточная квалификация и опыт оперирующей бригады.

Высоко оценивая результаты восстановления целостности конечности у пациентов с дефектами костей, замещенными по методу Илизарова, большинство авторов единственным, но существенным недостатком считает длительный срок чрескостного 
остеосинтеза [Шапошников Ю.Г. и др., 1990; Плаксейчук А.Ю., 1994; Голяховский В., Френкель B., 1999; Paley D., Maar D.C., 2000; Tripon P. et al., 2000; Gulsen M. et al., 2001]. Время консолидации составляет в среднем от 3 до 11 месяцев. Продолжительность органотипической перестройки дистракционного регенерата в первую очередь зависит от его размера и возрастает соответственно величине удлинения отломка [Барабаш А.П., 1995; Макушин В.Д. и др., 1995; Catagni М.А., 1999]. При одноуровневом удлинении большеберцовой кости индекс остеосинтеза составляет 44,3 \pm 3,6 дня/см [Борзунов Д.Ю., 2004]. Значительная продолжительность остеосинтеза аппаратоми внешней фиксации является причиной развития наиболее часто встречающегося осложнения чрескостного остеосинтеза - гнойно-воспалительных процессов, развивающихся в мягких тканях и костях вокруг спиц и стержней (10-46\%). Но они довольно успешно купируются при своевременной местной и общей противовоспалительной терапии и в большинстве случаев не влияют на окончательный результат лечения [Девятов, А.А., 1990; Викторова, Н.Л. , 1995; Р.М. Эринле, А.В. Рак, С.А. Линник,Г.П. Салдун, 1996; Bassiony, А.А. et al., 2009; Karapinar, H. et al., 2010].

Поиск способов лечения, направленных на сокращение сроков остеосинтеза, в настоящее время реализуется в появлении новых технологий, основанных на применении методик многоуровневого удлинения фрагментов кости и стимуляции репаративного остеогенеза с помощью биоактивных интрамедуллярных имплантатов, позволяющих гарантировать положительный результат лечения ложных суставов и дефектов длинных трубчатых костей в очень короткие сроки.

Показания к использованию медицинской технологии. Технология показана при лечении больных с псевдоартрозами и дефектами длинных трубчатых костей верхних и нижних конечностей. Остеосинтез осуществляют в плановом порядке.

Данная технология лечения предусматривает фиксацию пораженного сегмента аппаратом чрескостного остеосинтеза, введение в костномозговой канал и через зону ложного сустава спиц, имеющих биоактивное покрытие их ГА, остеотомию костного фрагмента, нуждающегося в удлинении, дозированную тракцию фрагментов до восстановления необходимой длины и оси сегмента и последующую стабильную фиксацию сегмента до консолидации кости.

Резекцию ложного сустава осуществляют далеко не всегда. Тугой ложный сустав без угловых деформаций кости является показанием для закрытого остеосинтеза конечности аппаратом Илизарова с интрамедуллярным армированием спицами, имеющими биоактивное ГА-покрытие. Интрамедуллярные имплантаты с кальций-фосфатным покрытием, изготовленным по нанотехнологиям, обеспечивают стимуляцию 
репаративного остеогенеза как на этапе формирования костного регенерата, так и в ходе его перестройки в костную ткань, способную выдерживать статико-динамическую нагрузку.

Противопоказания к использованию медицинской технологии. Абсолютными противопоказаниями к применению технологии лечения больных с псевдоартрозами и дефектами костей конечностей являются соматические заболевания, исключающие возможность проведения ортопедических операций, тяжелые психические расстройства. Временными противопоказаниями служат инфекционное поражение тканей сегментов конечностей и смежных суставов, острый период остеомиелита. Как показал наш опыт, хронический остеомиелит не является противопоказанием для данного метода оперативного лечения.

\section{1. Общие принципы интрамедуллярного остеосинтеза}

В ближайшем к планируемой остеотомии метафизе удлиняемой кости с помощью специальной фрезы) диаметром 5 мм через предварительно выполненные проколы мягких тканей в кортикальном слое формируют сообщающееся с костномозговым каналом наклонное отверстие ( рис.4.1) .

В это отверстие вводят специальный трубчатый направитель (рис. 5.1), который
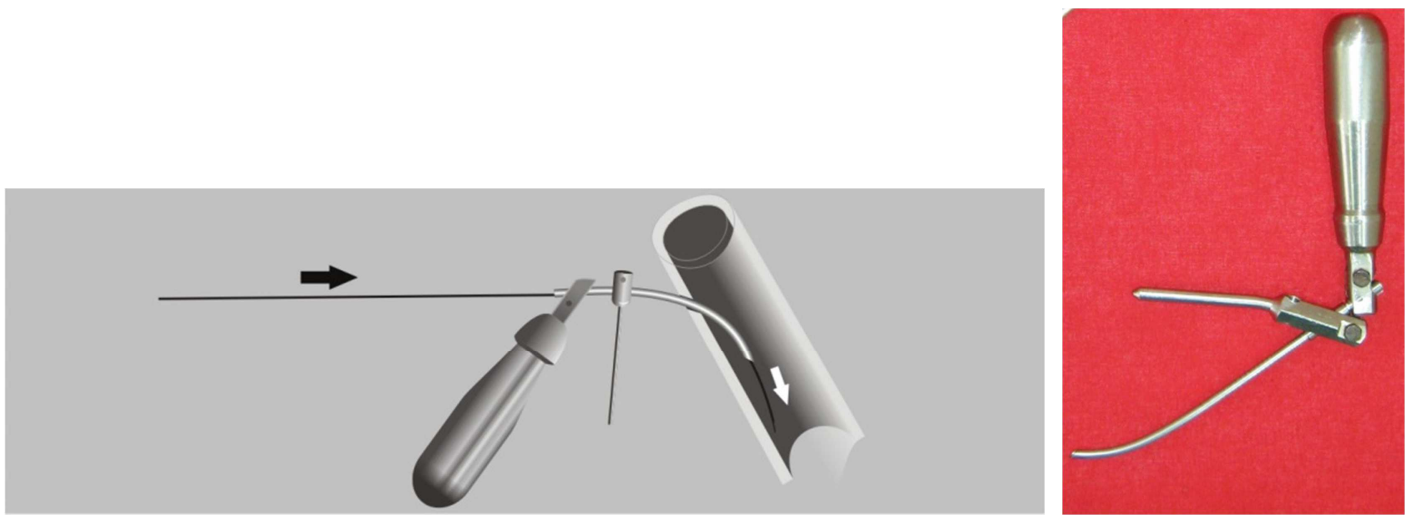

Рис. 5.1. Схема расположения трубчатого направителя в кости (спица расположена в канале направителя) и фотография инструмента.

определяет и строго поддерживает выверенное направление введения спицы в соответствии с формой костномозгового канала и деформации кости. Последнее очень важно, так как именно при лечении данной категории больных приходится рассверливать кость этой же спицей при эбурнеации костномозгового канала и через ложный сустав.

Через направитель в костномозговой канал вводят спицу с кальций-фосфатным покрытием. Как правило, костномозговой канал после многочисленных предшествующих операций на большей части своей протяженности выполнен костными перегородками, поэтому мы рекомендуем для интрамедуллярного армирования использовать спицы с 
перьевой или даже копьевидной заточкой, которые достаточно легко рассверливают костные преграды в костномозговом канале и запирательные пластинки в зоне ложного сустава (если это необходимо). Спица обычно рассверливает для себя канал вплоть до противоположного метафиза кости. После того как направитель удаляют из канала, избыток длины спицы скусывают, а ее конец загибают и погружают под фасцию сегмента конечности.

После введения интрамедуллярных спиц мягкие ткани ушивают наглухо и осуществляют чрескостный остеосинтез поврежденного сегмента конечности аппаратом Илизарова в той комплектации, которая соответствует поставленной перед хирургом задаче.

Технология чрескостного остеосинтеза и монтаж аппарата Илизарова мало чем отличаются от того, что было неоднократно описано сотрудниками РНЦ «ВТО» им. акад. Г.А. Илизарова и утверждено МЗ РФ. Мы чаще используем спице-стержневую комплектацию аппарата, особенно при остеосинтезе бедра, тем самым обеспечивая максимальный комфорт для пациента во время лечения в амбулаторных условиях и надежный стабильный остеосинтез костных фрагментов.

Наличие в костномозговом канале спиц с биоактивным покрытием не мешает проведению спиц аппарата Илизарова через поперечник кости.

Удаление интрамедуллярных спиц желательно осуществлять не ранее чем через 6 месяцев после демонтажа аппарата Илизарова. Под местной анестезией или при внутривенном наркозе над местом введения спиц производят разрез кожи (5-8 мм), мягкие ткани тупо раздвигают и, захватив конец спицы крючком или специальными щипцами, вращательно-поступательными движениями извлекают ее из костномозгового канала.

В случае значительного сопротивления спицы следует воспользоваться дозированным ударным механизмом, который навинчивают на шило-крючок ( рис. 4.3).

Возможные осложнения и способы их устранения. Осложнений, связанных с интрамедуллярным введением спиц, мы не наблюдали. Встречавшиеся трудности при их удалении назвать осложнениями нельзя ввиду того, что дополнительный специальный инструмент, разработанный нами, позволяет с ними справляться.

Все осложнения, наблюдавшиеся нам в клинической практике, связаны с основным методом чрескостного дистракционного остеосинтеза и отражают особенности того аппарата внешней фиксации, который использовали (аппарат Илизарова).

В целом следует отметить, что возможные осложнения носят, как правило, единичный характер, устранимы непосредственно в ходе остеосинтеза и не оказывают существенного 
влияния на результаты лечения. Их профилактикой служит точное соблюдение методических требований и техники выполнения остеосинтеза на каждом из этапов лечения. Относительно малое число осложнений мы связываем со значительным сокращением срока остеосинтеза (особенно периода фиксации аппаратом внешней фиксации).

Из многочисленных способов чрескостного остеосинтеза, используемых для лечения больных с ложными суставами и дефектами длинных трубчатых костей, мы рекомендуем:

• монолокальный компрессионный остеосинтез;

• билокальный комбинированный компрессионно-дистракционный остеосинтез;

• билокальный последовательный дистракционно-компрессионный остеосинтез.

При наличии псевдоартроза или дефекта кости, осложненного хроническим остеомиелитом, эти методики осуществляют при обязательной резекции очага хронического воспаления. Интрамедуллярное армирование через зону ложного сустава в таком случае возможно, если хирург уверен в полной ликвидации очага воспаления. Когда уверенности нет, то армирование следует отложить на 2 недели и ограничиться только внеочаговым остеосинтезом аппаратом Илизарова.

\section{2. Монолокальный комбинированный компрессионный остеосинтез}

Данная методика показана при наличии псевдоартроза длинной трубчатой кости, когда перед хирургом не стоит задача наряду с ликвидацией ложного сустава восстановить длину поврежденного сегмента конечности (рис. 5.2).

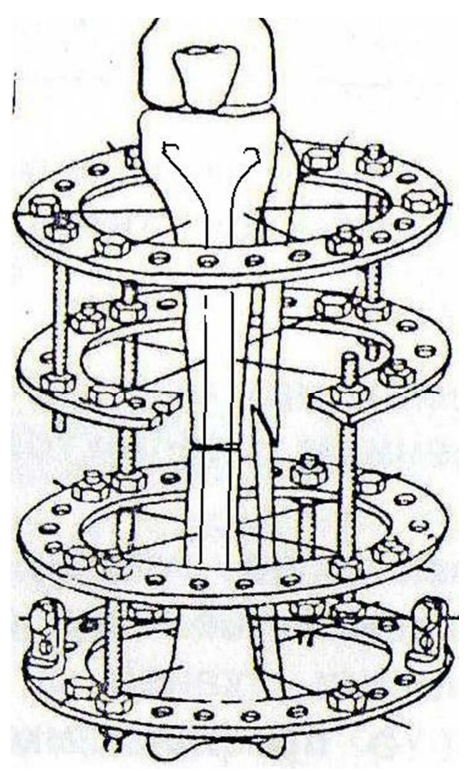

Рис. 5.2. Принципиальная схема монолокального компрессионного остеосинтеза с интрамедуллярным армированием спицами на примере лечения псевдоартроза голени. 
Операцию начинают с введения интрамедуллярных спиц, которые под контролем электронно-оптического преобразователя (ЭОП) засверливают до уровня запирательных кортикальных пластинок.

Затем осуществляют резекцию псевдоартроза с удалением всех некротизированных и свободно лежащих фрагментов, секвестров и инфицированных тканей. Форма резецированного участка и его величина во многом зависят от характера и величины деформации кости на уровне псевдоартроза. Задача, стоящая перед хирургом, - по возможности одномоментно восстановить ось сегмента конечности и конгруэнтность контактирующих поверхностей. После этого интрамедуллярные спицы вводят через зону ложного сустава в противоположный фрагмент кости. Обычно двух спиц достаточно для сохранения оптимального положения костных фрагментов до того как будет полностью завершен остеосинтез конечности аппаратом Илизарова.

После визуального, а при необходимости и рентгенологического контроля положения костных фрагментов рану ушивают наглухо, создается необходимая степень компрессии.

Клинический пример. Пациент М., 42 лет. Диагноз: посттравматический псевдоартроз и укорочение левого бедра на 4 см.

В результате многооскольчатого перелома бедра и многократных попыток оперативного лечения с использованием накостного и внутрикостного остеосинтеза сформировался ложный сустав в нижней трети бедра с угловой деформацией, укорочением конечности и стойкой разгибательной контрактурой коленного сустава (рис. 5.3 a).

Ввиду того, что у пациента имелась стойкая контрактура коленного сустава, вопрос об удлинении конечности не поднимался.

Операция: удаление сломанного внутрикостного фиксатора, резекция ложного сустава для исправления деформации, монолокальный компрессионный остеосинтез бедра с интрамедуллярным армированием спицами, имеющими ГА-покрытие (рис. 5.3 6, в).

Больной лечился амбулаторно. Через 1,5 месяца после операции он мог ходить без дополнительных средств опоры, однако, учитывая крайне неблагоприятные условия для репаративной регенерации (контрактура сустава, многочисленные рубцы, выраженный склероз концов костных фрагментов и разрушенный костный мозг), мы решили не рисковать и продолжили фиксацию аппаратом Илизарова до 3-х месяцев, после чего он был демонтирован (рис. 5.3 г). 

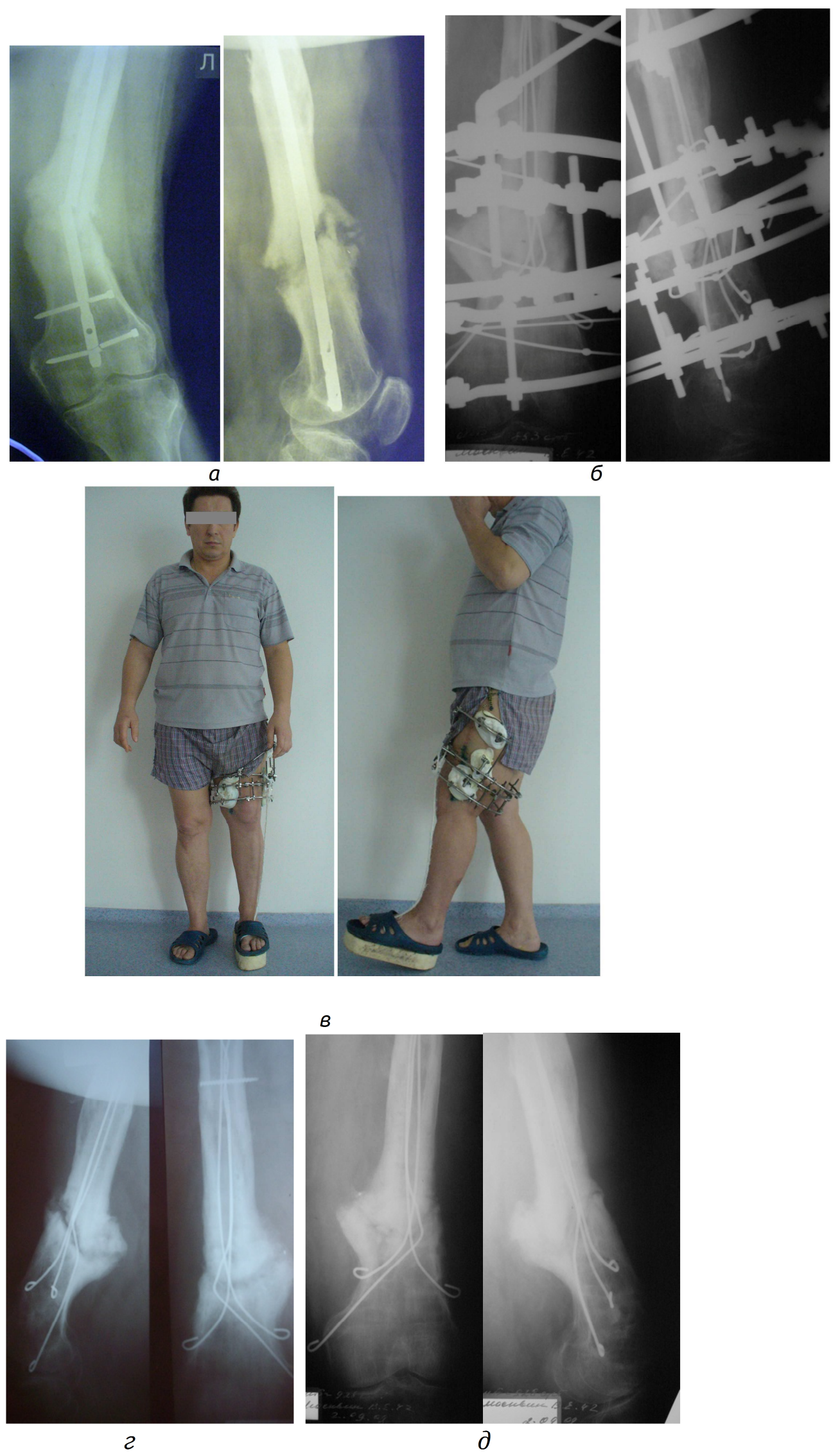


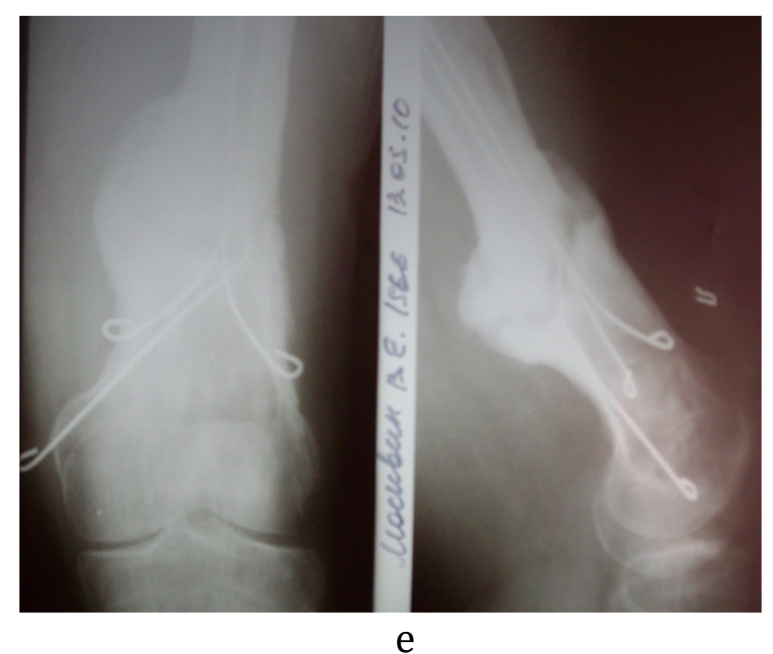

Рис. 5.3 . Пациент М., 50 лет: а — рентгенограммы бедра до лечения; б - рентгенограммы бедра после операции; в - внешний вид и функция нижней конечности в процессе остеосинтеза; г - pентгенограммы бедра в день демонтажа аппарата Илизарова; д - рентгенограммы бедра через 3 месяца после демонтажа аппарата Илизарова; е - рентгенограммы бедра через 6 месяцев после демонтажа аппарата Илизарова.

После демонтажа аппарата клинически и рентгенологически определялась консолидация костных фрагментов, но на фоне остеосклероза отчетливо прослеживались границы бывшего псевдоартроза (рис. 5.3 г).

При контрольных осмотрах через 3 и 6 месяцев пациент ходил с полной нагрузкой на ногу, рентгенологически консолидация кости не вызывала сомнений (рис. 5.3 д, e).

Клинический пример. Пациентка Н., 25 лет. Диагноз: ложный сустав нижней трети левой плечевой кости.

Ложный сустав сформировался после неоднократных попыток оперативного лечения, в том числе с интрамедуллярным остеосинтезом и накостным остеосинтезом конструкциями с памятью формы (рис. $5.4 a$ ).

Операция: удаление металлических конструкций предыдущего оперативного вмешательства, экономная резекция ложного сустава, ретроградное интрамедуллярное армирование спицами с ГАпокрытием, чрескостный остеосинтез аппаратом Илизарова (рис. 5.4 б). 


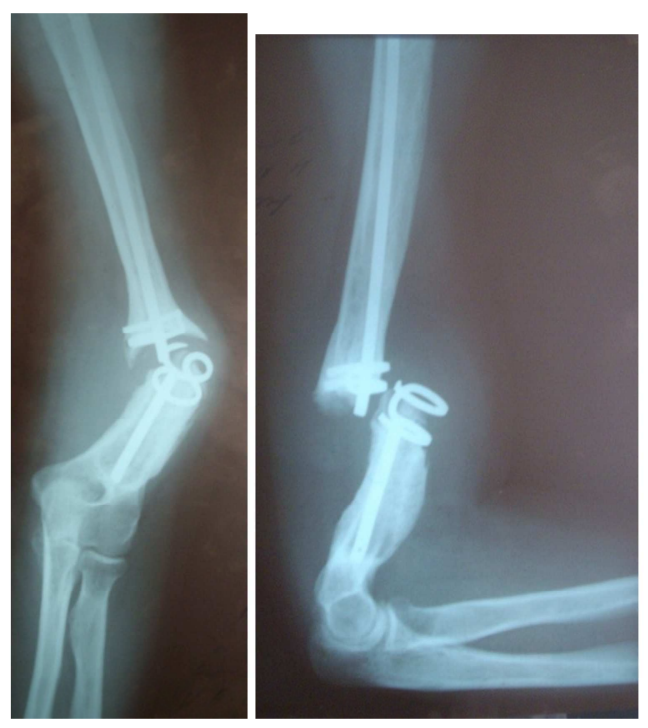

$a$

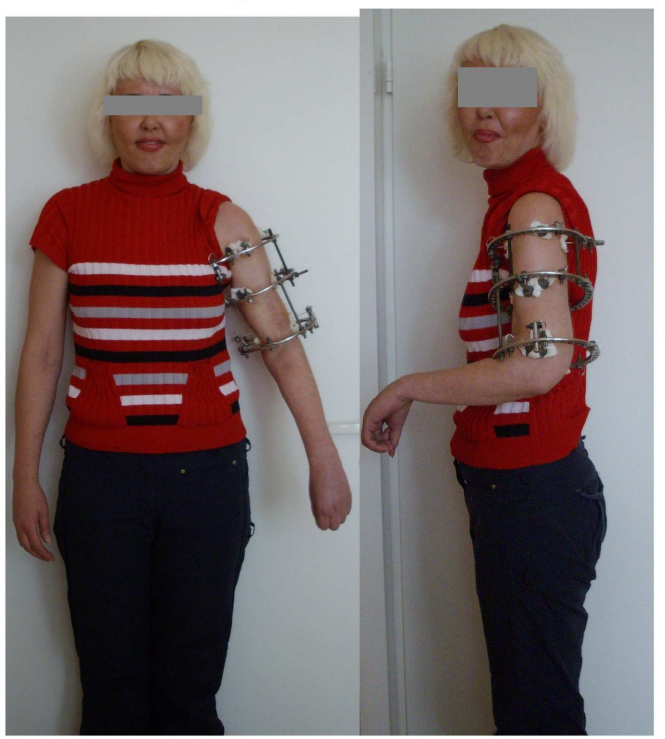

$B$

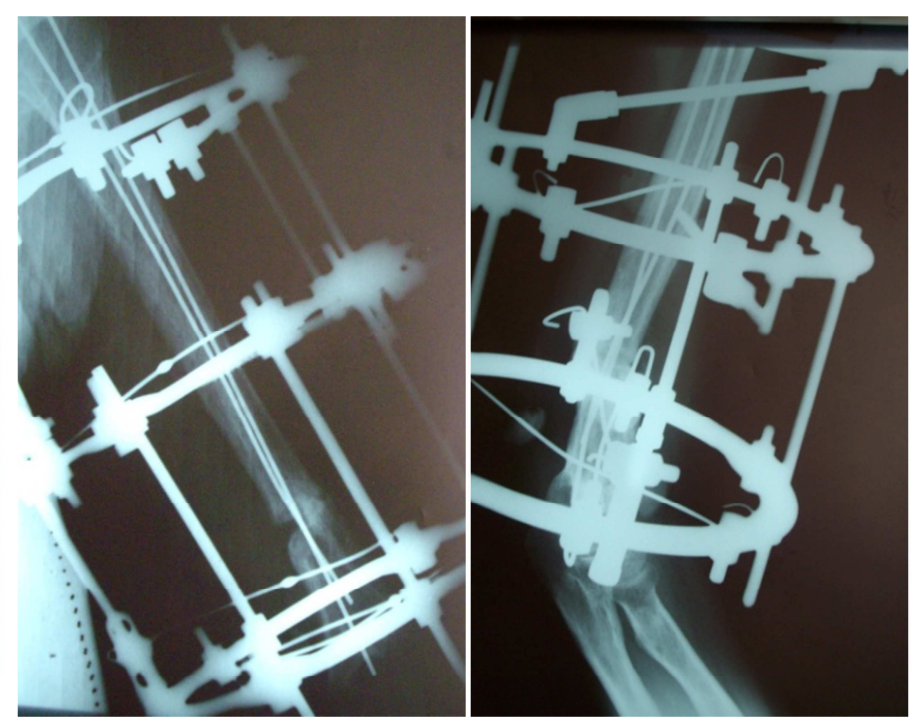

6
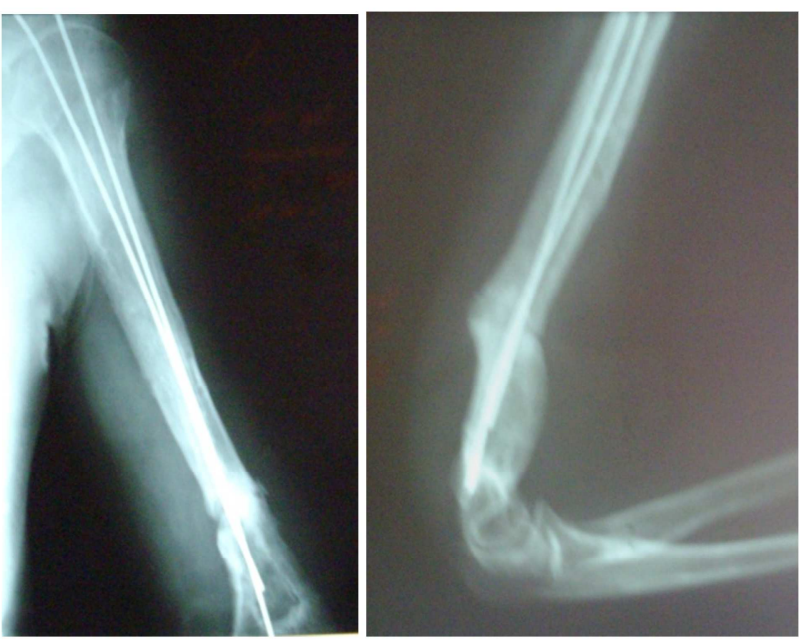

2

Рис. 5.4 . Пациентка Н., 25 лет: а — рентгенограммы плечевой кости до операции; б - рентгенограммы плечевой кости в процессе остеосинтеза; в - внешний вид в процессе остеосинтеза и функциональные возможности смежного сустава; г — рентгенограммы плечевой кости в день демонтажа аппарата Илизарова. 


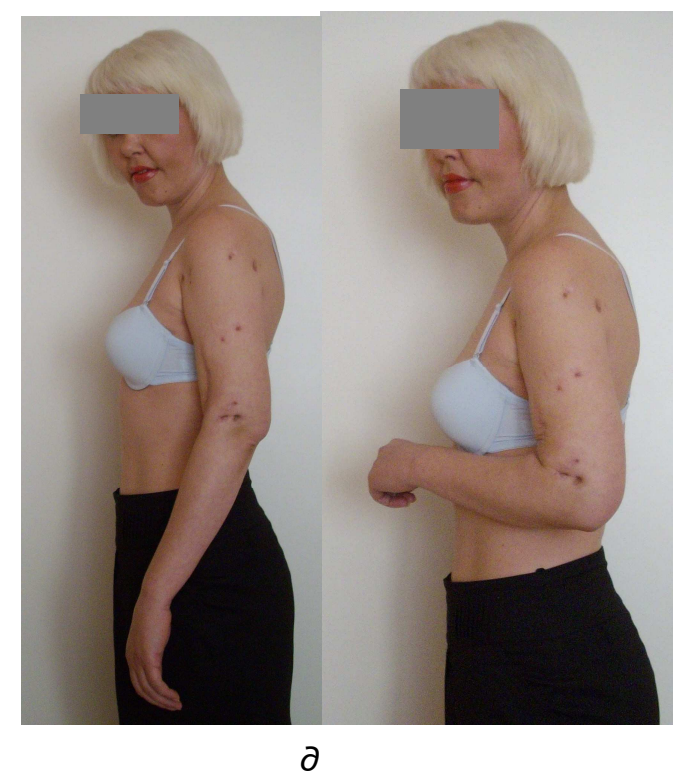

Рис. 5.4. (продолжение). Пациентка Н., 25 лет: д - внешний вид и функция верхней конечности через 1 месяц после демонтажа аппарата Илизарова.

Послеоперационный период протекал гладко, без каких-либо инфекционных осложнений. Система чрескостного остеосинтеза аппаратом Илизарова позволяла активно поддерживать амплитуду движений в локтевом суставе (рис. 5.4в).

Консолидация произошла через 2 месяца фиксации, и аппарат был демонтирован при отличном анатомическом и функциональном результате лечения (рис. 5.4 г, 2 ).

Клинический пример. Пациентка Ф., 32 лет. Диагноз: Посттравматический ложный сустав диафиза локтевой кости левого предплечья (рис. 5.5).

В 2008 году в результате ДТП наступил закрытый перелом локтевой кости. В г. Семипалатенске проводили оперативное лечение с фиксацией перелома спицей Киршнера. Консолидация не наступила. В 2013 году в г. Алма-Ата повторная операция костная пластика и накостный остеосинтез пластиной.

В феврале 2015 года почувствовала резкую боль в левом предплечье. По рентгенограмме диагносцировали перелом пластины и наличие ложного сустава. Обратилась в РНЦ «ВТО» им. академика Г.А.Илизарова для оперативного лечения.

Операция: Удаление накостной пластины, экономная резекция ложного сустава, комбинированный остеосинтез аппаратом Илизарова - интрамедуллярная спица с АГ покрытием.

Лечение амбулаторное. Аппарат Илизарова демонтирован через 3 месяца фиксации ввиду того, что гражданка другой страны не смогла раньше приехать на осмотр. Наступила консолидация. 


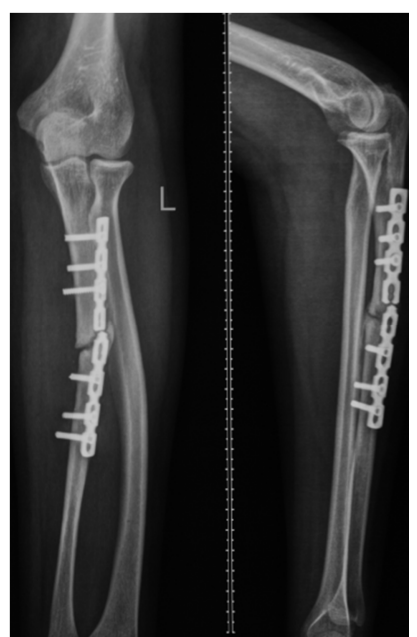

a

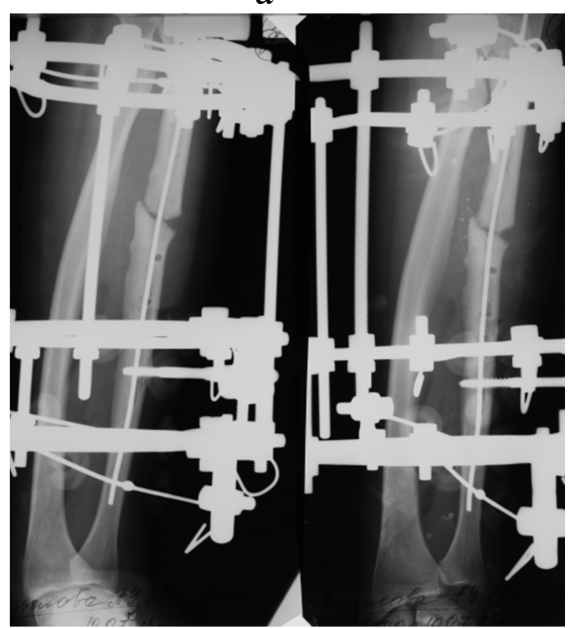

B
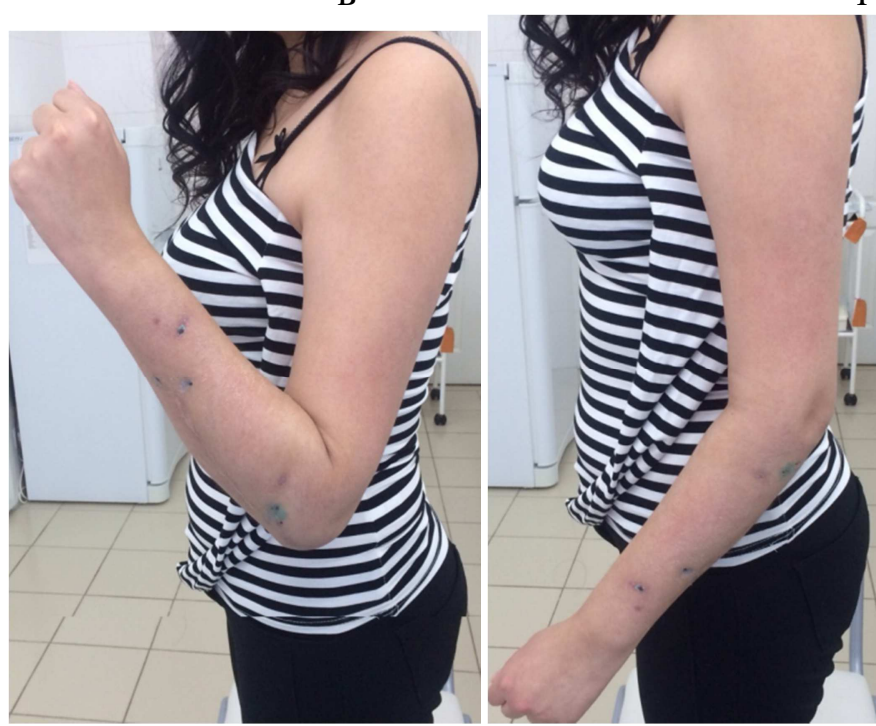

Д

$\Gamma$
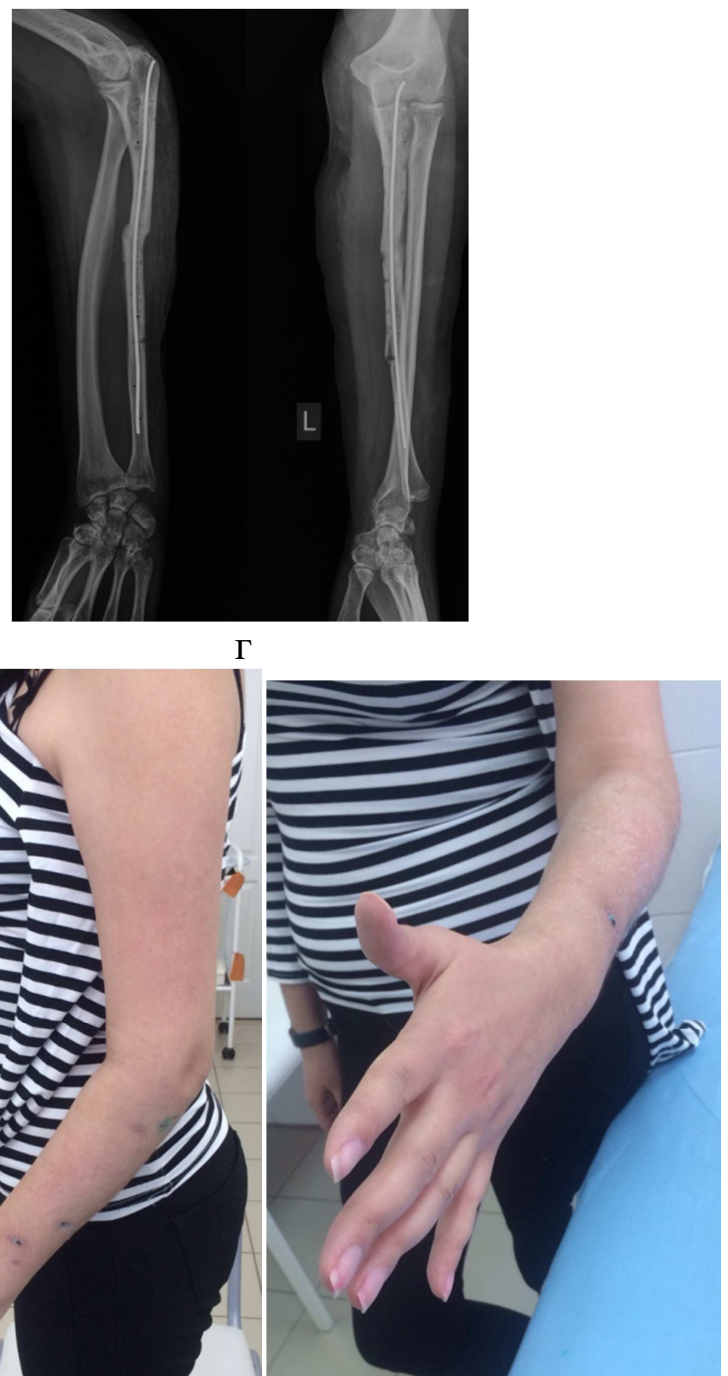

Рис.5.5. Пациентка Ф., 32 лет. Псевдоартроз сформировался после попытки оперативного лечения закрытого перелома локтевой кости накостной металлической конструкцией(a): б - фото больной до операции - отчетливо видна деформация левого предплечья; в - рентгенограммы левого предплечья в день операции; г - рентгенограммы левого предплечья в день демонтажа аппарата - наступила консолидация ложного сустава; д- фото больной после лечения - функция смежных суставов сохранены, ось конечности правильная. 
Клинический пример. Пациентка Д., 33 года. Диагноз: ложный сустав диафиза левой локтевой кости. Псевдоартроз сформировался после попытки оперативного лечения закрытого перелома локтевой кости накостной металлической конструкцией (Рис. 5.6а).

Операция: удаление накостной конструкции, монолокальный компрессионный остеосинтез локтевой кости аппаратом Илизарова, интрамедуллярный остеосинтез спицами с ГА-покрытием (рис. Рис. 5.6. б). Через 1,5 месяца амбулаторного лечения произошла консолидация локтевой кости (рис. Рис. 5.6.в), и аппарата Илизарова был демонтирован (рис. 17.3, г). После контрольного обследования через 2,5 месяца (рис. Рис. 5.6.d) были удалены интрамедуллярные спицы. Супинационнопронационные движения в суставе сохранены (рис. Рис. 5.6. е).

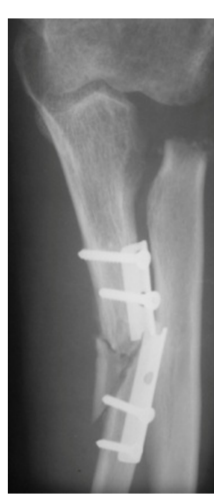

$a$

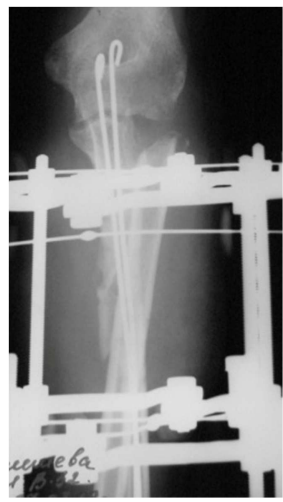

$\sigma$

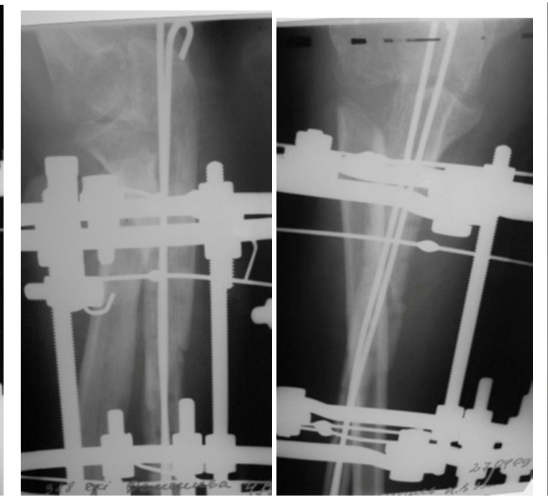

B

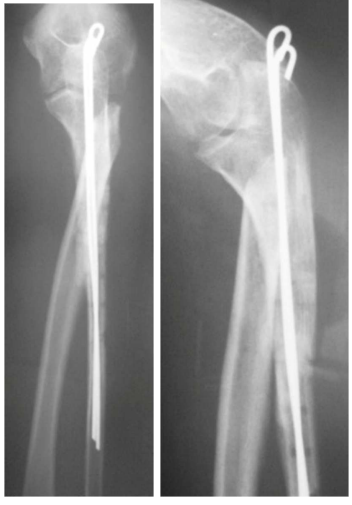

2
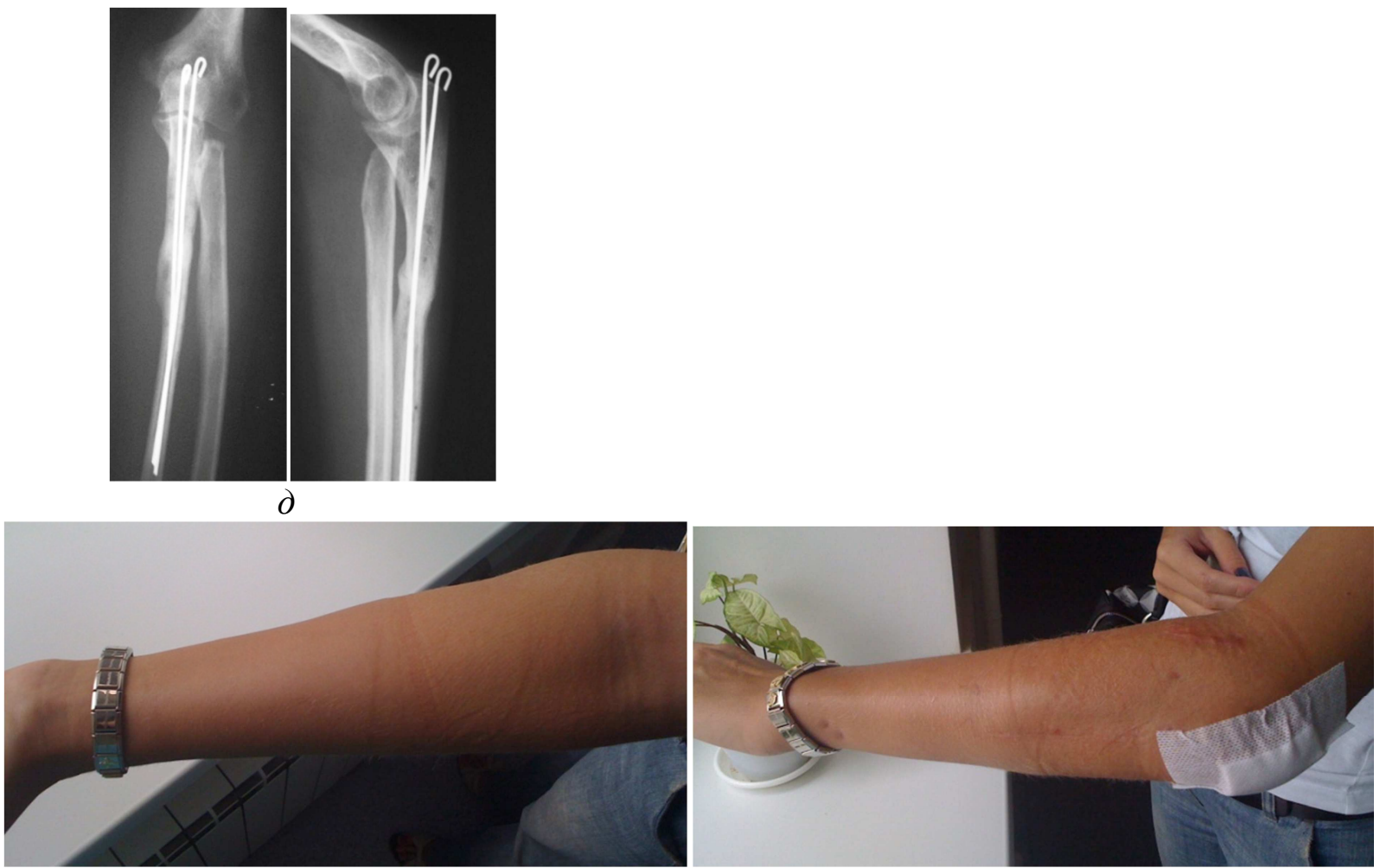

Рис. 5.6. Пациентка Д., 33 года: а - рентгенограмма костей предплечья до лечения; 6 - рентгенограмма костей предплечья в день операции; в - рентгенограмма костей предплечья через 1,5 месяца фиксации; г — рентгенограмма костей предплечья в день демонтажа аппарата Илизарова; д рентгенограммы костей предплечья через 2,5 месяца после демонтажа аппарата Илизарова; е функция верхней конечности в день удаления интрамедуллярных спиц. 
Клинический пример. Пациент П. ,45 лет (рис. 5.7). В анамнезе - ДТП. Сочетанная травма: закрытый перелом левого плеча, открытый двойной перелом костей левой голени, множественные переломы ребер, левосторонний пневмо-гидроторакс.

Лечился в г.Челябинске. Остеосинтез конечностей осуществлен через 2 недели после травмы, после восстановления функции жизненно важных органов.

Операция: 1.07.2014 -Интрамедуллярный остеосинтез большеберцовой кости, интрамедуллярный остеосинтез плечевой кости.

Консолидация левого плеча прошла без особенностей, а на голени констатировали замедленную консолидацию и проводимые мероприятия по стимуляции репаративного процесса (физиотерапия, динамизация остеосинтеза) в течение 10 месяцев результатов не давали. Констатация тренда в сторону формирования ложного сустава голени вынудила больного обратиться в Российский научный центр «Восстановительная травматология и ортопедия» им. академика Г.А.Илизарова (г.Курган) с направлением «Неконсолидированный перелом костей левой голени».

22.05.2015 года операция. Удаление интрамедуллярных стержней плеча и голени. Комбинированный остеосинтез левой голени интрамедуллярными спицами с ГА покрытием и монолатеральный стержневой аппарат ввиду того, что при клинической пробе определялась амортизирующая подвижность.

Фиксация в аппарате - 1 месяц.

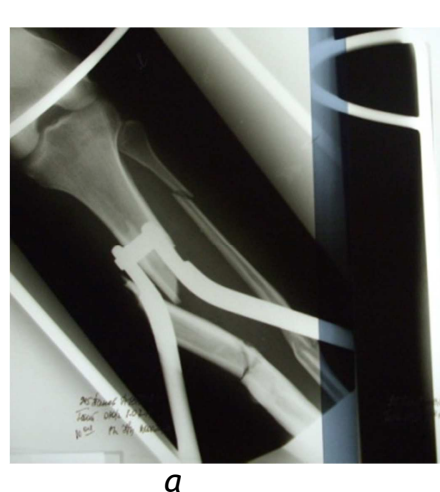

$a$
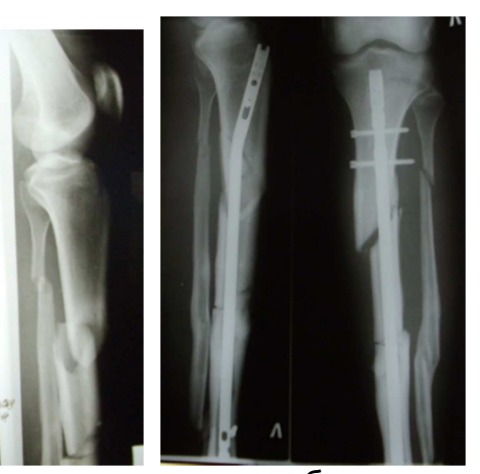

6

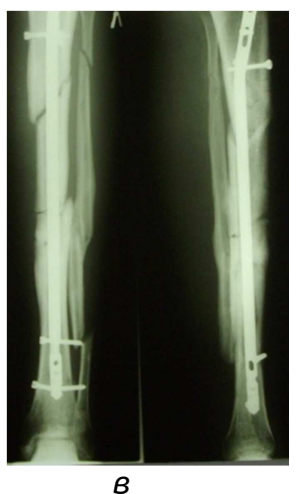

B 

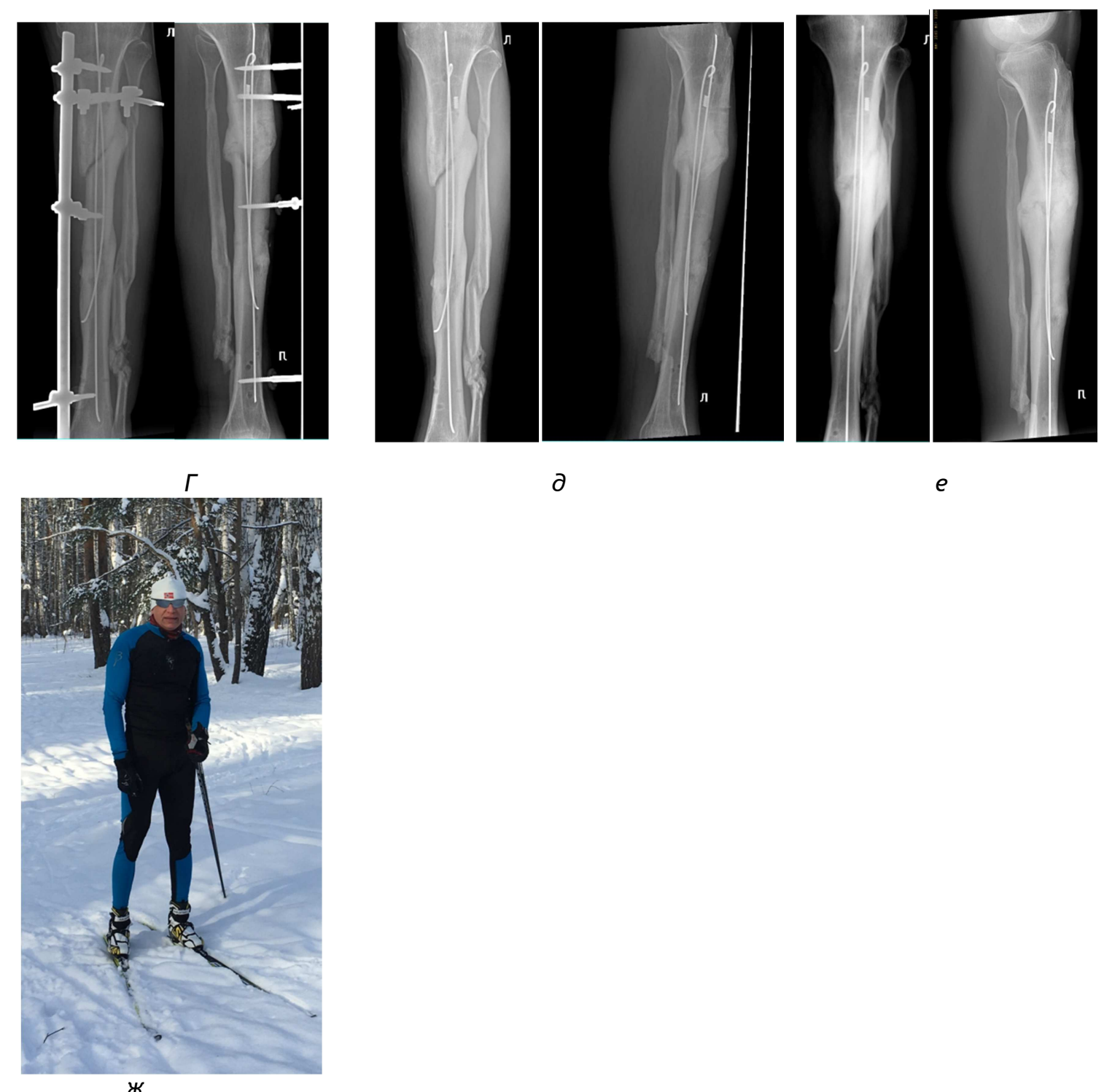

$\partial$

$e$

Рис. 5.7. Рентгенограммы левой голени больного П, 43 лет; а - в первые дни после травмы; б - остеосинтез интрамедуллярным блокирующим стержнем; в - через 10 месяцев после остеосинтеза стержнем(формируется ложный сустав верхней трети диафиза большеберцовой кости); г комбинированный остеосинтез интрамедуллярными спицами с ГА покрытием и монолатеральный стержневой аппарат (1 месяц фиксации); д -после демонтажа АВФ (наступила консолидация);е - десять месяцев после демонтажа АВФ; ж - пациент на лыжной прогулке через 2 месяца после демонтажа АВФ.

После демонтажа аппарата внешней фиксации дополнительная иммобилизация ортезом продолжалась месяц, больной ходил с постепенно возрастающей нагрузкой. Через месяц начал ходить без дополнительных средств опоры, а к Новому Году прислал лечащему врачу телеграмму, что уже дважды пробежал на лыжах по 20 км (Рис. 5.7ж)

Клинический пример. Пациент С., 38 лет.

Диагноз: закрытый перелом диафиза обеих костей левой голени со смещением (рис. 5.8a).

Операция: Закрытый остеосинтез левой голени аппаратом Илизарова (рис. 5.8б). Остеосинтез продолжался 5,5 месяцев в амбулаторных условиях, после чего 
рентгенологически и клинически диагностировано формирование ложного сустава большеберцовой кости (рис. 5.8в).

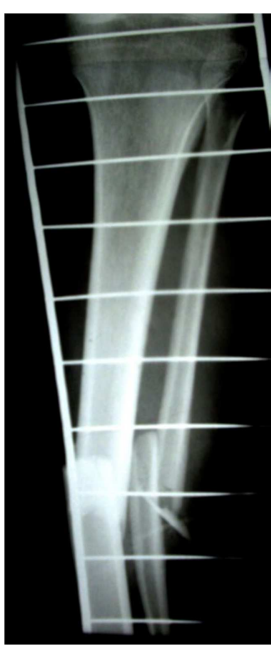

$a$

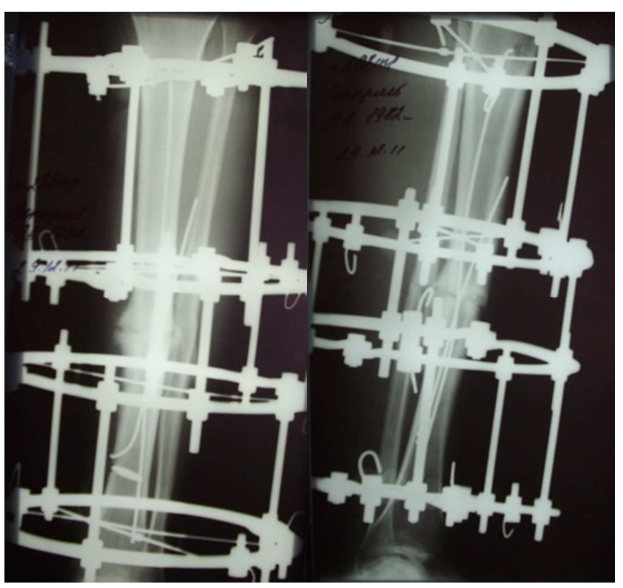

$\Gamma$

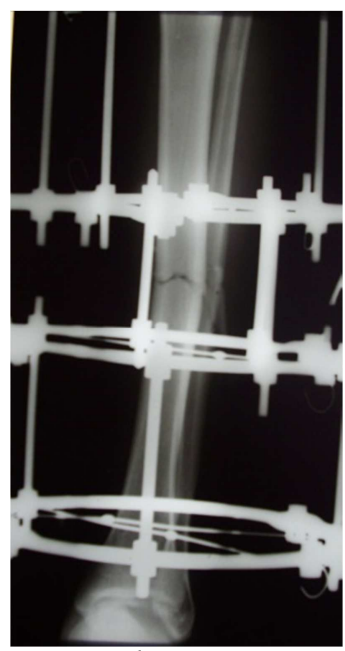

6

Рис. 5.8. Рентгенограммы левой голени больного С., 38 лет: а - в день травмы; б - после остеосинтеза аппаратом Илизарова; в - через 5 месяце после остеосинтеза аппаратом Илизарова (сформировался псевдоартроз);г- дополнительный интрамедуллярный остеосинтез спицами с ГА покрытием; д - через 1,5 месяца после интрамедуллярного остеосинтеза (наступила консолидация, аппарат снят); е - через 2 месяца после демонтажа аппарата.

С целью стимуляции репаративного остеогенеза осуществлен дополнительно интрамедуллярный остеосинтез спицами с ГА покрытием (рис. 5.8г), который продолжался до консолидации перелома (Рис. 5.8д), после чего аппарат Илизарова был демонтирован. При контрольном осмотре через 2 месяца констатировано сращение костных фрагментов, пациент ходит с полной нагрузкой на травмированную ногу (рис. $5.8 \mathrm{e})$.

\section{3. Билокальный комбинированный компрессионно-дистракционный остеосинтез}

Методика показана при необходимости восстановления длины поврежденного сегмента конечности до 3 см (рис. 5.9). 


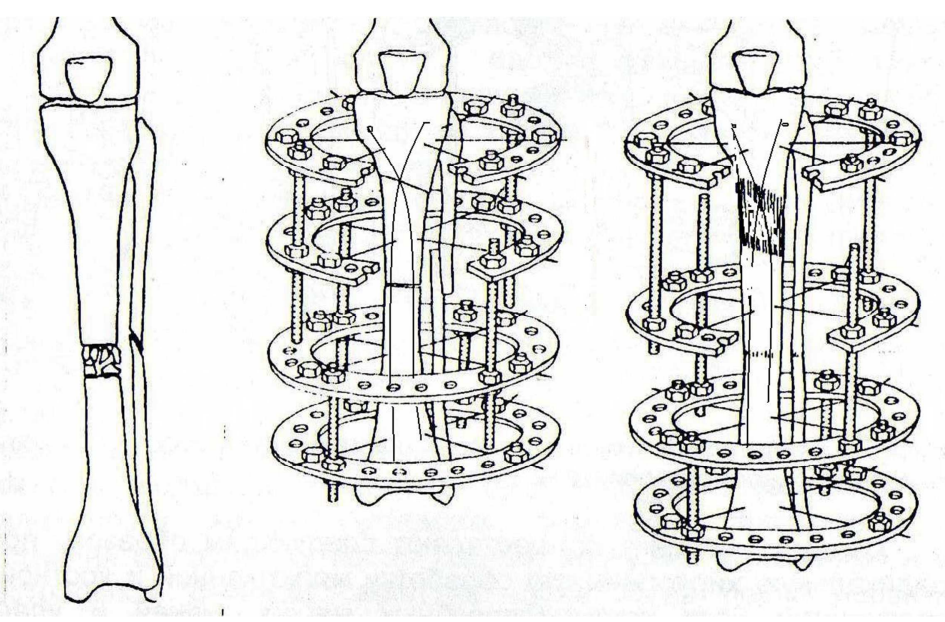

Рис. 5.9. Принципиальная схема билокального комбинированного компрессионно-дистракционного остеосинтеза с интрамедуллярным армированием спицами на примере лечения псевдоартроза голени.

После резекции ложного сустава и остеосинтеза сегмента конечности аппаратом Илизарова осуществляют частичную кортикотомию одного из костных фрагментов. Необходимо подчеркнуть, что наличие расположенных в костномозговом канале спиц требует строгого выполнения методики кортикотомии, поскольку при стандартной остеотомии можно перерубить спицу, и тогда ее удаление из костномозгового канала превратится в сложную хирургическую процедуру.

В послеоперационном периоде, начиная с 8-10-го дня, производят дозированное удлинение укороченного сегмента путем дистракции выделенных костных фрагментов с темпом 0,5-1,0 мм в сутки. В случае сопутствующей деформации одновременно с увеличением продольных размеров сегмента осуществляют устранение ее компонентов. При этом введенные в костномозговой канал эластичные спицы предотвращают вторичные смещения костных фрагментов и, проходя через зону формирования дистракционного регенерата и псевдоартроза, стимулируют репаративный остеогенез.

По достижении необходимой величины удлинения и восстановления биомеханической оси сегмента конечности аппарат переводят в режим стабильной фиксации, которую поддерживают до перестройки участков сформированного регенерата в костную ткань, способную выдерживать статико-динамическую нагрузку.

Сформированный во время периода дистракции костный регенерат благодаря влиянию интрамедуллярных спиц имеет достаточную плотность, чтобы сопротивляться продольному усилию компрессии, предотвращая потерю длины регенерата, или усилию на изгиб. К этому времени наступает консолидация кости и в зоне бывшего ложного сустава. 
Клинический пример. Пациент М., 45 лет. Диагноз: хронический остеомиелит, свищевая форма, псевдоартроз большеберцовой кости и анатомическое укорочение правой голени на 4 см (рис. $5.10 a$, б).

Оперативное лечение открытого перелома (после автодорожной травмы) осложнилось остеомиелитом костей голени. Неоднократные попытки ликвидировать остеомиелит и ложный сустав, предпринятые ранее, закончились неудачно.

Операция: резекция ложного сустава, интрамедуллярное армирование большеберцовой кости спицами с ГА-покрытием и кортикотомия большеберцовой кости в верхней трети голени, билокальный комбинированный компрессионно-дистракционный остеосинтез голени аппаратом Илизарова (рис. рис. 5.10 в).

Удлинение голени началось через 7 дней классическим темпом по 1 мм/день (рис. рис. 5.10z, d). Через месяц дистракции осуществили дополнительное армирование спицами с ГА-покрытием через зону ложного сустава (рис. рис. 5.10 д).

Продолжительность периода фиксации - 3 месяца. После наступления консолидации аппарат был снят (рис. рис. 5.10ж). Дополнительную иммобилизацию осуществляли съемным пластиковым ортезом.

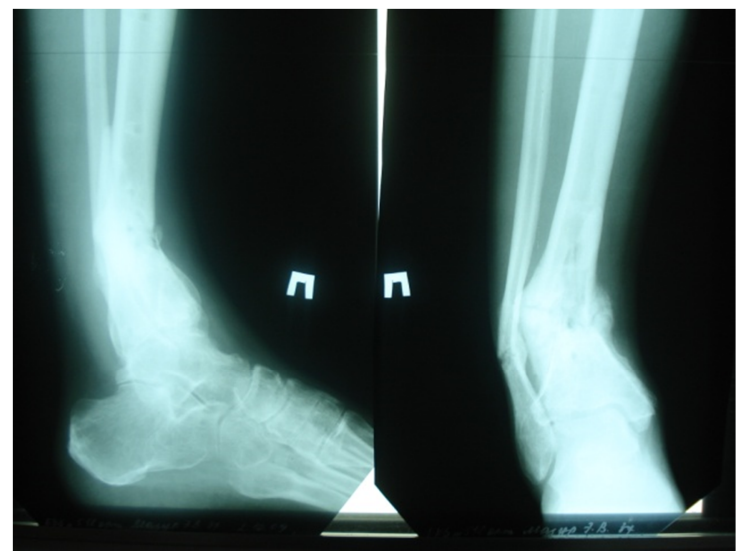

$a$

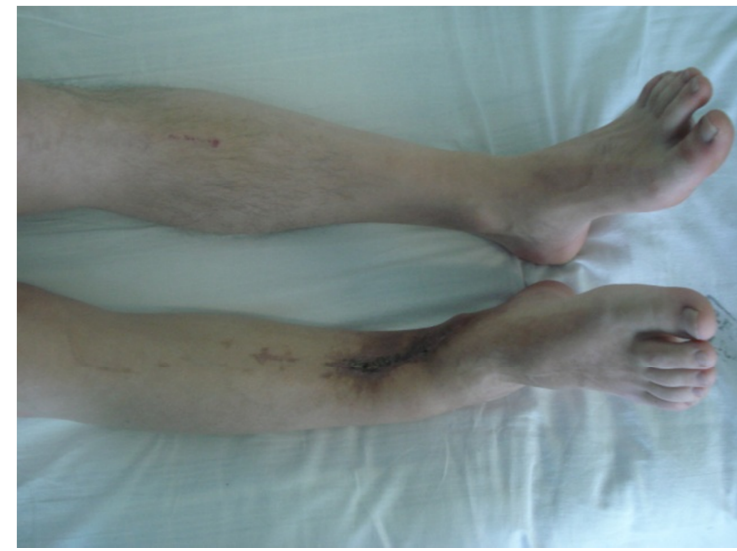

$\sigma$ 


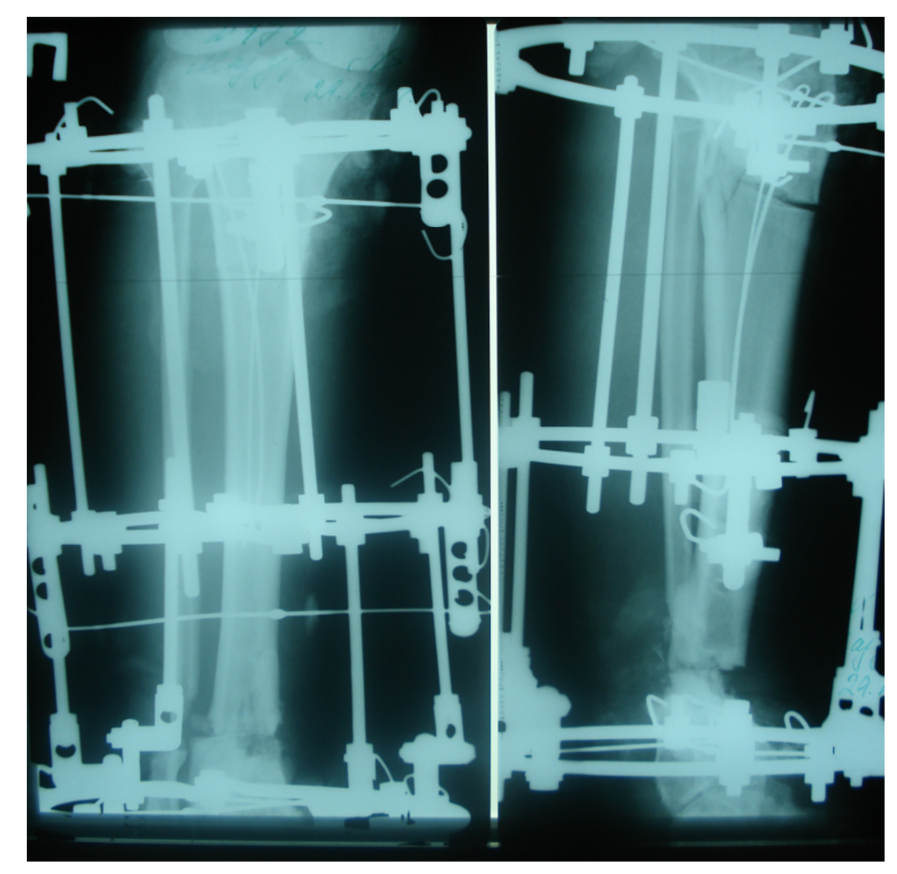

B

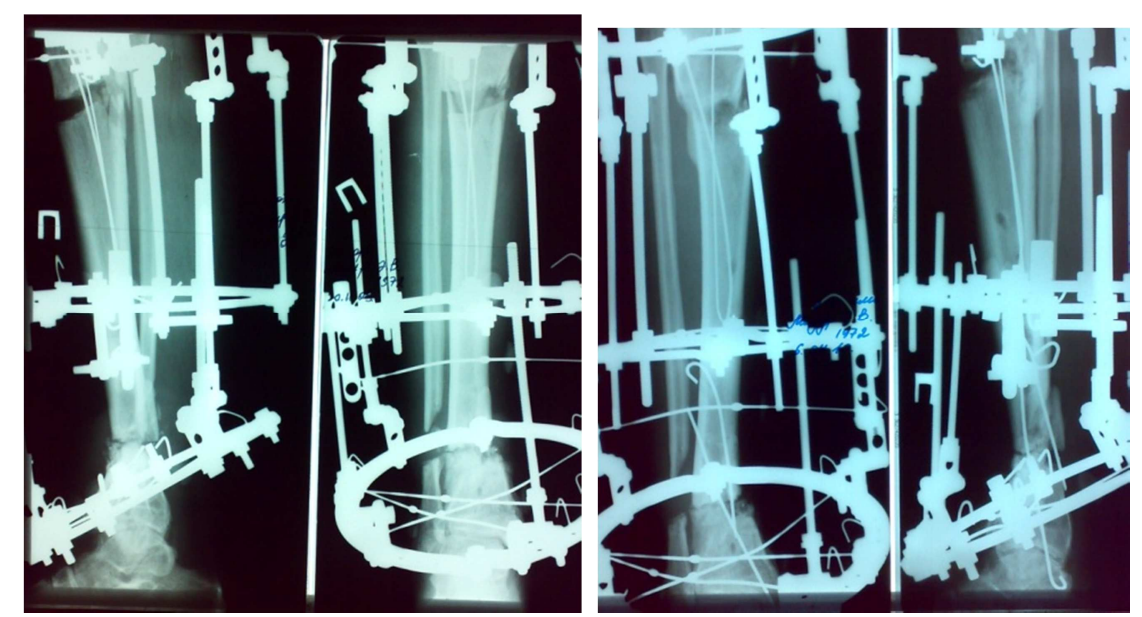

2

$\partial$

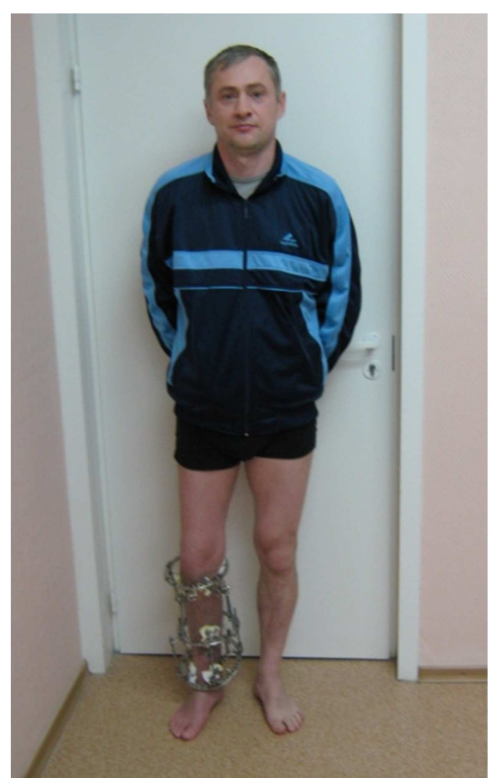

$e$

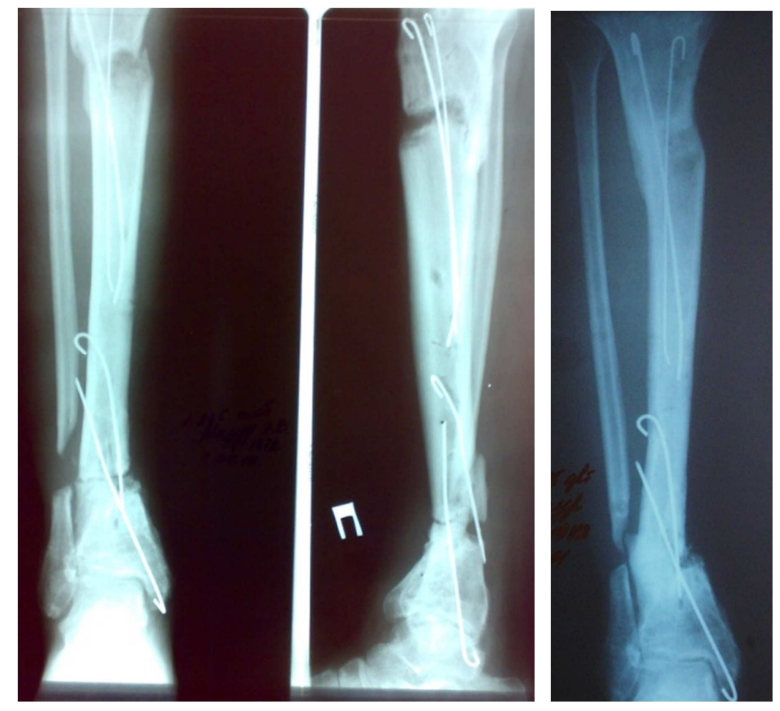


Рис. рис. 5.10. Больной М., 45 лет: $a$ - рентгенограммы костей голени до операции; $\sigma$ - внешний вид голеней до операции; в - рентгенограммы костей голени в день операции; 2 - рентгенограммы костей голени в процессе удлинения; $\partial$ - рентгенограммы костей голени после интрамедуллярного армирования ложного сустава; $e$ - внешний вид в процессе лечения; ж-рентгенограммы костей голени в день демонтажа аппарата; з - рентгенограмма костей голени через 1 год после демонтажа аппарата.

Контрольный осмотр пациента через год после демонтажа аппарата подтвердил консолидацию костных отломков (рис. 5.103), длина ног была одинаковая, свищи не открывались. Пациент - заядлый охотник и рыбак много времени проводит в тайге и на сибирских реках, ходит без дополнительных средств опоры.

Клинический пример. Пациент Х., 47 лет. Диагноз: ложный сустав дистального метаэпифиза лучевой кости, неправильно сросшийся перелом нижней трети локтевой кости левого предплечья, укорочение лучевой кости на 3 см. Комбинированная контрактура локтевого и лучезапястного суставов слева (рис. $5.11 a, \sigma)$.

Операция: резекция ложного сустава лучевой кости, интрамедуллярное армирование лучевой кости, кортикотомия лучевой кости, остеосинтез аппаратом Илизарова (рис. рис. 5.11 в, г).

Остеосинтез продолжался 3 месяца, что явно слишком много, судя по рентгенограмме, сделанной после демонтажа аппарата (рис. рис. 5.11 d). Однако в то время мы только начинали осваивать данный метод лечения и не имели достаточно точных показателей консолидации псевдоартроза (рис. рис. 5.11e).

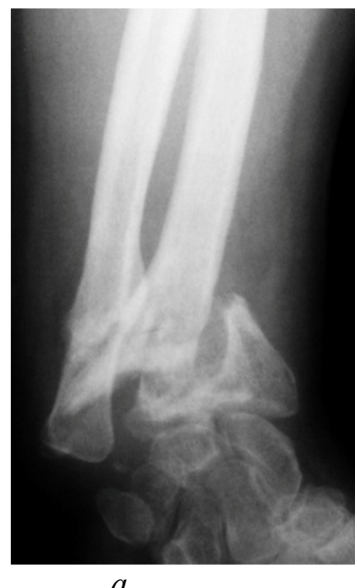

$a$

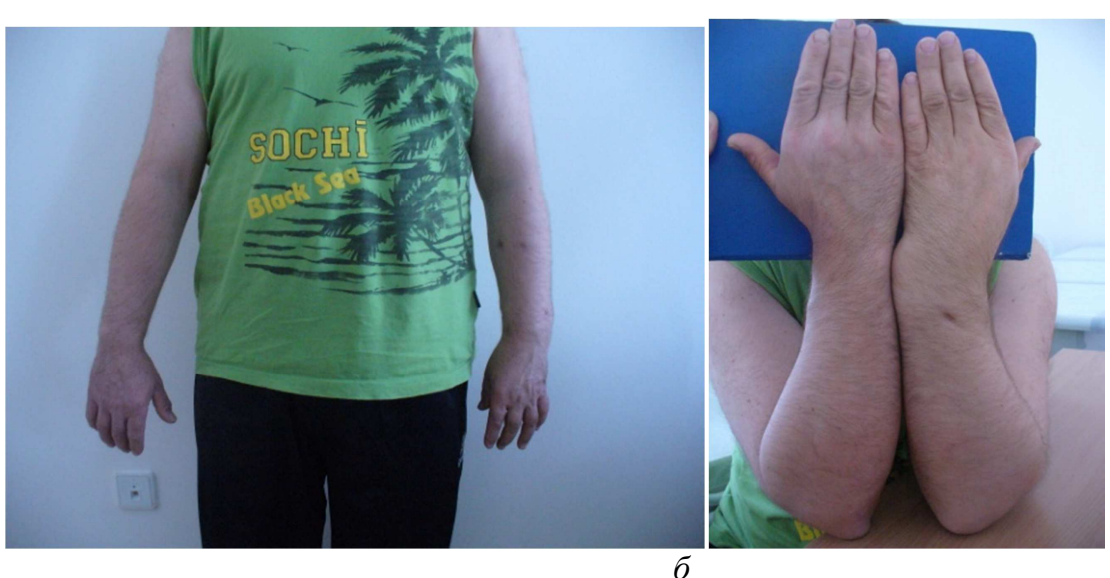

6 


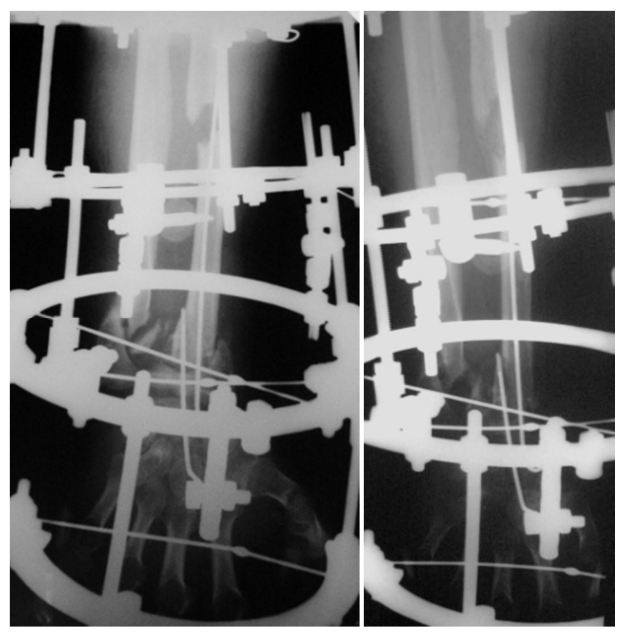

B

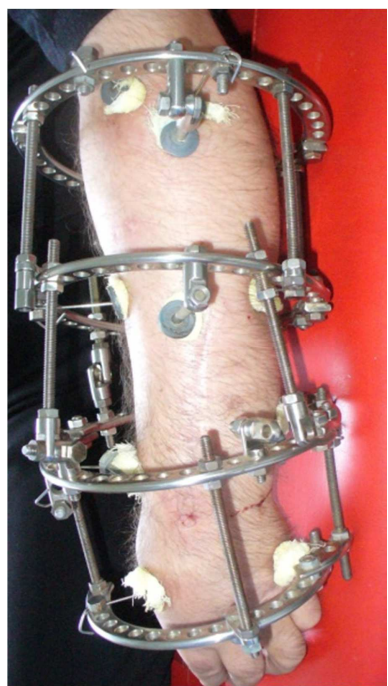

2

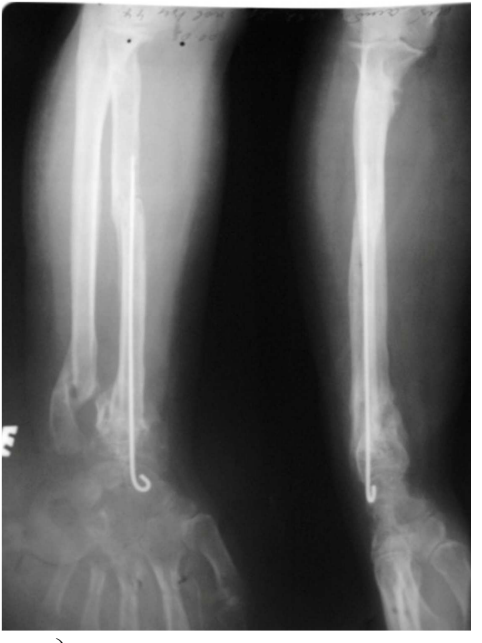

$\partial$

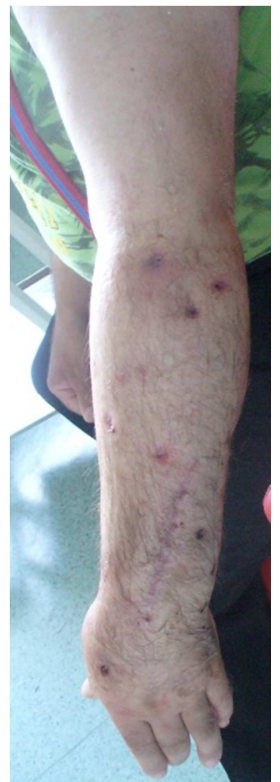

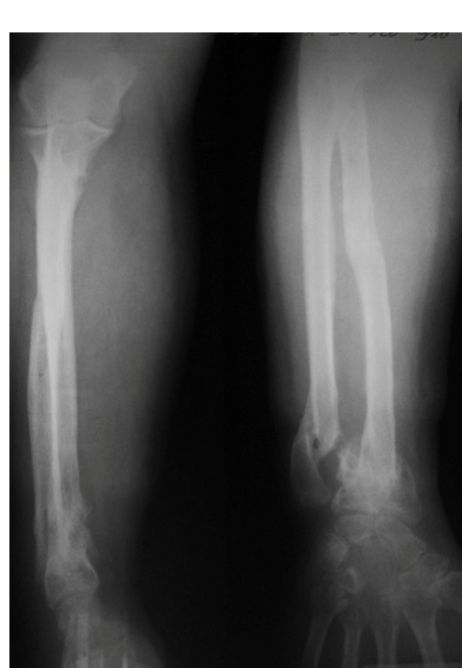

Ж

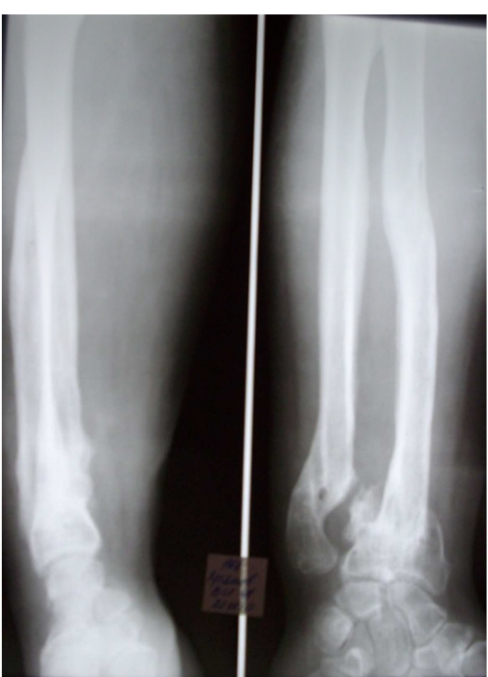

3

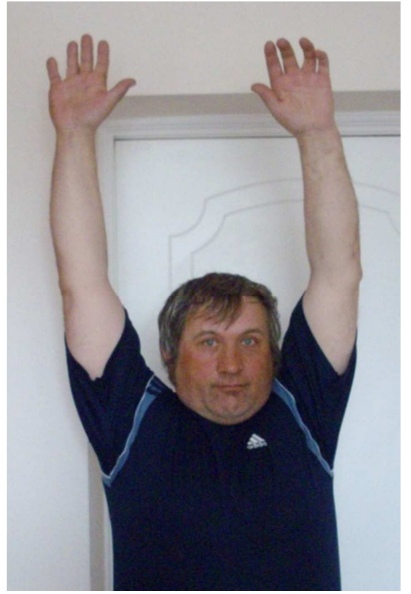

$u$

Рис. 5.11. Пациент Х., 47 лет: $a$ - рентгенограмма костей предплечья до лечения; $\sigma$ - внешний вид больного до лечения; 6 - рентгенограммы костей предплечья в процессе билокального комбинированного компресионно-дистракционного остеосинтеза; 2 - вид руки пациента перед демонтажем аппарата Илизарова; $\partial$ - рентгенограммы костей предплечья после демонтажа аппарата Илизарова; $e$ - вид руки через несколько дней после демонтажа аппарата Илизарова; ж- рентгенограммы костей предплечья через 3 
месяца после демонтажа аппарата Илизарова (интрамедуллярная спица удалена); з - рентгенограммы костей предплечья через 6 месяцев после лечения; $u$ - фото пациента через 6 месяцев после лечения.

Через 3 месяца после демонтажа аппарата Илизарова была удалена интрамедуллярная спица (рис. рис. $5.11 \%$ ).

Нужно заметить, что функциональные возможности пациентов в условиях остеосинтеза по мере консолидации костных фрагментов значительно возрастают, и это наблюдение должно стать для лечащего врача сигналом к решению вопроса о возможности раннего демонтажа аппарата, особенно при лечении патологии верхней конечности.

\section{4. Билокальный последовательный дистракционно-компрессионный остеосинтез}

Методику осуществляют при значительных (более 3 см) дефектах костной ткани, когда одномоментная компрессия в зоне ложного сустава может привести к нарушению кровоснабжения и трофики тканей поврежденной конечности, некрозу окружающих мягких тканей и усугубить общее состояние больного (рис. 5.12). В этом случае последовательное удлинение одного из фрагментов кости до контакта фрагментов, а затем компрессия ложного сустава как нельзя лучше отвечают принципу сберегательного отношения к тканям, обеспечения полноценного кровоснабжения поврежденной конечности.

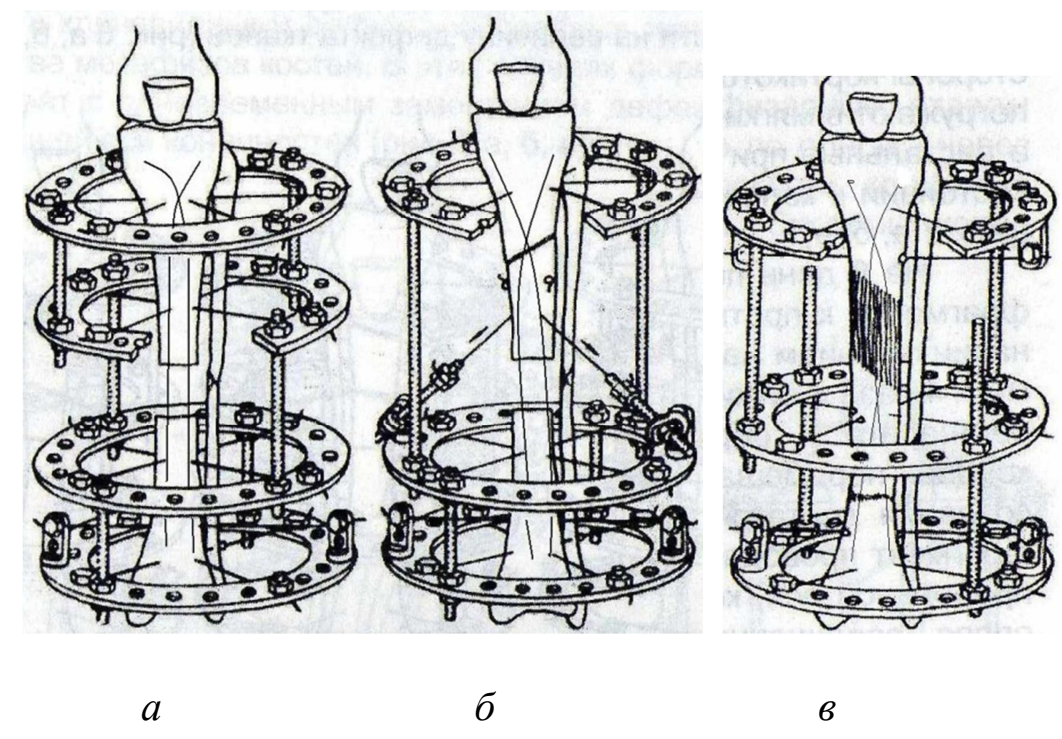

Рис. 5.12. Принципиальная схема билокального последовательного дистракционно-компрессионного остеосинтеза с интрамедуллярным армированием спицами на примере лечения дефекта большеберцовой кости. Объяснение в тексте.

Схема остеосинтеза может быть двух видов в зависимости от величины дефекта кости: 
- при дефекте кости до 5-6 см аппарат Илизарова монтируют из четырех кольцевых опор (рис. 5.12 a), и после кортикотомии проксимального костного фрагмента дистракцию осуществляют между первым и вторым кольцами;

- при дефекте кости более 6 см монтаж аппарата из трех кольцевых опор (рис. 5.12 б) позволяет менее травматично перемещать средний костный фрагмент, а после полного замещения дефекта кости перейти на более стабильный вариант остеосинтеза (рис. 5.12 в).

Клинический пример. Пациент П., 44 года. После травмы (рис. 5.13 а) попытка лечения закрытого перелома локтевой кости в течение 8 месяцев (3 месяца методом накостного и 5 месяцев - чрескостного остеосинтеза) закончилась развитием остеомиелита и резекцией 4 см локтевой кости (рис. 5.13 б).

Методом последовательного дистракционно-компрессионного остеосинтеза дефект кости заместили (рис. 5.13в), однако активность репаративного остеогенеза была незначительной, на основании чего был выставлен диагноз замедленной консолидации в зоне как дистракционного, так и контактного регенерата (рис. 5.13 г). На этом фоне мы осуществили интрамедуллярный остеосинтез спицами с биоактивным ГА-покрытием и иммобилизацию продолжили в ортезе. Через 1 месяц произошла консолидация (рис. 5.13d), функция локтевого сустава сохранилась (рис. 5.13 e), и впервые за последние 16 месяцев появились супинационно-пронационные движения.

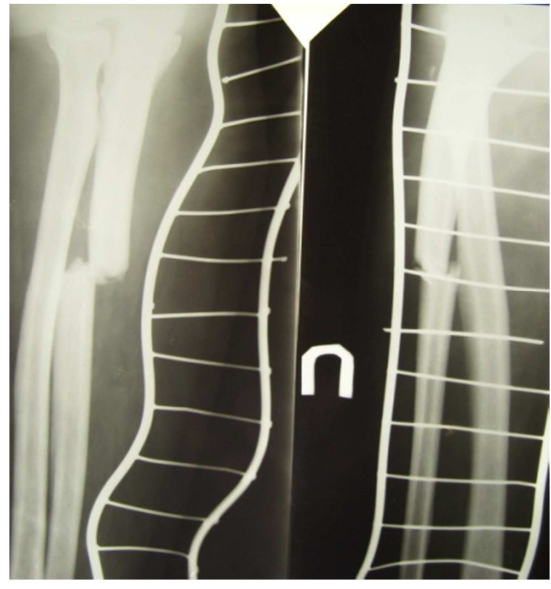

$a$

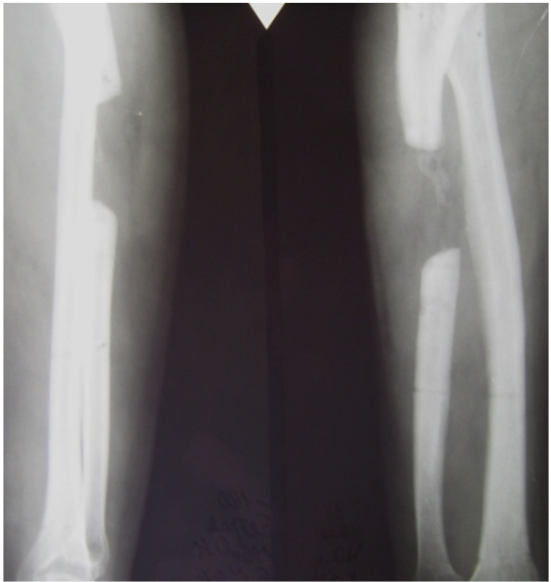

6 


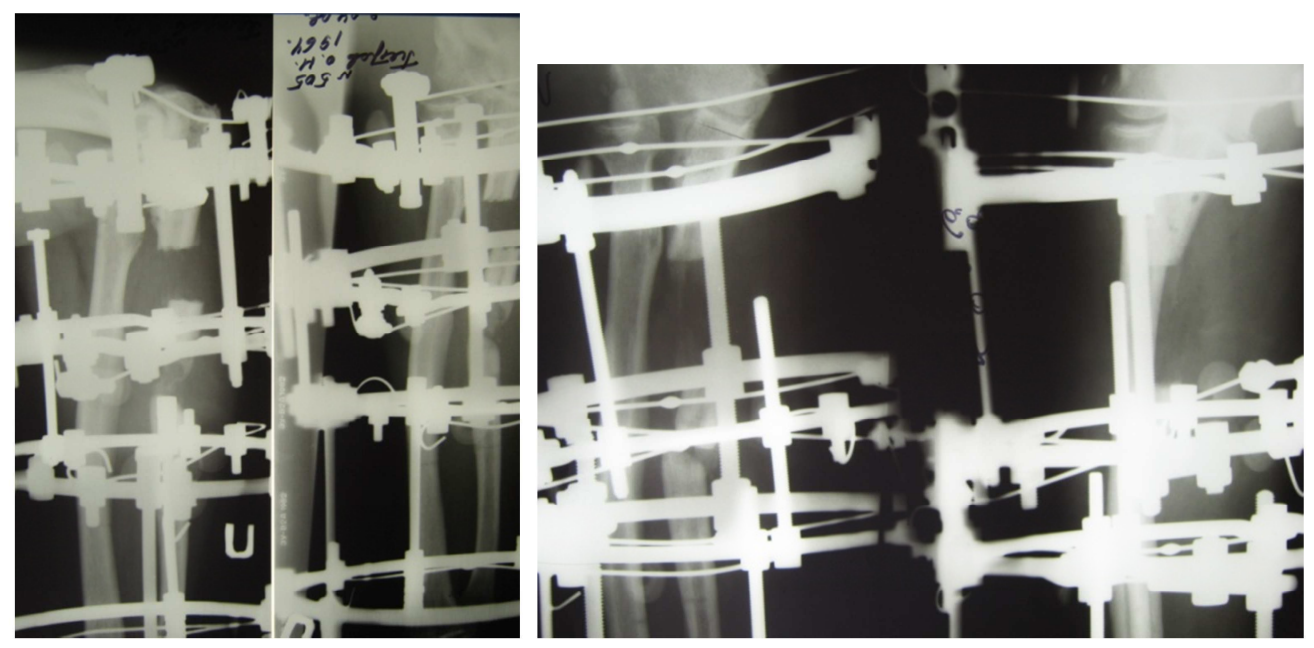

$\boldsymbol{B}$

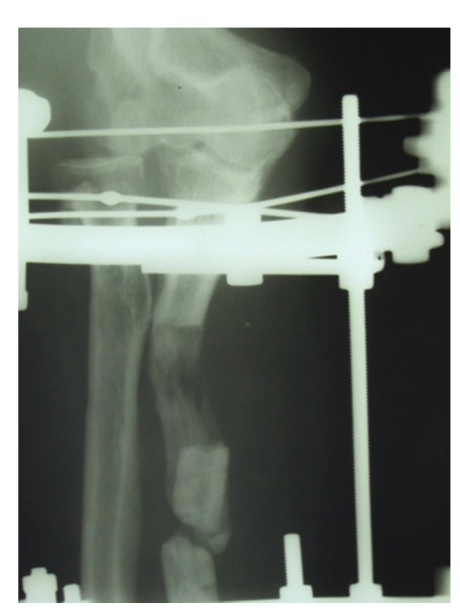

2

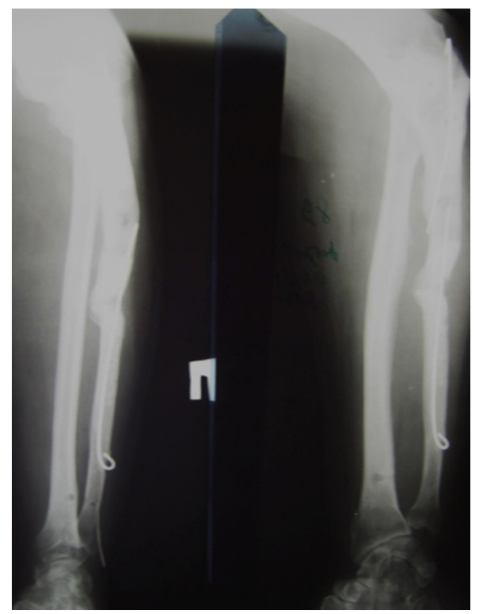

$\partial$

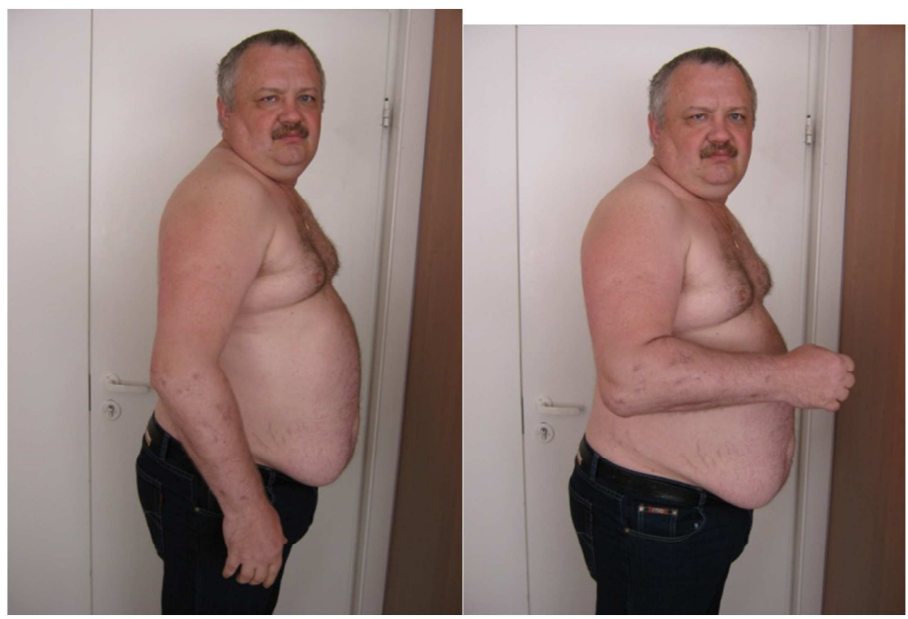

$e$

Рис. 5.13. Пациент П., 44 года: $a$ - рентгенограммы костей предплечья после закрытого перелома локтевой кости; $\sigma$ - рентгенограммы костей предплечья после образования дефекта локтевой кости; 6 рентгенограммы костей предплечья в процессе последовательного дистракционно-компрессионного остеосинтеза (замедленная репаративная регенерация костной ткани); 2 - рентгенограммы костей предплечья через 7 месяцев (перед интрамедуллярным остеосинтезом спицами с ГА-покрытием); $\partial-$ 
рентгенограммы костей предплечья через 1 месяц интрамедуллярного остеосинтеза (произошла консолидация); $e$ - внешний вид и функция конечности.

Методики комбинированного интрамедуллярного остеосинтеза мы с успехом применяли и при одновременном лечении двух сегментов.

Клинический пример. Пациент С., 28 лет. Диагноз: множественные открытые переломы костей обеих голеней и стоп, обширные дефекты мягких тканей (рис. $5.14 a-8$ ).

Повреждения стали последствиями тяжелой автодорожной травмы.

В районной больнице наряду с противошоковыми мероприятиями была проведена ПХО ран с удалением множественных загрязненных осколков правой большеберцовой кости, большого массива размозженных мышц и кожи по передней поверхности правой голени и временная иммобилизация левой голени скелетным вытяжением, а правой голени - аппаратом Илизарова в фиксационном варианте из двух колец.

Нашей задачей при поступлении больного в клинику (через 2 месяца после травмы) было восстановление целостности левой большеберцовой кости и замещение дефекта правой большеберцовой кости в 12 см.

Операция на левой голени осуществлена закрыто по методу компрессионного остеосинтеза аппаратом Илизарова с интрамедуллярным армированием спицами с ГАпокрытием (рис. 5.142-e). Через 1 месяц произошла консолидация, и аппарат Илизарова был демонтирован (рис. 5.14 ж).

Операция на правой голени осложнялась наличием обширного кожно-мышечного лоскута на передней поверхности $(25 \times 27$ см), только что пересаженного микрохирургами, что затрудняло использование ауто- или аллотрансплантации костной ткани для замещения дефекта большеберцовой кости (рис. 5.143). Поэтому мы применили метод последовательного дистракционно-компрессионного остеосинтеза аппаратом Илизарова и интрамедуллярное армирование спицей с биоактивным покрытием (рис. 5.14 $u)$.

Дистракцию дистального фрагмента правой большеберцовой кости начали через 10 дней после операции и продолжали 120 дней (рис. $5.14 \kappa-n)$. Среднесуточный темп составил 1,0 мм/день, что является значительным для дистальной части диафиза большеберцовой кости с пониженными условиями кровоснабжения даже в здоровом организме, а тем более у больного с такой обширной травмой костей и мягких тканей. В зоне контакта костных фрагментов осуществили резекцию костных поверхностей, 
компрессионный остеосинтез и через 2 месяца аппарат Илизарова демонтирован

(наступила консолидация). К этому времени вновь образованный участок большеберцовой кости был способен выдерживать полную нагрузку.

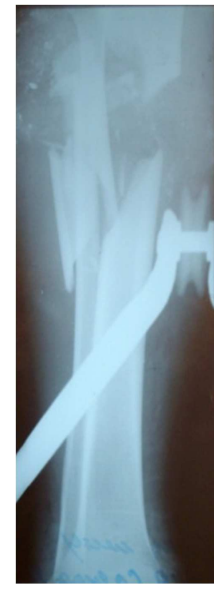

$a$

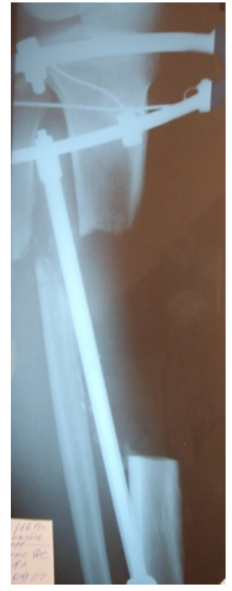

$\sigma$

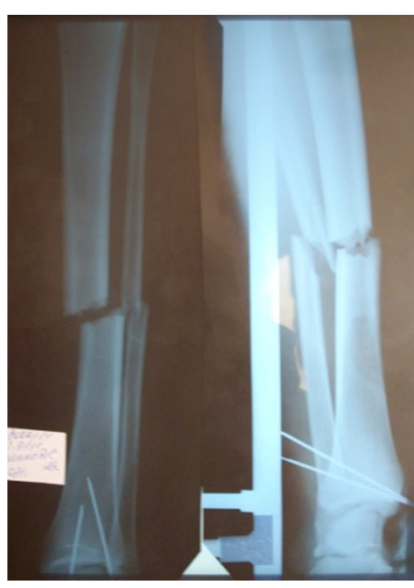

$B$

Рис. 5.14. Пациент С., 28 лет: $a$ - рентгенограмма костей правой голени до ПХО; $\sigma$ - рентгенограмма костей правой голени после ПХО; в - рентгенограммы костей левой голени до остеосинтеза;

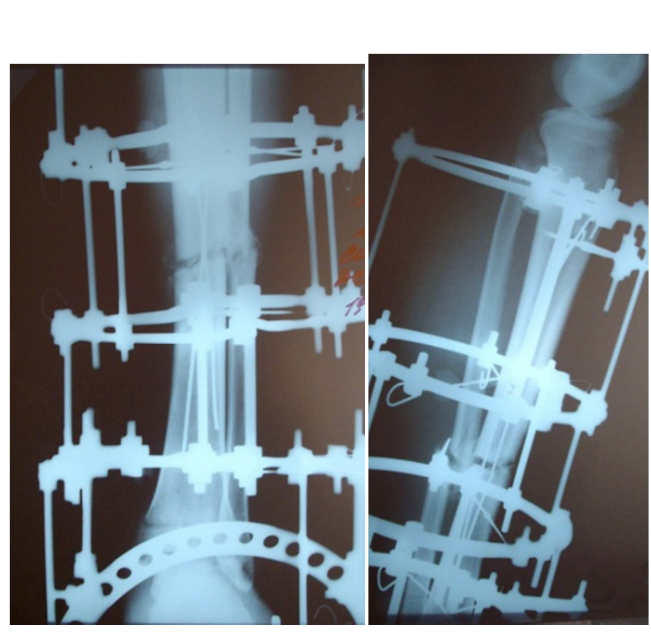

2

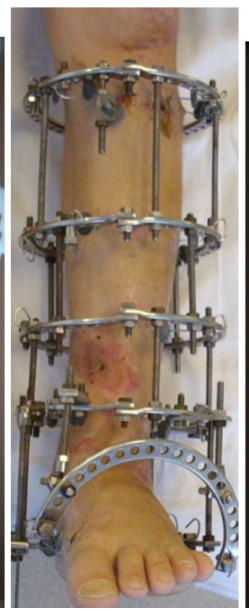

$\partial$

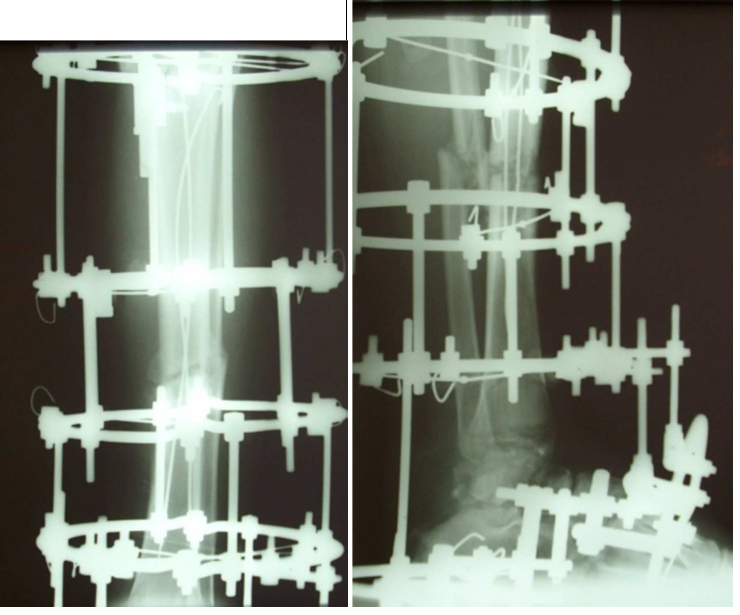

$e$

Рис. 5.14. Пациент С., 28 лет(продолжение): г - рентгенограммы костей левой голени после операции; д вид левой голени после остеосинтеза; е - рентгенограммы костей левой голени через 1 месяц после остеосинтеза;

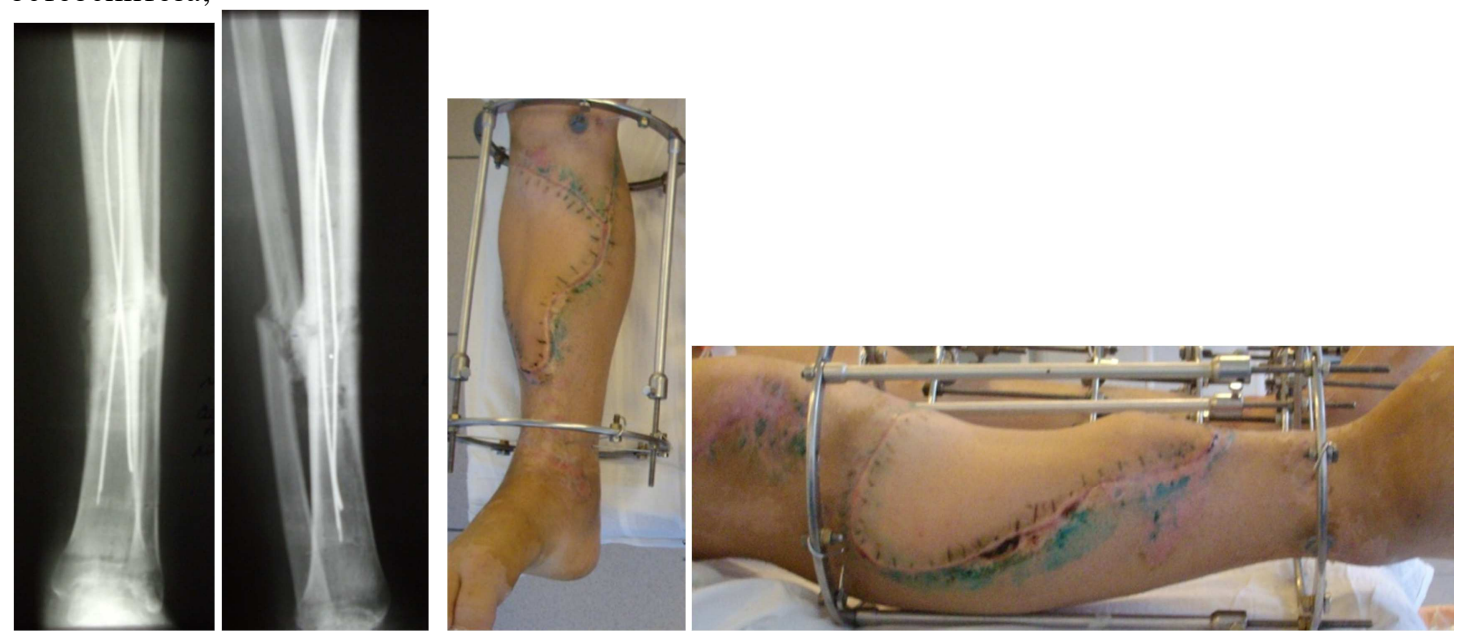




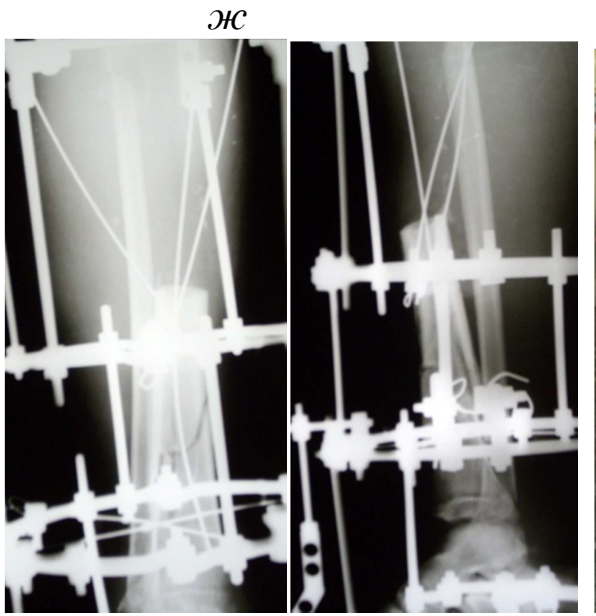

$u$
3

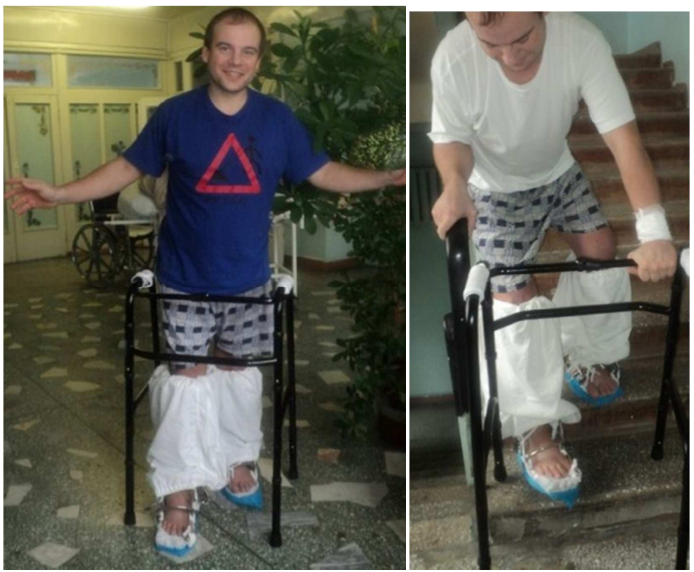

$\kappa$

Рис. 5.14. Пациент С., 28 лет(продолжение): ж - рентгенограммы костей левой голени через 2 месяца после операции; 3 - вид правой голени до операции; и - рентгенограммы правой голени после операции; к внешний вид и функции конечностей через 10 дней после операции;

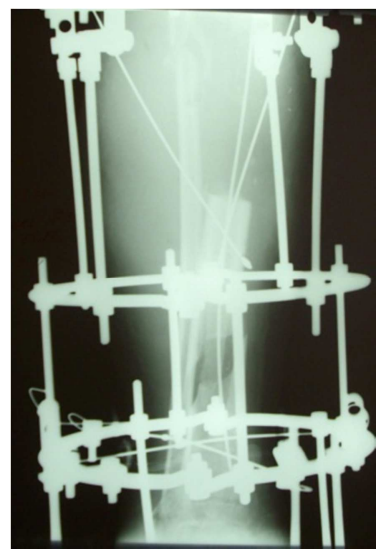

$\pi$

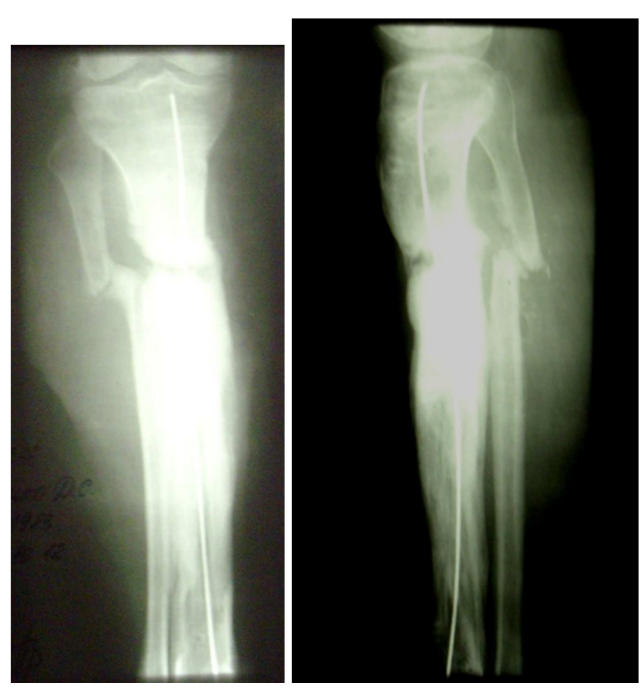

o
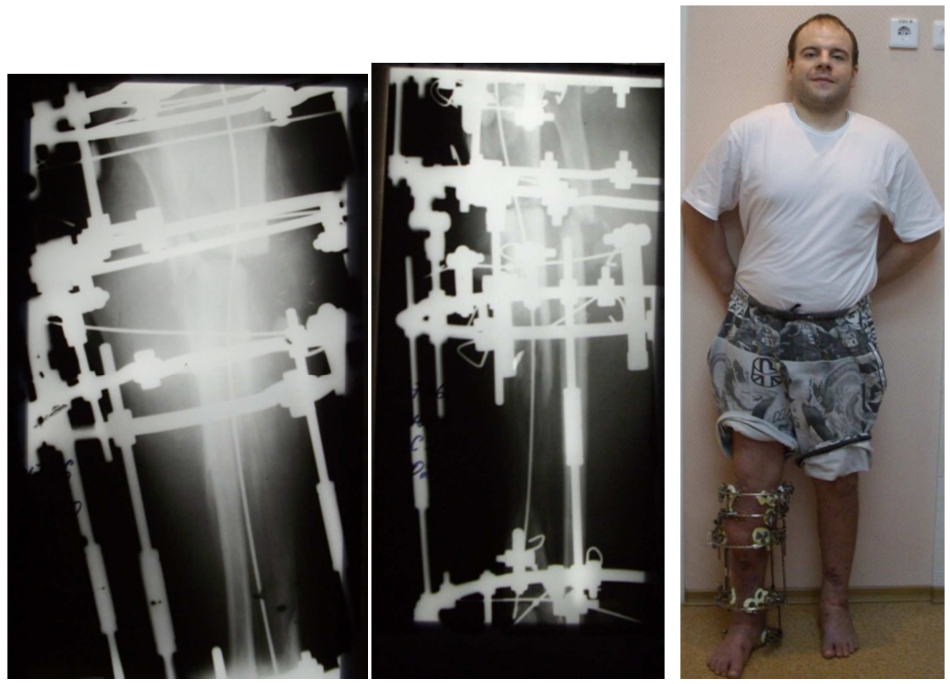

M

H

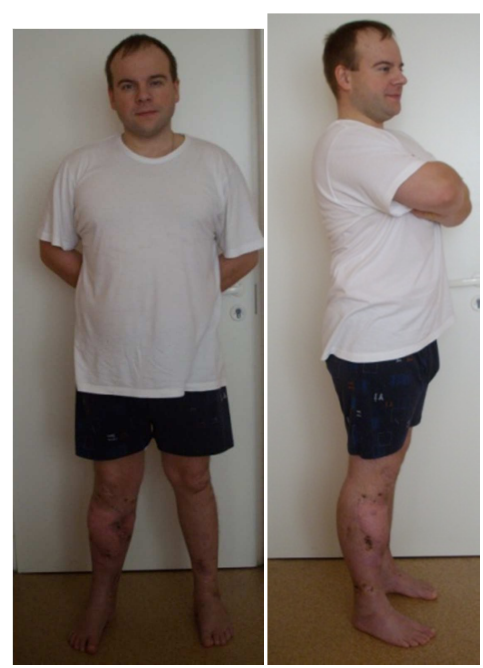

п 


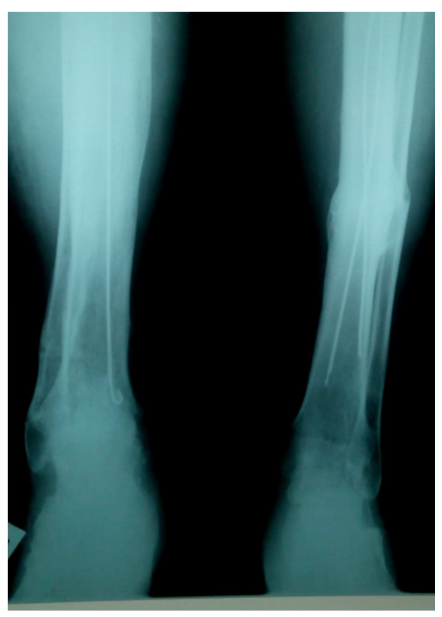

$\mathrm{p}$

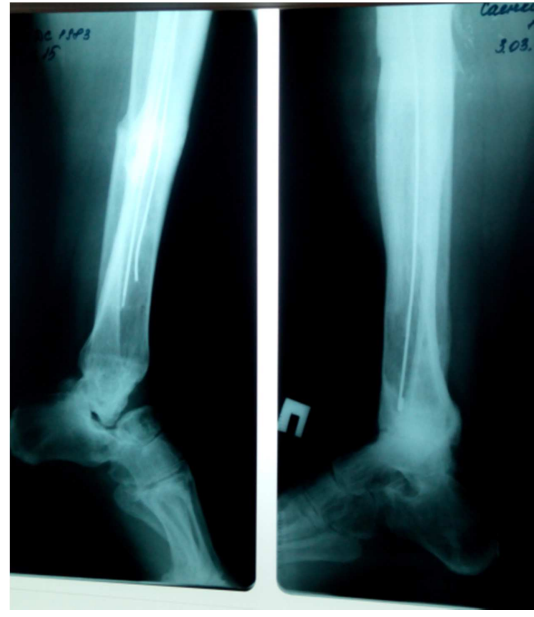

c

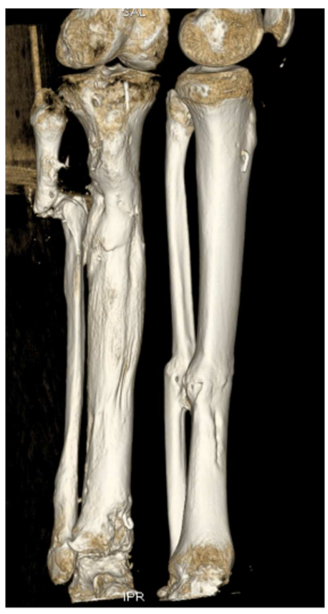

$\mathrm{T}$

Рис. 5.14. Пациент С., 28 лет(продолжение): л - рентгенограмма правой голени через 1 месяц дистракции; м - рентгенограммы правой голени через 120 дней дистракции; н - внешний вид через 120 дней дистракции; о - рентгенограммы правой голени после демонтажа аппарата Илизарова; п- внешний вид пациента после демонтажа аппарата Илизарова; p-c - рентгенограммы обеих большеберцовых косте в двух проекциях через 5 лет после лечения; т - компьютерная томография костей правой голени (3-D реконструкция) через 3 года после лечения.

Отдаленный результат лечения подробно изучен через 3 года. Пациент ходит с полной нагрузкой. Дополнительная опора в виде трости используется им ввиду наличия неоартроза в области подтаранного сустава левой стопы, который после длительной ходьбы отвечает болевым синдромом на нагрузку. Ось конечностей у пациента правильная, отеков нет, амплитуда движений в коленных суставах не ограничена, костный анкилох обоих голеностопных суставов в функционально-выгодном положении.

По данным литературы, результаты лечения дефектов, например, берцовых костей удлинением одного из отломков определяются временем органотипической перестройки дистракционного регенерата. Обычно продолжительности периода фиксации дистракционного регенерата достаточно для перестройки контактного регенерата [Куфтырев Л.М. и др., 1996-2001], и срок фиксации при билокальном комбинированном компрессионно-дистракционном остеосинтезе составлял 180,0 2 25,9 дня, а при билокальном последовательном компрессионно-дистракционном остеосинтезе - 199,0 18,0 дней [Борзунов Д.Ю., 2004].

Анализируя продолжительность периода фиксации у наших пациентов, можно констатировать, что на фоне длительного и травматичного традиционного лечения ложных суставов длинных трубчатых костей, методика интрамедуллярного армирования спицами с биоактивным ГА-покрытием отличается ничтожными экономическими 
затратами при сроках остеосинтеза, не превышающих 3-х месяцев (следует учесть также, что основное время лечения проходит в амбулаторных условиях).

Таким образом, при замедленной консолидации, ложных суставах, дефектах длинных трубчатых костей, в том числе осложненных остеомиелитом, и даже в условиях разрушенного костного мозга интрамедуллярное армирование спицами с ГА-покрытием позволяет стимулировать репаративный остеогенез. 


\section{ЗАКЛЮЧЕНИЕ}

Проблеме восстановления целостности костей после травмы или лечению заболеваний костно-мышечной системы с каждым годом уделяется все более пристальное внимание. И это не удивительно, приняв во внимание тот факт, что рост травматизма и повышение инвалидизации после травм или в связи с заболеваниями костей тесно переплетается со снижением производительных сил нашего общества. Экономические потери от инвалидности колоссальны. По данным специально проведенных исследований прирост числа инвалидов на 150 человек в год эквивалентен затратам в 53015629 рублей, тогда как годовой эффект при своевременной и качественной реабилитации пострадавших от травм в 15,7 раза больше чем затраты на не реабилитированных инвалидов.

Огромны затраты государства и на приобретение различного рода накостных и внутрикостных имплантатов для лечения больных с переломами костей. Например, за 2014 год объемы российского рынка госзаказа по коду ОКПД 33.10.15.612 «Наборы, инструменты, устройства травматологические», и по коду ОКПД 33.10.17.415 «Изделия для соединения костей» составили всего 7580 млн.р. Доля импортной продукции (в основном производства США, Швейцарии, Великобритании, Франции) составляет около 6000 млн. руб., что составляет $80 \%$ рынка госзакупок.

Создание максимально эффективной системы восстановительного лечения больных с травмой и ортопедическими заболеваниями, обеспечивающей сокращение сроков нетрудоспособности, снижение уровня первичной и накопленной инвалидности вот цель достойная внимания современного демократического государства. Пока существующие методы лечения далеко не всегда гарантируют восстановление целостности поврежденного скелета и сроки сращения кости остаются настолько значительными, что законодательство нашей страны вынуждено продлить практически до года период реабилитации прежде чем встает вопрос об инвалидности пострадавшего. В свою очередь, процент полной реабилитации инвалидов заметно снижается [Материалы IX съезда травматологов-ортопедов России, 2009].

Принципиально возможно два направления в решении проблем с повреждениями и заболеваниями костей: механическое замещение дефекта кости имплантатом с созданием сложной биомеханической конструкции или восстановление поврежденной костной ткани через физиологические процессы регенерации.

С нашей точки зрения второе направление является более перспективным и с эстетической точки зрения более приемлемым. Используемые для этой цели имплантаты могут устанавливаться на постоянной основе как армирующая основа для выращиваемой вокруг них кости или как временный имплантат, который удаляется после того как вновь образованное костное вещество заполнило дефект опорного органа и восстановило его функцию.

Основные требования, предъявляемые к имплантатам - устойчивость к коррозионноактивным средам организма и биомеханическая совместимость. Имплантат должен обладать биомеханическими свойствами (прочность, упругость, трещиностойкость) близкими к натуральной кости. Среди материалов, из которых изготавливают имплантаты, выделяют биоинертные и биоактивные с остеокондуктивными и остеоиндуктивными свойствами. 
Остеоиндукция - способность материала вызывать вне кости формирование костной ткани. Чаще всего эта способность проявляется при дополнительном введении остеогенетических факторов (морфогенетический белок, различные факторы роста). Среди остеоиндуктивных материалов наиболее перспективным является керамика на основе гидроксиапатита (ГА), которая биосовместима и наиболее биоактивна. Однако основным ее недостатком является хрупкость. Ликвидировать этот недостаток удалось, покрывая керамикой металлы и сплавы, подвергающиеся механическим нагрузкам.

Существует целый ряд обсуждаемых гипотез механизма остеоиндукции. Например, гипотеза остеоиндукции, утверждающая, что начальный воспалительный отклик после имплантации биоматериала вносит и обеспечивает факторы, которые притягивают мезенхимальные стволовые клетки. Одним из таких факторов может быть простагландин $\mathrm{E}_{2}\left(\mathrm{PGE}_{2}\right)$, который вырабатывается макрофагами, присутствующими вокруг биоматериалов во время воспалительной фазы. Сообщалось, что микрошероховатая поверхность, уникальная для остеоиндуктивных материалов, стимулирует продукцию $\mathrm{PGE}_{2}$ макрофагами.

В литературе достаточно широко обсуждается и концепция управляемого многоуровневого биоинжиниринга, в основу которой положено фундаментальное природное явление - саморегулирование биологических клеток в трехмерные тканевые структуры. Саморегулирование - это фундаментальный процесс, который отвечает за структурную организацию, как в неодушевленных, так и живых системах при котором молекулы (или клетки) спонтанно образуют упорядоченные агрегаты без вмешательства человека. Именно в процессе саморегулирования из отдельных пролиферировавших и дифференцировавших клеток возникает ткань, из которой потом образуется орган. На начальной стадии развитии процесс саморегулирования находится под строгим генетическим контролем, однако, впоследствии саморегулирование в значительной степени идет под управлением физических свойств среды. При этом для того, чтобы клетки развивались и формировали трехмерную структуру тканей и органов, необходимо соответствующим образом структурировать пространство, в котором будет идти развитие. Объекты, выполняющие эту функцию, получили в биоинжиниринге название скаффолдов. Экспериментальное моделирование, показывает, что управляющим параметром развития структуры является механическое напряжение на границе раздела клетка (агрегат клеток) - поверхность скаффолда, которая прямо зависит от топографического паттерна поверхности скаффолда.

Еще в 1973 г. S.F. Hulbert et al. предложили концепцию так называемой биологической фиксации скелетных имплантатов с активным ростом кости на их поверхности. Материалами были оксидные керамические и углеродные соединения, а также металлы, покрытые стабильными оксидными слоями. В нашем случае металлы имеют кальций-фосфатное покрытие. Именно адгезия остеогенных клеток, а также распределение этих клеток будут влиять на их способность пролиферировать и дифференцироваться в остеобласты при контакте с имплантатом. Последнее является определяющим в процессе установки механически прочной границы раздела с интеграцией между поверхностью имплантата и костной тканью без слоя фиброзной ткани, который обычно образуется на поверхности биоинертного металлического имплантата. 
Преимущества таких имплантатов очевидно: в костной ткани ГА присутствует в виде наноразмерных кристаллов, объединяясь в сложные структуры микро- и мезоразмерного масштаба и размещение подобной физической базы в костномозговом канале избавляет клинициста от поиска и введения дополнительных индукторов в виде ферментов, морфогенетических белков, клеточных элементов - весь комплект необходимых веществ в сбалансированном виде уже существует в окружающей спицу высоковаскуляризированной ткани костного мозга.

Развитие подобной технологии имеет множество потенциальных клинических приложений от лечения несрастающихся переломов, ложных суставов, обширных дефектов костной ткани, исправления деформаций различной этиологии, при удлинении конечности и др. Скаффолды с новым уровнем биофункциональности, которые пытаются воссоздать наномасштабные топографические и биофакторные стимулы из внеклеточного окружения, являются крайне интересными биомиметическими материалами.

Проблемы лечения дефектов костной ткани у больных с переломами длинных трубчатых костей, а также больных с ложными суставами, давно требуют поиска новых методов оптимизации процессов остеогенеза. Создание искусственного биоактивного материала в виде интрамедуллярной спицы вооружило хирурга средством, позволяющим вырастить аутокость локально на месте дефекта, значительно улучшить и даже гарантировать результаты лечения больных с переломами и ложными суставами длинных костей конечностей. Одновременно травматичность оперативного вмешательства значительно снизилась, а сроки реабилитации пострадавшего сократились в несколько раз. Нетрудно представить себе будущие легкие и ажурные накостные и внутрикостные имплантаты с оптимальной биоактивной архитектоникой, на поверхности которых активно растет костное вещество используя остеоиндуктивные и остеокондуктивные процессы. Основным способом изготовления подобных имплантатов должна стать аддитивная технология формирования на 3-D принтерах, что превращает травматологию в процесс индивидуального, конкретно для каждого больного, лечения.

Мы полагаем, что некоторые кальций-фосфатные материалы сегодня являются привлекательной альтернативой костным аутотрансплантатам. В экспериментальноморфологических исследованиях доказано, что нанопокрытие ГА обладают выраженным антимикробным свойством и может быть использовано и при лечении инфицированных ран. Нами использовалась технология интрамедуллярного армирования при лечении открытых переломов (после ПХО раны) и при лечении ложных суставов длинных костей осложненных хр. остеомиелитом (после резекции псевдоартроза). Мы не наблюдали случаев обострения остеомиелита или инфицирования тканей вокруг спиц с биоактивным ГА покрытием. Как и при лечении закрытых переломов имплантат проявлял свои остеокондуктивные и остеоиндуктивные свойства матрицы, на поверхности которой в условиях условно асептических и инфицированных костных дефектов формируется новообразованная кость.

Следует отметить, что все наши пациенты проходили амбулаторное лечение не зависимо от того какие способы внешней иммобилизации использовались (аппарат Илизарова или стержневые виды монолатеральных аппаратов). Высокий процент благоприятных исходов сокращение сроков реабилитации и социальной адаптации пациентов, возможность лечения в домашних условиях, несомненно, улучшает качество 
жизни больных со сложной травматологической и ортопедической патологией, и данный метод лечения должен найти широкое применение в практической медицине.

Мы, как сторонники этого нового направления в травматологии-ортопедии, уверены, что организм способен сам восстановить повреждение в очень короткие сроки, если в место дефекта поместить носитель (матрикс) определенных физических и биологических свойств, обеспечивающий оптимальные условия для адгезии, дифференцировки и функционирования остеогенных клеток, недостатка в которых в живом организме нет. Можно даже перечислить некоторые требования к такому носителю:

- этот биоматериал должен соответствовать костной ткани по минеральному составу и дизайну поверхности (многоуровневая характеристика, пористость);

- поверхность биоматериала должна обеспечить высокую способность к адгезии остеогенных клеток;

- биоматериал должен обладать не только остеокондуктивными, но и остеоиндуктивными способностями и обеспечивать возможность непосредственного взаимодействия с биологически активными компонентами костного мозга (морфогенетические белки, стероиды, ферменты, мезенхимальные стволовые клетки и т.д.) или других тканей.

Среди изделий кальций-фосфатной керамики наибольшее внимание ортопедов привлекают нано-гидроскиапатиты и бифазные материалы системы ГА-ТКФ, карбонатсодержащий ГА и октакальцийфосфат (ОКФ). Именно эти соединения обладают контролируемой кинетикой резорбции и отчетливыми остеоиндуктивными и остеокондуктивными свойствами. Вокруг подобных матриксов стабильно фиксированных в дефекте костной ткани активно формируется естественная костная ткань, заполняющая костные полости значительных размеров - предельные возможности объемного распространения костной ткани пока не выяснены.

Необходимо изучить возможность системного влияния ГА керамики на обменные процессы минеральных веществ, что может иметь непосредственное значение для лечения остеопороза и в борьбе с остеопенией.

Еще одним из наиболее актуальных направлений в исследовании индуцирования остеогенеза становиться создание наноструктурированных материалов в системах биополимер-фосфаты кальция. Разработка и внедрение таких материалов станет новым шагом в направлении управления репаративными процессами поврежденных тканей.

Фундаментальные исследования с использованием усовершенствованных методов и современного компьютерного обеспечения в ближайшие годы позволят продвинуть наши знания о кости и ее функциональных способностях по сравнению с нашими нынешними возможностями.

Еще одна область, в которой мы хотели бы продолжить целенаправленные исследования и ожидаем большого продвижения- это соотношения между генотипом и механическими свойствами кости. Изучение этого соотношения едва началось, но уже первые положительные клинические результаты лечения пациентов с генетически обусловленными заболеваниями (несовершенный остеогенез, фосфат-диабет, болезнь Олье и др.) показывают, что вскоре оно станет очень важным. Стимуляция гистогенеза кости показала реальность выхода за пределы генетических алгоритмов остеогенных клеток и их предшественников. Без сомнения, такие исследования потребуют значительных междисциплинарных усилий с участием биологов, генетиков, инженеров, врачей-клиницистов. Уже в настоящее время особое место могут занять хирурги 
травматологи-ортопеды, которые активно и плодотворно работают в НИИТО и Центрах травматологии и ортопедии. Именно они могут определить перспективные направления развития нашей специальности в этот век нанотехнологий и информатики. Для этого помимо медицинских знаний нужны лишь знания физики, химии, математики, биомеханики, биохимии, элементарное знание производства и др. Плодотворное использование творческого потенциала этих специалистов позволит найти новые высокоэффективные методики лечения различных повреждений и заболеваний опорнодвигательной системы человека. 


\section{СПИСОК ОСНОВНОЙ ЛИТЕРАТУРЫ}

1. Алмазов В.А., Ивасенко И.И., Зарицкий А.Ю. Взаимоотношение кроветворного микроокружения, остеогенеза и гемопоэза при взаимодействии эритрона // Бюл. эксперим. биол. и мед. - 1990. - № 2. - С. $140-142$.

2. Авденко, А.Г. Огнестрельные ранения и огнестрельный остеомиелит конечностей. / А.Г. Авденко. - СПб., 2010. - 240 с.

3. Агаронян Р. Г. Комплексный подход к тактике лечения переломов шейки бедренной кости // Мед. вестник Эребуни. - 2010. - № 3 (43). - С. 15-19.

4. Агаджанян, В.В. Политравма / В.В. Агаджанян [и др.] - Новосибирск : Наука, 2003. 492 c.

5. Агаджанян В.В., Пак В.П. Профилактика гнойных осложнений открытых переломов голени на раннем госпитальном этапе // Ортопедия и травматология. - 1984. - № 10. C. $14-17$.

6. Агаджанян В.В. Остеоиндуктивные покрытия на основе фосфатов кальция и перспективы их применения при лечении политравм / В.В.Агаджанян, С.И.Твердохлебов, Е.Н.Больбасов, В.П.Игнатов, Е.В. Шестериков // Политравма. 2011. - №. 3. - С. 5-13.

7. Азизов М.Ж., Салиев М.М. Состояние и перспективы развития травматологоортопедической науки в Узбекистане // Новые технологии в травматологии и ортопедии: материалы VI съезда травматологов-ортопедов Узбекистана. - Ташкент, 2003. - С. 5-9.

8. Акулич Ю. В. Влияние количества и размеров резьбовых фиксаторов на адаптационные изменения механических свойств губчатой костной ткани и усилие сжатия отломков после контролируемого остеосинтеза перелома шейки бедра / Ю. В. Акулич, А. Ю. Акулич, А. С. Денисов // Рос. журн. биомеханики. - 2012. - Т. 16 № 2 (56). - С. 21-29.

9. Анкин Н. Л. Остеосинтез и эндопротезирование при переломах шейки бедра // Вестн. травматологии и ортопедии им. Н.Н. Приорова. - 1997. - № 2. - С. 19-22.

10. Анкин Л.Н., Анкин Н.Л. Травматология (Европейские стандарты). - М.: МЕДпресс-информ, 2005. - 495 c.

11. Аронов А.М. Методические основы разработки и организации производства медецинских изделий / А.М. Аронов, В.Ф.Пичугин, С.И.Твердохлебов. - Томск: Ветер, 2007. - $334 \mathrm{c}$.

12. Аронов А.M Биокомпозиты на основе сополимера тетрафторэтилена с винилиденфторидом, наполненного гидроксиапатитом, и возможность их применения в качестве покрытия для интрамедуллярных имплантатов / Аронов А.M., Больбасов Е.Н., Гузеев В.В. и др. // Мед. технол. - 2010. - № 3. - С. 5-13.

13. Ахмедов, Б.А. Комплексное лечение раненых с высокоэнергетическими огнестрельными переломами длинных костей конечностей / Б.А. Ахмедов [и др.] // Сборник тезисов IX съезда травматологов-ортопедов России. - Саратов, 2010. - Т. 1. C. $82-83$.

14. Ахметьянов Р.Ф. Особенности первичной инвалидности вследствие травм и других внешних воздействий в РФ // Мед.-соц. эксп. и реабил. - 2005. - № 1. - С. 37-40.

15. Барабаш А.П., Соломин Л.Н. Комбинированный напряженный остеосинтез. Благовещенск, 1992. - 70 с.

16. Барабаш А.П. Аспекты методологии и практической реализации в технологии лечения больных с последствиями травм конечностей // Травматология и ортопедия России. - 1995. - № 4. - С. 14-17.

17. Барабаш А.П., Барабаш И.В., Барабаш Ю.А. Вегетативный гомеостаз и центральная гемодинамика при хирургической агрессии. - Иркутск, 1999. - 94 с.

18. А. В. Басов Лечение переломов шейки бедренной кости канюлированными винтами / 
А. В. Басов и др. // Политравма. 2012. № 1. С. 32-37.

19. Бекчанов С.3., Валиев Э.Ю., Сайфуллаев О.Э., Миржалилов Ф.Ж. Ошибки и осложнения в лечении оскольчатых и полифокальных переломов костей голени // Журн. теорет. и клин. мед. - 2009. - № 1. - С. 53-56.

20. Беляевский, А. Д. Концентрация миоглобина в плазме крови как один из критериев оценки тяжести травматической агрессии при сочетанной черепно-мозговой травме / А. Д. Беляевский, И. В. Русская, С. А. Беляевский // Вестник интенсивной терапии. 1999.-№1.-С. 68-69.

21. Берхин, Е. Б. Методы экспериментального исследования почек и водно-солевого обмена. / Е. Б. Берхин, Ю. В. Иванов. - Барнаул : Алтайск. кн. изд-во, 1972. - 120 с. ;

22. Бецишор, В. К. Особенности течения и лечения множественных переломов костей конечностей и их последствий: автореф. дис... д-ра мед. наук / В. К. Бецишор. - М., 1988. - 33 c.

23. Биохимические детерминанты и механизмы развития экстремальной гипоксической гипоксии/ В. В. Горанчук, Е. Б. Шустов, Л. И. Андреева и др. // Физ. человека. - 1999. № 4. - С. 118-129.

24. Биохимические методы оценки тяжести эндогенной интоксикации у больных с термическими ожогами: инструктивно-методическое письмо. / Р. И. Лифшиц, И. А. Волчегорский, В. Е. Рябинин, А. К. Однопазов, А. Ю. Холодов, А. С. Пружевский. Челябинск, 1988. - 16 с.

25. Биохимические показатели при экстремальной воздушной гипотермии/ B. B. Горанчук, Е. Б. Шустов, Л. И. Андреева и др. // Физ. человека. - 1999. - № 6. - С. 96 104.

26. Богов А.А., Плаксейчук А.Ю. Чрескостный остеосинтез и микрохирургическая трансплантация при лечении дефектов костей предплечья // Вопросы травматологииортопедии и восстановительной хирургии: науч. тр. - Казань, 1993. - С. 73-76.

27. Борзунов Д.Ю. Замещение дефектов длинных костей полилокальным удлинением отломков: автореф. дис. ... д-ра мед. наук. - Курган, 2004. - 43 с.

28. Быков А. Т.,. Питерская Я. А, Труханов А. И. Коррекция кардиореспираторного сопряжения технологий биоуправления при психофизиологической дезадаптации / Вестник восстановительной медицины. - 2007. - №2. - с. 34 - 42.

29. Быков В.М. Лечение переломов длинных трубчатых костей у детей методом закрытого чрескожного остеосинтеза / В.М. Быков, М.Ф.Ковшова, О.В.Горшенина // Актуальные вопросы детской травматологии и ортопедии : Сб.,науч. тр. - М., 2001. C.327-328.

30. Бялик Е.И., Соколов В.А., Семенова Н.М. и др. Особенности лечения открытых переломов длинных костей у пострадавших с политравмой // Вестн. травматол. и ортопед. им. Н.Н. Приорова. - 2002. - № 4. - С. 3-8.

31. Губко А.А. Осложнения при открытых переломах длинных трубчатых костей и их профилактика: метод. рекомендации. - Минск, 1980.

32. В. А. Копысова Костно-пластическая реконструкция проксимального отдела бедренной кости у пациентов с переломами и ложными суставами шейки бедра / В. А. Копысова [и др.] // Вестн. травматологии и ортопедии им. Н. Н. Приорова. - 2009. - № 4. - С. 23-28.

33. Викторова Н.Л. Экспертная оценка лечения диафизарных переломов длинных трубчатых костей // Анналы травматологии и ортопедии. - 1995. - № 1. - С. 8-10.

34. Власов, В. В. Реакция организма на внешние воздействия: общие закономерности развития и методические проблемы исследования / В. В. Власов. - Иркутск : Из-во Иркут. ун-та, 1994. - 344 с.

35. Войтович Р.Ф.Высокотемпературное окисление титана и его сплавов / Р.Ф. Войтович, Э.И.Головко. - Киев: Наук. думка, 1984. - 256 с. 
36. Г.А. Шевалаев Переломы проксимального отдела бедра у взрослых / Г.А. Шевалаев, В.П. Демин, Б.К. Волгаев, И.М. Ефремов / Альманах современной науки и образования, № 5 (24) 2009 г.- С.181-182.

37. Гаркави, Л. Х. Антистрессорные реакции и активационная терапия. Реакции активации как путь к здоровью через процессы самоорганизации / Л. Х. Гаркави, Е. Б. Квакина, Т. С. Кузьменко. - М. : Имедис, 1998. - 654 с.

38. Герасимов Ю.В., Фриденштейн А.Я., Чайлахян Р.К. и др. Дифференцировочные потенции клональных штаммов костномозговых фибробластов // Бюл. эксперим. биол. и мед. - 1986. - № 6. - С. 717-719.

39. Гераськина, М. А. Изменение уровня перекисного окисления липидов крови при длительной гиподинамии / М. А. Гераськина // Вест. Морд. Ун-та., 1996. - № 3. - С. 59 $-61$.

40. Героева Е. В. Новые подходы к выбору хирургической тактики лечения пожилых больных с переломом шейки бедренной кости // Новые мед. технологии. Новое мед. оборудование. - 2011. - № 8. - С. 28-32.

41. Гладкова Е.Н. Теоретические основы и технология паротермического оксидирования. - Саратов: Изд-во Сарат. ун-та, 1973. - 99 с.

42. Голубев В.Г., Гришин И.Г., Костова В.К. Васкуляризационные костные трансплантаты при лечении врожденных ложных суставов // Проблемы микрохирургии: тез. III Всесоюз. симпозиума по микрохирургии. - Саратов, 1989. - С. 201-202.

43. Голяховский В., Френкель В. Руководство по чрескостному остеосинтезу методом Илизарова. - М.: БИНОМ, 1999. - 272 с.

44. Горанчук, В. В. Биохимические показатели при развитии экстремальной гипертермии / В. В. Горанчук, Е. Б. Шустов // Физ. человека, 1997. - № 4. - С. 98 - 105.

45. Горев С. Г. Показатели липидного обмена в сыворотке крови в зависимости от репаративных процессов при травме/ С. Г. Горев, Е. П. Еликова, О. А. Тукмачев и др. // Вест. новых мед. технологий. - 2002.- № 2.- С. 31 - 32.

46. Горизонтов П.Д., Белоусова О.И., Федотова М.И. Стресс и система крови. - М.: Медицина, 1983. - 239 с.

47. Городниченко, А.И. Чрескостный остеосинтез около- и внутрисуставных переломов длинных костей конечностей / А.И. Городниченко, А.Н. Минаев, О.Н. Усков // Сборник тезисов IX съезда травматологов-ортопедов России. - Саратов, 2010. - T. 1. C. 114.

48. Гражданов К.А. Чрескостный остеосинтез в лечении свежих и несросшихся переломов плечевой кости / К.А. Гражданов, В.Д. Балаян, О.Л. Ананьев //IX съезд травматологовортопедов России : Тез. докл. - Саратов, 2010. - Т. 1. - С. 116-117.

49. Гришина Л.П. Основные тенденции формирования первичной инвалидности взрослого населения в России за 10 лет (1994-2003) // Мед.-соц. эксп. и реабил. - 2005. - № 3. C. 15-17.

50. Гришин И.Г., Голубев В.Г., Крошкин В.Г., Богдашевский Д.Р. Пластика обширных дефектов длинных костей васкуляризованными малоберцовыми трансплантатами // Вестн. травматол. и ортопед. им. Н.Н. Приорова. - 2001. - № 2. - С. 61-65.

51. Гуманенко, Е. К. Объективная оценка тяжести травмы / Е. К. Гуманенко, В. В. Бояринцев, Т. Ю. Супрун. - СПб., 1999. - 109 с.

52. Двойнин, Л. А. Травматический токсикоз от самосдавления / Л. А. Двойнин // Клиническая хирургия. - 1971. - № 8. - С. 78 - 80.

53. Девятов, А.А. Чрескостный остеосинтез. - Кишинев : Штиинца, 1990. - 315 с.

54. Дедушкин В.С. Огнестрельные ранения кисти. - М.: Медицина, 1999. - 231 с.

55. Десятниченко К.С. О нейро-гуморальных механизмах контроля за репаративным остеогенезом // Лечение ортопедо-травматологических больных методами чрескостного остеосинтеза в стационаре и поликлинике, разработанными в КНИИЭКОТ: тез. докл. Всесоюз. науч.-практ. конф. - Курган, 1982. - С. 152-154. 
56. Дубикайтис, А. Ю. Острые и хронические эндотоксикозы у хирургических больных: автореф. дис... д-ра мед. наук / А. Ю. Дубикайтис. - Санкт-Петербург, 1993. - 60 с.

57. Дубров Я. Г. Пособие по травматологии/ Я. Г. Дубров. - М.: Медицина, 1965. - 259 с

58. Дубров Я. Г. Лечение закрытых переломов бедра методом внутрикостной фиксации. Хирургия, №10, 1947.

59. Ежов И. Ю. Результаты лечения больных с переломами шейки бедренной кости и их последствиями : материалы 13 Рос. нац. конгресса "Человек и его здоровье" / И. Ю. Ежов [и др.] // Травматология и ортопедия России. - 2008. - Приложение к № 4 (50). C. 44-44.

60. Еликов, А. В. Показатели метаболизма липидов и гемодинамики у лиц с различным уровнем адаптационного потенциала / А. В. Еликов, П. И. Цапюк // Актуальные проблемы теоретической и прикладной биохимии : мат. конф. биохимиков Урала, Поволжья и Западной Сибири. - Ижевск, 2001. - С. 31 - 33.

61. Ершова О.Б. Результаты проспектив-ного изучения исходов переломов проксимального отдела бедра у лиц пожилого возраста / О.Б. Ершова, О.В.Семенова, А.А. Дегтярев // Остеопороз и остеопатии. - 2000. - №1. - С. 9-10.

62. Есаян, А. М. Влияние мочевины на течение экспериментальной уремии у крыс с субтотальной нефректомией / А. М. Есаян, В. А. Титова, Л. И. Шишкина // Патол. физиол. - 1997. - № 2. - С. 39 - 41.

63. Жанаспаев A.M. Специализированная травматологическая помощь городскому населению и совершенствование методов лечения диафизарных переломов костей нижней конечности: автореф. дис. ... д-ра мед. наук. - М., 1992. - 48 с.

64. Жук Н.П. Курс коррозии и защиты металлов. - М.: Изд-во «Металлургия», 1968. $408 \mathrm{c}$.

65. Журавлев C.M. Травматизм и ортопедическая заболеваемость - приоритетная медицинская и демографическая проблема: актовая речь на расширенном заседании Ученого Совета 19 декабря 1997 г. - М.: ЦИТО, 1997. - 46 с.

66. Зайчик, А. Ш. Основы общей патологии. Часть 1. Основы общей патофизиологии / А. Ш. Зайчик, Л. П. Чурилов - СПб.: Элби, 1999. - 624 с.

67. Зайчик, А. Ш. Патофизиология Том 2. Основы патохимии / А. Ш. Зайчик, Л. П. Чурилов. - СПб.: Элби, 2001. - 687 с.

68. Зарицкий А.Ю., Каждан И.Я., Кулик М.А. Колониеобразующая способность фибробластных клетокпредшественников костного мозга у больных хроническим лейкозом // Тер. архив. - 1982. - № 8. - С. 12-123.

69. Зарицкий А.Ю., Глибин В.Н., Кулик М.А. и др. Колониеобразующая способность фибробластных клеток-предшественников у человека при переломах костей // Гематол. и трансфузиол. - 1983. - № 5. C. $45-47$.

70. Земченков, А. Ю. «К/ДОКИ» обращается к истокам хронической почечной недостаточности / А. Ю. Земченков, Н. А. Томилина // Тефрология и диализ. - 2004. T. 6. - № 3. - C. $204-220$.

71. Зоря В.И.Оперативное лечение ложных суставов шейки бедренной кости / В.И.Зоря, Паршиков М.В. // Вестник травматологии и ортопедии им. Н.Н. Приорова. - 1996. №2. - С. 25-27.

72. Зубкова, С. М. Участие антиоксидантных систем в адаптивных реакциях организма на действие физических факторов / С. М. Зубкова // Вопр. кур., физиотер. и леч. физкультуры. - 1997. - № 2. - С. 3-7.

73. Зуфаров, К. А., Структурно-функциональная характеристика почек в постиатальном онтогенезе / К. А. Зуфаров, В. М. Гонтмахер // Онтогенез почки : сб. научн. трудов. Новосибирск. - 1984. - С. 14-24.

74. Иванников С. Наружный чрескостный остеосинтез при переломах костей предплечья / Медицина, 2003.- 103 с. 
75. Ивашкевич С.Г. Клинико-лабораторное обоснование применения дентальных имплантатов с покрытием электретного типа : автореф. дис... канд. мед.наук, 2007. С. 5 .

76. Изабеков Ч. Н. Лечение переломов шейки бедра на фоне остеопороза // Актуальные вопросы травматологии и ортопедии на современном этапе: материалы международ. науч.-практ. конф. (1-2 ноября 2007 г., г. Алматы) / Ч. Н. Изабеков, В. В. Красоцкий // Травматол. жэне ортопед.. - 2007. - Т. 2, № 2 (Спец. выпуск). - С. 102-104.

77. Илизаров, Г.А. Клинические возможности нашего метода // Экспериментальные, теоретические и клинические аспекты, разрабатываемого в КНИИЭКОТ метода чрескостного остеосинтеза. -Курган. - 1983. - С. 16.

78. Илизаров Г.А. Некоторые теоретические и клинические аспекты чрескостного остеосинтеза с позицией открытых нами общебиологических закономерностей // Экспериментальнотеоретические и клинические аспекты разрабатываемого в КНИИЭКОТ метода чрескостного остеосинтеза: тез. докл. Всесоюз. симпозиума. - Курган, 1986. - С. 7-12.

79. Кавалерский Г.М., Силин Л.Л., Донченко С.В., Костюков В.В. Дифференцированный подходк лечению переломов шейки бедренной кости у больных пожилого и старческого возраста // Медицинская помощь. - 2005. - № 1. - С. 26-28.

80. Кавалерский, Г.М. Двухэтапное лечение тяжелых открытых переломов голени / Г.М. Кавалерский [и др.] // Сборник тезисов IX съезда травматологовортопедов России. Саратов, 2010. - Т. 1. - С.155-156.

81. Каплан А.В. Повреждения костей и суставов .- М.: Медицина, 1979, 568 с

82. Каплунов, О.А. Чрескостный остеосинтез по Илизарову в травматологии и ортопедии / О.А.Каплунов. - М. : ГЭОТАР-МЕД, 2002. - 301 с.

83. Карлов А.В., Шахов В.П. Системы внешней фиксации и регуляторные механизмы оптимальной биомеханики. - Томск: СТТ, 2001. - С. 480.

84. Кассиль Г.Н. Химическая регуляция функций // Наука о боли. - 2-е изд., доп. - М.: Наука, 1975. - 400 с.

85. Климовицкий В. Г. Внутрисуставные переломы шейки бедренной кости у пациентов в возрасте до 50 лет (особенности механогенеза и лечения) / В. Г. Климовицкий, М. А. Канзюба, А. И. Канзюба // Травма. - 2008. - Т.9, № 3. - С. 304-309.

86. Клиника и лечение эндотоксикации при острых хирургических заболеваниях // В. В. Рыбачков, Э. В. Малофеева, И. А. Андреев и др. // Ярославль. - Издательство Ярославского медицинского института. -1986.-30с.

87. Ключевский В.В. Хирургия повреждений: Руководство для фельдшеров, хирургов и травматологов районных больниц. Изд.2-е- Рыбинск: изд-во ОАО «Рыбинский дом печати», 2004,-784c.

88. Ключевский, В.В. Лечение открытых переломов бедренной кости / В.В. Ключевский // Сборник тезисов IX съезда травматологов-ортопедов России. - Саратов, 2010. - Т. 1. C. 165 .

89.Кожахметов О.А. История развития внутрикостного остеосинтеза http://journal.ssmu.kz/index.php?statja=995\&lang=ru Опубликовано: 29-10-2014

90. Копысова В.А., Каплун В.А. Остеосинтез переломов у больных с множественными и сочетанными повреждениями // Новые технологии в медицине: тез. докл науч.-практ. конф. с междунар. участием. В 2-х ч. - Курган, 2000. - Ч. І. - С. 140-141.

91. Корнеев Г.Я. Кора надпочечников // В кн.: Физиология эндокринной системы. Л. : Наука, 1979. - С. 285-324.

92. Корнилов Н.В., Грязнухин Э.Г., Осташко В.И. Травматология: Краткое руководство для практических врачей. - СПб.: Гиппократ, 1999. - 240 с.

93. Корнилов Н.В. Травматология и ортопедия. Учебник. - СПб.: Гиппократ, 2001. - 468 с.

94. Корнилов Н.В., Шапиро К.И. Актуальные вопросы организации травматологоортопедической помощи населению // Травматология и ортопедия России. - 2002. - № 2. - C. 35-38. 
95. Костюшко А. В. Окислительный стресс при хирургической патологии / А. В. Костюшко, И. И. Кузьмин, Е. В. Маркелова, Е. А. Чагина // Политравма: диагностика, лечение и профилактика осложнений : материалы Всеросийской научно-практической конференции 28 - 30 сентября 2005, г. Ленинск-Кузнецкий. - Новосибирск, 2005. - с. 41.

96. Кривенко, С.Н. Чрескостный остеосинтез в лечении переломов костей предплечья / С.Н. Кривенко //Сборник тезисов IX съезда травматологов-ортопедов России. Саратов, 2010. - Т. 1. - С. 174-175.

97. Кувакин В.И. Ретроспективный анализ травматизма и состояния травматологоортопедической помощи населению на рубеже XX-XXI веков /В.И. Кувакин, А.Ж. Чёрный, Т.Н. Воронцова // Вестник российской военно-медицинской академии. - 2013. - № 3(43). - C. 1-5

98. Кулагин, В. К. Патологическая физиология травмы и шока / В. К. Кулагин. - Л.: Медицина, 1978. - 296 с.

99. Кулик В.И. Комплексное лечение открытых диафизарных переломов костей голени (экспериментально-клиническое исследование): дис. ... д-ра мед. наук в виде науч. докл. - СПб, 1992. - 53 с.

Кулик, В.И. Лечение диафизарных переломов плечевой кости на современном уровне / В.И. Кулик,И.Г. Беленький, Т.Б. Раенгулов// Травматология и ортопедия России. 2000. - №2/3. - С. 134.

100. Кульджанов Д. Лечение несращений переломов шейки бедра у молодых пациентов / Д. Кульджанов // Чаклинские чтения : материалы науч.-практ. конф. травматологовортопедов с междунар. участием. - Екатеринбург, 2011. - С. 51-52.

101. Купкенов Д.Э. Применение стержневых аппаратов при диафизарных переломах голени // Травматология и ортопедия России. - 2010. - № 2(56). - С.39-44.

102. Куфтырев Л.М., Борзунов Д.Ю. Полилокальный дистракционно-компрессионный остеосинтез при лечении больных с дефектами бедренной кости // Удлинение конечностей и замещение дефектов костей: материалы докл. I междунар., 5 респ. науч.-практ. конф. травматологовортопедов Крыма. - Ялта, 1996. - С. 56-57.

103. Куфтырев Л.М., Борзунов Д.Ю., Болотов Д.Д. Замещение обширных дефектов дистального конца бедренной кости методом чрескостного остеосинтеза // Современные проблемы медицины и биологии: материалы XXIX обл. науч.-практ. конф. - Курган, 1997. - С. 209-210.

104. Куфтырев Л.М., Борзунов Д.Ю., Петровская Н.В. и др. Новый подход к пластическому замещению обширных дефектов костей нижней конечности // Актуальные вопросы и перспективы развития многопрофильного лечебного учреждения: тез. докл. Всерос. науч. конф. Шиханы, 2001. - С. 238-240.

105. Куфтырев Л.М., Борзунов Д.Ю., Пожарищенский К.Э. и др. Минерализация дистракционных регенератов при полилокальном удлинении отломка большеберцовой кости // Материалы науч.практ. конф. врачей Курганской области. - Шадринск, 1999. - С. 35-37.

106. Куфтырев Л.М., Свешников А.А., Пожарищенский К.Э. и др. Репаративное костеобразование при замещении межсегментарных дефектов костей в области коленного сустава по данным радионуклидной диагностики и результатам костной денситометрии // Гений ортопедии, - 2000. - № 1. - С. 20-23.

107. Лавринович Т.С. и др. Липиды и свертывание крови после повреждения костей/ Т.С. Лавринович, М.Э. Лиепа, Л.И. Слуцкий. - Рига: Зинтане, 1979.- 190 с.

108. Лаврищева Г.И., Оноприенко Г.А. Морфологические и клинические аспекты репаративной регенерации опорных органов и тканей. - М.: Медицина, 1996. - 208 с.

109. Лазарев А. Ф. Особенности эндопротезирования тазобедренного сустава при переломах шейки бедренной кости / А. Ф. Лазарев, А. О. Рагозин, Э. И. Солод, М. Г. Какабадзе // Вестн. травматологии и ортопедии им. Н.Н. Приорова. 2003. № 2. С. 3-8.

110. Лазарев А.Ф., Солод Э.И., Рагозин А.О., Какабадзе М.Г. Лечение переломов проксимального отдела бедренной кости на фоне остеопороза // Вестн. травматол. и ортопед. им. Н.Н. Приорова. - 2004. - № 1. - С. 27-31.

111. Леонтьева, Н. В. Синдром эндогенной интоксикации / Н. В. Леонтьева, М. В. Белоцерковский ; под ред. Н. Н. Петрищева. - СПб. - 1998. - 48 с. 
112. Лирцман В. М. Проблема лечения переломов шейки бедра на рубеже столетий / В. М. Лирцман, В. И. Зоря, С. Ф. Гнетецкий // Вестн. травматологии и ортопедии им. Н.Н. Приорова. 1997. № 2. С. 12-19.

113. Логоша, С. А. Влияние углеводного рациона и физической нагрузки на активность супероксиддисмутазы и концентрацию диеновых конъюгатов в крови и цитозоле скелетной мышцы крыс/ С. А. Логоша, В. И. Морозов, В. А Рогозкин // Физиол. журнал. - 1996. - №2. - С.55 - 60.

114. Ломтатидзе Е. Ш. Комплексная оценка результатов хирургического лечения внутрисуставных переломов шейки бедренной кости / Е. Ш. Ломтатидзе, Д. В. Волченко [и др.] // Вестн. травматологии и ортопедии им. Н.Н. Приорова. 2005. № 3. С. $11-15$.

115. Лыжина, Е.Л. Сравнительный анализ оперативных методов лечения около- и внутрисуставных переломов и переломовывихов голеностопного сустава / Е.Л. Лыжина, Н.О. Каллаев, Т.Н. Калаев // Вестн. травматологии и ортопедии. им. Н.Н. Приорова. -2004. - № 1. - С. 32-35.

116. Львова, С. П. Влияние гипотермии и даларгина на перекисное окисление липидов в тканях крыс / С. П. Львова, Т. Ф. Горбунова, Е. М. Абаева // Вопр. мед. химии. - 1993. № 3. - С. 21 - 24 .

117. Лукьянова Л. Д. Об особенностях нарушений энергетического обмена при травматическом шоке и возможности их фармакологической коррекции/ Л. Д. Лукьянова, Н. Н. Михайлова, Д. В. Фоменко и др.// Бюлл. эксп. биол. и медицины. 2001. - № 9. - С. 263-267.

118.Лурия Е.А., Кузнецов С.А., Генкина Е.Н. и др. Образование костной ткани в органных культурах костного мозга человека // Бюл. эксперим. биол. и мед. - 1989. - Т. 107, № 5. - С. 593-595.

119. Макушин В.Д., Куфтырев Л.М., Симахина В.М. Лечение субтотального дефекта бедренной кости // Анн. травматол. и ортопед. - 1995. - № 2. - С. 45-47.

120. Малахова, М. Я. Эндогенная интоксикация как отражение компенсаторной перестройки обменных процессов в организме / М. Я. Малахова // Эфферентная терапия. - 2000. - № 4. - С. 3 - 14.

121. Малахова, М. Я. Эндогенная интоксикация как отражение компенсаторной перестройки обменных процессов в организме / М. Я. Малахова // Эфферентная терапия. - 2000. - № 4. - С. 3 - 14.

122. Марков А. А. Хирургическое лечение переломов шейки бедра / А. А. Марков, И. В. Кузнецов, К. С. Сергеев // Медицинская наука и образование Урала. 2007. № 6. С. 2830.

123. Мартель, И.И. Ошибки и осложнения при лечении больных с тяжелыми открытыми переломами костей голени по Илизарову / И.И. Мартель // Гений ортопедии. - 1996. № 2-3. - С. 93-94.

124. Мартель И.И. Метод чрескостного остеосинтеза в системе комплексного лечения больных с тяжелыми открытыми повреждениями нижних конечностей: автореф. дис.

... д-ра мед. наук. - Курган, 2006. - 39 с.

125. Масютин, В. А. Возможность оценки функциональных резервов организма в раннем посттравматическом периоде / В. А. Масютин, Р. В. Вашетко, Д. М. Широков // Трав., орт. России. - 1994.- № 6. - С. 86 - 95.

126. Масютин, В. А. Возможность оценки функциональных резервов организма в раннем посттравматическом периоде / В. А. Масютин, Р. В. Вашетко, Д. М. Широков // Трав., орт. России. - 1994.- № 6. - С. 86 - 95.

127. Матвеев А.Л. Лечение больных с диафизарными переломами костей голени со смещением отломков: дис. ... канд. мед. наук. - Самара, 1998. - 112 с.

128. Матвеев А. Л. Малоинвазивная хирургическая профилактика переломов шейки бедра у лиц пожилого возраста / [и др.] // Актуальные вопросы травматологии и 
ортопедии : материалы VIII съезда травматологов-ортопедов Узбекистана. Ташкент, 2012. С. 161-163.

129. Маттиас Эппле Биоматериалы и биоминерализация./Перевод с немецкого под ред. В.Ф.Пичугина, Ю.П.Шаркеева, И.А.Хлусова. Томск: издательство «Ветер», 2007. - 137c.

130. Мельцер Р. И. Биомеханические аспекты оперативного лечения переломов шейки бедра и их последствий / Р. И. Мельцер [и др.] // Современные методы остеосинтеза : сб. науч. тр. - Петрозаводск, 1994. - С. 4-6.

131. Меркулов В.Н., Дорохин А.И. К вопросу о диагностике и лечении замедленно срастающихся переломов длинных трубчатых костей у детей: Сб. научн. тр. «Актуальные вопросы детской травматологии и ортопедии» М., 2001,С.344-345.

132. Мизиев И.А. Наш опыт лечения переломов шейки бедренной кости канюлированными винтами // Мизиев И.А. [и др.] // Малоинвазивные технологии в травматологии - ортопедии и нейрохирургии: материалы Всероссийской научно - практической конференции - Саратов 2013. - С. 34 35.

133. Миронов С.П., Гинцбург А.Л., Еськин Н.А. и др. Остеоиндуктивные имплантаты на основе биокомпозитных матриксов и рекомбинантных костных морфогенетических белков (RHBMP). Состояние вопроса, перспектива применения в травматологии и ортопедии // Cб. тез. IX съезда травматологовортопедов. - Саратов, 2010. - Т. III. - С. 1122-1123.

134. Молодцов А.Н., Родионов А, Б, Лечение переломов костей предплечья в условиях детского хирургического центра: Сб. научн. тр. «Актуальные вопросы детской хирургия перспективы развития» Хабаровск, 2001, С, 106-108

135. Мороз В. В. Показатели липидного обмена у больных в критических состояниях / В. В. Мороз, Л. В. Молчанова, Л. Н. Щербакова, Кравченко и др. // Анестезиология и реаниматология. - 2001. - № 6. - С. 4 - 6.

136. Мурзабеков И. А. Исходы лечения медиальных переломов шейки бедренной кости у больных пожилого и старческого возраста при разных методах остеосинтеза / И. А. Мурзабеков // Вестн. травматологии и ортопедии им. Н.Н. Приорова. - 2006. - № 3. - С. 22-26

137. Мюллер М,Е. Руководство по внутреннему остеосинтезу /М,Е.Мюллер, М.А. Аллговер, Р. Шнейдер, Х. Виллингер.-М., 1996.-С.522-530.

138. Наточин, Ю. В. Сукцинатдегидрогеназа в реабсорбирующих натрий сегментах нефрона позвоночных / Ю. В. Наточин, Т. В. Крестинская // Физиол. журн. СССР. 1961. - №3 - C. 388 - 392.

139. Немков В.А., Каравашкин Б.К., Либерман С.Б. Чрескостные компрессионнодистракционные аппараты с точки зрения механики и сопротивления материалов // Теорет.и практ. аспекты чрескост. компресс. и дистракц. остеосинтеза. - М.,1977. C.45-50.

140. Немченко, Н. С. Метаболические основы патогенеза тяжелой сочетанной травмы / Н. С. Немченко, А. В. Гончаров, М. Б. Борисов // Вестник хирургии. - 2001. -№5.-С. 114-119.

141. Немченко, Н. С. Постагрессионный обмен веществ при тяжелой механической травме / Н. С. Немченко, И. А. Ерюхин, В. Ю. Шанин // Вест. хирургии. - 1991. - № 4. C. 53-57.

142. Николайчик В. В. Средние молекулы - образование и способы определения / В. В. Николайчик, В. В. Кирковский, В. М. Моин и др. // Лабораторное дело. - 1989. - № 8. C. 99-102. 
143. Николайчук Е.В. Клинико-физиологическое обоснование применения гипербарической оксигенации при лечении больных с закрытыми переломами костей голени: автореф. дис. ... канд. мед. наук. - Курган, 2004. - 23 с.

144. Осипян И.А., Айвазян В.П. Применение костного матрикса с целью стимуляции остеогенеза в условиях раневой инфекции // Ортопедия, травматология и протезирование. - 1985. - № 1. - С. 45-46.

145. Особенности изменений функции почек при политравмах у детей / Б. Х. Хамидов, П. С. Джалилов, И. С. Каратаев, Н. Н. Золотова // VII съезда травматологов ортопедов России : тезисы докладов. - Новосибирск. - 2002. - Том 1. - С.494 - 495.

146. Перекисное окисление липидов и содержание средних молекул при операциях на сердце с искусственным кровообращением / М. Ю. Андрианова, М. В. Палюлина, Е. А. Кукаева, В. И. Мильчаков // Анестезиология и реаниматология. - 2001. - № 2. - С. 33 35.

147. Петровская Т.С. Биоматериалы и имплантаты для травматологии и ортопедии. / Петровская Т.С., Шахов В.П., Верещагин В.И., Игнатов В.П. // Томск: Издательство Томского политехнического университета, 2011. 307с.

148. Пичхадзе, И.М. Лечение переломов длинных костей конечностей методом чрескостного остеосинтеза на основе биомеханической концепции / И.М. Пичхадзе [и др.] // Вестн. травматологии и ортопедии. им. Н.Н. Приорова. - 2006. - № 4. - С. 12-17.

149. Плаксейчук А.Ю. Сравнительный анализ современных методов замещения дефектов длинных трубчатых костей // Амбулаторная травматолого-ортопедическая помощь: тез. докл. Всерос. науч.-практ. конф. В 2-х ч. - СПб.-Йошкар-Ола, 1994. - Ч. 2. - C. $16-17$.

150. Повзун, С. А. Роль фактора некроза опухолей в патогенезе инфекционновоспалительного эндотоксикоза / С. А. Повзун // Вестник хирургии. - 1991. - № 7 - 8. C. 127-132.

151. Попова Л.А. Актуальные вопросы медико-социальной экспертизы и реабилитации инвалидов с последствиями травм опорно-двигательной системы /Л.А. Попова, Т.А. Волосатова // Гений ортопедии. - 2005. - № 4. - С.52-56

152. Попков А.В., Попков Д.А. Биоактивные имплантаты в травматологии и ортопедии. - Иркутск: НЦРВХ СО РАМН, 2012. - 438 с.

153. Попков А.В. Монолатеральный остеосинтез при диафизарных переломах плечевой кости /Попков А.В., Шелепов А.В., Девятых Р.В., Попков Д.А.// Гений ортопедии, 2015,№3, с.67-69.

154. Попов В.П., Здрелько В.П., Трухачев И.Г., Попов А.В. Осложнения при накостном остеосинтезе у больных с переломами длинных трубчатых костей. Гений ортопедии, 2014, №2, c. 5-9.

155. Прокопьев А.Н. Особенности и исходы лечения больных с закрытыми диафизарными переломами костей голени в зависимости от тяжести первоначальной травмы: автореф. дис. ... канд. мед. наук. - Курган, 2003. - 22 с.

156. Росков Р. В. Травма, травматизм. Последствия травм конечностей, показания к ортезированию: учеб. пособие/Р.В. Росков, А. О. Андриевская, А. В. Смирнов; Санкт-Петербург. ин-т усовершенствования врачей-экспертов [и др.]. - Изд. 2-е, перераб. и доп.. - СПб., 2009. - 180 с.

157. Родионов И.В., Бутовский К.Г. Получение биосовместимых морфологически гетерогенных покрытий на стальных остеофиксаторах воздушно-термическим оксидированием / Матер. Всеросс. науч.-практич. конф. «Новые технологии создания и применения биокерамики в восстановительной медицине». - Томск: Изд-во ТПУ, 2007. - С. 103-108.

158. Родионов И.В., Бутовский К.Г. Структурно-функциональные характеристики термических и электрохимических оксидных биопокрытий медицинских костных имплантатов / Materiały II Międzynarodowej naukowi-praktycznej konferencji 
«Perspektywiczne opracowania nauki i techniki - 2007». Przemyśl, Polska: Nauka i studia. Tym 12. - S. 15-19.

159. Родионов И.В., Бутовский К.Г., Анников В.В., Хапрова Т.С. Фазовый состав и коррозионное поведение биопокрытий чрескостных фиксаторов из стали 12Х18Н9Т, полученных термическим оксидированием / Сб. докл. 2-го Междунар. научно-техн. симп. «Наноструктурные функциональные покрытия и материалы для промышленности» Харьковской нанотехнологической ассамблеи - 2007. Т.1. Наноструктурные материалы. - Харьков, 2007. - С. 134-138.

160. Ролик А.В., Корж Н.А. Внутрисуставные переломы шейки бедренной кости (проблемы, хирургическое лечение) // Ортопедия, травматология и протезирование. 1997. - № 2. - С. 20-23.

161. Рушай А.К., Кривенко С.М., Борзих О.В. Современные информационные технологии в преподавании вопросов лечения открытых переломов // Укр. журн. телемед. и мед. телемат. - 2004. - Т. 2, № 1. - С. 8-11.

162. Санникова Е.В. Эпидемиология травм и пути повышения качества и эффективности лечения пострадавших: автореф. дис. ... канд. мед. наук. - СПб., 1999. $-20 \mathrm{c}$.

163. Саймон Р. Р. Неотложная травматология и ортопедия: верхние и нижние конечности/ Р. Р. Саймон, С. С. Шерман, С. Дж. Кенигснехт; пер. с англ. под общ. ред. Л. К. Михайловой. - М.: Бином; СПб.: Диалект, 2012. - 680 с

164. Сайпиев А. С. Лечение медиальных переломов шейки бедренной кости компрессирующими винтами системы АО в ургентной травматологии / А. С. Сайпиев [и др.] // Актуальные вопросы травматологии и ортопедии : материалы VIII съезда травматологов-ортопедов Узбекистана. Ташкент, 2012. С. 179-181.

165. Сергеев С.В. Происхождение остеосинтеза. Внутрикостный остеосинтез : Лекция / РУДН, Москва. Режим доступа: www.otcf.ru/?page=lecture5, свободный

166. Серкова Е.В. Медико-социальные аспекты травматизма и пути совершенствования системы оказания медицинской помощи пострадавшим с переломами костей конечностей(Комплексное социально-эпидемиологическое исследование на примере Курганской области). Дис. Канд. мед. наук. - Екатеринбург, 2011. - 203с.

167.Свешников А.А., Офицерова Н.В., Попков А.В. и др. Концентрация остеотропных гормонов и циклических нуклеотидов в сыворотке крови при автоматическом удлинении бедра // Гений ортопедии. - 1996. - № 2-3. - С. 60.

168. Скороглядов А.В. Возможности обезболивания и иммобилизации при повреждениях и заболеваниях опорно-двигательного аппарата /А.В.Скороглядов, А.В.Бутров, Д.А.Магдиев, Е.Н.Кондрашенко, М.А.Страхов// Учебное пособие. М., «ООО Сам Полиграфист». - 2012.- 248 с.

169. Смирнов А.С. Влияние поверхностных характеристик внутрикостных имплантатов из титана на остеогенез (Обзор литературы) // Новое в стоматологии. - 2000. - № 8. C. 25-29.

170. Соков, С. Л. Информационное моделирование адаптационных синдромов травматических стресс - ситуаций / С. Л. Соков, Л. П. Соков // Вестник РУДН. Серия Медицина. - 1999. - № 1.- С. 91 - 99.

171. Соловьёв В.А., Давыдов Б.Н., Сулейманов А.Б., Шинкаренко Т.В. Морфологический анализ костной ткани после применения биокомпозиционных материалов в новом методе периостеопластики // Институт стоматологии. - 2002. № $1 .-$ C. $43-46$.

172. Соломин, Л.Н. Основы чрескостного остеосинтеза аппаратом Г.А. Илизарова / Л.Н. Соломин. - СПб. : Морсар АВ, 2005. - 544 с.

173. Состояние процессов перекисного окисления липидов при энтеральной коррекции экспериментальной кровопотери / С. Б. Матвеев, В. В. Марченко, Т. С. Попова и др. // Вопр. мед. химии. - 1999. - № 2. - С. 140 - 144. 
174. Стадников, В.В. Мотивация выбора метода лечения и вида остеосинтеза при оскольчатых переломах бедра / В.В. Стадников, А.С. Кузнецова, А.П. Барабаш // Гений ортопедии. - 2004. - № 4. - С. 41-45.

175. Субботин, А. В. Сравнительный анализ информативности лабораторных показателей оценки тяжести синдрома эндогенной интоксикации при клещевом энцефалите / А. В. Субботин, Н. В. Чебаненко, С. Ф. Зинчук // Сибирдкий медицинский журнал. - 2001. - № 1. - С. 27 - 32.

176. Сысенко, Ю.М. Возможности чрескостного остеосинтеза по Илизарову при лечении закрытых диафизарных переломов длинных трубчатых костей верхних конечностей: / Ю.М. Сысенко [и др.] //Гений ортопедии. - 1998. - №4. - С. 87-91.

177. Сысенко Ю.М. Способ лечения оскольчатого перелома бедренной кости / Ю.М. Сысенко, С.И. Новичков // Гений ортопедии. - 2001. - № 4. - С. 114-117.

178. Татарников М.А. Основные этапы и перспективы реформирования российского здравоохранения // Главврач. - 2006.- № 12.- С. 29-39.

179. Твердохлебов С.И., Игнатов В.П., Степанов И.Б., Сивин Д.О., Петлин Д.Г. Гибридный метод формирования биокомпозитов на поверхности имплантатов из нержавеющей стали // Биотехносфера. - 2012. - № 5-6 (23-24). - С. 63-69.

180. Твердохлебов С.И., Шестериков Е.В., Мальчихина А.И. Особенности формирования кальций-фосфатных покрытий методом ВЧ-магнетронного напыления на имплантатах // Известия Томского политехнического университета. - 2012. - Т. 320. - № 2. - С. 73-79.

181. Тихилов, Р.М. Состояние травматизма и ортопедической заболеваемости взрослого населения Санкт-Петербурга в 2009-2011 гг. и работа травматолого-ортопедической службы города / Р.М. Тихилов [и др.] // Травматология и ортопедия России. - 2012. № 4. - С.110-119.

182. Тимошенко, О. П. Стресс и его роль в генезе ортопедических заболеваний / О. П. Тимошенко // Орт., травмат. и протезирование. - 1997. - № 3. - С. 23 - 24.

183. Ткаченко С.С., Демьянов В.М., Борисенко В.Н. и др. Показания к применению современных методов лечения закрытых диафизарных переломов длинных трубчатых костей // Ортопедия и травматология. - 1975. - № 5. - С. 1-6.

184. Тодрия Т.В. Пролиферативный потенциал КОЕс из костного мозга тимэктомированных мышей // Бюл. эксперим. биол. и мед. - 1992. - Т. 114, № 8. - С. 208-209.

185. Травматическая болезнь/ Под ред. И.И. Дерябина, О.С. Насонкина. - Л.: Медицина, 1987. - $303 \mathrm{c}$.

186. Травматология. Национальное руководство./ Под редакцией Г.П.Котельникова и С.П.Миронова. - М., «ГЭОТАР-Медиа». -2008 - 803 с.

187. Труханов, А. И. Компьютерные системы экспресс- диагностики - наиболее информативный метод оценки уровня здоровья населения / А. И. Труханов // Вопросы профилактической медицины в регионах Крайнего Севера : сборник тезисов 4-ой Республиканской научно-практической конференции. - 2006. - С 176 - 177.

188. Уразгильдеев, З.И. Комплексное одноэтапное лечение несросшихся переломов, ложных суставов и дефектов длинных костей конечностей, осложненных остеомиелитом / 3.И. Уразгильдеев [и др.] // Вестн. травматологии и ортопедии. им. Н.Н. Приорова. -2002. - № 4. - С. 33-38.

189. Усмонов Ф. М. Результаты эндопротезирования тазобедренного сустава после переломов и ложных суставов шейки бедренной кости / Ф. М. Усмонов [и др.] // Илизаровские чтения : материалы науч.-практ. конф. с междунар. участием, посвящ. 90-летию со дня рождения Г. А. Илизарова, 60-летию метода Илизарова, 40-летию РНЦ "ВТО". - Курган, 2011. - С. 367.

190.Устьянцев В.И. Реабилитация инвалидов с последствиями травм и голени посредством чрескостного остеосинтеза // Мед.-соц. эксп. и реабил. - 2006. - № 4. - С. 13-17 . 
191. Ушаков С.А. Лечение пострадавших с переломами вертельной области бедренной кости методом интрамедуллярного остеосинтеза в условиях городской больницы: автореф. дис. ... канд. мед. наук. - Курган, 2009. - 23 с.

192. Фадеев Д.И. Ранний металлоостеосинтез при автодорожной политравме // Диагностика и лечение политравм: материалы IV пленума Рос. ассоциации ортопедовтравматологов. - Ленинск-Кузнецкий, 1999. - С. 219-221.

193. Филиппенко, В. А. Ошибки и осложнения при эндопротезировании тазобедренного сустава и их профилактика / В. А. Филиппенко, В. А. Танькут, С. Х. Масандика // Вестн. травматол. и ортопед.им. Н. Н. Приорова. - 1998. - № 3. - C. 37-40.

194.Фриденштейн А.Я. Стволовые остеогенные клетки костного мозга // Онтогенез. - 1991. - Т. 22, № 2. - С. 189-197.

195. Хайдаров Н.С., Ибрагимов С.Х., Акромов И.Ш., Акромов В.Р. Результаты лечения диафизарных переломов костей голени // Актуальные проблемы травматологии и ортопедии: тез. материалов науч.-практ. конф. - Карши, 2000. - С. 39-40.

196. Хайитбоев Б. М. Выбор метода остеосинтеза при переломах шейки бедренной кости у лиц пожилого возраста / Б. М. Хайитбоев, Н. Т. Юсупов, Р. А. Хашимов // Актуальные вопросы травматологии и ортопедии : материалы VIII съезда травматологов-ортопедов Узбекистана. - Ташкент, 2012. - С. 232-233.

197. Ханапияев У.Б. Влияние иммуномодули-на на иммунный статус больных с открытыми переломами костей голени / У.Б. Ханапияев, М.С. Асамов, В.У. Шодиев // Ортопедия, травматолгия и протезирование. 2000. - № 3. - С. 82-84.

198. Ц Цыбуляк Г.Н. Травма. Боль. Анестезия. - М.: Медицина, 1994. - 224 с.

199. Чернега, Л. И. Роль противоперекисной системы эритроцитов в патогенезе нейроциркуляторной дистонии у ликвидаторов аварии на ЧАЭС / Л. И. Чернега // Вест. научных иссл. - 1997. - № 6-7. - С. 11 - 14.

200. Чернега, Л. И. Роль противоперекисной системы эритроцитов в патогенезе нейроциркуляторной дистонии у ликвидаторов аварии на ЧАЭС / Л. И. Чернега // Вест. научных иссл. - 1997. - № 6-7. - С. 11 - 14.

201. Шапошников Ю.Г., Мусса М., Саркисян А.Г. и др. Замещение обширных дефектов длинных костей с помощью би- и полилокального дистракционно-компрессионного остеосинтеза // Хирургия. - 1990. - № 9. - С. 3-6.

202. Шапошников Ю.Г. Система оценки тяжести травм (состояние и перспективы проблемы) / Ю. Г. Шапошников, Г. И. Назаренко, В. М. Розинов и др. // Ортопедия, травматология и протезирование. - 1990. № 4. С. 1-5.

203. Швед С.И. Роль чрескостного остеосинтеза по Илизарову в системе реабилитации травматологических больных с множественными переломами костей / С. И. Швед, Ю.

М. Сысенко, С. И. Новичков, Л. В. Мальцева // Гений ортопедии. - 2000. - № 2. - С.5-9.

204. Швед С.И. Лечение больных с множественными переломами костей нижних конечностей методом чрескостного остеосинтеза по Илизарову / С.И.Швед, А.Г. Карасев, Т.И. Долганова, А.А. Свешников // Гений ортопедии. - 2006. - № 4. - С. 7578.

205. Шевцов В.И. Швед С.И., Сысенко Ю.М. Чрескостный остеосинтез при лечении оскольчатых переломов. - Курган, 2002. - 331 с.

206. Шестериков Е.В. Методы и оборудование для формирования гибридных биологически совместимых покрытий на имплантатах для хирургии / Дис... к.т.н. Томск, 2012.

207. Шигарев В.М. Закрытый чрескостный остеосинтез по Илизарову при переломах шейки бедренной кости. Дис. ... канд.мед.наук: 14.00.22 /Шигарев Вениамин Массимович -Пермь, 1988.- 164c.

208. Шигарев В.М. Чрескостный остеосинтез по Илизарову при лечении переломов и ложных суставов шейки бедренной кости /В.М. Шигарев, Д.И. Шахматов// Материалы 
VI съезда травматологов ортопедов СНГ.- Тез.докл.- Ярославль, 1993.-14-17 сентября. C. 108-109

209. Шрейнер А.А. К проблеме репарации краевых диафизарных дефектов кости (экспериментальное исследование) // Анн. травматологии и ортопедии. - 1995. - № 2. - С. 27-29.

210. Шутов Р.Б. Оперативное удлинение врожденно укороченной голени автоматическим дистрактором с применением интрамедуллярного армирования спицами с гидроксиапатитным покрытием: автореф. Дис.канд. мед. наук. - Курган, 2009. -23 c.

211. Щепин О.П., Тищук Е.А. Проблемы демографического развития России // Экономика здравоохр. - 2005. - № 3 (92). - С. 5-8.

212. Экстренное оперативное лечение больных пожилого и старческого возраста с переломами проксимального отдела бедренной кости / А.В.Войтович, И.И.Шубняков, А.Б.Аболин, С.Г. Парфеев // Травматология и ортопедия России. - 1996. - № 3. - С. 32-33.

213. Эндотоксикоз как проблема клинической хирургии / И. А. Ерюхин, О. С. Насонкин, Б. В. Шашков, В. Ф. Лебедев // Вестник хирургии. - 1989. - № 3. - С. 3 -7.

214. Эндотоксикоз при тяжелой сочетанной травме / И. А. Ерюхин, С. В. Гаврилин, Н. С. Немченко и др. // Вестник хирургии. - 2001. - № 5. - С. 120 - 124.

215. Эринле, Р.М. Сравнительная оценка различных способов остеосинтеза переломов длинных трубчатых костей / Р.М. Эринле, А.В. Рак, С.А. Линник,Г.П. Салдун. // Травматология и ортопедия России. - 1996. - №5. - С. 22-23.

216. Albrektsson T., Johansson C. Osteoinduction, osteoconduction and osseointegration // Eur. Spine J. - 2001. - V. 10, suppl. 2. - P. 96-101.

217.Anselme K., Noel B., Hardouin P. Human osteoblast adhesion on titanium alloy, stainless steel, glass and plastic substrates with same surface topography // J. Mater. Sci. Mater. Med. - 1999. - Vol. 10. - P. 815-819.

218. Ateschrang A, Dittel KK. Osteosynthetically-treated intracapsular femoral neck fractures // Zentralbl Chir. 2007 Feb;132(1):44-8.

219. Barrere F., van der Valk C.M., Meijer G. et al. Osteointegration of biomimetic apatite coating applied onto dense and porous metal implants in femurs of goats // J. Biomed. Mater. Res. - 2003. - Vol. 67. - P. 655-665.

220. Bassiony, A.A. Infected non-union of the humerus after failure of surgical treatment: management using the Orthofix external fixator / A.A. Bassiony [et al.] //Ann. Acad. Med. Singapore. - 2009. - Vol. 38, N 12. - P.1090-1094.

221.Bayrakter H.H., Morgan E.F., Niebur G.L. et al. Comparison of the elastic and yield properties of human femoral trabecular and cortical bone tissue // J. Biomech. - 2004. - Vol. 37. - P. 27-35.

222. Biochemical and antioxidant changes in plasma and erythrocytes of pentathlon horses before and after exercise / N. Balogh, T. Gaal, P.S. Ribiczeyne et al. // Vet. Clin. Pathol. 2001. - v. 30. - № 4. - P. 214-218.

223. Bjørgul K, Reikerås O. Outcome of undisplaced and moderately displaced femoral neck fractures // Acta Orthop. 2007 Aug;78(4):498-504.

224. Bone LB, Johnson KD, Weigelt J, Scheinberg R. Early versus delayed stabilization of femoral fractures: a prospective randomized study. 1989. Clin Orthop Relat Res. 2004 May;(422):11-6.

225. Bonfield W., Wang. M., Tanner K.E. Interfaces in analogue biomaterials // Acta. Mater. 1998. - № 46 (7). - P. 2509-2518.

226. Bowman EN, Mehlman CT, Lindsell CJ, Tamai J. Nonoperative treatment of bothbone forearm shaft fractures in children: predictors of early radiographic failure. J Pediatr Orthop. 2011 Jan-Feb;31(1):23-32.

227. Boyd A.R., Duffy H., McCann R. The Influence of argon gas pressure on co-sputtered calcium phosphate thin films // Nucl. Instrum. Methods Phys. Res. Sect. B. - 2007. - V. 258. - N. 2. - P. 421-428. 
228. Bozic, K. Pain in the total hip area / K. Bozic, H. E. Rubash // Clin. Orthop. - 2004. - N 420. - P.18-25.

229. Bran G.M., Stern-Straeter J., HoËrmann K., Riedel F., Goessler U. R. Apoptosis in bone for tissue engineering // Arch. Med. Res. - 2008. - V. 39. - P. 467-482.

230. Bull S.J. Failure modes in scratch adhesion testing // Surf. Coat Technol. - 1991. - Vol. 50. - P. 25-32.

231. Bullock R., Landolt H., Axwell W.L., Fujisawa H. Massive astrocytic swelling in response to extracellular glutamate - a possible mechanism for post traumatic brain swelling? Acta Neurochirurgica. 1994; Vol. 60:465-7.

232. Butt MF, Dhar SA, Gani NU, Farooq M, Mir MR, Halwai MA, Kangu KA, Mir BA, Kawoosa AA. Delayed fixation of displaced femoral neck fractures in younger adults // Injury. 2008 Feb;39(2):238-43. Epub 2008 Jan 31.

233. Capo, J.T. External fixation of distal radius fractures: effect of distraction and duration / J.T. Capo [et al.] // J.Hand Surg. - 2009. -Vol. 34-A, N 9. - P. 1605-1611.

234. Catagni M.A. Upgrade of the Ilizarov method // Eur. Instruct. Course Lectures. - 1999. - Vol. 4. - P. 152158.

235. Chang WH. Cerebrospinal fluid lactate, acid-base and gases unbalance in severe head injuryZhonghua Wai Ke Za Zhi. 1993 Dec;31(12):759-62. Chinese. PMID: 8033710 [PubMed - indexed for MEDLINE]

236. Chavez Moreno J., Bickhardt K. Demonstration of tissue lesions after intramuscular injection by determination of creatinekinase in blood // Dtsch. Tierarztl. Wochenschr. 1997. - v. 104. - № 12. - P. 512-515.

237. Chubzicki R. Bestimmung des Fettgehaltes im Blut bie Eingriffen am Knochensystem// Arch. Orthop., Unfall-Chir. - 1958. - v. 49. - № 5. - P. 544-548.

238. Clausen T, Khaldi A, Zauner A, Reinert M, Doppenberg E, Menzel M, Soukup J, Alves OL, Bullock MR. Cerebral acid-base homeostasis after severe traumatic brain injury. // J Neurosurg. 2005 Oct;103(4):597-607.

239. Clemens J.A.M., Wolke J.G.C., Klein C.P., de Groot K. Fatigue behavior of calcium phosphate coatings with different stability under dry and wet conditions // J. Biomed. Mater. Res. - 1999. - Vol. 48. - P. 741-748.

240. Cooley D.R., van Dellen A.F., Burgess J.O., Windeler S. The advantages of coated titanium implants prepared by radiofrequency sputtering from hydroxyapatite // J. Prost. Dent. - 1992. - V. 67. - P. 93-100.

241. Cuthbertson D.P. Alterations in metabolism following injury // Brit. J. Acc. Surg. - 1998. - v. 11. - № 3. - P. 175-189.

242. Czerny F, Linhart W, Rueger JM, Sommerfeldt D, Pannike A.Forearm fractures in children. Unfallchirurgie. 1994 Aug;20(4):203-10.

243. Day J.S., Ding M., Bednarz P. et al. Bisphosphonate treatment affects trabecular bone apparent modulus through micro-architecture rather than matrix properties // J. Orthop. Res. - 2004. - Vol. 22. - P. 465-471.

244. Dhammi IK, Singh S, Jain AK. Displaced femoral neck fracture in children and adolescents: closed versus open reduction--a preliminary study // J Orthop Sci. 2005;10(2):173-9.

245. Dhert W.J.A., Klein C.P.A.T., Jansen J.A. et al. A histological and histomorphometrical investigation of fluorapatite, magnesiumwhitlockite and hydroxylapatite plasma sprayed coatings in goats // J. Biomed. Mater. Res. - 1993. - Vol. 27. - P. 127-138.

246. Dorozhkin S.V. Biocomposites and hybrid biomaterials based on calcium orthophosphates. // Biomatter. - 2011. - V. 1. - P. 3-56.

247. Dorozhkin S.V. Calcium orthophosphates in nature, biology and medicine. // Materials. 2009. - V. 2. - P. 399-498.

248. Early increases in blood lactate following injury / T. J. Coats, J.E. Smith, D. Lockey et al. // J. R. Army Med. Corps. - 2002. - v. 148. - № 2. - P. 140-143. 
249. Egdahl RH First annual Arnar-Stone lecture: The importance of the endocrine and metabolic responses to shock and trauma / R.H. Egdahl, M.M. Meguid, F..Aun // Crit. Care Med. - 1977. - Nov-Dec; Vol. 5, No 6. - P. 257-263. PMID: 412644.

250. Eismann EA, Parikh SN, Jain VV.Rereduction for Redisplacement of Both-

Bone Forearm Shaft Fractures in Children. J Pediatr Orthop. 2015 Apr 3.

251. Enocson A, Tidermark J, Tornkvist H, Lapidus LJ. Dislocation of hemiarthroplasty after femoral neck fracture: better outcome after the anterolateral approach in a prospective cohort study on 739 consecutive hips // Acta Orthop. 2008 Apr;79(2):211-7.

252. Fassier-Duval femoral rodding in children with osteogenesis imperfecta receiving bisphosphonates: functional outcomes at one year / Ruck J, Dahan-Oliel N, Montpetit K, Rauch F, Fassier F. // J Child Orthop. - 2011. - Vol. 5(3). - P. 217-224.

253. Ferrier J., Ross S.M., Kanehisa J., Aubin J.E. Osteoclasts and osteoblasts migrate in opposite directions in response to a constant electrical field // J. Cell. Physiol. - 1986. V. 129. - Iss. 3. - P. 283-288.

254. Fiévez EF, Hanssen NM, Schotanus MG, van Haaren EH, Kort NP. Stress fracture of the femoral neck in a child: a case report // J Pediatr Orthop B. 2012 Aug 29. [Epub ahead of print].

255. FitzSullivan E, Salim A, Demetriades D, Asensio J, Martin MJ. Serum bicarbonate may replace the arterial base deficit in the trauma intensive care unit. // Am J Surg. 2005 Dec;190(6):941-946.

256. Fogagnolo F., Kfuri M.Jr., Paccola C.A. Intramedullary fixation of pertrochanteric hip fractures with the short AO-ASIF proximal femoral nail // Arch. Orthop. Trauma Surg. 2004. - Vol. 124, № 1. - P. 31-37.

257. Forsh DA, Ferguson TA. Contemporary management of femoral neck fractures: the young and the old // Curr Rev Musculoskelet Med. 2012 Sep;5(3):214-21.

258. Franklin CC, Wren T, Ferkel E, Arkader A. Predictors of conversion from conservative to operative treatment of pediatric forearm fractures. J Pediatr Orthop B. 2014

Mar;23(2):150-4.

259. Friedman A. Plasma Chemistry. - Cambridge University Press, 2008, 125-135.

260. Friess W. Collagen-biomaterial for drug delivery // Eur. J. Pharm. Biopharm. - 1998. Vol. 45, N 2. - P. 113-136.

261. Fujibayashi S, Osteoinduction of porous bioactive titanium metal / Fujibayashi S, Neo M, Kim H M, Kokubo T \& Nakamura T // Biomaterials. - 2004, Vol. 25. - P. 443-450.

262. Garden R.S. Low-angl fixation in frakturees of the femoral neck. J. Bone Joint Surg. 1961; 43B: 647.

263. Giannoudis PV, Veysi VT, Pape HC, Krettek C, Smith MR. When should we operate on major fractures in patients with severe head injuries? Am J Surg. 2002 Mar;183(3):261-7.

264. Goodwin RC, Kuivila TE. Pediatric elbow and forearm fractures requiring surgical treatment. Hand Clin. 2002 Feb;18(1):135-48.

265. Gordan G.S. Recent progress in calcium metabolism: clinical application // Calif Med. - 1971 May; Vol.114, No 5. - P. 28-43. Review. PubMed PMID: 4932406; PubMed Central PMCID: PMC1501987.

266. Gross K.A., Ray N., Rokkum M. The contribution of coating microstructure to degradation and particle release in hydroxyapatite coated prostheses // J. Biomed. Mater. Res. - 2002. - Vol. 63. - P. $106-114$

267. Gulati SC, Sood SC, Bali IM, Kak VK. Cerebral metabolism following brain injury. I. Acid-base and pO2 changes.Acta Neurochir (Wien). 1980;53(1-2):39-46. PMID: 6776784 [PubMed - indexed for MEDLINE]

268. Gulsen M., Atesalp S., Cinar M. et al. Treatment of femoral bone defects with Ilizarov methods: Turkish experience // 2-nd Int. Meeting of the A.S.A.M.I.: Abtracts book. - Rome, 2001. - P. 101-102. 
269. Guo X.E., Goldstein S.A. Is trabecular bone tissue different from cortical bone tissue? // Forma. - 1997. Vol. 12. - P. 185-196.

270. Gustilo R.B., Mendoza R.M., Williams D.N. Problems in management of type III (severe) open fractures; A new classification of type III open fractures. J. Trauma 24:742, 1984.

271. Hacking S.A., Harvey E.J., Tanzer M. et al. Acid-etched microtexture for enhancement of bone growth into porous-coated implants // J. Bone Jt Surg. Br. - 2003. - Vol. 85. - P. 11821189.

272. Heikkinen T, Wingstrand H, Partanen J, Thorngren KG, Jalovaara P. Hemiarthroplasty or osteosynthesis in cervical hip fractures: matched-pair analysis in 892 patients // Arch Orthop Trauma Surg. 2002 Apr;122(3):143-7. Epub 2001 Sep 7.

273. Helfet D.L. $t$ t al. AO philosophy and principles of fracture managmentits evolution and evaluatijn. J. Bone Joint Surg. Am. 85- A:1156, 2003.

274. Hellinger J. Aussere Fixationen - Indikationen, Ergebnisse (Ubersicht) //Beitr.Orthop. 1983.- H. 11. - S. 611.

275. Hench L.L. Bioceramics // J. Amer. Ceram. Soc. - 1998. - Vol. 81, № 7. - P. 1705-1728.

276. Henzler D, Cooper DJ, Mason K. Factors contributing to fatal outcome of traumatic brain injury: a pilot case control study.Crit Care Resusc. 2001 Sep;3(3):153-7.

277. Hernigou P., Beaujean F. Treatment of osteonecrosis with autologous bone marrow grafting // Clin. Orthop. - 2002. - № 405. - P. 14-23.

278. Huang S., Terstappen L.W. Formation of hemopoietic microeniviroment and hemopoietic stem cells from single human bone marrow cells // Nature. - 1992. - Vol. 360, № 6406. - P. 745-749.

279. Intestinal ischemia-reperfusion and plasma enzyme levels / F. Caglayan, O. Caglayan, E. Gunel et al. // Pediatr. Surg. Int. - 2002. - v. 18. - № 4. - P. 255-257.

280. Iorio R, Healy WL, Appleby D, Milligan J, Dube M. Displaced femoral neck fractures in the elderly: disposition and outcome after 3- to 6-year follow-up evaluation // J Arthroplasty. 2004 Feb;19(2):175-9.

281. Itadera E, Ichikawa N, Yamanaka N, Ohmori T, Hashizume H. Femoral neck fractures in older patients: indication for osteosynthesis // J Orthop Sci. 2003;8(2):155-9.

282. Jansen J.A., van der Waerden J.P.C.M., Wolke J.G.C., de Groot K. Histologic evaluation of the osseous adaptation to titanium and hydroxylapatite-coated implants // J. Biomed.

Mater. Res. - 1991. - Vol. 25. - P. 973-989.

283. Jenkins R.R. Exercise, oxidative stress and antioxidants: a review // Sports Nutrition. 1993. - v. 3.- № 4. - P. 356-375.

284. Kanczler J.M., Oreffo R.O. Osteogenesis and angiogenesis: the potential for engineering bone // Eur. Cell Mater. - 2008. V. 15. - P. 100-114.

285. Karapinar, H. Ilizarov augmentation in the treatment of humeral shaft nonunions developing after failed intramedullary nailing / H. Karapinar [et al.] //Eklem. Hastalik Cerrahisi. - 2010. - Vol. 21, N 3. -P. 142-146.

286. Khan, N.Q. Referral patterns of hip pain in patients undergoingtotal hip replacement / N.Q. Khan, S.T. Woolson //Orthopedics. - 1998. - Bd. 21. - S. 123 - 126.

287. Khosla et al. Incidence of Childhood Distal Forearm Fractures Over 30 Years: A Population-Based Study. //JAMA. 2003; 290: 1479-1485

288. Klee D. Surface modification of poly(vinylidenefluoride) to improve the osteoblast adhesion / D. Klee, Z. Ademovic, A. Bosserhoff, H. Hoecker, G. Maziolis, H.J. Erli // Biomaterials. - 2003 Sep; Vol.24, No21. - P. 3663-3670. PubMed PMID: 12818537.

289. Klimenov V.A., Tverdokhlebov S.I., Bolbasov E.N., Shesterikov E.V., Novikov V.A., and Volokitina T.L. Application of Atomic-Force Microscopy Methods for Testing the Surface Parameters of Coatings of Medical Implants // Russian Journal of Nondestructive Testing. - 2011. - V. 47. - N. 11. - P. 771-782. 
290. Krastman P, van den Bent RP, Krijnen P, Schipper IB. Two cannulated hip screws for femoral neck fractures: treatment of choice or asking for trouble? // Arch Orthop Trauma Surg. 2006 Jul;126(5):297-303. Epub 2006 Apr 21.

291. Kyle RF. Fractures of the femoral neck // Instr Course Lect. 2009;58:61-8.

292. Lal S.K. Variations of some plasma components after closed fractures / S.K. Lal, K.C. Jacob, O.N. Nagi, A.L. Annamalai, C.R. Nair // J Trauma. - 1976. - Mar; Vol. 16, No 3. - P. 206-211. PubMed PMID: 56453.

293. Langer R., Vacanti J.P. Tissue engineering // Science. - 1993. - Vol. 260. - P. 920-926.

294. Lascombes P. Embrochage centromedullaire elastique staible. - Elsevier, 2006. -321 p.

295. Lavernia, C. Thigh pain in primary total hip arthroplasty/ C. Lavernia, M. D'Apuzzo, V.

Hernandez, D. Lee //J. Arthroplasty. - 2004. - Vol. 19. - P.1208 - 1211.

296. Le Geros R.Z. Calcium phosphate-based osteoinductive materials // Chem. Rev. - 2008.

- Vol. 108 (11). - P. 4742-4753.

297. Lee S.H., Shin H. Matrices and scaffolds for delivery of bioactive molecules in bone and cartilage tissue engineering // Adv. Drug Deliv. Rev. - 2007. - V. 59. - P. 339-359.

298. Leeuwenburgh S.C.G., Wolke J.G.C., Lommen L. et al. Mechanical properties of porous, electrosprayed calcium phosphate coatings // J. Biomed. Mater. Res. - 2006. - Vol. 78. - P. $558-569$.

299. Liang J., Hu L., Hao J. Improvement of corrosion properties of microarc oxidation coating on magnesium alloy by optimizing current density parameters // Appl. Surf. Sci. 2007. - N. 253. - P. 6939-6945.

300. Liu X.; Chu P.K.; Ding C. Surface modification of titanium, titanium alloys, and related materials for biomedical applications.// Mater. Sci. Eng.: R. - 2004. - N. 47. - P. 49-121

301. Liu Y., de Groot K., Hunziker E.B. BMP-2 liberated from biomimetic implant coatings induces and sustains direct ossifi cation in an ectopic rat model // Bone. - 2005. - Vol. 36. P. 745-757.

302. Lukert B.P., Adams J.S. Calcium and phosphorus homeostasis in man. Effect of corticosteroids // Arch. Intern. Med. - 1976. - Vol. 136, № 11. - P. 1249-1253.

303. Luhmann SJ, Schootman M, Schoenecker PL, Dobbs MB, Gordon JE. Complications and Outcomes of Open Pediatric Forearm Fractures // J Pediatr Orthop , 2004, v. 24, 1, P. 1-6. $125-135$.

304. Lykke N, Lerud PJ, Strømsøe K, Thorngren KG. Fixation of fractures of the femoral neck. A prospective, randomised trial of three Ullevaal hip screws versus two Hansson hookpins // J Bone Joint Surg Br. 2003 Apr;85(3):426-30.

305. Marsh, J.L. External fixation of open humerus fractures / J.L. Marsh, C.R. Mahoney, D. Steinbronn // Iowa Orthop. J. - 1999. - Vol. 19. - P. 35-42.

306. Mathoulin C., Gilbert A., Judet H. et al. Free transfer of the vascularized fibula in pseudarthrosis and femoral bone loss // Rev. Chir. Orthop. Repar. Appar. Mot. - 1993. - Vol. 79, № 6. - P. 492-499.

307. Miller S.C. Ethane-1-hydroxy-1, 1-diphosphonate (EHDP). Effects on growth and modeling of the rat tibia / S.C. Miller, W.S. Jee // Calcif Tissue Res. - 1975. Sep 5; Vol.18, No 3. - P. 215-31. PubMed PMID: 810231.

308. Minato I. Treatment of femoral neck fracture--preference to internal fixation // Clin Calcium. 2011 Mar;21(3):474-6.

309. Minguell J.J., Martines J. Growth pattern and function of bone marrow fibroblasts from normal and lymphoblastic leukemia patients // Exp. Hematol. - 1983. - Vol. 11, № 6. - P. 522-526.

310. Mittal K.L. Adhesion measurement of films and coatings: a commentary // Adhesion Measurement of Films and Coatings. - Utrecht: VSP BV, 1993. - P. 1-13.

311. ModrzewsKi K., Urban T. Principles and results of treatment of forearm shaft fractures with Rush pins stabilization.// Chir. Narzadow Ruchu Orlop. Pol. 2000; 65 (1): 19-24.

312. Möllenhoff G, Walz M, Clasbrummel B, Muhr G. Femoral neck fracture. Osteosynthesis or which endoprosthesis is indicated? // . Orthopade. 2000 Apr;29(4):288-93. 
313. Monitorizacao da resposta organica ao trauma e a sepse / A. Basile-Filho, M. S. V. Marques, M. M. Auxiliadora et al. // Fac. med. Ribeirao Preto. Hosp. Clin. - 2001. - 34, № 1.-P.5-17.

314. Nelca V., Morosanu C., Iliescu M., Mihailescu I.N. Microstructure and mechanical properties of hydroxyapatite thin films grown by RF magnetron sputtering // Surface and Coatings Technology. - 2003. -V. 173. - N. 2. - P. 315-322.

315. Nicholls TP, Shoemaker WC, Wo CC, Gruen JP, Amar A, Dang AB. Survival, hemodynamics, and tissue oxygenation after head trauma. J Am Coll Surg. 2006 Jan;202(1):120-30. Epub 2005 Nov 10. PMID: 16377505.

316. Nishiguchi S Biology of alkali- and heat-treated titanium implants / Nishiguchi S, Fujibayashi S, Kim H M, Kokubo T, Nakamura T // J Biomed Mater Res.- 2003. - Vol. 67A. P. 26-35.

317. Oestern H.J. Tsherne H. Pathophysiology and classification of soft tissue damage in fractures. Orthopade 12:2, 1983.

318. Oksu G., Aktuglu K. Management of shotgun induced open fractures of the humerus with Ilizarov external fixator // Ulus Travma Derg. - 2005. - Vol. 11, № 1. - P. 23-28.

319. Oskam J, J Kingma, H J Klasen. Fracture of the Distal Forearm: Epidemiological

Developments in the Period 1971 -1995.- Injury, 1998, v. 29, P. 353-355.

320. Owens K., Wendt R.C. Estimation of the Surface Free Energy of Polymers // Journal of Applied Polymer Science. - 1969. - V. 13. - N. 8. - P. 1741-1747.

321. Oxidative stress after moderate to extensive burning in humans / A.M. Pintaudi, L. Tesoriere, N. D'Arpa et al. // Free Radic. Res. - 2000. - v. 33. - № 2. - P. 139-146.

322. Ozeki K., Yuhta T., Fukui Y., Aoki H. Phase composition of sputtered films from a hydroxyapatite target // Surface and Coatings Technology. - 2002. - V. 160. - P. 54-61.

323. Paley D., Maar D.C. Ilizarov bone transport treatment for tibial defects // J. Orthop. Trauma. - 2000. - Vol. 14, № 2. - P. 76-85.

324. Pape HC, Giannoudis PV, Krettek C, Trentz O. Timing of fixation of major fractures in blunt polytrauma: role of conventional indicators in clinical decision making. $\mathrm{J}$ Orthop Trauma. 2005 Sep;19(8):551-62.

325. Parfitt A.M. Renal function in treated hypoparathyroidism. A possible direct nephrotoxic effect of vitamin D // Adv. Exp. Med. Biol. - 1977. - Vol. 81. - P. 455-464.

326. Parfitt A.M. The cellular basis of bone turnover and bone loss: a rebuttal of the osteocytic resorption bone flow theory // Clin. Orthop. Relat. Res. - 1977. - Vol. 127. - P. 236-247.

327. Patterson S.P., Daffner R.H., Gallo R.A. Electrochemical corrosion of metal implants // AJR. Am. J. Roentgenol. - 2005. - N. 184. - P. 1219-1222.

328. Pauwels F. Der Schenkelhals-bruch, ein mechanisches Problem /F.Pauwels. - Stuttgart: Enke,1935- P.461.

329. Pavelka T. Complications of internal fixation by a short proximal femoral nail / $\mathrm{T}$.

Pavelka, J.Matejka, H.Cervenkova // Acta Chir. Orthop. Traumatol. Cech. 2005. Vol. 72, No 6. P. 344-354.

330. Pavolini, B. The Ilizarov fixator in trauma: a 10-year experience / B. Pavolini, M. Maritato, L. Turelli, M.

331. Perren S.M., Evoluthion of internal fixation of long bone fractures. The scientific basis of biological internal fixation: Choosing a new balance between stability and biology. J.Bone Joint Surg. Br. 84: 1093, 2002.

332. Perren S.M., Matter P. Evolution of AO philosophy. Acta Chir. Orthop. Traumatol. Cech. 70:205, 2003.

333. Pichugin V.F., Surmenev R.A., Shesterikov E.V., Ryabtseva M.A., Eshenko E.V., Tverdokhlebov S.I., Prymak O., Epple M. The preparation of calciumphosphate coatings on titanium and nickel-titanium by RF-magnetron-sputtered deposition: Composition, structure and micromechanical properties //Surface and Coatings Technology. - 2008 . - T. 202. C. 3913. 
334. Polyzois, V.D. Combined distraction osteogenesis and Papineau technique for an open fracture managementof the distal lower extremity / V.D. Polyzois [et al.] //Clin. Podiatr.

Med. Surg. - 2010. - Vol. 27, N 3. -P. 463-467.

335. Raaymakers EL, Schafroth M. Medial femoral neck fracture. Controversies in treatment // Unfallchirurg. 2002 Feb;105(2):178-86.

336. Raaymakers EL. Fractures of the femoral neck: a review and personal statement // Acta Chir Orthop Traumatol Cech. 2006;73(1):45-59.

337. Rama Krishna L.; Somaraju K.R.C.; Sundararajan G. The tribological performance of ultra-hard ceramic composite coatings obtained through microarc oxidation // Surf. Coat.

Tech. - 2003. - N. 163-164. - P. 484-490.

338. Reddi A.H. Role of morphogenetic proteins in skeletal tissue engineering and regeneration // Nat. Biotechnol. - 1998. - Vol. 16, № 3. - P. 247-252.

339. Rehm M, Conzen PF, Peter K, Finsterer U. Das Stewart-Modell. «Moderner» Ansatz zur Interpretation des Säure-Basen-Haushalts// Anaesthesist. 2004 Apr;53(4):347-357.

340. Reynders, P. Open acute segmental tibial fracture fixation using the Less Invasive Stabilisation System (LISS): study of 23 consecutive cases / P. Reynders [etal.] // Injury. 2009. - Vol. 40, N 4. - P. 449-454.

341. Ribeiro C, Sencadas V, Correia DM, Lanceros-Méndez S. Piezoelectric polymers as biomaterials for tissue engineering applications. Colloids Surf B Biointerfaces. 2015 Dec 1;136:46-55. doi: 10.1016/j.colsurfb.2015.08.043.

342. Ripamonti U., Crooks J., Khoali L., Roden L. The induction of bone formation by coral-derived calcium carbonate/hydroxyapatite constructs // Biomaterials. - 2009. - Vol. 30, № 7. - P. 1428-1439.

343. Rivera E.M., Araiza M., Brostow W. et al. Synthesis of hydroxyapatite from eggshells // Matter. Lett. - 1999. - Vol. 41. - P. 128-134.

344. Rogmark C, Carlsson A, Johnell O, Sernbo I. A prospective randomised trial of internal fixation versus arthroplasty for displaced fractures of the neck of the femur. Functional outcome for 450 patients at two years // J Bone Joint Surg Br. 2002 Mar;84(2):183-8.

345. Rohanizadeh R., LeGeros R.Z., Harsono M., Bendavid A. Adherent apatite coating on titanium substrate using chemical deposition // J. Biomed. Mater. Res. - 2005. - Vol. 72. - P. $428-438$.

346. Ronzoni, G. Hormonal and metabolic response to trauma: physiopathology and therapeutic management / G. Ronzoni, F. Carli // Minerva anaesthesiol. - 1992. - Vol. 58. -№ 6. - P. 323 - 346.

347. Ronzoni, G. Hormonal and metabolic response to trauma: physiopathology and therapeutic management / G. Ronzoni, F. Carli // Minerva anaesthesiol. - 1992. - Vol. 58. -№ 6. - P. $323-346$.

348. Rossnagel S.M. Sputter Deposition. In: Sproul W.D., Legg K.O., editors / Opportunities for Innovation: Advanced Surface Engineering. - Switzerland: Technomic Publishing Co., 1995.

349. Roy, K. Evaluation of glutatione and ascorbic acid as supressors of drug-induced lipid peroxidation / K. Roy, A. U. De, C Sengupta // Indian J. Exp. Biol. - 2000. - 38, № 6. -P. 580-586.

350. Ryabchikov A.I., Stepanov I.B. Equipment and methods for hybrid technologies of ion beam and plasma surface materials modification // Surface and Coating Technology. - 2009. - V. 203. - № 17/18. - P. 2784-2787.

351. S. Peterson. Травма верхней конечности/ S. Peterson, T. R. Lehman //Травма: в 3 т./ под ред. Дэвида В. Феличано, Кеннэта Л. Маттокса, Эрнеста Е. Мура ; пер. с англ. под ред. Л. А. Якимова, Н. Л. Матвеева. - М.: Изд-во Панфилова ; Бином, 2013. - Т. 2, гл. 42. - С. 1073-1119.

352. Saarenpää I., Heikkinen T., Partanen J., Jalovaara P. Hip fracture treatment in Oulu oneyear survey with four-month follow-up // Scand. J. Surg. - 2006. - Vol. 95, № 1. - P. 61-67. 
353. Scalea TM, Boswell SA, Scott JD, Mitchell KA, Kramer ME, Pollak AN. External fixation as a bridge to intramedullary nailing for patients with multiple injuries and with femur fractures: damage control orthopedics. J Trauma. 2000 Apr;48(4):613-21; discussion 621-3

354. Scannell, B.P. Skeletal traction versus external fixation in the initial temporization of femoral shaft fractures in severely injured patients / B.P. Scannell [et al.] // J.Trauma. - 2010. - Vol. 68, N 3. - P. 633-640.

355. Schmidt AH, Asnis SE, Haidukewych G, Koval KJ, Thorngren KG. Femoral neck fractures // Instr Course Lect. 2005;54:417-45.

356. Serum cholesterol, uric acid and cholinesterase in victims of the Tokyo subway sarin poisoning: a relation with post-traumatic stress disorder / M. Tochigi, T. Umekage, T. Otani et al. // Neuro. sci. Res. - 2002. - v. 44. - № 3. - P. 267-272.

357. Serum lactate, not base deficit, rapidly predicts survival after major burns / J.C. Jeng, K. Jablonski, A. Bridgeman et al. // Burns. - 2002. - v. 28. - № 2. - P. 161-166.

358. Seyfettinoğlu F, Ersan O, Kovalak E, Duygun F, Ozsar B, Ateş Y. Fixation of femoral neck fractures with three screws: results and complications // Acta Orthop Traumatol Turc. 2011;45(1):6-13. doi: 10.3944/AOTT.2011.2434.

359. Shiogai T, Nara I, Saruta K, Hara M, Saito I. Continuous monitoring of cerebrospinal fluid acid-base balance and oxygen metabolism in patients with severe head injury: pathophysiology and treatments for cerebral acidosis and ischemia.Acta Neurochir Suppl. 1999;75:49-55. PMID: 10635377 [PubMed - indexed for MEDLINE].

360. Sinikumpu JJ, Serlo W. The shaft fractures of the radius and ulna in children: current concepts. J Pediatr Orthop B. 2015 May;24(3):200-6.

361. Skála-Rosenbaum J, Dzupa V, Bartonícek J, Dousa P, Pazdírek P. Osteosynthesis of intracapsular femoral neck fractures // Rozhl Chir. 2005 Jun;84(6):291-8

362. Smektala R, Wenning M, Ekkernkamp A. Femoral neck fracture in the younger patient. Contrast between guideline and management reality--results of external quality assurance in 1,747 follow-up cases // Unfallchirurg. 2001 Sep;104(9):820-6.

363. Smith W. R. Травма нижней конечности/ W. R. Smith, P. F. Stahel, S. J. Morgan, P. G. Trafton //Травма: в 3 т./ под ред. Дэвида В. Феличано, Кеннэта Л. Маттокса, Эрнеста Е. Мура ; пер. с англ. под ред. Л. А. Якимова, Н. Л. Матвеева. - М.: Изд-во Панфилова ; Бином, 2013. - Т. 2, гл. 43. - С. 1121-1162.

364. Søballe K., Hansen E.S., Brockstedt-Rasmussen H.B., Bünger C. Hydroxyapatite coating converts fibrous tissue to bone around loaded implants // J. Bone Jt Surg. 1993. - Vol. 75. - P. 270-278.

365. Søballe K., Hansen E.S., Brockstedt-Rasmussen H.B. et al. Gap healing enhanced by hydroxyapatite coatings in dogs // Clin. Orthop. - 1991. - Vol. 272. P. 300-307.

366. Søballe K., Overgaard S. The current status of hydroxyapatite coating of prostheses // J. Bone Jt Surg. (Br). - 1996. - Vol. 78. - P. 689-691.

367. Sokół G, Snela S, Piasek R. Final results of the operatively treated femoral neck fractures in children and adolescents // Chir Narzadow Ruchu Ortop Pol. 2010 Sep-Oct;75(5):300-4.

368. Sommer C., Bereiter H., Actual relevance jf minimal invasive surgery in fracture treatment. Ther Umsch 62:145, 2005.

369. Spector M. Basis Principles of Tissue Engineering in Tissue Engineering Application in Maxillofacial Surgery and Periodontics; Ed. S. Lynch. - Quintessence Publishing Co. Inc., 1999. - P. 3-17.

370. Steinmann P.A., Tardy Y., Hintermann H.E. Adhesion testing by the scratch method: the influence of intrinsic and extrinsic parameters on the critical load // Thin Solid Films. - 1987. - Vol. 154. - P. 333-349.

371. Stephenson P.K., Freeman M.A.R., Revell P.A. et al. The effect of hydroxyapatite coating on ingrowth of bone into cavities in an implant // J. Arthropl. - 1991. - Vol. 6. - P. 51-58. 
372. Su H, Aharonoff GB, Zuckerman JD, Egol KA, Koval KJ. The relation between discharge hemoglobin and outcome after hip fracture.Am J Orthop. 2004 Nov;33(11):576-80

373. Suchanek W., Yoshimura M. Processing and properties of hydroxyapatite-based biomaterials for use as hard tissue replacement implants // J. Mater.Res. - 1998. - Vol. 13, Iss. 1. - P. 94-117.

374. Suzuki, T. Safety and efficacy of conversion from external fixation to plate fixation in humeral shaft fractures / T. Suzuki [et al.] // J. Orthop. Trauma. - 2010. - Vol. 24, N 7. - P. 414-419.

375.Takemoto M Bone-bonding ability of a hydroxyapatite coated zirconia-alumina nanocomposite with a microporous surface / Takemoto M., Fujibayashi S., Neo M. et al. // J. Biomed. Mater. Res. - 2006. - Vol. 78. P. 693-701.

376.Thomas K.A., Cook C.D., Ray R.J., Jarcho M. Biologic response to hydroxylapatite coated titanium hips // J. Arthropl. - 1989. - Vol. 4. - P. 43-53.

377.Tripon P., Dalzotto G., Poichotte A. et al. Reconstruction of post-traumatic diaphyseal bone loss by segmental bone transfer // Ann. Chir. Plast. Esthet. - 2000. - Vol. 45, № 3. - P. 336345.

378. Tscherne H. Principles of primery treatment of fractures with soft tissue injury. Orthopade 12:9, 1983.

379. Tu Y.K., Yen C.Y., Yeh W.L. et al. Reconstruction of posttraumatic long bone defect with free vascularized bone graft: good outcome in 48 patients with 6 years' follow-up // Acta Orthop. Scand. - 2001. - Vol. 72, № 4. - P. 359-364.

380. Tucker, H.L. Management of unstable open and closed tibial fractures using the Ilizarov method / H.L. Tucker, J.C. Kendra, T.E. Kinnebrew //Clin. Orthop. -1992.-N 280. -P. 125135

381. Tverdokhlebov S.I., Bolbasov E.N., Shesterikov E.V., Malchikhina A.I., Novikov V.A., Anissimov Y.G. Research of the surface properties of the thermoplastic copolymer of Vinilidene Fluoride and Tetrafluoroethylene modified with radio-frequency magnetron sputtering for medical application // Applied Surface Science. - 2012. - V. 263 - P. 187194.

382. Tverdokhlebov S.I., Ignatov V.P., Stepanov I.B., Sivin D.O., Petlin D.G. Hybrid Method for the Formation of Biocomposites on the Surface of Stainless Steel Implants // Engineering - 2012. -V 4. - P 613-618.

383. Van der Wal E., Vredenberg A.M., Ter Brugge P.J., Wolke J.G.C. and Jansen J.A. The in vitro behavior of as prepared and pre-immersed RF-sputtered calcium phosphate thin films in a rat bone marrow cell model // Biomaterials. - 2006. - N. 27. - P. 1333-1340.

384. Van Dijk K., Schaeken H.G., Wolke J.G.C., de Groot K., Jansen J.A. Influence of discharge power level on the properties of hydroxyapatite-films deposited on Ti6A14V with RF magnetron sputtering // J. of Biomedical Materials Research. - 1995. - V. 29. - N. 2. P. 269-276.

385. Vidal J. et al. Fixation externe: "a la recherche de la meilleure stabilite" - Apres 17 ans d'experience // Rev. Chir. Orthop. - 1983. - Vol. 69, N 5. - P. 372-375.

386. Volume replacement in trauma patients within the first $24 \mathrm{~h}$ and its impact on the interpretation of biochemical data / F. Gebhard, C. Riepl, U.C. Liener et al. // Langenbecks Arch. Surg. - 2000. - v. 385. - № 6. - P. 406-411.

387. Wang X.X., Wang X., Li Z.L. Effects of mandibular distraction osteogenesis on the inferior alveolar nerve: An experimental study in monkeys // Plast. Reconstr. Surg. - 2002. V. 109. - № 7. - P. 2373-2383.

388. Wang J., Layrolle P., Stigter M., de Groot K. Biomimetic and electrolytic calcium phosphate coatings on titanium alloy: physicochemical characteristics and cell attachment // Biomaterials. - 2004. - Vol. 25. - P. 583-592.

389. Weng J., Liu Q., Wolke J., Zhang D., De Groot K. The role of amorphous phase in nucleating bone-like apatite on plasma-sprayed hydroxyapatite coatings in simulated body fluid // J. Mater. Sci. Lett. - 1997. - N. 16. - P. 335-337.

390. Williams D.F. Corrosion of Implant Materials // Ann. Rev. Mater. Sci. - 1992. - Vol. 6. - P. 237-266. 
391. Windolf M, Braunstein V, Dutoit C, Schwieger K. Is a helical shaped implant a superior alternative to the Dynamic Hip Screw for unstable femoral neck fractures? A biomechanical investigation // Clin Biomech (Bristol, Avon). 2009 Jan;24(1):59-64. Epub 2008 Oct 31.

392. Wolke J.G.C., de Blieck-Hogervorst J.M.A., Dhert W.J.A., Klein C.P.A.T., de Groot K. Studies on the thermal spraying of apatite bioceramics //J. Thermal Spray Technol. - 1992. N. 1. - P. 75-82.

393. Wu T.W. Microscratch and load relaxation tests for ultra-thin films // J. Mater. Res. 1991. - Vol. 6. - P. 407-426.

394. Yamakawa M Katou T Ai ima K Yanagawa M Kama-mura J Potassium oxalate the factor of the nephrolytiasis //Acta Urol Jap — 2004 — Vol 37 № 10—P 1111-1114.

395. Yang Y., Kim K.-H. and Ong J.L. A review on calcium phosphate coatings produced using a sputtering process--an alternative to plasma spraying // Biomaterials. - 2005. - V. 26. - N. 3. - P. 327-337.

396. Yannas I.V., Hansbrough J., Ehrlich N. What criteria should be used for designing artificial skin replacements and how well do the current grafting materials meet these criteria? // J. Trauma. - 1984. - Vol. 24. - P. 29.

397. Yonggang Yan, Wolke J.G.C., Yubao Li and Jansen J.A. The influence of discharge power and heat treatment on calcium phosphate coatings prepared by RF magnetron sputtering deposition // J. Mater. Sci.: Mater. Med. - 2007 - V. 18. - N. 6. - P. 1061-1069.

398. Yoshinari M., Hayakawa T., Wolke J.G.C., Nemoto K., Jansen J.A. Influence of rapid heating with infrared radiation on RF magnetron-sputtered calcium phosphate coatings // Journal of biomedical materials research. - 1997. - V. 37. - N 1. - P. 60-67.

399. Yuan H., de Bruijn J.D., Li Y. et al. Bone formation induced by calcium phosphate ceramics in soft tissue of dogs: a comparative study between $\alpha$-TCР и $\beta$-TCP // J. Mater. Sci. Mater. Med. - 2001. - Vol. 12. - P. 7-13.

400. Yung S. H., Lam C. Y. Percutaneous intramedullary Kirschner wiring for displaced diaphyseal forearm fractures in children.// J. Bone Jt, Surgery, Br. 1998. Jan;80(1): 91-4.

401. Zhou J, Dang Y, Zhang PX, Wang J, Fu ZG, Zhang DY, Wang TB, Xu HL, Xue F, Chen JH, Yang M, Wang G, Shen HL, Wang GL, Wu X-, Jiang BG. Analysis of function and related impact factors after operation of femoral neck fracture for patients aged less than sixty years // Beijing Da Xue Xue Bao. 2011 Oct 18;43(5):703-6.

402. Ziv V., Weiner S. Bone crystal sizes - a comparison of transmission electron-microscopic and X-raydiffraction line-width broadening techniques // Conn. Tiss. Res. - 1994. - Vol. 30. - P. 165-175. 